Hydrogeology and Potential Effects of Changes in Water Use, Carson Desert Agricultural Area, Churchill County, Nevada

UNITED STATES GEOLOGICAL SURVEY

Open-File Report 93-463

Prepared in cooperation with the BUREAU OF RECLAMATION

QE

75.

U58 of no.93-463

1994

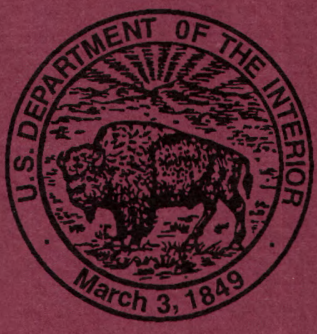

Carson City, Nevada 1994 

Hydrogeology and Potential Effects of Changes in Water Use, Carson Desert Agricultural Area, Churchill County, Nevada

By Douglas K. Maurer, Ann K. Johnson, and Alan H. Welch

UNITED STATES GEOLOGICAL SURVEY

Open-File Report 93-463

Prepared in cooperation with the

BUREAU OF RECLAMATION

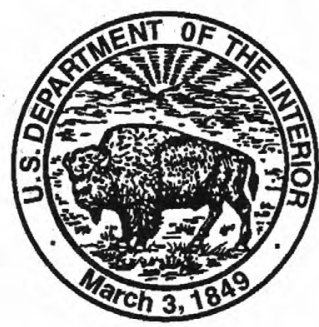




\section{U.S. DEPARTMENT OF THE INTERIOR \\ BRUCE BABBITT, Secretary}

U.S. GEOLOGICAL SURVEY

Robert M. Hirsch, Acting Director

For additional information write to:

\section{District Chief}

U.S. Geological Survey

333 W. Nye Lane, Room 203

Carson City, NV 89706-0866
Copies of this report may be purchased from:

U.S. Geological Survey

Earth Science Information Center

Open-File Reports Services

Federal Center, MS 517

Box 25286

Denver, CO 80225-0046 


\section{CONTENTS}

Glossary of Selected Terms $\ldots \ldots \ldots \ldots \ldots \ldots \ldots \ldots \ldots \ldots \ldots \ldots \ldots \ldots \ldots \ldots \ldots \ldots \ldots \ldots$ vii

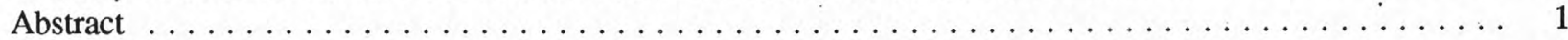

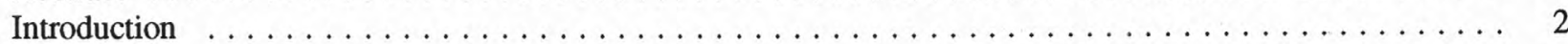

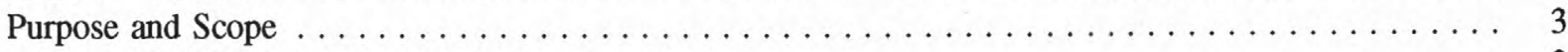

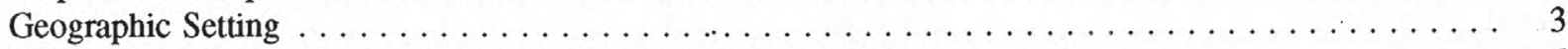

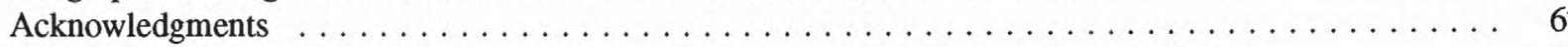

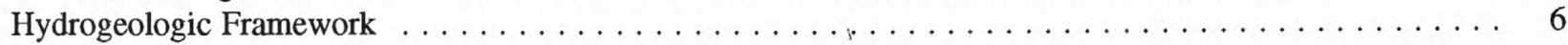

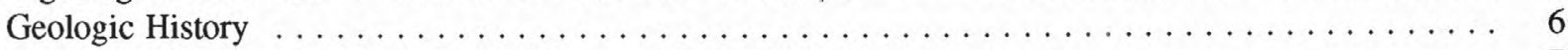

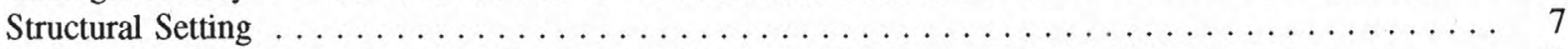

Description and Distribution of Hydrogeologic Units $\ldots \ldots \ldots \ldots \ldots \ldots \ldots \ldots \ldots \ldots$

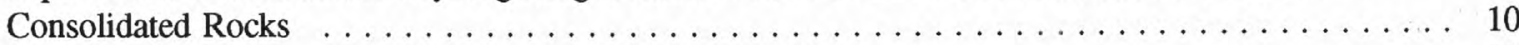

Semiconsolidated and Unconsolidated Sediments $\ldots \ldots \ldots \ldots \ldots \ldots \ldots \ldots \ldots \ldots \ldots$

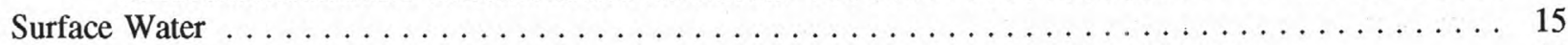

Description of Surface-Water Flow System $\ldots \ldots \ldots \ldots \ldots \ldots \ldots \ldots \ldots \ldots \ldots \ldots \ldots \ldots$

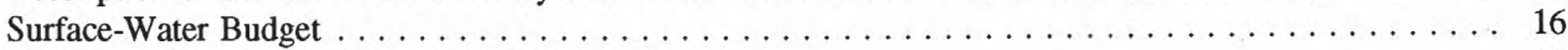

Factors that Affect Estimates of Flow Volumes $\ldots \ldots \ldots \ldots \ldots \ldots \ldots \ldots \ldots \ldots \ldots \ldots$

Estimates of Historical Surface-Water Flow Volumes $\ldots \ldots \ldots \ldots \ldots \ldots \ldots \ldots \ldots \ldots$

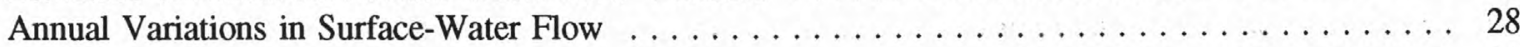

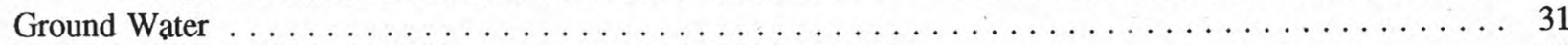

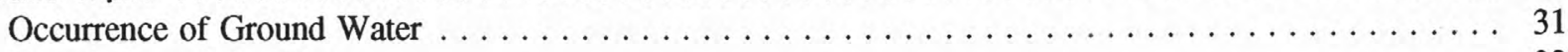

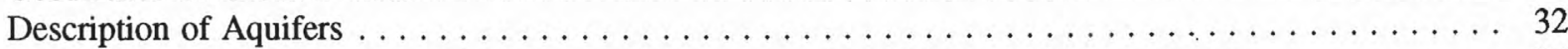

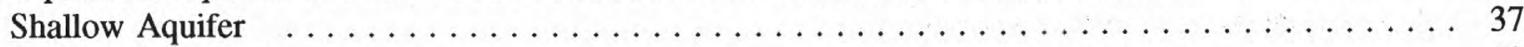

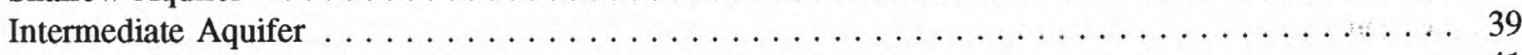

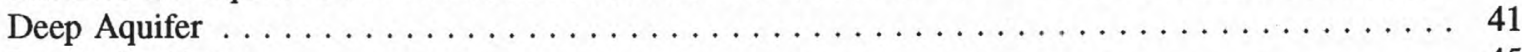

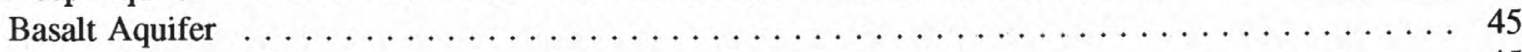

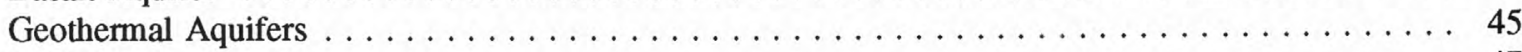

Water Quality . . . . . . . . . . . . . . . . . . . . . . . . . . . . . . 47

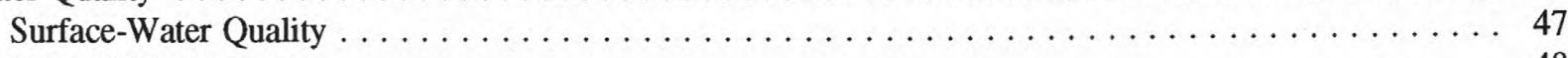

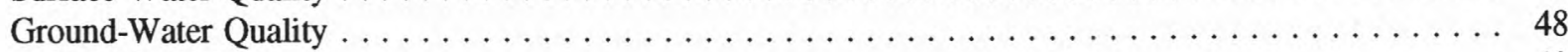

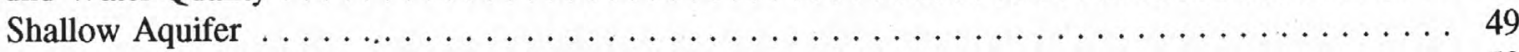

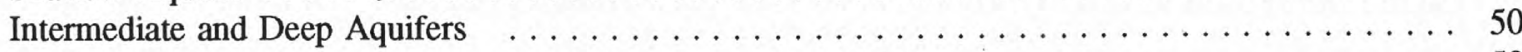

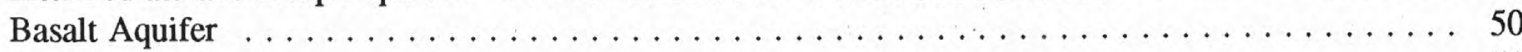

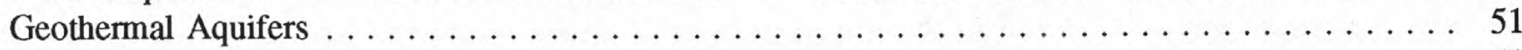

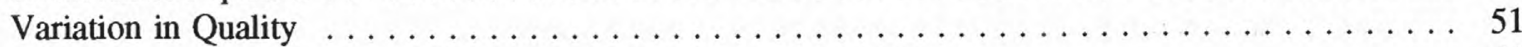

Display of Water-Quality Data and Statistical Analysis $\ldots \ldots \ldots \ldots \ldots \ldots \ldots \ldots \ldots \ldots$

Comparison of Present-Day Water Quality in the Hydrologic Zones . . . . . . . . . . . 56

Water Quality Before and After Widespread Project Irrigation Began $\ldots \ldots \ldots \ldots \ldots \ldots \ldots$

Water Quality in the Shallow and Intermediate Aquifers $\ldots \ldots \ldots \ldots \ldots \ldots \ldots \ldots$

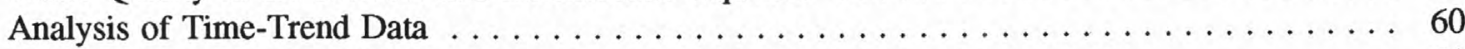

Discussion of Statistical Comparisons $\ldots \ldots \ldots \ldots \ldots \ldots \ldots \ldots \ldots \ldots \ldots \ldots \ldots$

Water Budget for Carson Desert $\ldots \ldots \ldots \ldots \ldots \ldots \ldots \ldots \ldots \ldots \ldots \ldots \ldots \ldots \ldots \ldots \ldots$

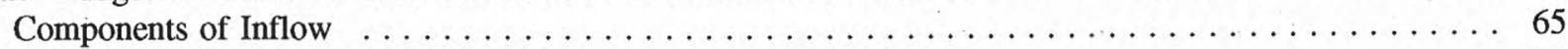

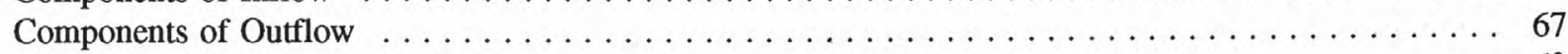

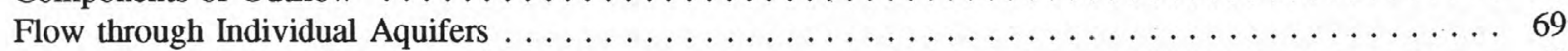

Qualitative Evidence . . . . . . . . . . . . . . . . . . . . . . . . 69

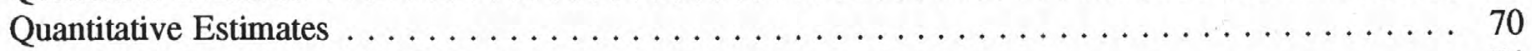

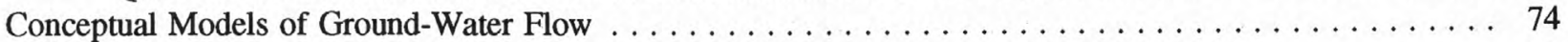

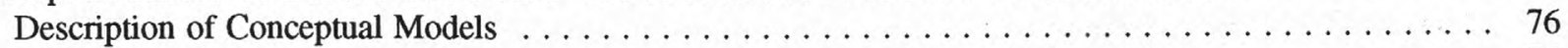

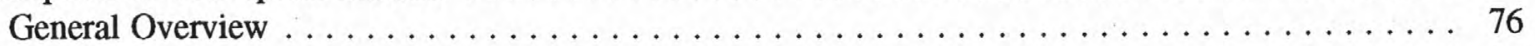

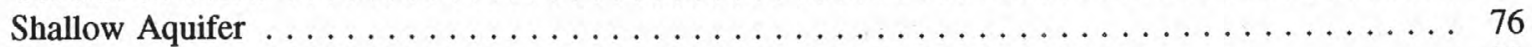

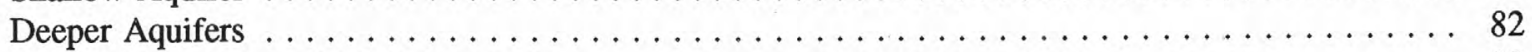

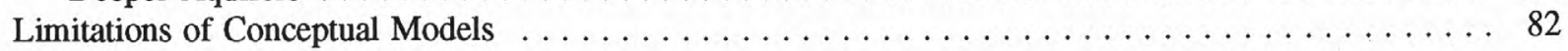


Potential Effects of Changes in Agricultural Water Use $\ldots \ldots \ldots \ldots \ldots \ldots \ldots \ldots \ldots \ldots \ldots$

Changes from 1988 Operating Criteria and Procedures $\ldots \ldots \ldots \ldots \ldots \ldots \ldots \ldots \ldots \ldots$

Changes from Water-Rights Acquisition Program and 75-Percent Project Efficiency . . . . . . 85

Suggestions for Future Study $\ldots \ldots \ldots \ldots \ldots \ldots \ldots \ldots \ldots \ldots \ldots \ldots \ldots \ldots \ldots$

Existing Water Resources and Ground-Water Movement $\ldots \ldots \ldots \ldots \ldots \ldots \ldots \ldots \ldots$

Potential Effects of Changes in Water Use $\ldots \ldots \ldots \ldots \ldots \ldots \ldots \ldots \ldots \ldots \ldots \ldots$

Summary and Conclusions $\ldots \ldots \ldots \ldots \ldots \ldots \ldots \ldots \ldots \ldots \ldots \ldots \ldots \ldots \ldots$

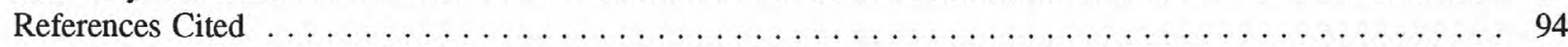

\section{PLATES}

[Plates in back pocket]

1. Map showing generalized geology of Carson Desert hydrographic area

2. Geologic sections across Carson Desert

3. Map showing distribution and relative permeability of late Quaternary geologic units and late Quaternary channels of ancestral Carson River, southern Carson Desert

\section{FIGURES}

1. Map showing discharging playas, phreatophytes, and irrigated land in Carson Desert hydrographic

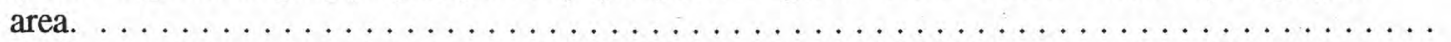

2. Map showing faults and depth to top of consolidated rocks of Mesozoic age, northern Carson Desert, as inferred from seismic and gravity surveys. . . . . . . . . . . . . . . . .

3. Schematic geologic section showing relation between sedimentary deposits of Quaternary age in

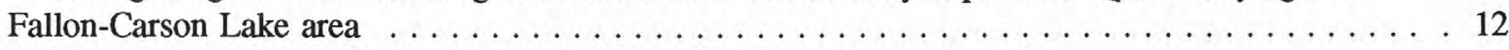

4. Diagram showing historical distribution of surface water in Carson Division. . . . . . . . . 20

5-7. Graphs showing:

5. Headgate deliveries as function of releases from Lahontan Reservoir. . . . . . . . . . .

6. Loss above farm headgates and outflow from irrigated lands as function of releases from Lahontan Reservoir. . . . . . . . . . . . . . . . . . . . . . . .

7. Outflow from irrigated lands as function of loss above farm headgates. . . . . . . . . .

8-12. Maps showing:

8. Depth to shallow ground water in 1904 and $1992 \ldots \ldots \ldots \ldots \ldots \ldots \ldots \ldots \ldots \ldots$

9. Depth to seasonal high water table and available water-holding capacity of soils. . . . . . . 36

10. Water-level altitude and general direction of ground-water flow in shallow aquifer. . . . . . . 38

11. Wells drilled in intermediate aquifer since 1985, grouped on basis of depth of open interval. . . 42

12. Areal extent of basalt aquifer and directions of vertical gradient among shallow, intermediate,

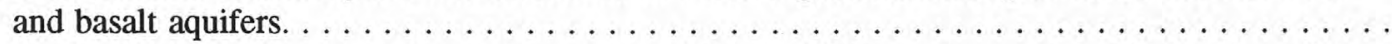

13. Hydrograph showing water-level fluctuations from 1971 to 1992 in well completed in basalt aquifer. .

14. Graph showing relations among head decline, total recharge, pumping-induced recharge, natural discharge, and pumpage from basalt aquifer. . . . . . . . . . . . . . . . . .

15. Map showing extent of four hydrologic zones and wells sampled-in shallow aquifer before widespread irrigation began and in shallow and intermediate aquifers after about 1975 . . . . . .

16. Graphs showing summary statistics for concentrations of dissolved solids and constituents in ground water of shallow aquifer beneath four hydrologic zones after about $1975 \ldots \ldots \ldots \ldots$. .

17. Map-view diagram showing differences in ground-water quality within shallow aquifer beneath four

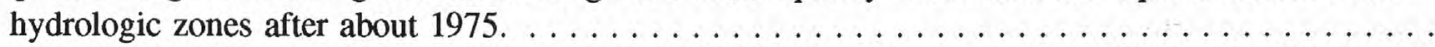

18. Graphs showing summary statistics for concentrations of chloride, sulfate, and dissolved solids in ground water of shallow aquifer beneath four hydrologic zones before widespread

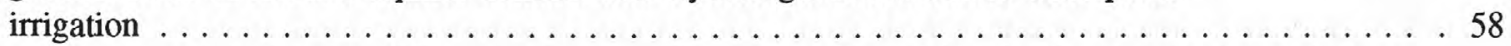

19. Map-view diagram showing differences in ground-water quality within shallow aquifer beneath four hydrologic zones before widespread irrigation began $\ldots \ldots \ldots \ldots \ldots \ldots \ldots \ldots \ldots$

38

20. Graphs showing summary statistics for concentrations of chloride, sulfate, and dissolved solids in ground water of shallow aquifer beneath lateral-flow/irrigated zone and discharge/irrigated zone before and after widespread irrigation began. . . . . . . . . . . . . . . . . 
21. Graphs showing summary statistics for concentrations of dissolved solids and constituents in ground water of shallow and intermediate aquifers beneath lateral-flow/non-irrigated zone, lateral-flow/irrigated zone, and discharge/non-irrigated zone after about 1975

22. Cross-sectional diagram showing differences in ground-water quality between shallow and intermediate aquifers beneath four hydrologic zones after about 1975

23. Map-view diagram showing differences in ground-water quality within intermediate aquifer beneath four hydrologic zones after about $1975 \ldots \ldots \ldots \ldots \ldots \ldots \ldots \ldots \ldots$

24. Graphs showing chloride concentrations in ground water from three wells tapping basalt aquifer. . . . 65

25. Diagram showing estimated recharge to, discharge from, and lateral flow within shallow, intermediate, and basalt aquifers $\ldots \ldots \ldots \ldots \ldots \ldots \ldots \ldots \ldots \ldots \ldots \ldots \ldots$

26. Schematic oblique view of conceptualized ground-water flow paths and sources of inflow

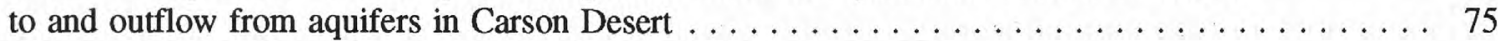

27-29. Schematic oblique views of conceptualized ground-water flow paths:

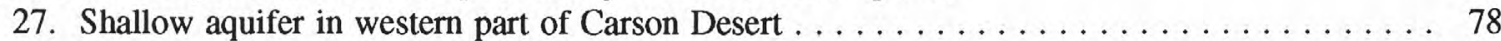

28. Shallow aquifer in central part of Carson Desert $\ldots \ldots \ldots \ldots \ldots \ldots \ldots \ldots \ldots$

29. Shallow and intermediate aquifers in eastern part of Carson Desert . . . . . . . . . 81

\section{TABLES}

1. Measured and estimated surface-water flows in Carson Division of Newlands Project, $1975-92 \ldots$. . . . . 18

2. Surface-water budget for Carson Division of Newlands Project $\ldots \ldots \ldots \ldots \ldots \ldots \ldots \ldots \ldots \ldots$

3. Estimates of inflow to and outflow from Carson Desert $\ldots \ldots \ldots \ldots \ldots \ldots \ldots \ldots \ldots \ldots \ldots \ldots$

4. Estimated annual precipitation and potential ground-water recharge in Carson Desert $\ldots \ldots \ldots \ldots 7$ 


\begin{tabular}{rll}
\hline Multiply & By & To obtain \\
acre-foot (acre- $\mathrm{ft})$ & 1,223 & square hectometer \\
cubic meter & cubic meter per square hectometer \\
acre-foot per acre (acre-ft/acre) & 3.022 & cubic hectometer per day \\
acre-foot per day (acre-ft/d) & 0.001233 & cubic hectometer per year \\
acre-foot per year (acre-ft/yr) & 0.001233 & cubic meter \\
cubic foot $\left(\mathrm{ft}^{3}\right)$ & 0.02832 & cubic meter per second \\
cubic foot per second $\left(\mathrm{ft}^{3} / \mathrm{s}\right)$ & 0.02832 & cubic meter per second per kilometer \\
foot $(\mathrm{ft})$ & 0.01760 & meter \\
cubic foot per second per mile $\left(\left(\mathrm{ft}^{3} / \mathrm{s}\right) / \mathrm{mi}\right)$ & 0.3048 & meter per day \\
foot per day $(\mathrm{ft} / \mathrm{d})$ & 0.3048 & meter per kilometer \\
foot per mile $(\mathrm{ft} / \mathrm{mi})$ & 0.1894 & meter per year \\
foot per year $(\mathrm{ft} / \mathrm{yr})$ & 0.3048 & liter per second \\
gallon per minute $(\mathrm{gal} / \mathrm{min})$ & 0.06309 & centimeter \\
inch $(\mathrm{in})$. & 2.540 & centimeter per year \\
inch per year $(\mathrm{in} / \mathrm{yr})$ & 2.540 & kilometer \\
mile $(\mathrm{mi})$ & 1.609 & square meter per day \\
square foot per day $(\mathrm{ft} / \mathrm{d})$ & 0.09290 & square kilometer \\
square mile $\left(\mathrm{mi}{ }^{2}\right)$ & 2.590 & metric ton per square hectometer \\
ton per acre (ton $/ \mathrm{acre})$ & 2.242 & metric ton per day \\
ton per day (ton/d) & 0.9072 &
\end{tabular}

For temperature, degrees Celsius $\left({ }^{\circ} \mathrm{C}\right)$ may be converted to degrees Fahrenheit $\left({ }^{\circ} \mathrm{F}\right)$ by using the formula $\left.{ }^{\circ} \mathrm{F}=\left[1.8\left({ }^{\circ} \mathrm{C}\right)\right]+32\right]$

\section{Abbreviated Water-Quality Units Used in this Report}

$\mu \mathrm{g} / \mathrm{L}$ (microgram per liter) $\mathrm{mg} / \mathrm{L}$ (milligram per liter)

\section{Vertical Datum}

In this report, "sea level" refers to the National Geodetic Vertical Datum of 1929 (NGVD of 1929, formerly called "Sea-Level Datum of 1929"), which is derived from a general adjustment of the first-order leveling networks of the United States and Canada. 


\section{GLOSSARY OF SELECTED TERMS}

The following definitions are from Lohman and others (1972), American Geological Institute (1976), Hillel (1980), Bates and Jackson (1984; 1987), Johnson (1988), and other sources.

Aquifer - A formation, group of formations, or part of formation that contains sufficient saturated permeable material to yield significant quantities of water to wells or springs.

Available water-holding capacity - Difference between amount of water in soil at field capacity (saturation) and amount at wilting point; also capacity of soil to hold water available for use by most plants.

Bench/bottom land - A designation that determines the maximum allowable water delivery to irrigable, waterrighted lands according to the Alpine Decree. Bench lands have soils with an available water-holding capacity of less than 8 inches, with a seasonal high water table of greater than 5 feet below land surface, and are allowed annual diversion of 4.5 acre-foot per acre. Bottom lands have soils with an available water-holding capacity of greater than or equal to 8 inches, with a seasonal high water table of less than or equal to 5 feet below land surface, and are allowed an annual diversion of 3.5 acre-ft/acre (Bureau of Reclamation, 1992a, p. 7).

Central tendency - In statistics, measures of central tendency describe distribution in terms of central value. In nonparametric statistics, median is central value.

Confined ground water - Ground water that is under pressure significantly greater than atmospheric. Wells tapping confined ground-water systems commonly flow without pumping.

Consumptive use - Net amount of water consumed by vegetation.

Discharging playa - Ephemeral lake bed where water table is sufficiently shallow to allow ground-water discharge to atmosphere.

Eolian - Said of deposits, such as sand, that are arranged or formed by wind.

Extension - Expansion, or stretching of the Earth's crust. For example, an area originally 50 miles wide that undergoes 100-percent extension becomes 100 miles wide.

Facies - Mappable, aerially restricted rock body, differing in lithology or fossil content from other beds deposited at the same time and in lithologic continuity.

Felsic - Said of igneous rock having abundant light-colored minerals, such as feldspar and silica (quartz). Examples of felsic rocks: rhyolite and granite.

Formation - Primary unit of formal geologic mapping. Body of rock that has certain distinctive lithic characteristics and that either is identifiable also by stratigraphic position or is distinctly mappable. Formations may be combined together into groups or subdivided into members and may contain more than one facies.

Head - Height, above standard datum, of the surface of a column of water that can be supported by static pressure at a given point; a measure of fluid potential at a given point; or an altitude of standing water level in a well.

Hydraulic gradient - Change in head, water level, or stream stage with distance, in either a vertical or horizontal direction.

Hydraulic conductivity - Volume of water that will move in a unit time under a unit hydraulic gradient through a unit area of aquifer material at right angles to the direction of flow. 
Isostatic rebound - Upward equilibrium adjustment of land surface after removal of a large mass, such as 500foot-deep ancient Lake Lahontan.

ka - Thousand years ago.

Lysimeter - Generally a large tank of soil set in field to represent prevailing soil and climatic conditions and allow more accurate measurement of physical processes than can be determined in the open field. Water inflow, water level, and soil moisture can be closely monitored in a lysimeter, which generally contains the growing crop. A lysimeter provides reliable measurements only when soil or above-ground conditions do not markedly differ from those of the field itself.

Ma - Million years ago.

Mafic - Said of igneous rock composed of ferromagnesian, dark-colored minerals. Relatively rich in iron, magnesium, and calcium. Examples of mafic rocks: basalt, gabbro.

Newlands Project area - Includes irrigated lands of both the Truckee Division, which are irrigated with flow from the Truckee River, and the Carson Division, which are irrigated with flow released from Lahontan Reservoir. The Project uses water stored and transmitted along the channels of the Carson and Truckee Rivers and the Truckee Canal.

Nonparametric tests - Statistical tests that do not assume data have a particular distribution. These tests use ranked data rather than original data values. These tests are also called "distribution-free."

OCAP - Acronym for Operating Criteria and Procedures for the Newlands Project.

On-farm loss - Volume of water delivered to farm headgates that does not supply consumptive use.

Operational spill - Water lost from the surface-water distribution system during delivery for irrigation.

Parametric tests - Statistical tests that assume data have a specific distribution.

Permeability (permeable) - Measure of relative ease with which porous medium can transmit liquid under a hydraulic gradient.

Phreatophyte - Plant that derives water from zones of saturation.

Potentiometric surface - Surface representing head in wells relative to the standard datum.

Seasonal high water table - Shallowest depth at which free water is first found during wet season; also shown by presence of gray mottles in soil structure.

Specific capacity - Rate of discharge of water from a well divided by drawdown of water level within the well during pumping.

Specific yield - Ratio of (1) the volume of water that aquifer material will yield by gravity to (2) the volume of aquifer material.

Surface-water distribution system - The network of canals (major conveyances which route flow to irrigation subdistricts); laterals (smaller conveyances which route flow to headgates); drains (conveyances which route excess water to wetlands); regulating reservoirs (holding areas which allow additional control on routing surface-water flow); and natural channels of the Carson River.

TCID - Acronym for Truckee-Carson Irrigation District. 
Tectonic - Pertaining to forces involved in or structures resulting from deformation of the Earth's crust. As applied to earthquakes, it is used to describe shocks that are not due to volcanic action or to collapse of caverns or landslides.

Transmissivity - Rate at which water is transmitted through a unit width of aquifer under a unit hydraulic gradient. Product of hydraulic conductivity of an aquifer multiplied by its saturated thickness.

Tuffaceous - Said of sediments that have as much as 50 percent volcanic fragments that were ejected during a volcanic explosion or eruption.

Unsaturated zone - Zone between land surface and water table where pore space in the aquifer material is not completely filled with water.

Water table - Surface in a ground-water body at which water pressure is atmospheric, or level at which water stands in a well that just penetrates a water body. In wells that penetrate to greater depths, the water level stands above or below the water table if an upward or downward component of ground-water flow exists.

Selected State of Nevada drinking-water standards for public water systems

[Units of measure, milligram per liter; --, standard does not exist for indicated constituent or property]

\begin{tabular}{|c|c|c|c|}
\hline Constituent or property & $\begin{array}{c}\text { Primary maximum } \\
\text { contaminant } \\
\text { level }^{1} \text { (MCL) }\end{array}$ & $\begin{array}{l}\text { Secondary } \\
\text { maximum } \\
\text { contaminant } \\
\text { level }^{2} \text { (SMCL) }\end{array}$ & $\begin{array}{c}\text { Criteria for } \\
\text { agricultural use or } \\
\text { beneficial use by } \\
\text { wildlife }\end{array}$ \\
\hline Arsenic & 0.05 & -- & 40 \\
\hline Boron & -- & -- & 1,000 \\
\hline Chloride & -- & 400 & - \\
\hline \multirow[t]{2}{*}{ Dissolved solids } & -- & 1,000 & 3,000 \\
\hline & & & - \\
\hline Fluoride & 4.0 & 2.0 & -- \\
\hline Iron & - & 6 & -- \\
\hline Manganese & -- & .1 & -- \\
\hline Mercury & .002 & -- & .05 \\
\hline Selenium & .01 & - & .035 \\
\hline Sulfate & -- & 500 & -- \\
\hline Uranium (proposed) & .02 & -. & -- \\
\hline
\end{tabular}

1 Primary maximum contaminant levels (MCL's) are health related and State and Federally mandated. Best available technology as determined by U.S. Environmental Protection Agency must be utilized to achieve these levels (Jeffrey A. Fontaine, Nevada Bureau of Consumer Health Protection Services, oral commun., 1989). MCL's are adopted by the State of Nevada (Nevada Bureau of Consumer Health Protection Services, 1980) from the National Drinking Water Regulations (U.S. Environmental Protection Agency, 1986a, 1986b).

${ }^{2}$ Secondary maximum contaminant levels (SMCL's) are based on aesthetic qualities and are enforceable by the State of Nevada. Best available technology is determined by the State of Nevada (Jeffrey A. Fontaine, oral commun., 1989). SMCL's are adopted from National Drinking Water Regulations (U.S. Environmental Protection Agency, 1986c, p. 587-590). SMCL's have not been established by the State of Nevada for copper, $\mathrm{pH}$, and zinc.

${ }^{3}$ Hoffman and others (1990, table 6). 



\title{
Hydrogeology and Potential Effects of Changes in Water Use, Carson Desert Agricultural Area, Churchill County, Nevada
}

\author{
By Douglas K. Maurer, Ann K. Johnson, and Alan H. Welch
}

\section{ABSTRACT}

Operating Criteria and Procedures established in 1988 for delivery of water for irrigation in the Newlands Project area include regulations and methods to increase Project efficiency. Public Law 101-618 of 1990 includes a target of 75-percent Project efficiency and a program of water-rights acquisition for wetlands maintenance. The directives could result in large reductions in water used for irrigation in the Carson Desert, potentially affecting ground-water supplies. Previous studies of the area have been evaluated to determine the current understanding of how aquifers are recharged, what controls the flow and quality of ground water, potential effects of changes in water use, and what additional information would be needed to quantify further changes in water use.

Inflow of surface water to the basin from Lahontan Reservoir averaged about 370,000 acre-ft/yr (acre-feet per year) from 1975 to 1992, supplying water for irrigation of more than 50,000 acres. More than half of the water released from the reservoir is lost to seepage, operational spills, and evaporation before delivery of about 170,000 acre-ft/yr to farm headgates. The volume of water delivered to farms that does not contribute to crop consumptive use (on-farm loss) is poorly known but could be as much as 60,000 acre-ft/yr. Consumptive use on irrigated land may be about 180,000 acre-ft/yr, of which 50,000 acre-ft/yr may be derived from the shallow aquifer. Outflow from irrigated land is a mixture of operational spill, runoff from irrigated fields, and ground-water seepage to drains. Total outflow averages about 170,000 to 190,000 acre- $\mathrm{ft} / \mathrm{yr}$. This water flows to wetlands at Carson Lake, Stillwater Wildlife Management Area, and Carson Sink.
Three sedimentary aquifers were previously defined in the basin: a shallow aquifer having highly variable lithology and water quality, an intermediate aquifer containing principally fresh water, and a deep aquifer having water of poor quality. The deep aquifer could possibly be divided into sedimentary and volcanic zones. In addition, a near-surface zone may exist near the top of the shallow aquifer where vertical flow is inhibited by underlying clay beds. A basalt aquifer near the center of the basin is the source of public supply and is recharged by the shallow, intermediate, and deep aquifers. Water levels in the basalt aquifer have declined about 10 feet from pre-pumping levels, and chloride and arsenic concentrations in the water have increased. The average depth to ground water has decreased beneath large areas of the Carson Desert since 1904 as a result of recharge of surface water used for irrigation. Ground water generally flows from west to east, and dissolvedsolids concentrations increase greatly near areas of ground-water discharge, where State of Nevada drinking-water standards commonly are exceeded.

Uncertainties in the rates of recharge to and discharge from the basin cause an imbalance in the calculated water budget. Estimates for total recharge range from 400,000 to 420,000 acre$\mathrm{ft} / \mathrm{yr}$, whereas estimates for discharge range from 630,000 to 680,000 acre-ft/yr. Estimates of inflow to and outflow from aquifers of the study area are as follows: shallow aquifer, more than 120,000 acre-ft/yr; intermediate aquifer, possibly more than 25,000 acre-ft/yr; deep aquifer, unknown; and basalt aquifer, about 4,000 acre-ft/yr. Estimates for flow volumes to and from the shallow and intermediate aquifers are based on assumed aquifer properties and could be in error by an order of magnitude or more. 
Conceptual models of the basin show that ground-water flow is downward from the shallow aquifer to the intermediate aquifer in the western part and near the center of the basin, and is upward in the eastern part of the basin. Little is known about flow in the deep aquifer. Nearsurface clay beds inhibit vertical flow near the center and eastern part of the basin except where breached by relict sand-filled channels of the Carson River.

Conceptual models of the basin show that changes in water use in the western part of the basin probably would affect recharge to the sedimentary and basalt aquifers. Near the center of the basin, water-use changes could affect the shallow and basalt aquifers but might have less effect on the intermediate aquifer. In the eastern part of the basin, changes could affect the shallow aquifer, but would probably not affect the intermediate or basalt aquifers.

If seepage is decreased by lining canals, and land is removed from production, water-level declines in the shallow aquifer could be greater than 10 feet as far as 2 miles from the lined canals. Depending upon the distribution of specific yield, decreasing recharge by 25,000 to 50,000 acre-ft/yr beneath 30,000 acres could cause water levels to decline from 4 to 17 feet. Where ground water supplements crop consumptive use, water levels could temporarily rise when land is removed from production. Where water is pumped from a near-surface zone of the shallow aquifer, water-level declines might not greatly affect pumped wells where the nearsurface zone is thickest, but could cause wells to go dry where the zone is thin.

The understanding of surface-water and ground-water relations, recharge and discharge of ground water, ground-water movement, and the potential effects of changes in water use in the Carson Desert can be refined by studying (1) the extent of potable water in the intermediate and basalt aquifers, (2) lithology and specific yield of aquifer materials, (3) data on ground-water levels and quality, and (4) data on surface-water flow and quality, as well as monitoring the effects of changes in water use as they take place.

\section{INTRODUCTION}

Public law, Federal agency directives, and courtdecreed operating criteria could result in a significant reduction in agricultural water use in the Newlands Project near Fallon, Nev. The Operating Criteria and Procedures (OCAP) currently in place for the Newlands Project establish a potential target of 68.4-percent efficiency in the delivery system (U.S. Department of the Interior, 1988, p. 4). In addition, Public Law 101-618, signed on November 16, 1990, directs the Bureau of Reclamation (BOR) to study methods of increasing Project delivery efficiency to 75 percent within 12 years of the date of enactment of the legislation. This public law also directs the U.S. Fish and Wildlife Service (USFWS) to acquire water rights from willing sellers sufficient to maintain 25,000 acres of wetlands in Lahontan Valley. With increased Project efficiency, the volume of water available to wetland areas is estimated to decrease by 25-55 percent because Project outflow is the sole source of water for wetland supply (Bureau of Reclamation, 1987a, p. 2-29). To accomplish these goals, large areas of irrigated land would need to be taken out of production. The water-rights acquisition program could reduce water delivered for irrigation by as much as 125,000 acre- $\mathrm{ft} / \mathrm{yr}$ (U.S. Fish and Wildlife Service, 1992, p. 6).

The effect of water-use changes on local groundwater supplies is not known and is a major public concern. The complex ground-water system in the area has been divided into four separate aquifers: shallow, intermediate, and deep alluvial aquifers and a basalt aquifer (Glancy, 1986). The shallow and intermediate aquifers are tapped by more than 5,000 wells supplying rural domestic users, and the basalt aquifer is the main source of supply for the city of Fallon and the U.S. Naval Air Station near Fallon. Changes in the yield of these aquifers or in their water quality could affect a large part of the local population. In February 1992, the U.S. Geological Survey (USGS), in cooperation with the BOR, began a synthesis of previous hydrologic studies in the basin to summarize what is known about the hydrologic system. 
This report provides a summary of the hydrology of the Carson Desert that will assist water managers in making informed decisions about resource management in the Carson Division of the Newlands Project (inset, pl. 1). The study described herein was limited to the Carson Division of the Newlands Project and surrounding areas in the Carson Desert hydrographic area that are irrigated with releases from Lahontan Reservoir.

A literature search was made to determine the extent of existing data and to compile results of reports discussing hydrogeology, ground-water and surface-water flow, and ground-water and surfacewater quality in and near the Carson Desert. The compiled literature describes work from the early 1900 's to reports in progress at the USGS and the BOR.

Concepts described in these reports on hydrogeology, movement of surface water and ground water, recharge to aquifers, and geochemistry of surface water and ground water are summarized and used to develop a conceptual model of the entire system. Data compiled for this study were analyzed to (1) determine natural processes important in controlling the flow of surface water and ground water in the Carson Desert, (2) develop a conceptual model of hydrologic relations in the Carson Desert, and (3) determine if detailed analysis of existing data or additional study would provide further understanding of the processes controlling the movement of water in the Carson Desert. Detailed analysis of all existing data is beyond the scope of this study.

The conceptual model developed is used to describe potential effects of water-use changes on aquifer yield and ground-water quality. Limitations of the model are discussed, and these limitations are considered in formulating data-collection networks and detailed studies that would help to further quantify the effects of changes in water use.

Details regarding the location of existing canals and drains and the direction of flow in the surfacewater distribution system are not currently available (June 1993). Therefore, this report does not provide precise locations for sites in proposed data-collection networks.

\section{Geographic Setting}

The Carson Desert hydrographic area covers about $2,000 \mathrm{mi}^{2}$ in Churchill County near Fallon, Nev., about $60 \mathrm{mi}$ east of the State capitol, Carson
City (inset, pl. 1; Glancy and Katzer, 1975, p. 2). The basin is the natural terminus of the Carson River. As used in this report, the term "Carson Desert" applies to the entire hydrographic area shown on plate 1 and excludes Packard Valley. The floor of the Carson Desert lies at an altitude of about 3,900 ft and is bounded on the east by the Stillwater Range, which reaches an altitude of about $8,800 \mathrm{ft}$, and the Lahontan Mountains at an altitude of about $4,400 \mathrm{ft}$ (pl. 1). The basin is bounded on the south by several discontinuous mountain blocks: the Desert, White Throne, Blow Sand, Cocoon, and Bunejug Mountains, which range in altitude from about 4,800 to $6,400 \mathrm{ft}$. The Salt Wells Basin extends about $15 \mathrm{mi}$ to the southeast from the Carson Desert, between the Bunejug and Lahontan Mountains. The basin is bounded on the west by the Hot Springs and Dead Camel Mountains, both about 5,300 ft in altitude, and on the north by the West Humboldt Range, which is about $5,500 \mathrm{ft}$ in altitude.

The Carson River and the Truckee Canal enter the basin from the west between the Hot Springs and Dead Camel Mountains, where the combined flow is stored in Lahontan Reservoir. During extremely wet years in the Humboldt River Basin, the Humboldt River flows into the Carson Desert from the north through a gap between the West Humboldt Range and the Hot Springs Mountains.

The area in and near irrigated land of the Carson Division in the southern end of the Carson Desert is called Lahontan Valley, although it is not topographically separated from the Carson Desert.

The Newlands Project, constructed from 1903 to 1915, was one of the first reclamation projects in the United States. Diversion and impoundment of surface water for the Newlands Project begin in the headwaters of the Truckee and Carson Rivers. Flow is routed through the natural channels of the rivers and by way of the Truckee Canal to Lahontan Reservoir. Since about 1915, some flow from the Truckee River has been diverted to Lahontan Reservoir through the Truckee Canal. Since the mid-1960's, the diversion has totaled about 40 percent of the Truckee River flow (Hess and others, 1993, p. 355, 363). The Truckee Division of the Newlands Project (inset, pl. 1) comprises about 3,000 acres irrigated near Fernley and about 900 acres irrigated in the Carson Desert using water from the Truckee Canal. The average area irrigated in the Carson Division of the Newlands Project from 1984 to 1990 was about 56,000 acres (fig. 1) (Charles Johnson, Bureau of Reclamation, written commun., 1993). 


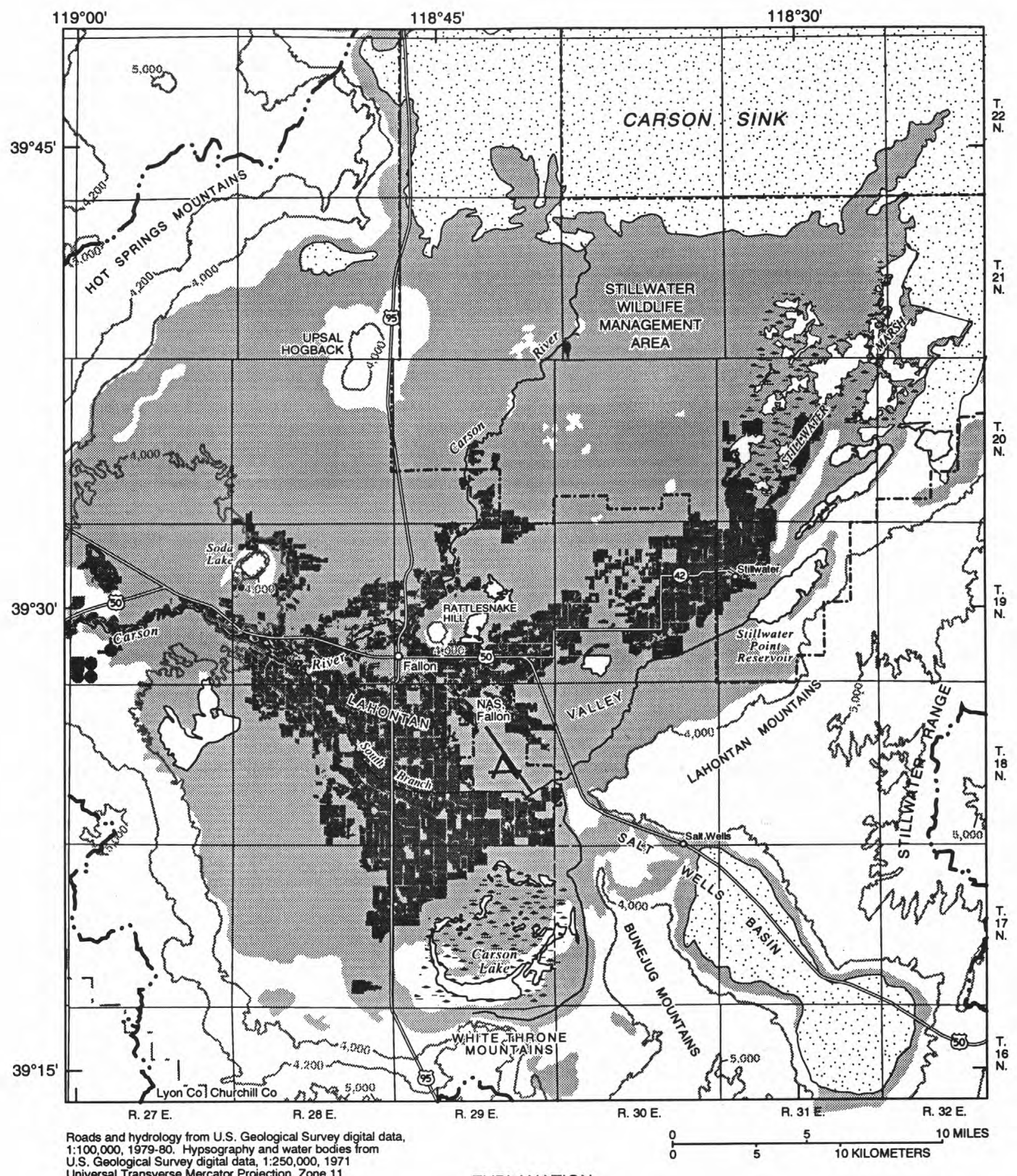

EXPLANATION

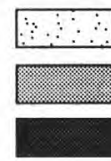

Discharging playa - From Glancy and Katzer $(1975, \mathrm{pl} .1)$

Phreatophytes - From Glancy and Katzer $(1975$, pl. 1)

Irrigated land, 1984-90 - From Bureau of Reclamation digital data (Charles Johnson, Bureau of Reclamation, 1993)

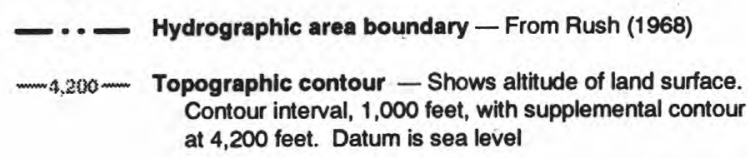
at 4,200 feet. Datum is sea level

Figure 1. Discharging playas, phreatophytes, and irrigated land in Carson Desert hydrographic area. 
Alfalfa is the predominant crop grown on land irrigated by the Newlands Project and accounts for about 53 percent of the Project area. Pasture and other forage crops account for 23 percent, and cereal and vegetable crops account for the remainder (Bureau of Reclamation, 1992b, p. 37).

The Carson Desert lies in the rainshadow of the Sierra Nevada (inset, pl. 1). The floor of the basin annually receives about 5 in. of precipitation and the Stillwater Range receives from 8 to 12 in. (Nevada Division of Water Resources, 1971). Potential evaporation rates are more than 10 times this amount, averaging about $60 \mathrm{in} / \mathrm{yr}$ (Bureau of Reclamation, 1987a, p. 2-24). Temperatures range from an average minimum of about $17^{\circ} \mathrm{F}$ to an average maximum of about $90^{\circ} \mathrm{F}$ (period of record, 1941-70; Dollarhide, 1975 , p. 3). The normal frost-free growing season starts about mid-May and ends about mid-September (Guitjens and Mahannah, 1976, p. 3).

Agriculture is a major source of income in the Fallon area. Most water used for agriculture is released from Lahontan Reservoir; very few wells supply ground water for irrigation. The basalt aquifer beneath Fallon (fig. 12) is the sole source of water for municipal use and for use at the Naval Air Station, which is the largest employer in Fallon. More than 5,000 domestic wells, which tap the shallow and intermediate aquifers, supply the rural population of the area.

Associated with the irrigated lands are wetlands of Carson Lake, the Stillwater Wildlife Management Area (WMA) and National Wildlife Refuge, and the Fallon National Wildlife Refuge (pl. 1). Sand dunes, playas, and areas vegetated with phreatophytes such as greasewood, rabbitbrush, saltgrass, and marsh grasses cover the remainder of the Carson Desert lowlands (fig. 1). The Carson Sink covers the northern part of the Carson Desert. During years of extremely high flows, outflow from the Stillwater wetlands reaches the Carson Sink along with flow from the Humboldt River. The extremely wet years 1983 and 1984 caused the Carson Sink to become, temporarily, the largest water body in the State of Nevada, covering about 212,000 acres (Rowe and Hoffman, 1990, p. 37).

The Stillwater wetlands are jointly managed by the USFWS and the Nevada Department of Wildlife (NDOW). The Stillwater wetlands are divided into the Stillwater WMA, covering about 200,000 acres, and the Stillwater National Wildlife Refuge, covering about 77,500 acres. Carson Lake wetlands are managed by the NDOW and cover about 34,000 acres, with about 13,000 acres supporting community pasture lands leased to local ranchers for grazing (Hallock and Hallock, 1993; Bureau of Reclamation, 1992b, p. 37).

Prior to the Newlands Project, the Stillwater and Carson Lake wetlands totaled a maximum of about 60,000 acres and wetlands of the Fallon National Wildlife Refuge covered about 26,000 acres (Hoffman and others, 1990, p. 5). Diversion and consumptive use of surface water by crops has completely dried up wetlands of the Fallon National Wildlife Refuge in most years and reduced the wetland areas at Stillwater WMA and Carson Lake. Some wetland areas were produced within the Newlands Project area, including regulatory reservoirs and numerous small wetlands scattered throughout the Project area.

From 1986 to 1991, wetland areas near irrigated land in the Carson Desert ranged from more than 45,000 acres in wet years to less than 7,000 acres in dry years (Norman A. Saake, U.S. Fish and Wildlife Service, written commun., 1993).

Before operation of the Newlands Project, about 14,000 acres of land were irrigated using natural flows of the Carson River (Lee and Clark, 1916, p. 670). Since 1926 , the Project has been operated and maintained by the Truckee-Carson Irrigation District (TCID). Numerous lawsuits over the diversion of Truckee River water have centered on the use of Truckee River flows to maintain Lahontan cutthroat trout and endangered Cui-ui lake sucker fisheries in Pyramid Lake (inset, pl. 1). Between 1909 and 1968, the level of Pyramid Lake dropped $80 \mathrm{ft}$ in response to diversions from the Truckee River (Harris, 1970). Subsequently, the level of Pyramid Lake was $25 \mathrm{ft}$ higher in 1986, then declined $15 \mathrm{ft}$ by 1992 (Hess and others, 1993, p. 4). Court decisions and task forces convened by the U.S. Department of the Interior led to implementation of OCAP for the Newlands Project to reduce the need for Truckee River diversions. The OCAP were initiated in 1967, and the most recent version took effect in April 1988 (Bureau of Reclamation, 1992b, p. 40).

Project efficiency, as defined by OCAP, is the total annual headgate delivery, divided by the total annual diversions for the Project (Bureau of Reclamation, 1987a, p. 1-6). Thus, the efficiency is defined only for the conveyance of water to the farm headgate and does not address on-farm efficiency. Project efficiency ranged from 53 to 63 percent from 1981 to 1990 (Bureau of Reclamation, 1992b, p. 15). Since 
implementation of OCAP in 1988, the area has been under extreme drought conditions. Because OCAP regulations are mandated only for years with more than 70-percent delivery, operation of the Project as envisioned by OCAP has not been achieved.

\section{Acknowledgments}

The authors thank Willis Hyde of the TruckeeCarson Irrigation District, Norman A. Saake of the Nevada Division of Wildlife, Gary Shellhorn of the U.S. Fish and Wildlife Service, Gordon Lyford, Dave Overvold, Carol Grenier, and Roger LaSueur of the Bureau of Reclamation, Dr. John Guitjens of the University of Nevada, Reno, and Randy Pahl of the Nevada Division of Water Planning-all of whom provided valuable information and insight from their experience with the Newlands Project.

\section{HYDROGEOLOGIC FRAMEWORK}

Ground-water movement in the Carson Desert is in part controlled by the lithology and geometry of the geologic units through which ground water flows. The lithology of a geologic unit depends partly on the environment in which it was deposited. The geometry of a unit depends on depositional environment, along with the local and regional geologic and structural history. The following sections summarize available information on the geologic history, lithology and geometry of geologic units, and structural setting of the Carson Desert.

\section{Geologic History}

Rocks and sediments in the Carson Desert hydrographic area record two geologic eras: the Mesozoic, which spanned about 240 to $66 \mathrm{Ma}$ (million years ago), and the Cenozoic, which spans $66 \mathrm{Ma}$ to the present. The Mesozoic Era is divided into three periods (from oldest to youngest): Triassic, Jurassic, and Cretaceous. The Cenozoic Era is divided into two periods (from older to younger): Tertiary and Quaternary. The oldest rocks preserved in the Carson Desert (pl. 1) are Late Triassic (about $225 \mathrm{Ma}$ ) in age (Johnson, 1977, pl. 1). From this time until Middle Jurassic time (about $170 \mathrm{Ma}$ ), the study area was covered by a sea that deposited marine sediments (Stewart, 1980, fig. 32 and p. 65-67). The study area (and much of west-central Nevada) was uplifted and subjected to gentle folding, faulting, and erosion above sea level during Middle Jurassic time (Stewart, 1980, fig. 36, and p. 71, 76). Mafic volcanic and plutonic rocks were emplaced at this time (Speed, 1966). During the Cretaceous (138 to 66 $\mathrm{Ma})$, the Carson Desert was probably above sea level and eroding, as evidenced by the paucity of sedimentary and volcanic rocks preserved from that time period (Stewart, 1980, p. 73). Plutonism occurred throughout the study area during Cretaceous time (Willden and Speed, 1974, p. 1).

Very few rocks of early Tertiary age (66 to $34 \mathrm{Ma}$ ) are preserved in the study area (Stewart, 1980, p. 98-100). The Carson Desert probably had substantial relief at this time and was eroding faster than the rate of mountain building (Stewart, 1980, p. 5). During the middle Tertiary, from 34 to $17 \mathrm{Ma}$, voluminous felsic volcanic eruptions occurred across the eastern part (pl. 1) of the study area (Burke and McKee, 1979, p. 183). At about $17 \mathrm{Ma}$, the Great Basin began a period of extensional faulting that has continued to the present, creating the north-trending basin-and-range topography of today (Stewart, 1980, p. 110). The total amount of extension across the Great Basin is estimated to be between 10 and 50 percent, with local extension exceeding 100 percent (Stewart, 1978, p. 1). From 17 to $12 \mathrm{Ma}$, volcanic rocks (pl. 1) were extruded, and extensional block faulting formed shallow basins, which contained ephemeral lakes that collected sediments (Axelrod, 1956, p. 97; Hastings, 1979, p. 520). From about 12 $\mathrm{Ma}$ to about $5 \mathrm{Ma}$, mafic and minor felsic eruptions accompanied the block faulting; since about $5 \mathrm{Ma}$, however, only infrequent mafic volcanism has accompanied the faulting (Hastings, 1979, p. 520; Stewart, 1980 , p. 5). Beginning at about $17 \mathrm{Ma}$, the downfaulted basins trapped sedimentary deposits and volcanic rocks more than $6,000 \mathrm{ft}$ thick (Garside and Schilling, 1979, p. 14; Stewart, 1980, p. 5 and 110).

Biogeographic evidence indicates that in late Tertiary time, from 17 to $1.6 \mathrm{Ma}$, the valleys of the Great Basin were near $2,000 \mathrm{ft}$ above sea level and the Sierra Nevada stood near 4,000 ft above sea level (Axelrod, 1956, p. 2; 1962, p. 183). At that time the Carson Desert was larger than it is today and probably still drained to the ocean (Axelrod, 1956, fig. 16; Morrison, 1964, p. 96-97). The central Sierra Nevada was uplifted 4,000 to $7,000 \mathrm{ft}$ and tilted westward during late Tertiary and early Quaternary time (Axelrod, 1962; Huber, 1981; Winograd and others, 1985). This uplift cut off Nevada's drainage to the ocean and increased the rainshadow effect on the Great Basin, changing the climate from subhumid to semiarid (Morrison, 1964, p. 97). While the Sierra Nevada was being uplifted, the entire Great Basin was 
uplifted 1,000 to $3,000 \mathrm{ft}$ (Gable and Hatton, 1983) and the Carson Desert area was tilted slightly northward (Mifflin and Wheat, 1971; 1979).

Quaternary time is divided into two epochs: the Pleistocene, 1.6 Ma to $10 \mathrm{ka}$ (thousands of years ago), and the Holocene, $10 \mathrm{ka}$ to the present. In the Carson Desert during Pleistocene time, lakes formed, expanded, and shrank (Axelrod, 1956; Morrison, 1964). Several times, under the influence of Pleistocene glacial climates, these lakes coalesced to form ancient Lake Lahontan, which covered much of the northwestern Great Basin (Morrison, 1964) and had a history similar to that of Lake Bonneville in Utah (Morrison and Frye, 1965; Thompson and others, 1986; Morrison, 1991). Ancient Lake Lahontan was probably one large, deep lake for most of the time from about $1.2 \mathrm{Ma}$ to $850 \mathrm{ka}, 650$ to $600 \mathrm{ka}, 400$ to $130 \mathrm{ka}$, and again from 25 to $10 \mathrm{ka}$ (Benson, 1991, p. 115; Benson and others, 1990, p. 241; Morrison, 1991, fig. 6). At its highest stand, ancient Lake Lahontan had a maximum area of $8,300 \mathrm{mi}^{2}$ and was more than $500 \mathrm{ft}$ deep in the Carson Desert (Davis, 1978 , p. 2; Morrison, 1991, p. 288). When water levels fell below the 4,290-ft altitude, Lake Lahontan began shrinking into separate lakes (Benson, 1978, fig. 2; Davis, 1982, figs. 4-6).

The rivers flowing into ancient Lake Lahontan changed course at various times during the Pleistocene. During middle and late Pleistocene time ( 800 to $10 \mathrm{ka}$ ), the Walker River usually flowed into the Carson River and the Carson Desert, rather than into Walker Lake as it does today (Benson and Thompson, 1987, p. 84; Morrison, 1991, p. 288). Sometime from 11 to $7 \mathrm{ka}$, the Walker River changed its course and flowed into Walker Lake (Davis, 1982, p. 63, 66-67). This rerouting of the Walker River contributed to desiccation of Lake Lahontan and extensive formation of dunes from about 7 to $5 \mathrm{ka}$ (Davis, 1982, p. 66). Frequently during Pleistocene time, the Humboldt River flowed into the Black Rock Desert instead of into the Humboldt Sink-Carson Sink area (Davis, 1982, 1990). At least once during late Pleistocene time (200 to $10 \mathrm{ka}$ ), the Truckee River flowed into the Carson Desert instead of into the Pyramid Lake Basin (Jones, 1933, p. 105-6, pl. 16; Morrison and Davis, 1984a, p. 253).

According to Morrison (1964, p. 28-71), thick clay beds were deposited in the deeper parts of ancient Lake Lahontan. Rivers flowing into the lake deposited sand, gravel, silt, and minor amounts of clay on deltas in delta-front, channel, swamp, and flood-overbank areas. In the Carson Desert, deltas were formed primarily in the west where the Carspn River flowed into Lake Lahontan. Sand and gravel beaches and bars were formed by wave action along the shorelines of Lake Lahontan and, during dry periods when the lake level was low, large sand-dune and sand-sheet complexes formed extensively along the lakeshore. Alluvial-fan deposits are preserved in highland valleys where streams left the mountains and spread out onto the Carson Desert floor. Basaltic volcanism occurred sporadically in several isolated areas (pl. 1) of the Carson Desert during Quaternary time.

Ancient Lake Lahontan began drying up after its last high stand about $14 \mathrm{ka}$ (Benson, 1991, p. 115). Since the last high stand of Lake Lahontan, the Carson Desert area is believed to have rebounded isostatically by 40 to $55 \mathrm{ft}$ (Mifflin and Wheat, 1971). By about $7 \mathrm{ka}$, Lake Lahontan had almost completely dried up (Morrison, 1991, p. 300). After that time several temporary, shallow lakes (maximum depth, 20-85 ft) grew and receded in the Carson Desert (Morrison, 1964, p. 75-87). Wet periods have alternated with dry periods throughout the last 4,000 years, with the last 100 years being dry (Davis, 1982, p. 66-68).

\section{Structural Setting}

Three major regional fault systems intersect in the Carson Desert: the Walker Lane, the Midas Trough, and the basin and range. Walker Lane faults trend northwest, Midas Trough faults trend northeast, and basin-and-range faults trend north-northeast.

The Walker Lane is a system of northwesttrending right-lateral strike-slip faults that is 80 to 120 mi wide and extends about $400 \mathrm{mi}$ along the NevadaCalifornia border from near Las Vegas to northwest of Reno (Locke and others, 1940; Rowan and Wetlaufer, 1973; Stewart, 1980, p. 86; Morrison, 1991 , p. 285). This fault system has been active since $15 \mathrm{Ma}$ or earlier (Stewart, 1980, p. 86). Largescale displacement of as much as $120 \mathrm{mi}$ along the Walker Lane fault system has been suggested by some geologists (Stewart, 1980, p. 86). The Carson Desert lies near the eastern margin of the Walker Lane. In the Carson Desert (pl. 1), faults that parallel the Walker Lane are common in the Salt Wells Basin and in the area west of the Bunejug and Cocoon Mountains (Bruce, 1981, fig. D4).

The Midas Trough system is oriented northeast, perpendicular to the Walker Lane, and extends from near Carson City, Nev., through Idaho and Yellowstone National Park into Montana (Rowan and Wetlaufer. 1973). In the Carson Desert area, the Nidas of qugh system crosses the Hot Springs Mountains and bounds the West Humboldt Range

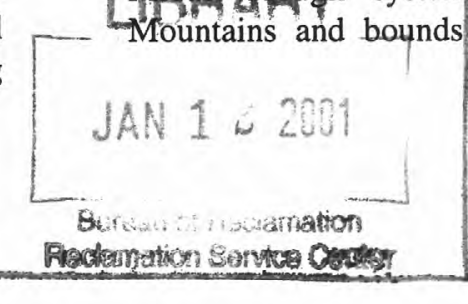


(Bruce, 1981, fig. D4). Rowan and Wetlaufer (1973) infer that the Midas Trough system has been active since about $15 \mathrm{Ma}$ as a wide zone of left-lateral faulting.

The basin-and-range structures generally trend north-northeast but range from north-northwest to northeast. These structures are superimposed on both the Walker Lane and Midas Trough structures (Bruce, 1981, p. 167) and formed during the past 15 million years (Axelrod, 1957; Stewart, 1980, p. 114-115). A complex system of horsts (upthrown blocks, such as the Sierra Nevada) and grabens (downthrown blocks, such as Lake Tahoe) was created in the Carson Desert by the intersection of the three structural trends (fig. 2). Intersections of the various fault systems probably form extensive zones of crushed rock within the Cenozoic volcanic rocks and the Mesozoic rocks giving them fracture permeability conducive to transmission and storage of geothermal water (Morgan, 1982, p. 28). Faults throughout the Carson Desert are commonly marked by springs, seeps, and scarps (Morrison, 1964, p. 92).

The basin-and-range fault system is still active. In 1954, three earthquakes of magnitude 6.6 to 6.8 that had epicenters $2.8 \mathrm{mi}$ east-northeast of Salt Wells occurred between the south ends of the Stillwater Range and the Lahontan Mountains (Morrison, 1964, p. 95-96; Ryall, 1977). The fault zone along which these earthquakes occurred, informally named the Rainbow Mountain Fault, can be traced (pl. 1) in an en echelon pattern parallel to the western scarp of the Stillwater Range from near Salt Wells for more than 19 mi north into the Stillwater Marsh area (Morrison, 1964, p. 95; Morgan, 1982, p. 28).

The overall effect of basin-and-range faulting in the Carson Desert area has been to lift the surrounding mountains and to drop the Carson Desert. The Carson Desert is still being downdropped. A secondorder leveling survey of the Hot Springs Mountains in June 1983 and repeated in May 1984 found subsidence of 0.24 to 0.6 in. in that year $(\mathrm{CH} 2 \mathrm{M}$ Hill, 1984, p. IV-4; Chevron Resources Company, 1987a, p. 2-2). During the 1954 earthquakes, benchmarks were dropped as much as $7 \mathrm{ft}$ (Bureau of Land Management, 1975, p. 19).

Several horsts and grabens have been identified in the subsurface (fig. 2) by seismic surveys, gravity surveys, and drilling (Phillips Petroleum Company, 1973; Erwin and Berg, 1977; Chevron Geophysical Company, 1977; Chevron Resources Company, 1979a; 1979b; 1987; Hastings, 1979; Reynolds and associates, 1975). Because of these buried horsts and grabens, the thickness of the Tertiary and Quaternary sections beneath the floor of the Carson Desert ranges from 2,000 to $12,000 \mathrm{ft}$ (Morrison, 1964; Chevron
Resources Company, 1979a; 1979b; 1987; Garside and Schilling, 1979; Hastings, 1979; Union 76 Geothermal Division, [1979?]). The largest graben delineated in the Carson Desert (fig. 2) extends from east of Lone Rock south-southwestward into the central Stillwater Marsh area where Mesozoic rocks are greater than $12,000 \mathrm{ft}$ below land surface (Hastings, 1979). Two other possible grabens have been identified under Carson Lake and under the southeastern part of the Soda Lakes area (Morrison, 1964, p. 94; Chevron Geophysical Company, 1977). Horsts have been delineated (fig. 2 and pl. 1) just west of Lone Rock, east of the Timber Lake well, and possibly under Upsal Hogback (Hastings, 1979, fig. 2; Chevron Geophysical Company, 1977).

\section{Description and Distribution of Hydrogeologic Units}

Available geologic information for the Carson Desert is summarized on plates 1-3. Plate 1 is a generalized geologic map of the Carson Desert hydrographic area. Similar rock types are grouped together from the geology described by John H. Stewart (U.S. Geological Survey, written commun., 1987) and Morrison (1964). To further simplify plate 1 , only Quaternary faults in basin-fill deposits are shown (Bell, 1984; Greene and others, 1991). Shown on plate 1 , for 22 drillholes, are depths to the tops of the Tertiary section (generally sedimentary rock), the Tertiary volcanic section, and the Mesozoic section.

Plate 2 shows geologic sections across the Carson Desert. The geologic sections are based on rock descriptions in drillers' and geologists' logs of 12 of the 22 wells on plate 1 that were drilled to depths greater than $800 \mathrm{ft}$. Holes that were not drilled vertically are projected to vertical for these geologic sections. Most of the contacts used for these geologic sections are poorly defined. The contact between the early and late Lake Lahontan sediments is speculative. The contact between the youngest Tertiary sediments (or sedimentary rocks) and the oldest Quaternary sediments is gradational and difficult to discern. The Quaternary sediments contain only minor amounts of volcanic material, whereas the Tertiary sediments (or sedimentary rocks) contain major amounts of yolcanic material. For these geologic sections, the top of the Tertiary section was defined by a change from dominantly nontuffaceous to dominantly tuffaceous material in the drill cuttings, or by a change from dominantly unconsolidated to dominantly consolidated materials. Dates based on the ages of fossils were used to define the top of the Tertiary in two 


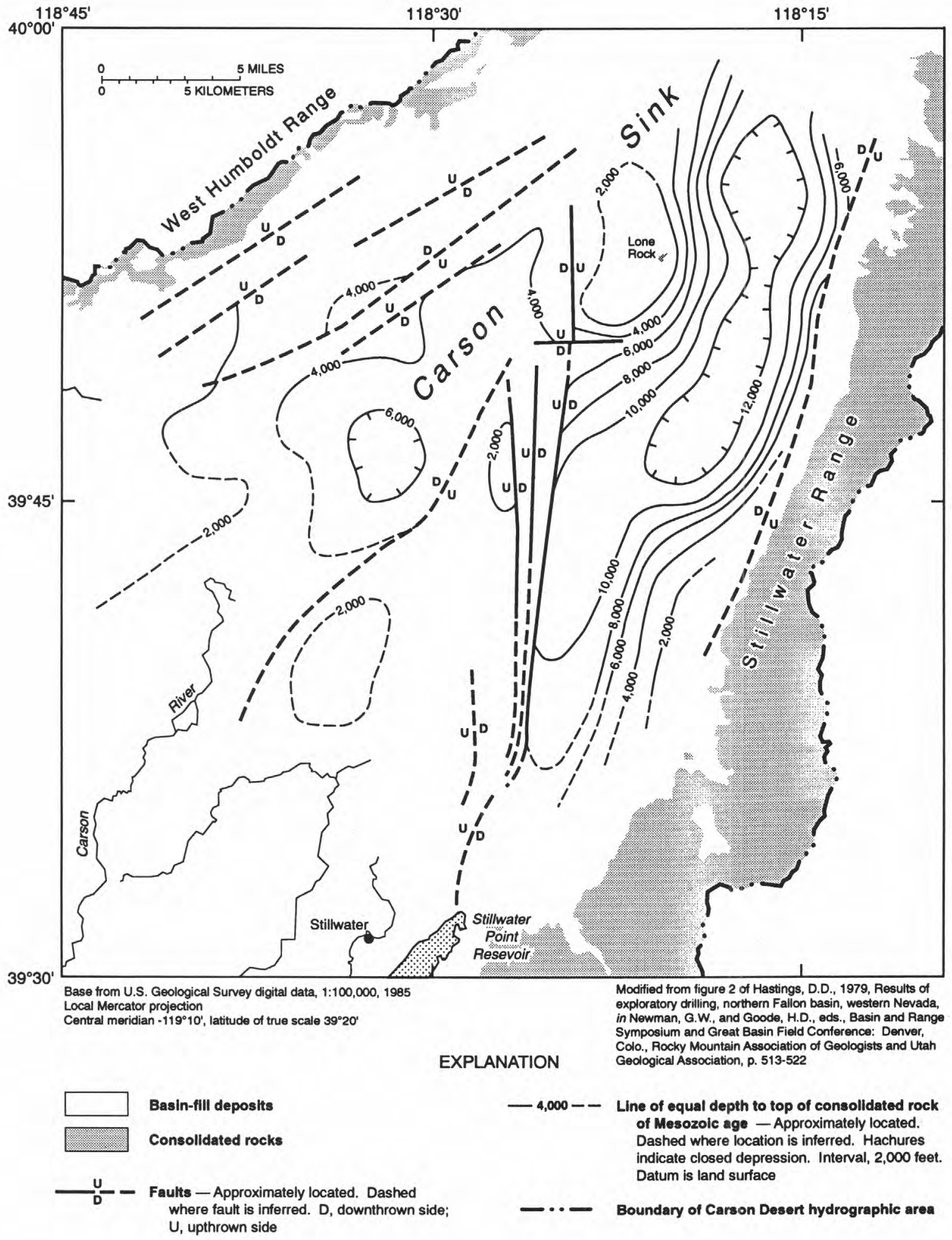

Figure 2. Faults and depth to top of consolidated rocks of Mesozoic age, northern Carson Desert, as inferred from seismic and gravity surveys. 
drillholes-the Halbout Federal No. 1 and the Standard-Amoco S.P. Land No. 1. The Tertiary sedimentary and mafic volcanic rocks are irregularly interbedded; the number, thickness, and lateral extent of the interbeds vary greatly beneath the Carson Desert. The contact between sedimentary and mafic volcanic units is found at varying depths in the Tertiary section and is generally repeated. Because these Tertiary rock sequences differ widely from place to place, correlation of individual units over large areas is not possible.

Plate 3 shows the relative age and permeability of Quaternary sediments deposited from $130 \mathrm{ka}$ to present and shows exposed channels formed by the Carson River that are younger than $11 \mathrm{ka}$. The map was generated from data presented by Morrison (1964, pl. 3-6, 11) and Dollarhide (1975). Areas greater than 0.5 to $1 \mathrm{mi}^{2}$ were grouped by age and relative permeability, which was estimated by assuming that sand is permeable and that silt and clay are relatively impermeable.

\section{Consolidated Rocks}

In the Carson Desert, consolidated rocks consist of Mesozoic (about 240 to $66 \mathrm{Ma}$ ) and Cenozoic (66 $\mathrm{Ma}$ to present) sedimentary and igneous rocks. Mesozoic rocks are exposed widely along the northeast, northwest, and southeast margins of the Carson Desert; elsewhere they are exposed only in small windows eroded through the overlying Cenozoic deposits (Willden and Speed, 1974, p. 5). The entire Carson Desert is thought to be underlain at depth by Mesozoic rocks (Hastings, 1979, p. 517). Mesozoic rocks exposed in the Carson Desert include sedimentary rocks, felsic intrusive igneous rocks, and mafic intrusive and extrusive igneous rocks (Page, 1965; Willden and Speed, 1974, pl. 1, p. 7-10, 13-18; Benoit and others, 1982, p. 7; John H. Stewart, 1987, written commun.; Greene and others, 1991).

Consolidated Cenozoic rocks are common in the Carson Desert; they include Tertiary (66 to $1.6 \mathrm{Ma}$ ) felsic and mafic volcanic rocks, Tertiary sedimentary rocks, and Quaternary (1.6 Ma to present) mafic volcanic rocks. Semiconsolidated and unconsolidated Cenozoic material is abundant in the Carson Desert and consists of Tertiary and Quaternary sediments. Wide variations in the thickness and areal extent of Tertiary units were caused by tectonic activity during and after deposition of the Tertiary rocks. During Tertiary time, different areas of the basin were alternately uplifted or downdropped; uplifted areas were eroded and provided sediment to the downdropped areas, where sedimentary and volcanic material accumulated (Axelrod, 1956).

In the Carson Desert, a mafic volcanic unit and a complexly interbedded tuffaceous sedimentary unit generally underlie Quaternary deposits. The mafic volcanic unit, which is Tertiary in age, consists of the volcanic parts of the Chloropagus and the Desert Peak Formations of Axelrod (1956) and of the Truckee Formation (King, 1878) and the entire Bunejug Formation (Morrison, 1964, p. 11-14). These volcanic rocks, which have an aggregate thickness of more than $4,900 \mathrm{ft}$, consist of basalt and andesite flows and tuffs (Axelrod, 1956, p. 95-101; Page, 1965). The sedimentary sequence, which is Tertiary in age, includes parts of the Chloropagus and Desert Peak Formations of Axelrod (1956) and part of the Truckee Formation (King, 1878). This sedimentary sequence, which is tuffaceous, has an aggregate thickness of more than $2,300 \mathrm{ft}$ and consists of shale, siltstone, sandstone, conglomerate, limestone, and diatomite (Axelrod, 1956, p. 95-101). The Truckee and Bunejug Formations are locally interbedded, but basalt of the Bunejug Formation generally overlies tuffaceous sediments and tuffs of the Truckee Formation (Morrison, 1964, p. 14). The Bunejug Formation caps many of the low mountains rimming the southern Carson Desert (Morrison, 1964, p. 14-15) but is missing in many drillers' logs of wells in the Carson Desert (pl. 2).

Consolidated rocks of Quaternary age (1.6 Ma to present) are uncommon in the study area. Mafic volcanic activity occurred in four areas of the Carson Desert during the Pleistocene: Rattlesnake Hill, Upsal Hogback, Lone Rock, and Soda Lakes. Deposits in the first three are consolidated, but the Soda Lakes volcanic-sand complex is semiconsolidated.

Rattlesnake Hill is a volcanic cone composed of basalt that was dated by whole-rock potassium-argon analysis to be $1.03 \pm 0.05 \mathrm{Ma}$ (Evans, 1980, p. 20). The cone has been eroded and is partially buried by ancient Lake Lahontan sediments (Morrison, 1964, p. 23). The basaltic eruptions from this cone were quiet except for a final explosive phase, which plugged the throat of the cone with agglomerate (Morrison, 1964, p. 23).

Upsal Hogback, $10 \mathrm{mi}$ north of Fallon, is a volcanic complex dated at 35 to $11 \mathrm{ka}$; the complex consists of seven overlapping, well-indurated basaltic cinder-tuff cones that are rimmed with unconsolidated basaltic sand (Morrison, 1964, p. 38; Davis, 1978, p. 24). Upsal Hogback basaltic tuffs are interbedded with ancient Lake Lahontan sediments (Davis, 1978, p. 41). 
Lone Rock, which is in the northeastern part of the Carson Desert, is a basalt cinder cone that is thought to be about the same age as the basalt of Rattlesnake Hill (Hastings, 1979, p. 519).

\section{Semiconsolidated and Unconsolidated Sediments}

In the Carson Desert, sediments of Quaternary and some of Tertiary age are either semiconsolidated or unconsolidated. The consolidated and semiconsolidated Tertiary sediments are discussed in the previous section. Quaternary deposits are the most widely exposed geologic units (pls. 1 and 3) in the Carson Desert. They mainly consist of lacustrine (clay and silt), alluvial-fan (sand and gravel), and eolian (sand) deposits (Morrison, 1964; Willden and Speed, 1974). Morrison (1964; 1991) mapped Quaternary sediments in the southern Carson Desert in detail and described the stratigraphy of lake and interlake sequences. Benson (1978), Lao and Benson (1988), Benson and others (1990), and Thompson and others (1986) refined the stratigraphy and resolved some conflicts among absolute-age determinations for the ancient Lake Lahontan sediments. Davis (1978; 1982), Sarna-Wojcicki and Davis (1991), and SarnaWojcicki and others (1991) mapped and radiometrically dated volcanic ash beds in the Quaternary sediments. Their work further refined the relative ages of the sediments and provided useful marker beds.

The thickness of Quaternary sediments in the southern and northeastern Carson Desert ranges from zero to thousands of feet (pl. 1). The contact between Quaternary and Tertiary sediments (pl. 1) is difficult to identify in drillholes unless the Bunejug Formation overlies Tertiary sediments or abundant volcanic fragments are present in the Tertiary. Plate 2 shows the thickness of Quaternary units on geologic sections across the study area.

Quaternary sediments in the Carson Desert record the history of ancient Lake Lahontan as it grew and receded over more than 1 million years. Sediments were deposited during three distinct times in the Quaternary: early Lake Lahontan, late Lake Lahontan, and post-Lake Lahontan. Exposures of sediments from early Lake Lahontan time are rare in the Carson Desert, but the unit is commonly encountered in wells (Morrison, 1964, p. 98), where thicknesses locally exceed 2,000 ft (Melhorn, [1974?], p. 3-5). Deposition of the lower Lake Lahontan sediments (LLL on pl. 2) in early Lake Lahontan time, which began before $1 \mathrm{Ma}$ and ended about $350 \mathrm{ka}$, records two deep-lake cycles and two shallow-lake cycles (Morrison, 1991, fig. 6). The Paiute
Formation, which consists primarily of alluvial sediments, was deposited while Lake Lahontan was at a low stand and is the youngest of the lower Lake Lahontan sediments (Morrison, 1964; 1991c).

Sediments of the Lahontan Valley Group (ULL on pl. 2) were deposited in late Lake Lahontan time, from about 350 to $7 \mathrm{ka}$, and overlie the Paiute Formation (Morrison, 1991, fig. 6). The upper Lake Lahontan sediments deposited in late Lake Lahontan time consist of lacustrine and subaerial deposits that record a series of five deep-lake cycles alternating with partial or complete lake recession (Morrison, 1964 , p. 28; Morrison, 1991 , p. 297-299). The generalized distribution of the sediments of the Lahontan Valley Group in the southern Carson Desert can be seen on plate 3 and figure 3 , which show upper Quaternary sediments and ancient river channels (Morrison, 1964, pls. 3-6, 11). Major formations that make up the Lahontan Valley Group are the Eetza, Wyemaha, and Sehoo Formations (Morrison, 1964, p. 28). The Eetza and Sehoo Formations consist primarily of deep-lake sediments, whereas the Wyemaha Formation consists primarily of shallowlake and subaerial sediments (Morrison, 1991, p. 297-299). In the subsurface, the Lahontan Valley Group (pls. 1 and 2) is thought to be 185 to $1,300 \mathrm{ft}$ thick near the town of Stillwater (Union 76 Geothermal Division, [1979?]; Union Oil Company of California, 1981; Morgan, 1982, p. 24-27), $500 \mathrm{ft}$ thick in the northeastern Carson Sink area (Melhorn, [1974?], p. 2), about $600 \mathrm{ft}$ thick west of Fallon (Horton, 1978, p. 14, 20-22), and from 100 to more than 1,000 ft thick in the Carson Lake area (Garside and others, 1988, p. 10-11; Dames and Moore, 1988, fig. 4-9).

The oldest unit of the Lahontan Valley Group is the Eetza Formation, which records two deep-lake cycles (Morrison, 1964, p. 99). Deposition of the Eetza Formation is estimated to have begun about 350 $\mathrm{ka}$ and lasted until about $130 \mathrm{ka}$; the Eetza Formation overlies the basalt of Rattlesnake Hill (Morrison, 1964 , p. 23; 1991c, p. 297). The Eetza Formation consists primarily of deep-lake, deltaic, alluvial-fan, and shoreline deposits (Morrison, 1964, p. 28-34, 99). Deep-lake facies, primarily clay beds, of the Eetza Formation are not exposed but have almost certainly been penetrated by drillholes on the floor of the Carson Desert (Morrison, 1964, p. 33; Melhorn, [1974?], p. 2-3; Dames and Moore, 1988, fig. 4-9). A delta of the Carson River, which formed $12 \mathrm{mi}$ west of Fallon during this time, consists of sand, gravel, silt, and minor clay (Morrison, 1964, p. 99). Coarse alluvial-fan and shoreline facies occur primarily around the perimeter of the Carson Desert (Morrison, 1964,p. 28-34). The Eetza Formation was 


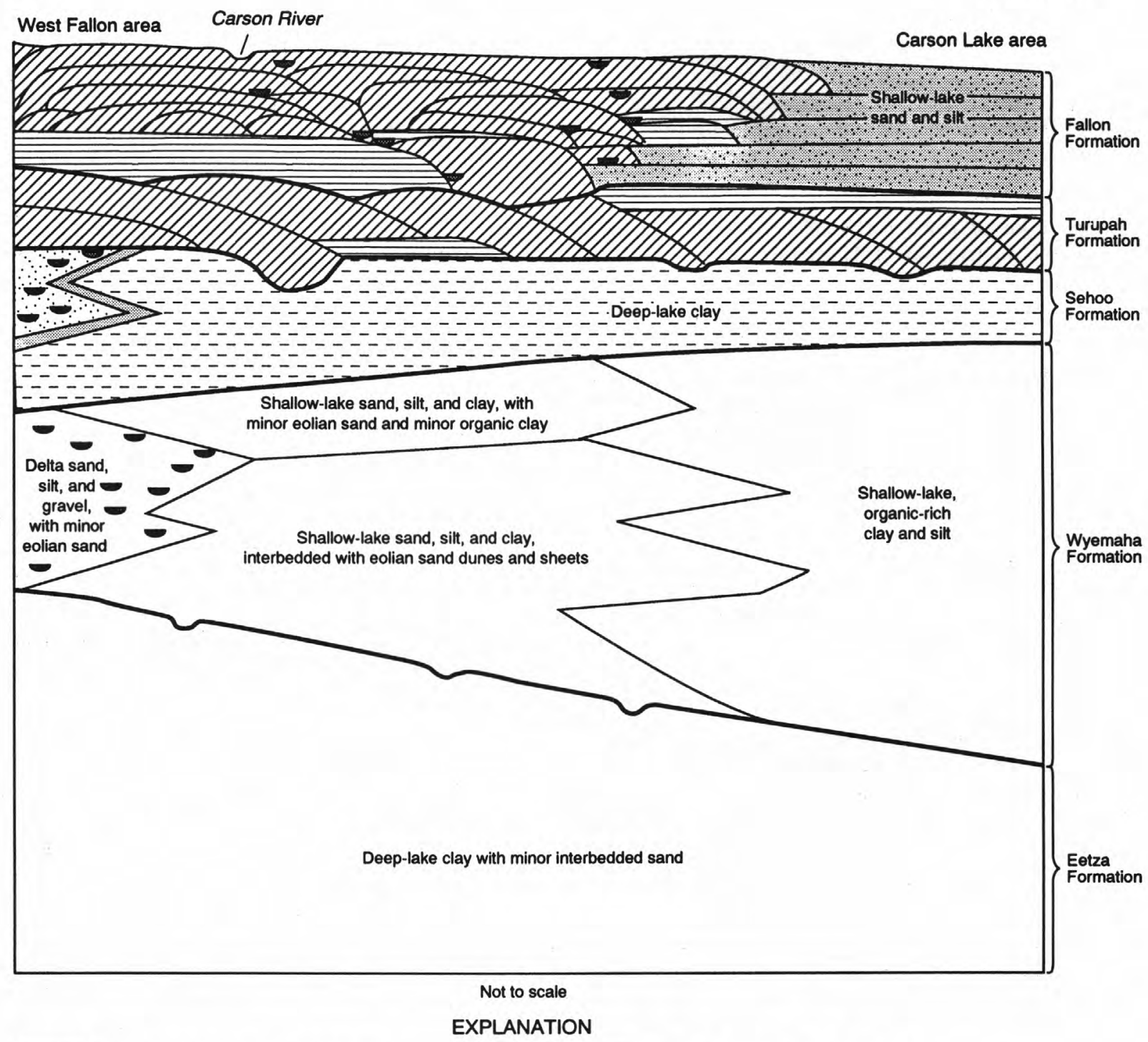

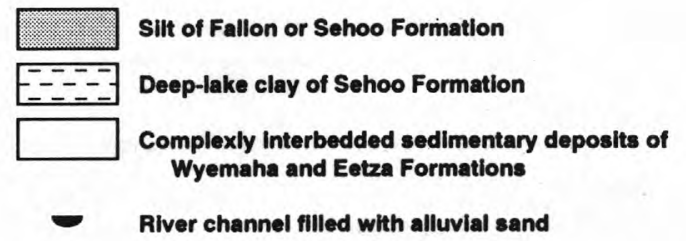

Figure 3. Schematic geologic section showing relation between sedimentary deposits of Quaternary age in FallonCarson Lake area. (Data from Morrison, 1959; 1964). 
deposited simultaneously with the Tahoe glaciation in the Sierra Nevada (Birkeland, 1968, table 2). The Eetza Formation was deposited during the stormiest part of ancient Lake Lahontan history (Morrison, 1964, p. 99); shoreline deposits of the Eetza Formation are coarser grained and are associated with deeper erosion into pre-existing topography than any units that were deposited after the Eetza (Morrison, 1964, p. 99).

The Wyemaha Formation, which is widely exposed in the Carson Desert (pl. 3), was deposited after ancient Lake Lahontan receded during a relatively long period when the Carson Desert was nearly or completely dry (Morrison, 1964 , p. $34,39,99$ ). The Wyemaha Formation, which was deposited from 130 to $35 \mathrm{ka}$, is thought to have formed during the interglacial period between the Tahoe and Tioga glaciations in the Sierra Nevada (Birkeland, 1968, p. 477; Morrison and Davis, 1984b, fig. 2-3). The maximum thickness of the Wyemaha Formation is unknown but exceeds $150 \mathrm{ft}$ in the subsurface (Morrison, 1964, p. 38).

The Wyemaha Formation consists of eolian and alluvial sediments in the highlands (above 3,900 to $4,100 \mathrm{ft}$ in altitude), whereas in the lowlands, it consists of shallow-lake and minor interbedded eolian sediments (Morrison, 1964, p. 34, pls. 3-6). Eolian sand deposits of the Wyemaha Formation are 0 to 100 $\mathrm{ft}$ thick, alluvial sand and gravel deposits of the Wyemaha Formation are 2 to $10 \mathrm{ft}$ thick, and shallow-lake sand, silt, and clay deposits in the Wyemaha Formation are as thick as $160 \mathrm{ft}$ (Morrison, 1964, p. $36,148-151$ )

The shallow-lake sediments are the most widespread of the Wyemaha Formation facies. Sand of the shallow-lake facies is thickest in the western part of the study area and is as much as $50 \mathrm{ft}$ thick near the town of Stillwater (Morrison, 1964, p. 37; Morgan, 1982, p. 26). Where the shallow-lake sand of the Wyemaha Formation is exposed, the water table is generally within a few feet of the surface (Morrison, 1964, p. 36).

On the basis of subsurface data (Morrison, 1959) from more than 100 locations in the southern Carson Desert (including data from Stabler, 1904, and Lee and Clark, 1916), Morrison (1964, p. 37) concluded that the uppermost 5 to $30 \mathrm{ft}$ of the Wyemaha Formation is generally unconsolidated, well-sorted lake sand. On the Carson River delta that formed just west of Fallon between 130 and $7 \mathrm{ka}$, this uppermost sand consists primarily of clean, clastic grains with little or no organic material. Away from the delta, toward the low-lying areas of the Carson Desert, the sand grades laterally into silt, clay, and organic material in the shallow-lake deposits (fig. 3). As a result of this lateral change, the uppermost Wyemaha Formation consists of highly organic black clay and silt in the Carson Lake, eastern Carson Sink, Stillwater Slough, Stillwater Marsh, and Eightmile Flat areas (Morrison, 1964, p. 37).

In the subsurface, the uppermost Wyemaha Formation shallow-lake sand beds are generally underlain by a thick zone (possibly more than $100 \mathrm{ft}$ ) of alternating thin beds (about $1 \mathrm{ft}$ thick) of sand and clay (Morrison, 1964, p. 37, 148-149). Where the uppermost Wyemaha is highly organic black clay and silt, clay of the Sehoo Formation can easily be distinguished from the Wyemaha Formation in drillholes (Morrison, 1964, p. 38, 43). The clay of the Sehoo Formation is commonly gray and contains very little organic material. This sequence of gray clay of the Sehoo Formation overlies black organic-rich clay of the Wyemaha Formation in the Carson Lake, Stillwater Slough, Stillwater Marsh, Eightmile Flat, and southeast Carson Sink areas (Morrison, 1964, p. 38). The highly organic black clay and silt beds of the Wyemaha Formation contain small amounts of natural gas in the Stillwater Marsh and Carson Lake areas (Morrison, 1964, p. 37; Morgan, 1982, p. 26).

The Sehoo Formation overlies the Wyemaha Formation and consists primarily of deep-lake sediments, which are widely exposed throughout the Carson Desert (Morrison, 1964, p. 41). In the lowlands, exposed deep-lake and shoreline sediments are as much as $68 \mathrm{ft}$ thick and consist of clay with small amounts of silt, sand, tufa, limestone, and volcanic ash. In the highlands, exposed shoreline sediments, which are at least $65 \mathrm{ft}$ thick, consist of sand and gravel (Morrison, 1964, p. 51, 59, 61-62). The lower part of the Sehoo Formation and the Wyemaha Formation (pl. 3) are interbedded with basaltic tuffs at Upsal Hogback (Davis, 1978, p. 41). The basaltic tuffs were not mapped as part of the Wyemaha or Sehoo Formations by Morrison (1964). On plate 3, consolidated basaltic tuff of Upsal Hogback is shown as consolidated volcanic rock, whereas the unconsolidated basaltic sand that is exposed around the tuff is included as part of the Wyemaha Formation because of its similar permeability and age.

The Sehoo Formation records the last three deeplake cycles of ancient Lake Lahontan (Morrison, 1964, p. 41). On the basis of numerous radiometricage determinations, deposition of the Sehoo Formation began about $40 \mathrm{ka}$ and ended about $7 \mathrm{ka}$ (Broecker and Orr, 1958; Benson and Thompson, 1987, p. 69; Davis, 1978, table 8). The Sehoo Formation is believed to be correlative with the Tioga glaciation in the Sierra Nevada, which reached its maximum between 22 and 12 ka (Birkeland, 1968; Curry, 1969). 
The Sehoo Formation is subdivided into four members that differ primarily in the lithology and distribution of gravel and tufa (Morrison, 1964, p. 41-65). From oldest to youngest, these units are the lower, thinolite, dendritic, and upper members of the Sehoo Formation. The three oldest members are largely deep-lake clay (locally bentonitic), whereas the youngest (upper) member is primarily shallowlake sand (Morrison, 1964, p. 43, 57). The four depositional episodes appear to have been separated by periods of nearly complete desiccation (Davis, 1978, p. 8).

The lower member of the Sehoo Formation consists of lacustrine clay, silt, sand, gravel, tufa, and volcanic ash (Morrison, 1964, p. 51). In the highlands, the lower member consists mainly of wellsorted sand with small amounts of gravel and is as much as $50 \mathrm{ft}$ thick; in the lowlands, the lower member consists mainly of clay and silt and is as much as $30 \mathrm{ft}$ thick, with the maximum thicknesses on a delta that was formed just west of Fallon by the Carson River (Morrison, 1964, p. 51, 57, 59). Clay of the lower member is generally much thicker than any of the other members; it is 3 to $15 \mathrm{ft}$ thick, with maximums in the eastern lowlands of the Carson Desert (Morrison, 1964, p. 59). This lower member clay is essentially nonsaline and noncalcareous (Morrison, 1964, p. 59). Sand of the lower member, which is reworked from the Wyemaha Formation on the ancient Carson River delta and in the highlands, is more widespread than gravel (Morrison, 1964, p. 57).

The thinolite member of the Sehoo Formation, which is consistently less than about $5 \mathrm{ft}$ thick, consists of lake clay, silt, and a type of tufa called thinolite (Morrison, 1964, p. 59). The dendritic member, like the lower member, consists of wellsorted sand and small amounts of gravel in the highlands, clay in the lowlands, and tufa along the ancient shorelines (Morrison, 1964, p. 61). The sand of the dendritic member is as much as $20 \mathrm{ft}$ thick on the Carson River delta west of Fallon, but elsewhere it is generally less than $5 \mathrm{ft}$ thick (Morrison, 1964, p. 61). The clay of this member is less silty, more calcareous, and more saline than the clay of the lower member (Morrison, 1964, p. 61). The dendritic member has been eroded from large areas in the central Carson Desert (Morrison, 1964, p. 62).

The upper member of the Sehoo is generally 1 to $5 \mathrm{ft}$ thick but is as thick as $16 \mathrm{ft}$ in places (Morrison, 1964, p. 62). Sand is more widespread than clay or gravel in the upper member, particularly where sediments of the upper Sehoo formed deltas west and north from Fallon (Morrison, 1964, p. 62). The sand is thinner than in older deltaic and shoreline deposits but is considerably thicker than any lake-sand deposits of post-Lake Lahontan time (Morrison, 1964, p. 62). Plate 3 shows some of the channels formed by the Carson River during and after deposition of the upper member of the Sehoo Formation.

Two ancient Carson River deltas that are part of the upper member of the Sehoo contain relatively voluminous sand deposits (Morrison, 1964, p. 62-63). The west delta extends about $10 \mathrm{mi}$ from Soda Lake eastward to Oles Pond and $5 \mathrm{mi}$ northward and southward from Fallon (pls. 1 and 3). The Indian Lakes delta, about $10 \mathrm{mi}$ northeast of Fallon under Indian Lakes (pls. 1 and 3), is about 4 mi wide and $6 \mathrm{mi}$ long (Morrison, 1964, p. 62). The sand of the upper member grades laterally away from the deltas into silt and then clay (Morrison, 1964, p. 63). In deposits of the two deltas, the silty transition zone from beach sand to deep-lake clay commonly exceeds $1 \mathrm{mi}$ in width and is 2 to $5 \mathrm{ft}$ thick (Morrison, 1964, p. 63). Elsewhere, near ancient shorelines, the silty transition zone is less than $0.5 \mathrm{mi}$ wide and less than $1 \mathrm{ft}$ thick. Clay of the upper member is thickest (as much as $4 \mathrm{ft}$ ) near Indian Lakes and from the Stillwater Slough to the Carson Lake area (Morrison, 1964, p. 63).

The largely unconsolidated Soda Lake volcanicsand complex, $6 \mathrm{mi}$ northwest of Fallon (pls. 1 and 3), was deposited simultaneously with the Sehoo Formation (probably between 11 and $6 \mathrm{ka}$ ). The complex was not mapped as part of the Lahontan Valley Group by Morrison (1964, pl. 6) because of its volcanic origin, but is included with the Sehoo Formation on plate 3 because of its similar permeability and age. The craters that contain Soda Lakes were formed by explosive volcanism and are now filled with water (Morrison, 1964, p. 71, 101).

Post-Lake Lahontan sediments (fig. 3 ) overlie the Sehoo Formation and are thinner and more restricted in distribution than the upper Lake Lahontan sediments (Morrison, 1964, p. 79). Post-Lake Lahontan sediments have been divided into two units, older to younger: Turupah Formation and Fallon Formation (Morrison, 1964, p. 75, 79; 1991c, 299-300). The Turupah Formation was deposited between about 7 and $4 \mathrm{ka}$ (Holocene). Davis (1978, p. 56) concluded that the Turupah might be considered part of the Fallon Formation rather than a distinct formation. The Turupah Formation was deposited when ancient Lake Lahontan was completely dry for an extended period of time (Morrison, 1964, p. 102). The unit primarily consists of eolian sand as thick as $30 \mathrm{ft}$, with local alluvial sand as thick as $15 \mathrm{ft}$, and volcanic ashbeds less than 1 in. thick (Morrison, 1964, p. 76-78). Morrison (1964, p. 102) estimates that half a cubic mile of sediment was deflated from the 
Carson Desert while the Turupah Formation was being deposited-during an extremely windy and dry period. Deflation was most intense in the western lowlands, where it locally removed the Sehoo Formation and part of the Wyemaha Formation (Morrison, 1964, p. 102).

The Fallon Formation, which overlies the Turupah Formation, consists of eolian, alluvial, deltaic, and shallow-lake sediments (Morrison, 1964, p. 79-84, table 7). The Fallon Formation records a series of five shallow-lake cycles (depths, $20-85 \mathrm{ft}$ ) in the Stillwater Marsh to the Stillwater Slough area and in the Carson Lake area during the last 4,000 or 5,000 years (Morrison, 1964, p. 103; Davis, 1978, p. 8; 1982, p. 67). Each of the five lakes was smaller than the preceding lake (Morrison, 1964, p. 86; pl. 11). After the first two Fallon lake cycles, the Stillwater Slough to the Stillwater Marsh area and Carson Lake area became separate bodies of water (Morrison, 1964, p. 103-104; pl. 11). The last of the five lakes dried up just before Euro-Americans entered the area in the 1800's (Davis, 1978, p. 8).

Each of the five lake cycles is preserved as a separate geologic unit that contains mainly deltaic sand; lake sand, silt, and clay; and contemporaneous eolian sand, and small amounts of lake gravel, tufa, and volcanic ash (Morrison, 1964, table 7). Each of the lake units is generally 2 to $4 \mathrm{ft}$ thick, but ranges from less than 1 to rarely $10 \mathrm{ft}$ thick (Morrison, 1964, table 7). Sediments deposited during interlake cycles (between the main lacustrine cycles) consist of beds of eolian sand, alluvium, and very shallow lake sediments less than $5 \mathrm{ft}$ thick (Morrison, 1964, table 7).

Plate 3 shows exposed channels mapped by Morrison (1964) and Dollarhide (1975). The channels, which locally cut older sediments, were formed by the Carson River during deposition of the Fallon, Turupah, and upper Sehoo Formations. Most of these channels are contemporaneous with the Fallon Formation. During each lake cycle of the Fallon Formation, the Carson River built two or three deltas out into the lake(s); these deltas formed in different places during successive cycles (Morrison, 1964, p. 87 and table 7). The Carson Lake and Stillwater Marsh areas received sediment throughout most of the time the Fallon Formation was forming. In the center of each of these areas, the Fallon Formation consists almost entirely of lake silt, sand, and clay (Morrison, 1964, p. 87). Carson Sink, which is the lowest part of the Carson Desert today, contains almost no sediments of the Fallon Formation (Morrison, 1964, p. 87). This indicates either that the Carson River rarely drained into Carson Sink during deposition of the Fallon Formation, that sediments of the Fallon Formation were removed by deflation, or both (Morrison, 1964, p. 87).

\section{SURFACE WATER}

\section{Description of Surface-Water Flow System}

Surface-water flow to the Carson Division of the Newlands Project is controlled at Lahontan Reservoir (inset, pl. 1), which has a maximum storage capacity of about 317,000 acre-ft (Bureau of Reclamation, 1992b, p. 35). The Truckee Canal is about $32 \mathrm{mi}$ long, extending from Derby Diversion Dam on the Truckee River to Lahontan Reservoir, and has an average flow near Hazen of about 143,000 acre-ft/yr for the period from 1966 to 1991 (USGS gaging station, Truckee Canal near Hazen, pl. 1; Garcia and others, 1992, p. 330). Flow in the main stem of the Carson River above Lahontan Reservoir averaged about 266,000 acre-ft/yr from 1911 to 1991 (USGS gaging station, Carson River near Fort Churchill, inset, pl. 1; Garcia and others, 1992, p. 155). Outflow from Lahontan Reservoir measured in the Carson River below the reservoir averaged about 385,000 acre-ft/yr for the period from 1966 to 1991 (USGS gaging station, Carson River below Lahontan Reservoir, pl. 1; Garcia and others, 1992, p. 159).

Some water released from Lahontan Reservoir is diverted for irrigation at Rock Dam Ditch, which is upstream from both the gage recording outflow from the reservoir and the Carson Diversion Dam. Most of the released water is diverted at the Carson Diversion Dam $5 \mathrm{mi}$ below the reservoir into the T-Line and V-Line Canals for irrigation of lands north (20 percent of total Project lands) and lands south (65 percent of total Project lands) of the Carson River (Bureau of Reclamation, 1986, p. IV-41). Regulating reservoirs--Sheckler, S-Line, Old River, Harmon, and Stillwater Point--further control flow through the extensive canal system and to wetlands. Stillwater Point Reservoir and Indian Lakes are managed by the U.S. Fish and Wildlife Service to control inflow to wetland areas.

Irrigated lands in the Carson Division are divided into 10 subdistricts, each supplied by one or two systems of distribution canals. About $340 \mathrm{mi}$ of canals and laterals serve an estimated 1,500 farm headgates, and about $25 \mathrm{mi}$ of the canals and laterals are lined with concrete (Carol Grenier, Bureau of Reclamation, oral commun., 1993). About $350 \mathrm{mi}$ of open drains route irrigation return flow and shallow 
ground-water seepage to the Carson River and wetlands at Stillwater WMA and Carson Lake. Subsurface tile drains probably make up less than 5 percent of the drain system (Peggy A. Hughes, U.S. Soil Conservation Service, oral commun., 1993).

Routing of surface water in the distribution system is complex. It changes daily during the irrigation season to meet delivery demands, and also changes from year to year. Deliveries to TCID headgates are managed and measured by TCID. Headgates for individual fields are at varying distances downstream from TCID headgates. Thus, additional losses can take place between the point where delivery is measured and where the water is applied to irrigated fields. Runoff from fields flows into drains or sometimes returns to the canal from which the irrigation water came and is redistributed. Drain flow can be routed to regulating reservoirs and blended with "prime" water (water in main canals and laterals containing minimal return flow) for redistribution, routed to main canals and blended for redistribution, or routed directly to the wetlands. Drains commonly are near canals, and subsurface seepage from the canal to the drain can take place. Outflow from the distribution system is a mixture of (1) release of prime water, (2) runoff, or return flow, from irrigated fields, and (3) ground water that has seeped into the drain system.

Outflow from the main area of irrigated lands is used to irrigate pasture lands within both the Stillwater WMA and the Carson Lake areas and to maintain wetland habitat.

\section{Surface-Water Budget}

The present-day hydrologic system in the Carson Desert is dominated by the effects of 90 years of surface-water irrigation. Estimated recharge from precipitation is small compared with the volume of surface water moving through the basin.

In this section, reported estimates of the volume of surface water transmitted and consumed through the irrigation system are presented to gain insight regarding the distribution of water and the relative importance of processes that affect the overall hydrologic budget. The values may not be representative of conditions that will prevail under 1988 OCAP regulations. Potential effects of the OCAP regulations will be discussed in a later section of this report.

Although some components of the surface-water budget are measured or can be calculated from measured values with reasonable accuracy, other components are estimated or have unknown accuracy.

\section{Factors that Affect Estimates of Flow Volumes}

The reports referenced in this section summarize data collected during different time periods with varying amounts of annual flow and categorize and calculate losses in different ways. This results in differences in reported estimates of flow volumes. Some differences exist between values reported for the same time periods at the same locations from records of the USGS, BOR, TCID, and USFWS. Detailed descriptions and evaluations of how the author(s) of each report obtained estimates for flow volumes or resolving differences among those estimates are beyond the scope of this study.

Few studies state whether reported values were calculated using water years (October 1 through September 30), irrigation years (historically, March 15 through November 15), or calendar years (January 1 through December 31). The time frame used could contribute to differences in reported estimates of flow volumes. It is assumed, unless stated otherwise in the cited report, that the calendar year was used in reported estimates; unless otherwise noted, the calendar year is used in this report.

Large variations in annual runoff reported for different time periods can cause variations in the long-term average value. For example, the long-term average flow for the Carson River below Lahontan Reservoir ranged from 415,900 acre-ft/yr for water years 1966-86 (Pupacko and others, 1988, p. 144) after the wet years of the mid 1980's, to 375,100 acre-ft/yr for water years 1966-92 (Hess and others, 1993 , p. 164) after an extended drought. Thus, reported average flows at the same site using different periods of record can be expected to differ greatly.

In many of the studies, measured or "known" quantities of water at different points in the system were used to compute an "unknown" quantity by subtracting one value from the other, assuming a net balance in the hydrologic system. Thus, the accuracy of the calculated values depends on the accuracy of the assumed "known" values.

When records of the USGS for streamflow of the Carson River below Lahontan Reservoir are listed as "good" (Garcia and others, 1992, p. 18, 159), it means that 95 percent of the daily values of flow are assumed to be within 10 percent of their true value. Thus, the average discharge of $384,700 \mathrm{acre}-\mathrm{ft} / \mathrm{yr}$ for water years 1966-91 at that site has an uncertainty of about 38,000 acre-ft/yr. When records for USGS gaging stations recording outflow from irrigated areas are reported as "fair" or "poor," fair means that 95 percent of the daily values at those sites are within 15 percent of the true value, and poor means that 95 percent of the daily values may differ by more than 
15 percent from their true values (Garcia and others, 1992 , p. $18,160,165,167,168)$. The accuracy of other gaged and estimated flow to wetland areas is estimated to be within 20 percent of the true values, at best (Norman A. Saake, U.S. Fish and Wildlife Service, written commun., 1993).

Some gaging stations operated by TCID and the BOR are reported by the Bureau (1992b, p. 5) to have preliminary ratings that cannot yet predict flows with good accuracy. Estimates of gage accuracy are not available.

Headgate deliveries to farms have been reported to be underestimated by an average of about 15 percent (Bureau of Reclamation, 1990, p. 32). Prior to 1986 , flows at farm headgates were rounded down to the nearest cubic foot per second, thus underestimating delivered flow (Bureau of Reclamation, 1992b, p. 22). Also, delivery "start and stop times" to farm headgates were rounded to the nearest hour about 70 percent of the time prior to 1988 . This creates an additional source of potential error in reporting the volume of water delivered to farms. However, there is no indication that rounding of delivery times resulted in consistently under- or overestimated actual flow volumes (Bureau of Reclamation, 1992b, p. 23).

Thus, when the "known" headgate delivery is subtracted from the "known" releases from Lahontan Reservoir to obtain the "unknown" value for conveyance loss, the resulting value is uncertain. Also, small differences in estimated rates such as consumptive use and farm efficiency, applied to thousands of acres of land and acre-feet of water, can make large differences in the resulting volume estimates. For the above reasons, an inherent uncertainty is associated with each estimate discussed below. Recognizing these uncertainties, the reported values are used as the best available estimates.

Finally, changes in operating procedures during the Newlands Project have affected the magnitude of some values over time, and new procedures outlined by the final OCAP will no doubt further change the magnitude of some values.

In the following section, flow volumes averaged over the longest and most recent time period are considered to be the most representative of flow in the Carson Division. The most reliable data available are from about the mid-1960's to 1992. This time period is considered to represent historic conditions. Extended drought conditions since the 1988 OCAP have been in effect have not allowed normal operation of the system as envisioned in the OCAP regulations. For purposes of this report, the drought period from 1988 to 1992 will be considered to represent pre-1988 OCAP conditions.

\section{Estimates of Historical Surface-Water Flow Volumes}

In this section, previously reported estimates of surface-water flow volumes are summarized, and estimates thought to be most representative of historical (pre-1988 OCAP) conditions were selected. Surface-water volumes from reports summarized in this section were obtained from records of the USGS, TCID, and BOR; few studies involved collection of detailed surface-water measurements. Notable exceptions are as follows: studies summarized by Guitjens and Mahannah (1976); a study by the Bureau of Reclamation (1971); the study by CH2M Hill (1973), which used detailed inflow and outflow measurements at three representative areas to obtain estimates for the entire Newlands Project, and the study by MacDiarmid (1988), which used detailed flow measurements collected by TCID during the 1985 irrigation season.

Table 1 shows annual surface-water flows obtained from records of the USGS, BOR, TCID, and USFWS from 1975 to 1992 , that are considered to represent the best available measurements and estimates for annual surface-water flow volumes through the Carson Division for that time period.

Table 2 summarizes the surface-water budget by showing the reported range of average annual flow volumes, the selected representative estimates of flow and their relative accuracy, and net volumes of flow through the Carson Division. Figure 4 depicts the flow volumes using arrows whose widths are proportional to the volume of flow. In the following discussion, the time period for which an estimate of surfacewater volume was calculated will be enclosed by brackets-for example [1930-70]-for purposes of comparison. CH2M Hill (1973) and Mahannah and others (1975) report values summarized for the entire Newlands Project (both Truckee and Carson Divisions). Their values are presented in the text for purposes of comparison with reported flows in the Carson Division. Reported flows not labeled as reported for the entire Newlands Project are for the Carson Division only. Because of the uncertainties inherent in the volume estimates, the representative estimates will be reported to the nearest 10,000 acre$\mathrm{ft} / \mathrm{yr}$.

Measured values listed in table 2 include (1) values recorded at stream-gaging stations operated by the USGS, BOR, or TCID, (2) values measured and estimated at farm headgates by TCID or BOR, and, (3) values obtained from measured precipitation rates applied to areas that can be determined accurately. Values listed as having uncertain accuracy were 
Table 1. Measured and estimated surface-water flows in Carson Division of Newlands Project, 1975-92

[All values in acre-feet per year (rounded). Abbreviation: WMA, Wildlife Management Area]

\begin{tabular}{|c|c|c|c|c|c|c|c|c|}
\hline Calendar year & $\begin{array}{c}\text { Release from } \\
\text { Lahontan } \\
\text { Reservoir }^{1}\end{array}$ & $\begin{array}{l}\text { Deliveries to } \\
\text { farm headgates }\end{array}$ & $\begin{array}{c}\text { Loss above } \\
\text { farm } \\
\text { headgates }^{3}\end{array}$ & $\begin{array}{c}\text { Carson River } \\
\text { above Carson } \\
\text { Sink }\end{array}$ & $\begin{array}{c}\text { Flow to } \\
\text { Stillwater WMA }\end{array}$ & $\begin{array}{c}\text { Flow to Carson } \\
\text { Lake }^{6}\end{array}$ & Total outflow ${ }^{7}$ & $\begin{array}{c}\text { Total loss below } \\
\text { Lahontan } \\
\text { Reservoir }^{8}\end{array}$ \\
\hline 1975 & 397,000 & 195,000 & 202,000 & 13,600 & 79,000 & 38,000 & 131,000 & 267,000 \\
\hline 1976 & 263,000 & 147,000 & 117,000 & 2,900 & 40,000 & 40,000 & 83,000 & 180,000 \\
\hline 1977 & 211,000 & 110,000 & 100,000 & 140 & 19,000 & 59,000 & 78,000 & 133,000 \\
\hline 1978 & 336,000 & 184,000 & 152,000 & 4,900 & 45,000 & 66,000 & 115,000 & 221,000 \\
\hline 1979 & 397,000 & 198,000 & 200,000 & 23,800 & 56,000 & 77,000 & 158,000 & 240,000 \\
\hline 1980 & 493,000 & 191,000 & 302,000 & 102,000 & 71,000 & 84,000 & 257,000 & 236,000 \\
\hline 1981 & 324,000 & 192,000 & 132,000 & 1,200 & 56,000 & 72,000 & 129,000 & 194,000 \\
\hline 1982 & 538,000 & 167,000 & 371,000 & 139,000 & 149,000 & 94,000 & 382,000 & 156,000 \\
\hline 1983 & 785,000 & 178,000 & 607,000 & 335,000 & 162,000 & 104,000 & 600,000 & 184,000 \\
\hline 1984 & 471,000 & 197,000 & 274,000 & 99,300 & 93,000 & 66,000 & 259,000 & 212,000 \\
\hline 1985 & 347,000 & 193,000 & 154,000 & 3,900 & 62,000 & 59,000 & 125,000 & 222,000 \\
\hline 1986 & 579,000 & 206,000 & 373,000 & 109,000 & 102,000 & 59,000 & 270,000 & 309,000 \\
\hline 1987 & 325,000 & 186,000 & 139,000 & 4,800 & 56,000 & 53,000 & 114,000 & 212,000 \\
\hline 1988 & 234,000 & 145,000 & 89,000 & 4,900 & 36,000 & 35,000 & 76,000 & 158,000 \\
\hline 1989 & 318,000 & 196,000 & 122,000 & 6,100 & 42,000 & 41,000 & 89,000 & 229,000 \\
\hline 1990 & 255,000 & 148,000 & 107,000 & 4,700 & 39,000 & 32,000 & 76,000 & 180,000 \\
\hline 1991 & 179,000 & 98,000 & 80,000 & 2,900 & 19,000 & 21,000 & 43,000 & 136,000 \\
\hline 1992 & 118,000 & 63,000 & 55,000 & 1,500 & 9,100 & 8,800 & 19,000 & 99,000 \\
\hline Average (rounded) & 370,000 & 170,000 & 200,000 & 50,000 & 60,000 & 60,000 & 170,000 & 200,000 \\
\hline
\end{tabular}

1 Data from U.S. Geological Survey, 1975-92, Carson River below Lahontan Reservoir. Includes gaged flow of Rock Dam diversions from Truckee-Carson Irrigation District for 1985-92, and estimated flow of Rock Dam diversions for 1975-84.

2 Data from Truckee-Carson Irrigation District (Willis Hyde, Truckee-Carson Irrigation District, written commun., 1993).

3 Release from Lahontan Reservoir, minus deliveries to farm headgates.

4 Data from U.S. Geological Survey: Carson River below Fallon, 1975-84; Carson River at Tarzan Road near Fallon, $1985-92$.

5 Data from U.S. Geological Survey and Truckee-Carson Irrigation District gaging stations; summarized for 1975-86 by Norman A. Saake (U.S. Fish and Wildlife Service, written commun., 1993) and for 1987-92 by Willis Hyde (written commun., 1993).

6 Data from U.S. Geological Survey, Truckee-Carson Irrigation District, and Bureau of Reclamation gaging stations; estimated for $1975-86$ by Norman A. Saake (written commun., 1992) and summarized for $1987-92$ by Willis Hyde (written commun., 1993).

7 Flow to Stillwater Wildlife Management Area and Carson Lake, plus Carson River above Carson Sink (rounded).

8 Release from Lahontan Reservoir, minus total outflow. 
Table 2. Surface-water budget for Carson Division of Newlands Project

[Values in thousands of acre-feet per year. Minus sign, loss of flow volume; ?, representative value not assigned; >, greater than]

\begin{tabular}{|c|c|c|c|}
\hline Budget component & $\begin{array}{l}\text { Reported } \\
\text { range }^{1}\end{array}$ & $\begin{array}{c}\text { Representative } \\
\text { estimate }^{2}\end{array}$ & $\begin{array}{l}\text { Surface-water } \\
\text { losses avail- } \\
\text { able for out- } \\
\text { flow to } \\
\text { wetlands }\end{array}$ \\
\hline Lahontan Reservoir releases & $332-403$ & $370 *$ & \\
\hline Precautionary drawdown and spill from reservoir & $29-44$ & $-30 *$ & 30 \\
\hline Net diversions for irrigation & $300-380$ & $340 *$ & \\
\hline \multicolumn{4}{|l|}{ Conveyance losses: } \\
\hline Operational spills from distribution system & $50-65$ & $-50 * *$ & 50 \\
\hline Seepage loss & $52-105$ & $-100 * *$ & 100 \\
\hline Evaporation & $20-25$ & $-20 *$ & \\
\hline Total loss & $143-175$ & $-170 * *$ & \\
\hline Net available for headgate delivery & $166-195$ & $170 *$ & \\
\hline Precipitation on irrigated lands & $18-23$ & $20 *$ & \\
\hline Total available for on-farm use & & $190 *$ & \\
\hline On-farm loss & $48-70$ & $-60 * *$ & 60 \\
\hline Net available for consumptive use & & $130 * *$ & 240 \\
\hline \multicolumn{4}{|l|}{ Consumptive use requirement on irrigated lands: } \\
\hline Crop use & $125-230$ & $?$ & \\
\hline Non-crop use & $11-20$ & $?$ & \\
\hline Total use & $136-250$ & $-180 *$ & \\
\hline Deficit & & $-50 * *$ & \\
\hline Ground-water use & $17-87$ & $3_{50} * *$ & -50 \\
\hline Net available for flow to wetlands & & $0 * *$ & 190 \\
\hline Outflow to wetlands and Carson Sink & $146-188$ & $170 *$ & \\
\hline Precipitation on wetlands & 21 & $20 *$ & \\
\hline Net available for consumptive use at wetlands & & $190 *$ & \\
\hline Non-crop consumptive use and evaporation at wetlands & $149-213$ & $>210 * *$ & \\
\hline
\end{tabular}

1 Rounded to the nearest 1,000 acre-feet per year.

2 Rounded to the nearest 10,000 acre-feet per year. Single asterisk denotes measured value; double asterisk denotes estimated value of uncertain accuracy.

3 Representative estimate is amount required from surface-water losses to meet consumptive use. 


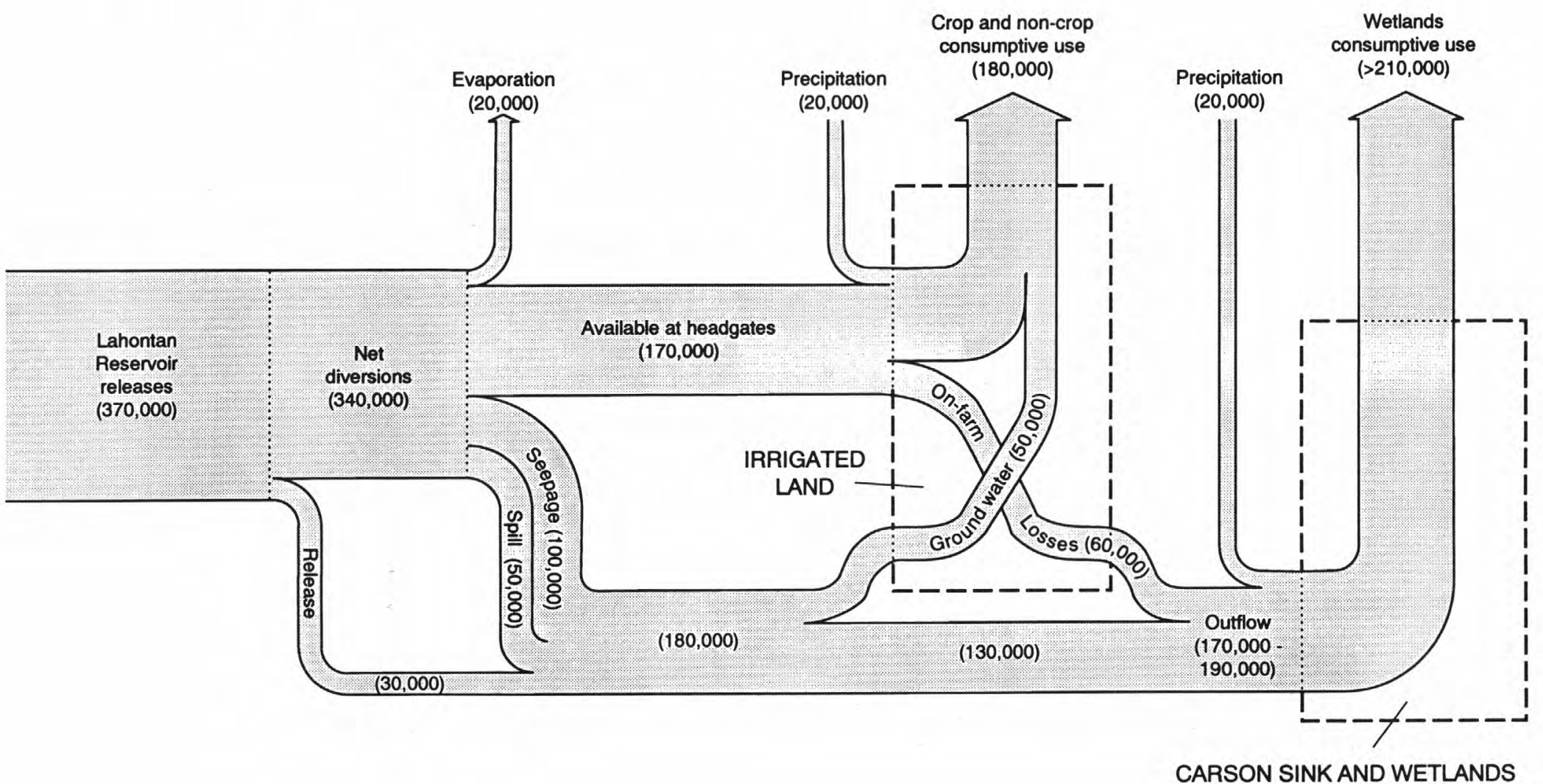

Figure 4. Historical distribution of surface water in Carson Division. Volume estimates are in acre-feet per year (rounded); >, greater than. 
obtained indirectly from estimated or undocumented rates from measurements of local conditions on small plots within the Carson Division and over a short period of time.

Reported average releases from Lahontan Reservoir include:

- 332,000 acre-ft/yr [1987] (Bureau of Reclamation, 1987a, p. 1-8);

- 346,000 acre-ft/yr [1970-79] (Brown and others, 1986, p. 30);

- 370,000 acre-ft/yr [1975-92], table 1 , this report;

- 374,000 acre-ft/yr [1972-91] (Pahl, 1992, table 1);

- 384,700 acre-ft/yr [1967-91 water years] (Garcia and others, 1992, p. 159);

- 400,000 acre-ft/yr [1930-70] (Clyde-CriddleWoodward, 1971, fig. 2); and

- 403,000 acre-ft/yr [1967-74] (Green and others, 1976, fig. 2).

Reported releases and diversions for the entire Newlands Project are:

- 420,000 acre-ft/yr [1970-73] (Mahannah and others, 1975 , p. 26 ); and

- 465,000 acre-ft/yr [1967-72] (CH2M Hill, 1973, fig. 1).

Whether flow diverted at Rock Dam Ditch is included in many of the reported average values of Lahontan Reservoir releases is not known. Measurements of flow diverted at Rock Dam Ditch began in 1985 and averaged about 4,500 acre-ft/yr [1985-91] (Willis Hyde, TCID, written commun., 1992). The gaged flow from 1985 to 1991 diverted at Rock Dam Ditch and measured at the Carson River below Lahontan Reservoir were used to estimate diversions at Rock Dam Ditch and total releases from Lahontan Reservoir for the period 1975-92 (table 1). The average for total releases is about 370,000 acre- $\mathrm{ft} / \mathrm{yr}$ [1975-92].

The gaged flow at the Carson River below Lahontan Reservoir is reported to average 384,700 acre-ft/yr [1967-91, water years] (Garcia and others, 1992 , p. 159). Assuming an average of 4,500 acre$\mathrm{ft} / \mathrm{yr}$ for diversions at Rock Dam Ditch, an average total of about 390,000 acre-ft/yr was released during water years 1967-91 — an increase of 20,000 acre-ft/yr over the period 1975-92. The best gaged and estimated values are available for outflow to wetland areas from 1975-92. For this reason, the total release for that period, 370,000 acre-ft/yr (table 1) will be used as the representative estimate for historical releases from Lahontan Reservoir (fig. 4, table 2).
Water has been released from Lahontan Reservoir during winter months as precautionary drawdown during years with high runoff to allow ample storage capacity for upstream flood waters. Also prior to 1967, about 40,000 acre-ft/yr was released for winter power generation (Bureau of Reclamation, 1976, p. I-17). Some water released from Lahontan Reservoir during winter months can be stored in regulating reservoirs for use during the irrigation season. However, because the combined storage capacity of regulating reservoirs is only about 17,000 acre-ft (Bureau of Reclamation, oral commun., 1993), the excess flows to wetlands at Stillwater WMA and Carson Lake, or to the Carson Sink during wet years.

Estimates of streamflow lost to precautionary release from the reservoir are:

- 28,900 acre-ft/yr [water years 1967-92] (U.S. Geological Survey, 1968-75 and 1976-93, flow during non-irrigation months);

- 30,000 acre-ft/yr [1930-70] (Clyde-CriddleWoodward, 1971, p. 6); and

- 44,000 acre-ft/yr [1967-74] (Green and others, 1976, fig. 1).

From the entire Newlands project:

- 28,000 acre-ft/yr [1970-73] (Mahannah, 1975, p. 26); and

- 59,000 acre-ft/yr [1967-72] (CH2M Hill, 1973, fig. 1).

Present OCAP regulations place a spring storage limit of 215,000 acre-ft for Lahontan Reservoir (U.S. Department of the Interior, 1988, p. 8), which will reduce the diversion of flow from the Truckee River. In future operation, this will tend to eliminate precautionary release from the reservoir in all but the most extremely wet water years.

A value of 30,000 acre-ft/yr will be used as most representative of historical precautionary release from Lahontan Reservoir (fig. 4, table 2).

Some reports cite a value of total diversions for irrigation. This value is assumed to represent Lahontan Reservoir releases minus precautionary releases. Estimates of total diversions for irrigation vary considerably:

- 299,500 acre-ft/yr [1975-84] (Bureau of Reclamation, 1986, p. IV-50);

- 321,400 acre-ft/yr [1981-91] (Bureau of Reclamation, 1992b, p. 15);

- 350,000 acre-ft/yr [1985] (MacDiarmid, 1988, p. 52);

- 359,000 acre-ft/yr [1967-74] (Green and others, 1976, fig. 1); 
- 370,000 acre-ft/yr [1930-70] (Clyde-CriddleWoodward, 1971, p. 6); and

- 380,000 acre-ft/yr [1901-80] (Barnes and Jorgenson, 1987, p. VI-2).

Subtracting the representative estimate for precautionary release of 30,000 acre-ft/yr from the representative estimate for releases from Lahontan Reservoir of 370,000 acre-ft/yr yields 340,000 acre$\mathrm{ft} / \mathrm{yr}$ (fig. 4, table 2). This value will be used as representative of the historical diversions for irrigation of the Carson Division.

Operational spills from the distribution system are a normal consequence of all open-channel delivery irrigation systems. Estimates of this loss of surface water are:

- 50,000 acre-ft/yr [1930-70] (Clyde-CriddleWoodward, 1971, p. 65); and

- 65,400 acre-ft/yr [1987] (Bureau of Reclamation, 1987a, p. 1-8).

For the entire Newlands Project:

- 50,000 acre-ft/yr [1967-72] (CH2M Hill, 1973, p. 4-4); and

- 88,000 acre-ft/yr [1987] (U.S. Department of the Interior, 1988, p. 5).

Green and others (1976, fig. 1) do not specifically include operational spills in their water budget. However, it could be included in their category for "distribution system losses" of 166,000 acre-ft/yr [1967-74] or in their category called "undefined loss" of 59,000 acre-ft/yr [1967-74] for outflow in the Carson Division.

A value of 50,000 acre-ft/yr is probably most representative for historical operational spills from the distribution system (fig. 4, table 2). This value is also subject to change under 1988 OCAP regulations.

Total loss from Lahontan Reservoir includes seepage and evaporation. The Bureau of Reclamation (1987a, p. 1-8) estimates that 400 acre-ft/yr is lost as seepage. Estimates of total reservoir loss are:

- 61,000 acre-ft/yr [1967-74] (Green and others, 1976, fig. 1); and

- 40,000 acre-ft/yr [1973-87] (Al Olson, Bureau of Reclamation, oral commun., 1993).

Estimates of evaporation are in the same range as estimates for total reservoir loss:

- 45,000 to 55,000 acre-ft/yr [time period not stated] (Barnes and Jorgenson, 1987, p. VIII5); and

- 44,500 acre-ft/yr [1987] (Bureau of Reclamation, 1987a, p. 1-8).
Thus, the amount of reservoir storage that is lost to seepage appears to be minor.

Some part of seepage from the reservoir is probably consumed by evapotranspiration from vegetation surrounding the reservoir. However, annual averages of inflow, outflow, and evaporation rates used to estimate potential seepage losses from the reservoir could be misleading because evaporation and evapotranspiration rates are low during winter months, while seepage from the reservoir continues. Detailed monthly analysis of reservoir volumes and surface area, evaporation rates, inflow and outflow rates, and consumptive use by phreatophytes surrounding the reservoir would allow a refined estimate for seepage loss from the reservoir.

Seepage is a major component of loss from the surface-water distribution system. Estimates of flow lost to seepage from canals and reservoirs are:

- 52,000 acre-ft/yr [1987] (Bureau of Reclamation, 1987a, p. 1-8);

- 70,000 acre-ft/yr [1992] (Bureau of

Reclamation, written commun., 1993; includes only V-Line, T-Line, S-Line, L-Line, and ALine Canals); and

- 105,000 acre-ft/yr [1930-70], (Clyde-CriddleWoodward, 1971, p. 6).

For the entire Newlands Project:

- 57,000 acre-ft/yr [1987] (U.S. Department of the Interior, 1988, p. 5); and

- 120,000 acre-ft/yr [1967-72] (CH2M Hill, 1973, fig. 1).

Clyde-Criddle-Woodward (1971, p. 62) applied published seepage rates for soil types and the measured wetted perimeters of canals and laterals at 50 sites to obtain their estimate for total seepage loss. CH2M Hill (1973) used actual measurements of seepage rates for different soil types within the Project. The BOR used seepage rates measured during ponding tests to allow a preliminary estimate of seepage only from the main canals used during the entire irrigation season; thus, 70,000 acre-ft/yr probably is a minimum seepage value.

Other studies include seepage under more generic categories such as "distribution system losses" or "system and lateral loss" and might include evaporation and operational spill:

- 143,000 acre-ft/yr [1985] (MacDiarmid, 1988, p. 52); and

- 166,000 acre-ft/yr [1967-74] (Green and others, 1976, fig. 2).

From the entire Newlands Project:

- 22,000 acre-ft/yr [1970-73] (Mahannah and others, 1975, p. 26). 
Green and others (1976, p. 13) imply that, because seepage is controlled by wetted perimeter and stage, seepage loss is relatively constant regardless of flow rate through the canal system. The amount of seepage is also dependent on the length of time that flow is present in canals and laterals. Also, ponding tests show that, on initial wetting of canals, seepage rates are significantly higher (Bureau of Reclamation, written commun., 1993). Thus, the total amount lost to seepage from the distribution system is a complex function of the seepage rate beneath the canals, the length of time that canals and laterals are used, and number of times that a canal or lateral is wetted during the irrigation season. Detailed studies of seepage losses from the distribution system are needed to refine estimates of this loss.

A value of 100,000 acre- $\mathrm{ft} / \mathrm{yr}$ is assumed to be representative of the historical seepage loss through the distribution system (fig. 4, table 2).

Estimates of streamflow lost to evaporation in the distribution system from regulating reservoirs, canals, laterals, and drains are:

- 20,000 acre-ft/yr [1930-70] (Clyde-CriddleWoodward, 1971, p. 6);

- 20,800 acre-ft/yr [1987] (Bureau of Reclamation, 1987a, p. 1-8); and

- 24,700 acre-ft/yr [1985] (MacDiarmid, 1988, p. 52).

From the entire Newlands Project:

- 21,000 acre-ft/yr [1987] (U.S. Department of the Interior, 1988, p. 5); and

- 25,000 acre-ft/yr [1967-72] (CH2M Hill, 1973, fig. 1).

A value of 20,000 acre-ft/yr is assumed to be representative of historical evaporation losses from canals and reservoirs within the distribution system (fig. 4, table 2).

Estimates of the total conveyance losses reported from irrigation releases between Lahontan Reservoir and farm headgates are:

- 143,300 acre-ft/yr [1985] (MacDiarmid, 1988, p. 52);

- 166,000 acre-ft/yr [1967-74] (Green and others, 1976, fig. 1); and

- 175,000 acre-ft/yr [1930-70] (Clyde-CriddleWoodward, 1971, p. 6).

This range of values compares well with the total of representative estimates of operational spill, seepage loss, and evaporation-170,000 acre-ft/yr (fig. 4, table 2).

An important "known" value is the reported delivery to farm headgates in the Carson Division, from which estimates of streamflow loss between
Lahontan Reservoir and farm headgates are calculated by difference. This value is also important because, along with total Project diversion from Lahontan Reservoir, it is used to calculate the Project efficiency set by OCAP (Bureau of Reclamation, 1987a, p. 1-6). The delivery to farm headgates is measured by TCID, and reported values are averaged over different time periods. Reported values are:

- 170,000 acre-ft/yr [1975-92] table 1, this report;

- 173,500 acre-ft/yr [1972-91] (Pahl, 1992, table 1);

- 189,200 acre-ft/yr [1985], (MacDiarmid, 1988, p. 52);

- 193,000 acre-ft/yr [1967-74] (Green and others, 1976, fig. 1); and

- 195,000 acre-ft/yr [1930-70] (Clyde-CriddleWoodward, 1971, p. 6).

For the entire Newlands Project:

- 186,500 acre-ft/yr [1981-91] (Bureau of Reclamation, 1992b, p. 15);

- 204,100 acre-ft/yr [1963-85] (Bureau of Reclamation, 1986, p. IV-49); and

- 211,000 acre-ft/yr [1967-72] (CH2M Hill, 1973, fig. 1).

Estimates of headgate delivery to the Truckee Division range from about 20,000 acre-ft/yr [1987] (Bureau of Reclamation, 1987a, p. 1-8) to 30,000 acre-ft/yr [1967-74] (Green and others, 1976, table 3). Thus, the more recent estimates of flow to the entire Newlands Project by the Bureau of Reclamation (1992b and 1986) listed above could be reduced to a range from about 160,000 to $180,000 \mathrm{acre}-\mathrm{ft} / \mathrm{yr}$ for the Carson Division.

A value of 170,000 acre-ft/yr is estimated to be representative of historical headgate delivery (fig. 4 , table 2). This value compares well with the difference between representative values for net irrigation diversions of 340,000 acre-ft/yr and conveyance losses of 170,000 acre- $\mathrm{ft} / \mathrm{yr}$. Because the estimates for operational spill from the distribution system and for seepage losses are based upon calculated differences and few actual measurements, their representative values could be in error. However, the total for operational spill, seepage, and evaporation should equal the difference between irrigation diversions and headgate delivery $-170,000$ acre-ft/yr.

The maximum allowable water delivery to irrigable lands with water rights is set by the Alpine Decree (Bureau of Reclamation, 1992a, p. 15). The Alpine Decree allows annual diversions of 4.5 acre$\mathrm{ft} / \mathrm{acre}$ for bench lands and 3.5 acre-ft/acre for bottom lands, although the exact amount applied by individual irrigators may be somewhat different. Bench and 
bottom lands have been designated by Bureau of Reclamation (1992a), based on soil characteristics determined by Dollarhide (1975). The historical designation of bench and bottom lands is subject to change, pending a decision by the Nevada Federal District Court. Under the proposed designation, bench lands are generally west of Fallon, near Soda Lake (sometimes referred to as Big Soda Lake), and the Swingle Bench. Bottom lands cover almost all remaining irrigated land of the Carson Division.

The Bureau of Reclamation (1987a, p. 1-5) used estimates of 4,270 acres of bench land and 49,890 acres of bottom land to obtain a headgate requirement of 193,840 acre-ft/yr in the Carson Division of the Project in 1987. Bench land totaling 3,400 acres and bottom land totaling 53,200 acres were delineated in the Carson Division using remote sensing to determine lands irrigated one or more years from 1984 to 1990 (Bureau of Reclamation, 1992c). Applying the Alpine Decree allocations, a total of 201,500 acre$\mathrm{ft} / \mathrm{yr}$ headgate requirement results. These values are somewhat greater than the representative estimate for historic headgate delivery. From field measurements, Guitjens and Mahannah (1973) and the Bureau of Reclamation (1971) documented that, in the 1970's, actual field applications differed from the bench/bottom-land diversion rates and varied considerably with location.

In addition to surface water delivered to headgates, precipitation on irrigated land is a source of water available for consumptive use by crops. Because studies have shown that consumptive use takes place during the non-irrigation season and annually averages more than 1 acre-ft/acre (Guitjens and Mahannah, 1976, p. 3), the total annual precipitation is used to estimate precipitation available for consumptive use. Estimates of the volume of precipitation available for consumptive use on irrigated lands are:

- 18,000 acre-ft/yr [1985] (MacDiarmid, 1988, p. 54); and

- 23,400 acre-ft/yr [1930-70] (Clyde-CriddleWoodward, 1971, p. D-8).

For the entire Newlands Project:

- 19,000 acre-ft/yr [1970-73] (Mahannah and others, 1975 , p. 26); and

- 27,000 acre-ft/yr [1967-72] (CH2M Hill, 1973, fig. 1).

A value of 20,000 acre-ft/yr is assumed to be the most representative for the volume of precipitation available for consumptive use on irrigated lands (fig. 4, table 2). Annual precipitation combined with the representative value for headgate deliveries, totals 190,000 acre- $\mathrm{ft} / \mathrm{yr}$, which is available for on-farm consumptive use.

Part of the water applied to fields runs off as return flow to the distribution or drainage systems. The amount lost as runoff from three irrigated plots was measured by CH2M Hill (1973, p. 4-16 to 18) to vary from 42 to 48 percent of farm delivery. Similar measurements reported by Guitjens and Mahannah (1976, p. 11) at eight sites in the Carson Division showed from 0 to 20 percent runoff. The Bureau of Reclamation (1971, p. 9-19) measured runoff from six farms in the Carson Division that varies from 0 to 33 percent. In all of these studies, runoff from bench land was minimal, and bottom land had the largest percentage. Also, part of the water applied to fields replenishes soil-moisture storage and percolates to the water table to be consumed by crops or, over time, discharges to drains. No estimates of the proportion of applied water that eventually discharges to drains have been reported. Farm efficiency has been used to account for total on-farm loss, which is not often measured.

Farm efficiency is defined as the ratio between crop consumptive use and headgate delivery. Sometimes an additional volume of water required to leach accumulated salts from the soil profile is included in the on-farm loss estimate. Mahannah and others (1975, p. 27) use a value of 15 percent of consumptive use, or 0.6 acre-ft/acre of applied water per year to leach salts. Farm efficiencies used to estimate onfarm loss of delivered water range from 67 percent (MacDiarmid, 1988, p. 24; Lyford and Townsend, 1985 , p. 23) to 75 percent (Mahannah and others, 1975, p. 27; Green and others, 1976, p. 11). Using the definition above, farm efficiencies are also reported to be as much as 230 percent at locations where crops derive water for consumptive use from the water table (Mahannah and others, 1975, p. 21).

The wide range in runoff and farm efficiencies discussed above shows that the total on-farm loss and components of on-farm loss of water vary greatly and are poorly known. More direct measurements of these components of the surface-water flow budget are needed to determine realistic estimates of on-farm loss and seepage to the water table beneath irrigated land.

Reported estimates of total on-farm loss of water are:

- 48,000 acre-ft/yr [1967-74] (Green and others, 1976, fig. 1);

- 62,500 acre-ft/yr [1985] (MacDiarmid, 1988, p. 54); and

-70,000 acre-ft/yr [1930-70] (Clyde-CriddleWoodward, 1971, p. 6). 
For the entire Newlands Project:

- 81,000 acre-ft/yr [1967-72] (CH2M Hill, 1973, fig. 1); and

- 131,000 acre-ft/yr [1970-73] (Mahannah and others, 1975 , p. 26).

A value of 60,000 acre-ft/yr is assumed to be representative of historical on-farm loss (fig. 4, table 2).

Subtracting on-farm loss from representative values for headgate delivery and precipitation on irrigated lands, about 130,000 acre-ft/yr is available for consumptive use (table 2). In addition to this amount, an unmeasured part of the surface-water losses - operational spill from the distribution system, seepage, and on-farm losses-totaling 240,000 acre$\mathrm{ft} / \mathrm{yr}$, recharges the shallow aquifer and is available for crop consumptive use.

Estimates of consumptive use of water by irrigated crops have a wide range depending on the assumed consumptive-use rate and the number of irrigated acres to which the rate is applied:

- 125,000 [1930-70] (Clyde-Criddle-Woodward, 1971 , p. 51);

- 162,000 [1967-74] (Green and others, 1976, fig. 2);

- 167,000 [1985] (MacDiarmid, 1988, p. 53); and

- 226,000 [1984-90] (reported area of irrigated lands times 4.0 acre-ft/acre).

For the entire Newlands Project:

- 245,000 [1967-72] (CH2M Hill, 1973, fig. 1); and

- 258,000 [1970-73] (Mahannah and others, 1975 , p. 26).

MacDiarmid (1988, p. 52) used a farm efficiency of 67 percent to obtain his estimate of crop consumptive use. Mahannah and others $(1975$, p. 24) and CH2M Hill (1973, p. 3-7) used an average annual consumptive-use rate of 4.0 acre-ft/acre for alfalfa managed for maximum crop production (Guitjens and Mahannah, 1976, p. 4). The estimates are based on several years of direct measurement using lysimeters at the University of Nevada, Reno, Newlands Field Laboratory (pl. 1). The Alpine Decree applies an average annual consumptive-use rate for alfalfa of 3.25 acre-ft/acre (Lyford and Townsend, 1985, p. 21). Green and others (1976) and Clyde-Criddle-Woodward (1971) also applied lower annual rates for consumptive use by alfalfa: 3.2 and 2.33 acre-ft/acre and applied lower rates for other types of crops on 57,000 and 56,000 irrigated acres, respectively.
Applying an annual consumptive-use rate of 4.0 acre$\mathrm{ft} /$ acre to the 56,600 irrigated acres [1984-90] reported by the Bureau of Reclamation (1992c) results in 226,000 acre- $\mathrm{ft} / \mathrm{yr}$ of crop consumptive use as reported in the previous paragraph.

Water is also consumed by non-crop vegetation and phreatophytes near irrigated lands of the Carson Division. The Bureau of Reclamation (1987a, p. 2-28) provides data allowing an estimate of 11,200 acre- $\mathrm{ft} / \mathrm{yr}$ lost to phreatophytes along the distribution system and assumes that phreatophytes cover 5 percent of irrigated acres and use 4.0 acreft/acre annually. CH2M Hill (1973, p. 4-4) estimates that losses to non-crop vegetation on irrigated lands below Lahontan Reservoir are 18,000 to 20,000 acreft/yr. Clyde-Criddle-Woodward (1971, p. 63 and D-8) estimate that almost 17,000 acre- $\mathrm{ft} / \mathrm{yr}$ is consumed by phreatophytes surrounding the regulating reservoirs in the distribution system, and that about 9,000 acre-ft/yr is lost to non-crop vegetation along canal and ditch areas over the entire Newlands Project.

The total loss of water between Lahontan Reservoir and points where outflow from irrigated land is measured has averaged about 200,000 acre$\mathrm{ft} / \mathrm{yr}$ [1975-92] (table 1, column 8). If, from 1975 to 1992 , the net change in ground-water storage was small, as reported by Seiler and Allander (1993), $200,000 \mathrm{acre}-\mathrm{ft} / \mathrm{yr}$ represents the net volume of water lost to evaporation and total consumptive use by vegetation upstream from the points where outflow is measured. If the representative value for evaporation from canals and reservoirs of 20,000 acre-ft/yr is correct and is relatively constant from year to year, the total consumptive use by both crops and non-crop vegetation above the points of outflow must be about 180,000 acre-ft/yr.

Applying a volume of 180,000 acre-ft/yr to 56,600 acres of land irrigated within the Carson Division from 1984 to 1990 (Bureau of Reclamation, 1992c), an annual consumptive-use rate of about 3.2 acre-ft/acre results. This value is less than the 4.0 acre-ft/acre obtained for alfalfa from lysimeter studies by Guitjens and Mahannah (1976, p. 4). Some reasons for this discrepancy could be that (1) gaged flows used to calculate the net loss of 200,000 acre-ft/yr are inaccurate, (2) maximum production is not usually achieved within the Carson Division, (3) consumptive use by crops other than alfalfa or non-crop vegetation reduces the average consumptive-use rate, or (4) overall crop production decreases in years having a limited supply of water. To resolve the discrepancy in crop-consumptive-use 
rate, continued and accurate measurements of crop consumptive use and surface-water flow rates are needed along with studies to refine the extent and consumptive-use rates of non-crop vegetation on irrigated lands. For purposes of this study, a value for total consumptive-use requirements on irrigated land of 180,000 acre- $\mathrm{ft} / \mathrm{yr}$ will be used as representative of historical conditions (fig. 4 , table 2).

The consumptive-use requirement of 180,000 acre-ft/yr results in a deficit of about 50,000 acre-ft/yr when compared with the total amount available for consumptive use from surface water and precipitation. This deficit could be supplied from upstream surfacewater losses that recharge the shallow aquifer.

Several investigators have recognized that some water consumed by crops is derived from the shallow aquifer. Two mechanisms are proposed by which ground water supplies subirrigation: (1) seepage lost through coarse-textured soils on bench-land areas is assumed to move downgradient and is available for subirrigation on bottom-land areas, and (2) overapplication of surface water early in the irrigation season increases ground-water storage which is available for consumptive use later in the season when there is an under-application of surface water (CH2M Hill, 1973, p. 3-12; Mahannah and others, 1975, p. 25; Green and others, 1976, p. 12; MacDiarmid, 1988, p. 54). Also, water lost to seepage from nearby canals and laterals could provide ground water for crop consumptive use on adjacent fields. Some combination of these mechanisms probably takes place, but one mechanism could be more dominant than the other depending upon location in the basin.

Estimates of the amount of water derived from the water table by crops vary considerably. Lyford and Townsend (1985, p. 23) use a value of 22 percent for the portion of crop consumptive use that is derived from ground water. Guitjens and Mahannah (1973, p. 6) report data showing that ground water supplies as much as 29 percent of the crop consumptive use in some areas. Mahannah and others (1975, p. 26) show that a large amount of water is supplied for crop use from seepage losses and subirrigation, but they do not estimate the amount. $\mathrm{CH} 2 \mathrm{M}$ Hill (1973, p. 4-12) used a value of 33 percent for crop consumptive use from ground water over the entire Newlands Project. Lyford and Townsend (1985, p. 25, 26) also cite several reports showing that consumptive use derived from a shallow water table can be greater than 90 percent of total use and that it can take place under saline ground-water conditions and from fluctuating water tables. Conversely, Marston (1989) reports that, at the Newlands Field Laboratory, ground water does not supply sufficient water to maintain crop production when surface-water sources are lacking. Thus, whether ground water contributes to crop consumptive use is uncertain.

The amount of water supplied to crops from the water table is reported to vary depending upon the depth to water. Using lysimeters in the Reno area, Tovey $(1963$, p. 8$)$ showed that consumptive use was 23 to 26 percent higher when depth to water was $2 \mathrm{ft}$ below land surface compared with sites with a watertable depth of $8 \mathrm{ft}$ and greater. Using measurements of inflow and outflow from two areas in the Carson Desert, CH2M Hill (1973, p. 4-12) show that where depth to water was 4 to $7 \mathrm{ft}$ below land surface, 23 percent of the water used by crops was derived from ground water. Where depth to water was 1 to $4 \mathrm{ft}$ below land surface, the value increased to 46 percent. The Bureau of Reclamation (1986, p. 32) assumes that 22 percent of consumptive use is derived from the water table in areas designated as bottom land, and that the water table does not supply consumptive use on bench lands. Seiler and Allander (1993, fig. 4) report that the depth to water ranges from 5 to $10 \mathrm{ft}$ below land surface beneath most irrigated land in the Carson Division.

Estimates of consumptive use derived from ground water on irrigated lands range widely:

- 17,000 acre-ft/yr [1967-74] (Green and others, 1976, p. 9);

- 27,800 acre-ft/yr [1985] (MacDiarmid, 1988, p. 54 );

- 53,200 acre-ft/yr [1987] (Bureau of Reclamation, 1987a, p. 2-27); and

- 86,600 acre-ft/yr [1967-72] (CH2M Hill, 1973, adjusted from value for entire Newlands

Project using data from CH2M Hill, 1973, table 1 and p. 3-10).

For the entire Newlands Project:

- 88,000 acre-ft/yr [1967-72] (CH2M Hill, 1973, p. 3-12).

The discussion above shows that the ground-water contribution to, and mechanisms that supply ground water for consumptive use on, irrigated lands are not well known. In table 2, the volume of ground water required to meet consumptive use would change if onfarm loss is actually different from $60,000 \mathrm{acre}-\mathrm{ft} / \mathrm{yr}$, or if the total consumptive-use requirement is actually different from 180,000 acre-ft/yr. The estimate for on-farm loss is based on few measurements, and a small change in the consumptive-use rate results in a large change in the consumptive-use requirement. Further study of on-farm losses and the proportion of surface-water and ground-water use by crops is required to refine the surface-water budget. 
Using the representative estimates for historical surface-water flows shown in table 2, 50,000 acre$\mathrm{ft} / \mathrm{yr}$ is required from the shallow aquifer to supply the deficit in consumptive use (fig. 4, table 2).

If 50,000 acre-ft/yr of shallow ground water, derived from surface-water losses from the distribution system, is used by crops then 50,000 acre- $\mathrm{ft} / \mathrm{yr}$ can be subtracted from the 240,000 acre-ft/yr available from surface-water losses. This leaves 190,000 acre-ft/yr available for outflow from irrigated lands to wetland areas and the Carson Sink (fig. 4, table 2).

Surface water enters the wetland areas through many drains, making measurement of total outflow difficult. Measurements of inflow to the Stillwater WMA at major drains is available from the late 1960's (Green and others, 1976, table 4). In contrast, measurements of inflow to Carson Lake at major drains have been made since only the early 1980's (Bureau of Reclamation, 1987a, p. 2-24).

Reported inflows to wetland areas vary because, as stated above, until recent years estimates of inflows were based on gaged records for only part of the drain flow entering the wetlands. In some reports, estimates include a correction factor for ungaged flow and other reports do not state whether a correction factor was used. Also, within both the Stillwater WMA and Carson Lake wetlands, water is used to irrigate pasture, and some reports do not state whether this flow is included in wetland inflow. In this report, total outflow includes flow to wetland areas in Carson Lake, Stillwater WMA, Carson Sink, and irrigated pasture in the Carson Lake area, but does not include flow to irrigated land in the Stillwater WMA.

Estimates of flow to Carson Lake and Stillwater WMA from Carson Division lands are:

- 95,500 acre-ft/yr [1987] (Bureau of Reclamation, 1987a, p. 2-27);

- 99,600 acre-ft/yr [1972-91] (Pahl, 1992, table 1);

- 120,000 acre-ft/yr [1975-92] table 1, this repat, and

- 149,000 acre-ft/yr [1967-74] (Green and others, 1976, fig. 1).

About 120,000 acre-ft/yr is assumed to be the best estimate of flow to the Stillwater WMA and Carson Lake areas.

Estimates of flow to the Carson Sink are based upon flow of the Carson River gaged by USGS. This gage has been operated at two different sites. From 1967 to 1985, the site was downstream from irrigated lands (USGS gaging station, Carson River below Fallon, pl. 1). Since 1985, the site has been operated upstream from some irrigated lands and may not include return flow from these lands (USGS gaging station, Carson River at Tarzan Road, pl. 1).
Flows of the Carson River below Fallon reported over different time periods are:

- 22,200 acre-ft/yr [1985-91, water years]

(Garcia and others, 1992, p. 167);

- 39,000 acre-ft/yr [1967-74] (Green and others, 1976, fig. 1);

- 50,000 acre-ft/yr [1975-92] table 1, this report; and

- 54,600 acre-ft/yr [1967-85, water years] (Frisbie and others, 1985, p. 137).

About 50,000 acre- $\mathrm{ft} / \mathrm{yr}$ is assumed to be the best estimate of flow to the Carson Sink from the Carson River.

Reported estimates of total outflow from the Carson Division range from:

- 146,200 acre-ft/yr [1929-46] (Bureau of Reclamation, [1951?], p. 10);

- 170,000 acre-ft/yr [1975-92], table 1, this report;

- 173,300 acre-ft/yr [1985] (MacDiarmid, 1988, p. 54);

- 185,000 acre-ft/yr [1930-70] (Clyde-CriddleWoodward, 1971, p. 6); and

- 188,000 acre-ft/yr [1967-74] (Green and others, 1976, fig. 1).

From the entire Newlands Project:

- 181,000 acre-ft/yr [1970-73] (Mahannah and others, 1975 , p. 26); and

- 202,000 acre-ft/yr [1967-72] (CH2M Hill, 1973, fig. 1).

About 170,000 acre- $\mathrm{ft} / \mathrm{yr}$ is assumed to be representative of the historical outflow from the Carson Division (table 1, table 2).

This value is slightly less than the representative estimate of water available for outflow, 190,000 acre-ft/yr (fig. 4, table 2), assuming that the representative estimates for operational spills, seepage losses, on-farm losses, and consumptive use from ground water are correct. Ungaged outflow not accounted for in table 1 or inaccuracies in the representative estimates could explain this difference.

Surface-water outflow from irrigated lands is consumed by evaporation and evapotranspiration at wetlands or near the Carson Sink. During normal years most outflow is directed to wetland areas to maintain wildlife habitat. Reported estimates for consumptive use at wetland areas near Carson Lake and Stillwater WMA provide a check on the estimate of outflow from irrigated lands.

Clyde-Criddle-Woodward (1971, p. D-8) estimates $21,000 \mathrm{acre}-\mathrm{ft} / \mathrm{yr}$ of precipitation at wetland areas near Carson Lake, Stillwater WMA, and the Carson Sink. This results in a total of about 190,000 acre-ft/yr (table 2) to 210,000 acre-ft/yr (fig. 4) available for consumptive use near the wetlands. 
Clyde-Criddle-Woodward (1971, p. D-8) estimate that consumptive use by non-crop vegetation at the wetlands is about 155,000 acre-ft/yr. Their consumptive-use rates for the vegetation at wetland areas near Carson Lake, Stillwater WMA, and the Carson Sink ranged from about 2.8 to $4.8 \mathrm{ft} / \mathrm{yr}$ for cattails, tules, sedges, and saltgrass of varying plant densities. These rates were applied to about 51,000 acres of vegetation near wetland areas. However, maps showing the location of the 51,000 acres are not available. In addition, Clyde-Criddle-Woodward (1971, p. D-8) estimate about 58,000 acre-ft/yr for evaporation from about 15,000 acres of open-water bodies in the same areas. The total loss resulting from evapotranspiration and evaporation in wetland areas and the Carson Sink is about 213,000 acre-ft/yr. Green and others (1976, p. 5) estimate that $149,000 \mathrm{acre}-\mathrm{ft} / \mathrm{yr}$ is lost to evaporation from wetland areas near the Carson Lake and Stillwater WMA based on an evaporation rate of $4.5 \mathrm{ft} / \mathrm{yr}$ for about 33,000 wetland acres. However, they did not include estimates for consumptive use of water by vegetation near wetland areas.

Estimates of the current amount of open-water area at Stillwater WMA, Carson Lake, and Indian Lake wetlands total about 29,000 acres at full capacity (Gary Shellhorn, U.S. Fish and Wildlife Service, written commun., 1993). During the 1970's, wetlands at Carson Lake covered from 4,000 to 5,000 additional acres (Norman A. Saake, U.S. Fish and Wildlife Service, written commun., 1993). Using an evaporation rate of $5 \mathrm{ft} / \mathrm{yr}$, from 165,000 to $170,000 \mathrm{acre}-\mathrm{ft} / \mathrm{yr}$ was consumed from the mid-1970's to 1992 with wetlands at full capacity. Lico $(1992$, p. 8) states that most open-water bodies in Stillwater WMA recharge the shallow aquifer. In addition to evaporation losses, an unknown volume of surface water recharges the shallow aquifer and is consumed by phreatophytes surrounding wetland areas. Thus, discharge by both evaporation and evapotranspiration near wetland areas could total more than 210,000 acre- $\mathrm{ft} / \mathrm{yr}$ (fig. 4, table 2).

The discussion above summarizes available estimates of flow rates describing the historical distribution of surface water, and rates for processes that control the distribution of surface water in the Carson Division. Uncertainties in many of the values do not allow complete accounting of surface water released from Lahontan Reservoir.

Values of several water-budget components are uncertain: operational spills and seepage loss from the distribution system, on-farm loss, consumptive use of ground water by irrigated crops, and non-crop consumptive use on irrigated lands and wetland areas. Refinement of these values would provide a better approximation of the distribution of water in the Carson Division and allow closer estimation of the effects of changes in water use.

\section{Annual Variations in Surface-Water Flow}

Analysis of the annual variations in flow rates through the system listed in table 1 can provide further insight into processes that are important in controlling the distribution of surface water. The values presented in table 1 represent the best available estimates for the distribution of surface-water flow under the conditions present from 1975 to 1992 in the Carson Division. Although values for outflow are estimated or derived from gaging station records with uncertain accuracy, they can be used (1) to determine approximate relations between flow at different points in the surface-water system, (2) to gain greater understanding of how the system works, and (3) to determine data that are needed to refine that understanding. Given the uncertain accuracy of some of the values in table 1 , the annual relations discussed below should not be considered exact, but do show general trends.

Regression equations shown in figures 5-7 were developed using the principle of least squares and, except for figure 7 , data from years when releases from Lahontan Reservoir were less than 350,000 acre$\mathrm{ft} / \mathrm{yr} ; \mathrm{R}^{2}$ is a measure of the variability accounted for by the regression equation, with a perfect relation having an $R^{2}$ equal to 1 . The reliability of the regression equation can be evaluated by comparing the difference, or residual, between values calculated using the equation and observed values (Iman and Conover, 1983, p. 366-372). Comparisons for the equations in figures 5-7 show an even scatter of points above and below zero residual, implying that assumptions of the least-squares method have not been violated.

Figure 5 shows the relation between total releases from Lahontan Reservoir and headgate deliveries. For releases less than about 350,000 acre-ft/yr, headgate delivery has ranged from about 60,000 acre$\mathrm{ft} / \mathrm{yr}$ in dry years to about $200,000 \mathrm{acre}-\mathrm{ft} / \mathrm{yr}$ in normal and wet years, and is slightly more than half of the total volume released. For releases greater than 350,000 acre- $\mathrm{ft} / \mathrm{yr}$, headgate delivery is generally about 200,000 acre-ft/yr or less. For years with releases from Lahontan Reservoir greater than 350,000 acre-ft/yr, a large part of the losses above farm headgates flows directly to wetlands and the Carson Sink during winter and early spring. Less water was delivered in the wet years of 1982 and 1983 when winter and spring precipitation decreased the demand for surface-water irrigation. 


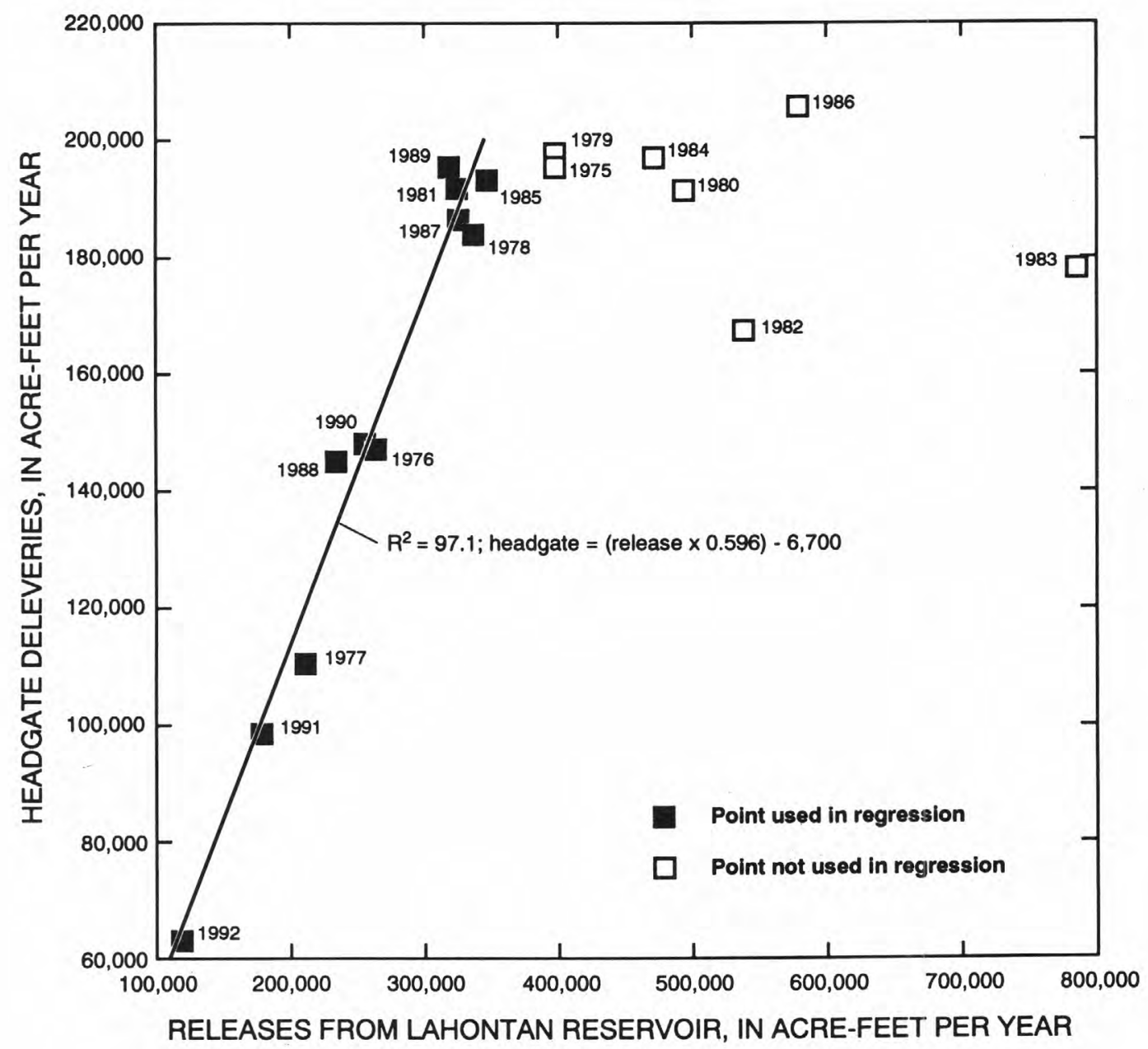

Figure 5. Headgate deliveries as function of releases from Lahontan Reservoir; $R^{2}$ is measure of variability accounted for by regression equation.

Figure 6 shows (1) the loss from the distribution system between Lahontan Reservoir and the farm headgates and (2) the total outflow, as a function of the volume released from Lahontan Reservoir. The volumes of loss upstream from farm headgates and total outflow increase at similar rates with increasing amounts of water released from Lahontan Reservoir. For releases greater than 350,000 acre-ft/yr, losses above farm headgates and total outflow increase at a rate about equal to the increase in releases.

As shown in table 1 (column 8), more than 300,000 acre-ft/yr was lost from the surface-water distribution system in 1986-a considerable increase over other years. In 1986, annual precipitation was low in the Fallon area; 2.55 in. was received at the University of Nevada, Reno, Newlands Field Laboratory (National Oceanic and Atmospheric Association, 1986, p. 3). However, runoff from the
Carson and Truckee Rivers was high because of above-normal precipitation in the Sierra Nevada. Although the precautionary release in 1986 was routed through the entire distribution system, the large amount of loss implies that soil-moisture conditions prior to the irrigation season have some control on the volume of seepage losses.

For annual releases less than 350,000 acre- $\mathrm{ft} / \mathrm{yr}$ from Lahontan Reservoir, losses upstream of farm headgates and total outflow are each about 40 percent of the volume of released water (fig. 6). The relation between total outflow and releases shown in figure 6 implies that releases greater than about 70,000 acre$\mathrm{ft} / \mathrm{yr}$ are required before outflow takes place from irrigated lands (release of 70,000 acre-ft/yr, times 0.44 , minus 30,000 equals approximately zero; see equation, fig. 6). As noted by Glancy (1986, p. 39), water levels in the shallow aquifer near irrigated lands 


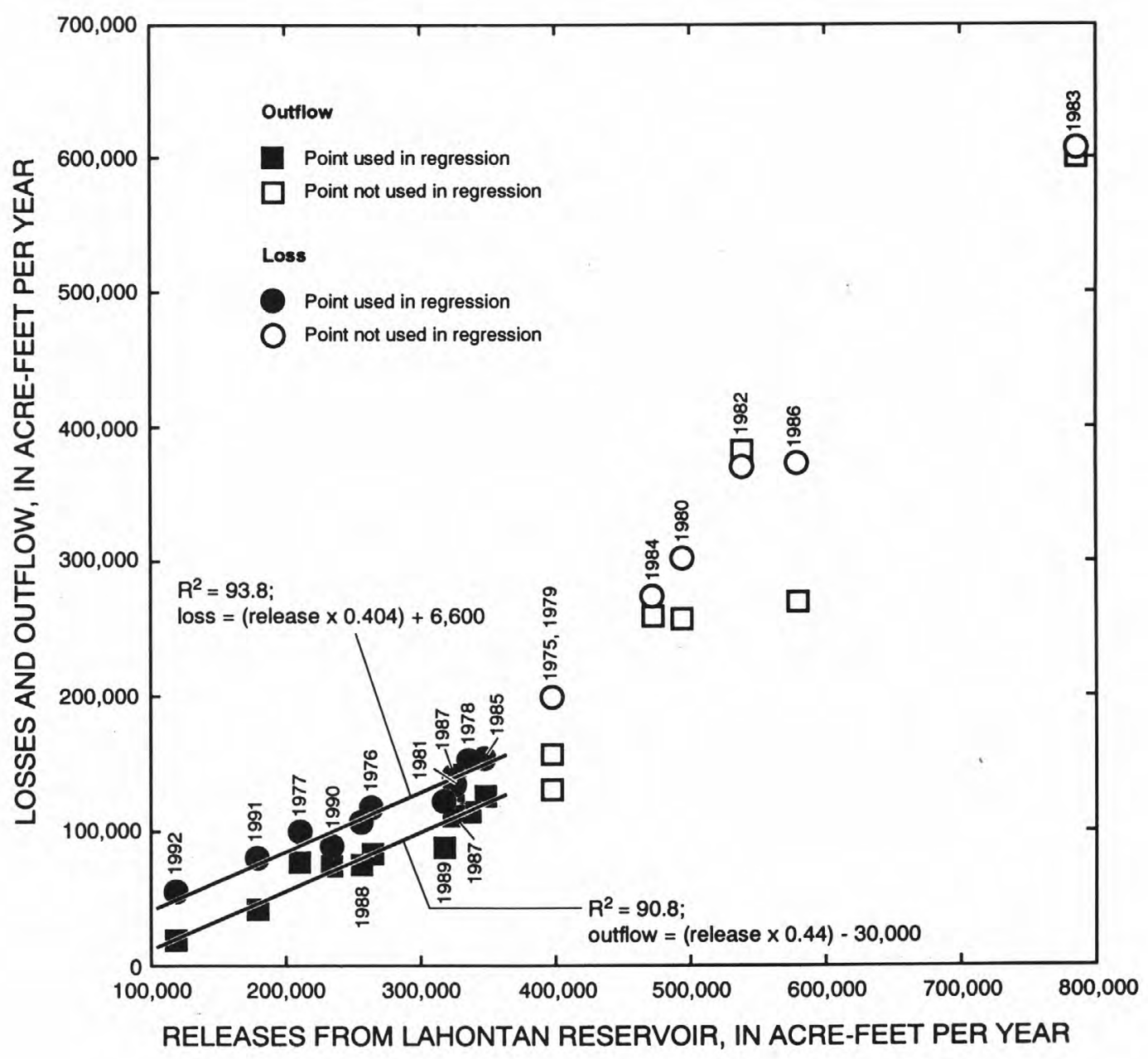

Figure 6. Loss above farm headgates and outflow from irrigated lands as function of releases from Lahontan Reservoir; $\mathrm{R}^{2}$ is measure of variability accounted for by regression equation.

rise at the start of the irrigation season. The value of 70,000 acre-ft/yr could represent the amount of seepage required to saturate the distribution system, and thus, represent the potential recharge to the shallow aquifer at the start of the irrigation season. Figure 6 also shows that total outflow is generally less than losses from the distribution system. Average values for these two volumes in table 1 differ by about 30,000 acre-ft/yr.

A linear relation exists between the losses upstream from farm headgates and total outflow (fig. 7). For releases from Lahontan Reservoir greater than 350,000 acre- $\mathrm{ft} / \mathrm{yr}$, the general one-to-one relation is expected. For flows less than 350,000 acre$\mathrm{ft} / \mathrm{yr}$, the relation in figure 7 implies either that a large part of the total outflow is operational spill from the distribution system or that there is a hydrologic connection that supplies water lost to seepage up- stream from farm headgates to drains where outflow is measured. Detailed flow measurements within the distribution system could determine whether outflow consists of operational spill or water that has moved quickly through the shallow aquifer.

Because the outflow consists of a mixture of water lost above farm headgates and on-farm losses, the volume of water lost to seepage and consumptive use from the distribution system is difficult to determine relative to the volume lost to seepage and consumptive use from irrigated fields. More accurate estimation of on-farm use of delivered water and net losses is not possible without measurements showing the proportion of operational spill and on-farm losses that make up total outflow.

For years in which less than 350,000 acre-ft/yr are released from Lahontan Reservoir, most of the releases are made during the irrigation season. Analysis of 


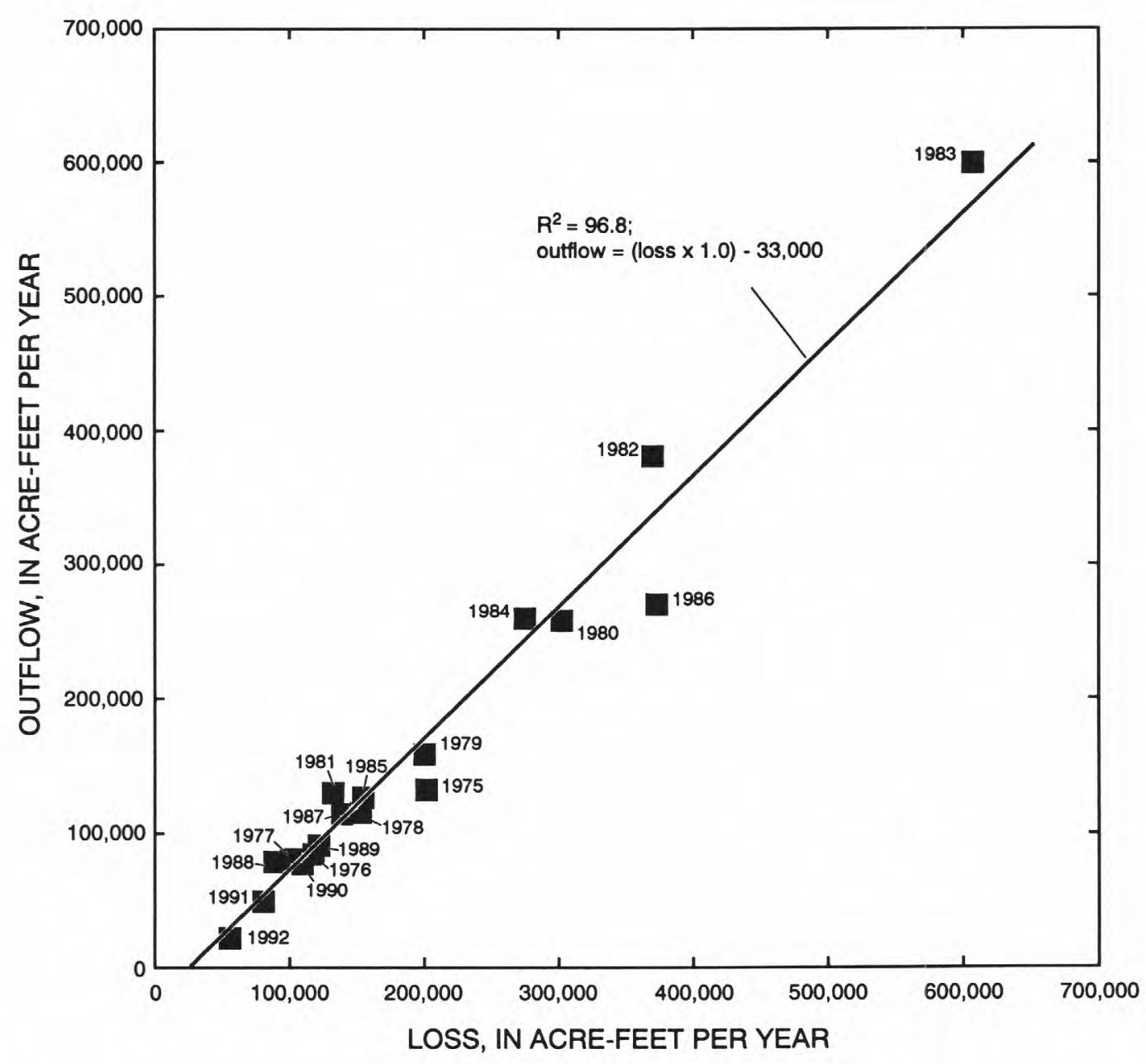

Figure 7. Outflow from irrigated lands as function of loss above farm headgates; $R^{2}$ is measure of variability accounted for by regression equation. All points were used in regression.

\section{GROUND WATER Occurrence of Ground Water}

flow volumes through the distribution system during these years could provide further insight into how water moves through the distribution system and into processes that control the movement of water between the surface-water and ground-water systems near irrigated land.

Analyses of flow volumes at monthly, or shorter, time intervals would permit a more accurate determination of the relations between flow at various positions in the surface-water distribution system. This detailed analysis is beyond the scope of this investigation.
The major ground-water resources in the Carson Desert are found in unconsolidated sediments and volcanic rocks beneath the floor of the valley. Rocks of Mesozoic age that make up the bulk of the Stillwater, West Humboldt, and Sand Springs Ranges probably store and transmit water in fracture systems as shown by geothermal studies, but the total volume is probably small. In this study, these rocks are assumed to form a boundary to most interbasin flow along the east and north sides of the basin, and a lower boundary to most ground-water flow beneath the entire Carson Desert. Mesozoic rocks are also present along the northwest edge of the basin, beneath the Hot Springs Mountains, at depths from 600 to 
4,500 ft below land surface (Benoit and others, 1982, figs. 11, 25). Mesozoic rocks probably are present at depths greater than $2,000 \mathrm{ft}$ beneath the Desert, White Throne, Blow Sand, Cocoon, and Bunejug Mountains (Willden and Speed, 1974; Morrison, 1964, p. 9-15). Tertiary volcanic rocks capping these mountain blocks could be permeable to ground-water flow. However, water-level data are lacking along topographic divides to determine if interbasin flow might be taking place. Saturated sediments and volcanic rocks beneath alluvial fans and the valley floor store and transmit large volumes of ground water and are the most important aquifers in the Carson Desert.

The depth to water beneath alluvial fans surrounding the valley ranges from more than $400 \mathrm{ft}$ below land surface near the mountain blocks to tens of feet below land surface near the toe of the alluvial fans, as indicated in drillers' logs. The depth to water beneath most of the valley floor is generally less than $25 \mathrm{ft}$ below land surface and, near irrigated areas, generally less than $10 \mathrm{ft}$ below land surface. Ground water is confined throughout much of the Carson Desert. Wells that penetrate to significant depths below the water table have water levels that are higher than the water table or the top of the formation that they tap, and commonly flow (Olmsted and others, 1984, p. 27; Morgan, 1982, p. 26; Glancy and Katzer, 1975, p. 16).

Surface-water irrigation in the Newlands Project area has changed the depth to water over large areas of the valley floor since the turn of the century. In 1904, Stabler (1904) installed more than 300 shallow wells and borings to measure depth to water and determine water quality (fig. $8 A$ ). Seiler and Allander (1993, fig. 4) compared the pre-irrigation water levels of Stabler (1904) with water levels measured in 1992 (fig. 8B). In 1904, the depth to water increased with distance from the natural channels of the Carson River. Depth to water was less than $10 \mathrm{ft}$ below land surface within 1 to $2 \mathrm{mi}$ of the channels and generally increased to at least $25 \mathrm{ft}$ in areas more than $2 \mathrm{mi}$ from the channels north of Fallon and ranged from 10-25 ft more than $2 \mathrm{mi}$ from the channels south of Fallon. In 1992, the water table had risen more than $15 \mathrm{ft}$ over large areas northeast of Fallon and, near Soda Lake, 25 to $40 \mathrm{ft}$ (Seiler and Allander, 1993, p. 11). Also, few areas had water levels less than 5 $\mathrm{ft}$ below land surface in 1992. The distribution of surface water over irrigated areas of the valley floor has decreased the depth to water in large areas, and installation of drains has increased the depth to water near old channels of the Carson River. Both processes made the depth to water more uniform, ranging from 5 to $10 \mathrm{ft}$ below land surface over much of the valley floor.
Depth-to-water information is also available from thousands of shallow holes drilled from 1955 to 1968 by the U.S. Soil Conservation Service to produce soils maps of irrigated land in the Carson Desert. Dollarhide (1975) gives a range for the depth to seasonal high water table for more than 100 soil types in the Carson Desert. The Bureau of Reclamation (1992a, p. 8) has summarized these data to produce the bench- and bottom-land designations for water allocation. Figure 9 shows the distribution of soils with a seasonal high water table more than $5 \mathrm{ft}$ and less than $5 \mathrm{ft}$ below land surface. Generally, the depth to seasonal high water table is more than $5 \mathrm{ft}$ below land surface in areas that have not been irrigated (fig. 1). Exceptions are the Swingle Bench area and small sections of irrigated land around Soda Lake. The V-Line, T-Line, N-Line, and D-Line Canals all cross soils with a seasonal high water table deeper than $5 \mathrm{ft}$. These canals have a high potential for flow loss to seepage and for recharge to the shallow aquifer.

\section{Description of Aquifers}

An aquifer is defined as "a formation or part of a formation that contains sufficient saturated permeable material to yield significant quantities of water to wells and springs" (Lohman and others, 1972, p. 2). In general usage, the term aquifer often implies a discrete hydrogeologic unit. In the Carson Desert, boundaries between aquifers are indistinct, and stresses imposed on one aquifer can be transmitted to the other aquifers. In this report, the term aquifer is used to describe a hydrogeologic unit that has lithologic or water-quality characteristics that allow it to be distinguished from other hydrogeologic units.

The most comprehensive description of aquifers in the study area is given by Glancy (1986), who delineated three alluvial aquifers and a basalt aquifer in the Fallon area of the Carson Desert. The alluvial aquifers described by Glancy (1986) consist of (1) a shallow aquifer present from the water table to $50 \mathrm{ft}$ below land surface, (2) an intermediate aquifer extending from $50 \mathrm{ft}$ to between 500 and $1,000 \mathrm{ft}$ below land surface, (3) a deep aquifer extending from 500 to $1,000 \mathrm{ft}$ below land surface to between 3,000 and $8,000 \mathrm{ft}$ below land surface. He does not correlate all of these aquifers with geologic units. Howev$\mathrm{er}$, the shallow aquifer probably extends to the bottom of the Sehoo Formation and the intermediate aquifer correlates with the Wyemaha, Eetza, and Paiute Formations. 
Glancy's (1986) alluvial aquifers were defined for irrigated areas near Fallon and immediately downgradient. The same definitions may not apply in areas of the Carson Desert distant from irrigation.

The term "alluvial" implies aquifer materials that were deposited by moving water. Because much of the aquifer material in the Carson Desert was deposited in a lake environment, the term alluvial is not applied to the shallow, intermediate, and deep aquifers in this report.

The basalt aquifer is a mushroom-shaped body of basalt near Fallon (fig. 12) that is exposed at Rattlesnake Hill but generally is from 200 to $600 \mathrm{ft}$ below land surface and extends to more than $1,000 \mathrm{ft}$ below land surface (Glancy, 1986, p. 6).

Several reports suggest that at some locations, a near-surface zone could exist in the uppermost part of the shallow aquifer of Glancy (1986). Previous to the Glancy (1986) report, Clyde-Criddle-Woodward (1974) divided ground water in the Newlands Project into three zones: zone 1 extends from the top of saturated sediments downward to a clay layer in the Sehoo Formation; zone 2 is beneath the Sehoo clay and consists of stratified units including many other clay layers; and zone 3 is the basalt described by Glancy (1986). These zones are analogous to Glancy's (1986) shallow, intermediate, and basalt aquifers, except that zone 1 covers only the uppermost part of Glancy's (1986) shallow aquifer.

The Bureau of Reclamation (1987b, p. 21) reports that a shallow water table 3 to $5 \mathrm{ft}$ below land surface forms above clay of the Sehoo Formation during the peak of the irrigation season, dropping to between 6 to $12 \mathrm{ft}$ in depth after the irrigation season. Clay of the Sehoo Formation is breached to depths greater than $30 \mathrm{ft}$ where old channels of the Carson River now filled with sand have eroded through it, allowing downward flow (Marty Townsend, U.S. Soil Conservation Service, oral commun., 1993).

About $10 \mathrm{mi}$ south of Fallon, an impermeable clay unit of the Sehoo Formation greater than $30 \mathrm{ft}$ thick is found at depths of 20 to $25 \mathrm{ft}$ below land surface (Lico and others, 1987, p. 97). The clay impedes downward ground-water flow. They describe shallow, intermediate, deep, and evapotranspiration zones in the shallow aquifer, at this site. $\mathrm{CH} 2 \mathrm{M}$ Hill (1989, p. 4-1) also report a clay barrier controlling shallow ground-water flow below the Fallon Indian Reservation near the town of Stillwater, from 7 to 20 ft below land surface.

Morgan (1982) delineated seven hydrogeologic units near the town of Stillwater in the upper $200 \mathrm{ft}$ of unconsolidated sediments. From land surface downward, the units as described by Morgan (1982, p. 24-27) are (1) two upper aquifers of sand from the
Fallon Formation and Carson River channel sediments, (2) a confining bed of clay of the Sehoo Formation, (3) an aquifer consisting of sand of the Wyemaha Formation, (4) a confining bed tentatively correlated to the Eetza Formation, (5) a composite aquifer comprised of several thin aquifers separated by thin confining beds, and (6) a lower, poorly defined confining bed. Thicknesses shown by Morgan (1982, pl. 2) suggest that the upper aquifers and confining bed extend to depths of about $50 \mathrm{ft}$, which correspond to Glancy's (1986) shallow aquifer. The remaining hydrogeologic units correspond to Glancy's intermediate aquifer.

Tokunaga and Benson (1991) describe a similar sequence of aquifers and confining beds beneath the Fallon Indian Reservation (pl. 1). From the surface downward, the sequence comprises: a near-surface aquifer having poor water quality from land surface to about $16 \mathrm{ft}$ deep; a massive unit of Sehoo clay from 16 to $60 \mathrm{ft}$ deep; a sandy aquifer, having somewhat better water quality than the near-surface aquifer, from 60 to about $100 \mathrm{ft}$ deep and that is correlative with the Wyemaha Formation; a clay unit from about $100 \mathrm{ft}$ to $160 \mathrm{ft}$ deep; and an irregular sequence of sand, clay, and silt beds from $160 \mathrm{ft}$ to $300 \mathrm{ft}$ deep, correlative with the Paiute Formation and grading to massive clay below $300 \mathrm{ft}$. Again, the near-surface aquifer and confining bed correlate with Glancy's (1986) shallow aquifer, and the lower sequence correlates with Glancy's (1986) intermediate aquifer.

Olmsted and others (1984) also defined shallow, intermediate, and deep ground-water flow systems in studies of geothermal systems in the Soda Lake and Upsal Hogback areas. Their shallow system extends to about $800 \mathrm{ft}$ in depth, represents flow in the Quaternary alluvial deposits, and corresponds to Glancy's (1986) shallow and intermediate aquifers. Their intermediate system extends from about $800 \mathrm{ft}$ to about $4,200 \mathrm{ft}$ in depth, represents flow in semiconsolidated sediments of Tertiary age, and corresponds to Glancy's (1986) deep aquifer. The deep system extends from about $4,200 \mathrm{ft}$ to about $20,000 \mathrm{ft}$ in depth and represents flow in Tertiary volcanic rocks and pre-Tertiary consolidated rocks. The above depths apply specifically to the Soda Lakes geothermal area, but the flow-system boundaries are based on ages, lithologies, and hydrologic properties of geologic units that are found throughout the Carson Desert.

Although the flow systems described by Olmsted and others (1984) extend to greater depths than those of Glancy (1986), the boundary between unconsolidated Quaternary deposits and semiconsolidated Tertiary deposits could be used to define the boundary between Glancy's intermediate and deep aquifers throughout the Carson Desert. Because Glancy's 


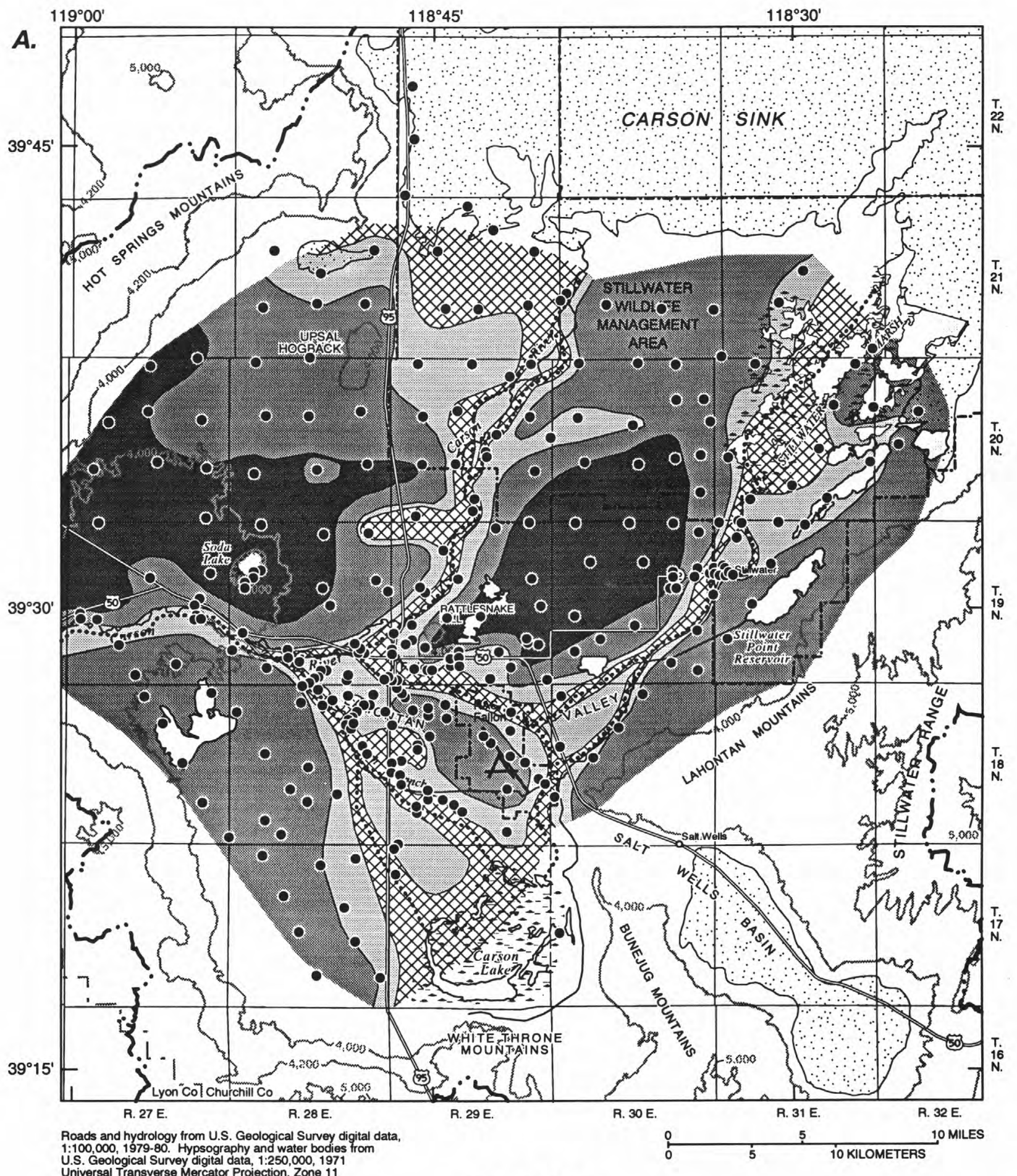

EXPLANATION

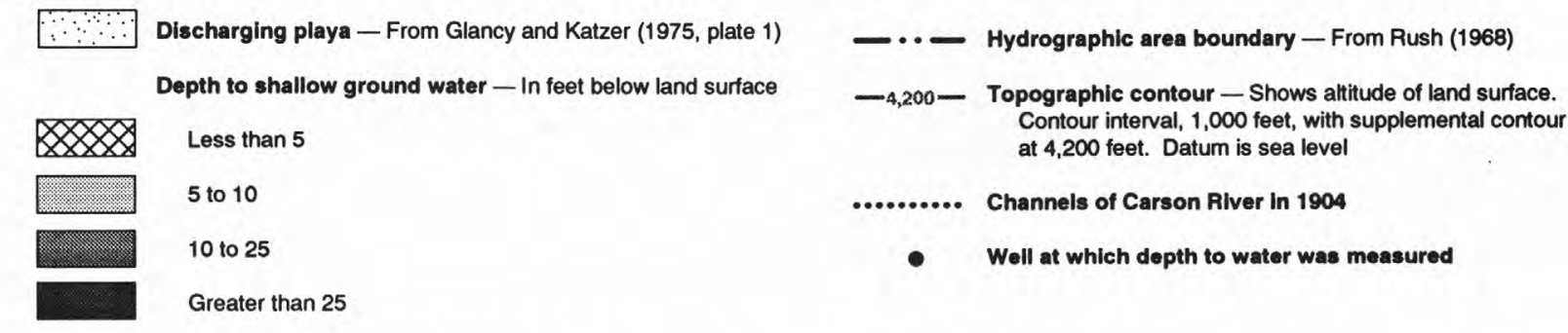

Figure 8. Depth to shallow ground water in (A) 1904 and (B) 1992. Modified from Seiler and Allander (1993, fig. 4); information for 1904 from Stabler (1904). 


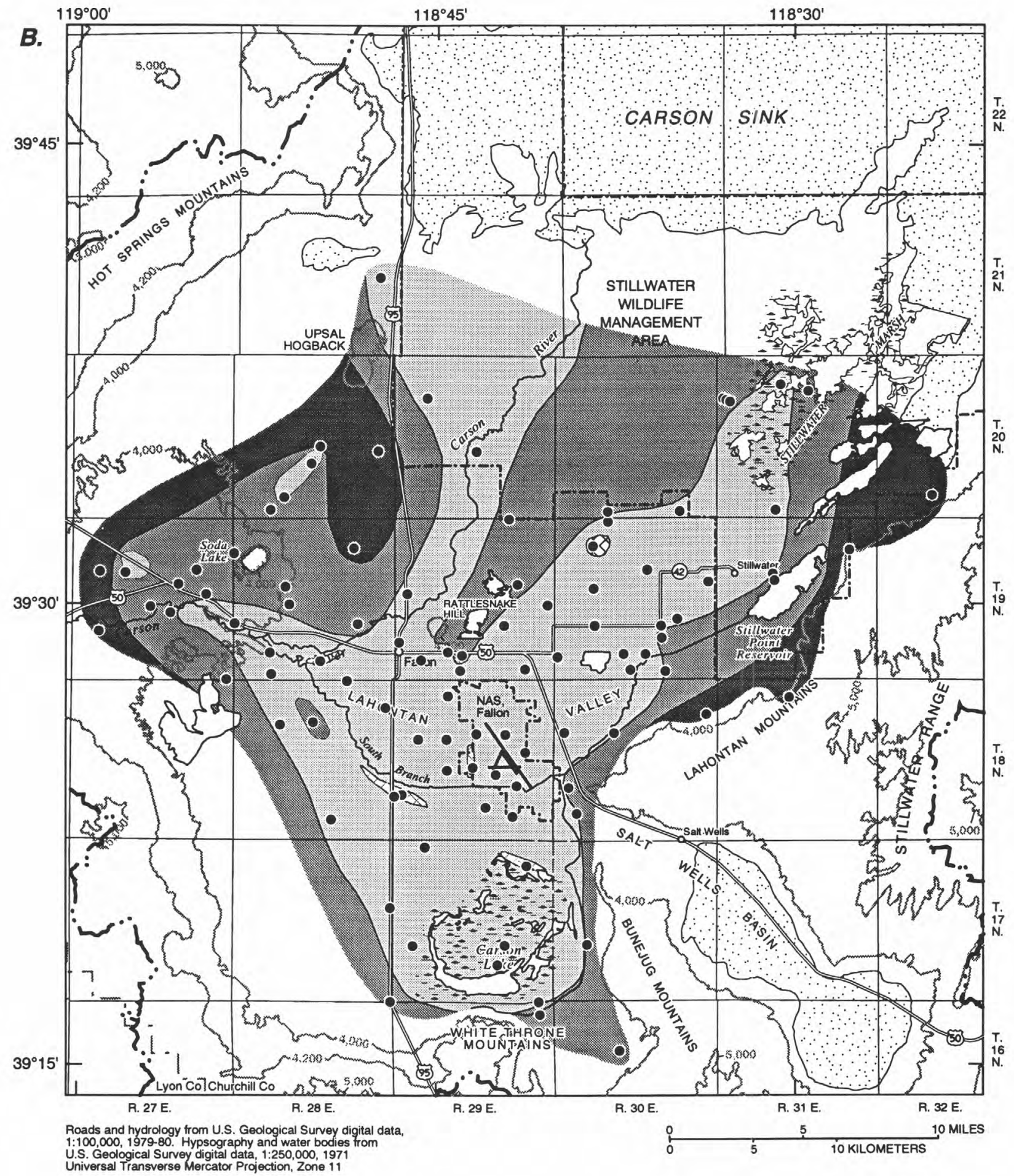

U.S. Geological Survey digital data, 1:250,000, 1971

Figure 8.-Continued 


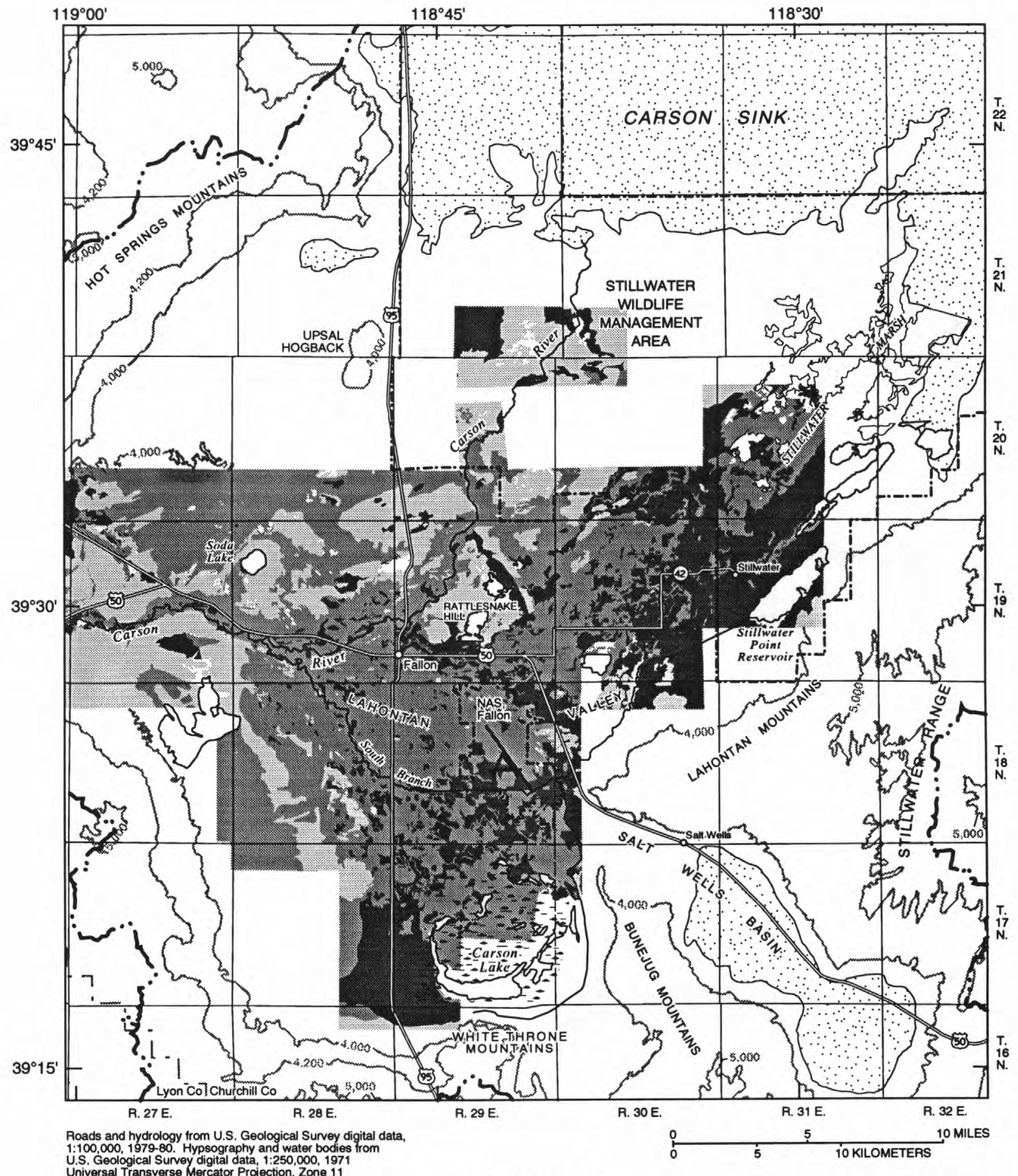

EXPLANATION

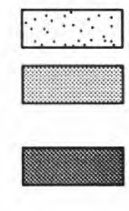

Discharging playa — From Glancy and Katzer (1975, plate 1)

Seasonal high water table more than 5 feet below land surface - Available water-holding capacity less than 8 inches

Seasonal high water table less than 5 feet below land surface - Available water-holding capacity less than 8 inches

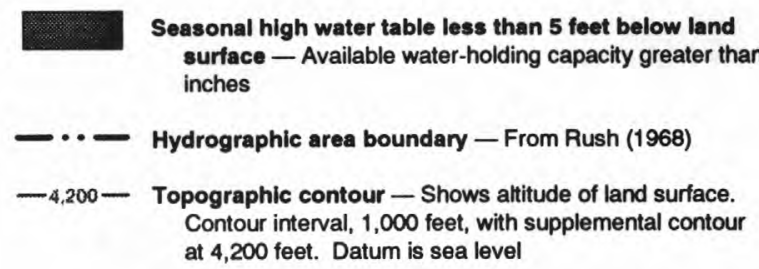

Figure 9. Depth to seasonal high water table and available water-holding capacity of soils. Mapped by Dollarhide (1975) and summarized by Bureau of Reclamation (1992a); digital data from Bureau of Reclamation (Charles Johnson, written commun., 1993). 
deep aquifer was described as alluvial, Tertiary volcanic rocks could represent a volcanic zone at the base of the deep aquifer that is interbedded with an upper sedimentary zone of the deep aquifer.

The above descriptions show that, although other aquifer systems can be delineated, Glancy's (1986) description of aquifers in the Carson Desert is common to most, and will be used in this report as the basis for conceptual models of the ground-water flow system. The near-surface zone overlying clay units of the Sehoo Formation can be an important refinement of Glancy's (1986) shallow aquifer because interaction between the surface-water and ground-water systems and evapotranspiration take place in this zone. A detailed compilation of lithologic and hydrologic data would refine the boundaries of this near-surface zone and determine its role in controlling shallow ground-water flow.

\section{Shallow Aquifer}

On the basis of water chemistry, Glancy (1986, p. 41) defined the shallow aquifer to extend from the water table, generally less than $10 \mathrm{ft}$ below land surface, to a depth of $50 \mathrm{ft}$. Glancy (1986, p. 41-46) noted that water from the shallow aquifer is generally hard (hardness greater than $70 \mathrm{mg} / \mathrm{L}$ ). This contrasts with generally soft ground water (hardness less than $25 \mathrm{mg} / \mathrm{L}$ ) in the intermediate aquifer deeper than 50 $\mathrm{ft}$ below land surface. Using 1980 census data, Glancy (1986, p. 33) estimated that from 3,000 to 4,000 wells pumped water from the shallow aquifer. From 1985 to 1993, records of the Nevada State Engineer show that an additional 300 wells were drilled into the shallow aquifer. If about 200 wells were drilled from 1980 to 1985 , in 1993, as many as 4,500 wells could pump from the shallow aquifer. The Churchill County Health Department maintains records of domestic wells, but has not tabulated the number of active wells (Richard Elloyas, Churchill County Health Department, oral commun., 1993).

The aquifer is characterized by abrupt changes in lithology and water quality, both horizontally and vertically. These characteristics are inherited from the constantly changing depositional environments during Pleistocene time that produced a complex mixture of river-channel, delta, flood-plain, shoreline, lake-bed, and sand-dune deposits. Because deltas of the Carson River formed in the western part of the basin, sediments in the shallow aquifer are coarser to the west and become increasingly finer toward the east.
In general, near the center of the basin, sediments of the Fallon and Sehoo Formations form the shallow aquifer. This generalization does not apply near the perimeter of the basin where older formations of Quaternary age are exposed (pl. 3).

Glancy $(1986$, p. 38) used data from about 430 wells in the shallow aquifer to show that the maximum specific capacity is generally less than 50 $\mathrm{gal} / \mathrm{min}$ for every foot of drawdown east of Fallon, and is as high as $70 \mathrm{gal} / \mathrm{min}$ for every foot of drawdown, although variable, west of Fallon. Glancy (1986, p. 37) reports that transmissivities of the shallow aquifer also vary greatly, ranging from less than $2,000 \mathrm{ft}^{2} / \mathrm{d}$ to $15,000 \mathrm{ft}^{2} / \mathrm{d}$, and could be less than $2,000 \mathrm{ft}^{2} / \mathrm{d}$ at many locations. Using the relation applied by Glancy (1986, p. 37) between specific capacity of a well and aquifer transmissivity, data from 63 wells drilled since 1985 show that aquifer transmissivity is less than $2,000 \mathrm{ft}^{2} / \mathrm{d}$ at about 90 percent of the wells.

Water-level altitudes in the shallow aquifer determined by Seiler and Allander (1993, pl. 1) for 1992 are shown in figure 10 and show virtually the same configuration determined by Glancy (1986, p. 42) for the period 1975-78. The contours show that shallow ground water flows northeastward in areas north of Fallon, with an average gradient of about 9 $\mathrm{ft} / \mathrm{mi}$, and flows southeastward in areas south of Fallon, with an average gradient of about $6 \mathrm{ft} / \mathrm{mi}$ (Seiler and Allander, 1993, p. 17). However, detailed studies have shown that directions of shallow groundwater flow vary greatly and are controlled locally by the presence of canals and drains and by irrigation practices on individual fields (Lico and others, 1987, p. 93; and Lico, 1992, p. 8). Also, Seiler and Allander (1993, p. 17) indicate that in the Carson Desert, faults can locally control the configuration of the water table.

The configuration of the water table in 1992 (fig. 10) indicates that recharge from the Carson River and irrigated lands drives flow from west to east and that the Carson Lake and Stillwater/Carson Sink areas are locations of regional discharge of shallow ground water. Carson Lake receives flow from irrigated lands to the northwest and flow from Bass Flat and surrounding mountains from the south and east. A broad ground-water divide exists just east of the Naval Air Station near Fallon (fig. 10). Springs south of Salt Wells are higher than ground-water levels in the Carson Desert indicating that shallow ground water does not flow east past the low topographic divide between the Carson Desert and Salt Wells Basin (Seiler and Allander, 1993, p. 17). The Stillwater/Carson Sink area receives flow from 


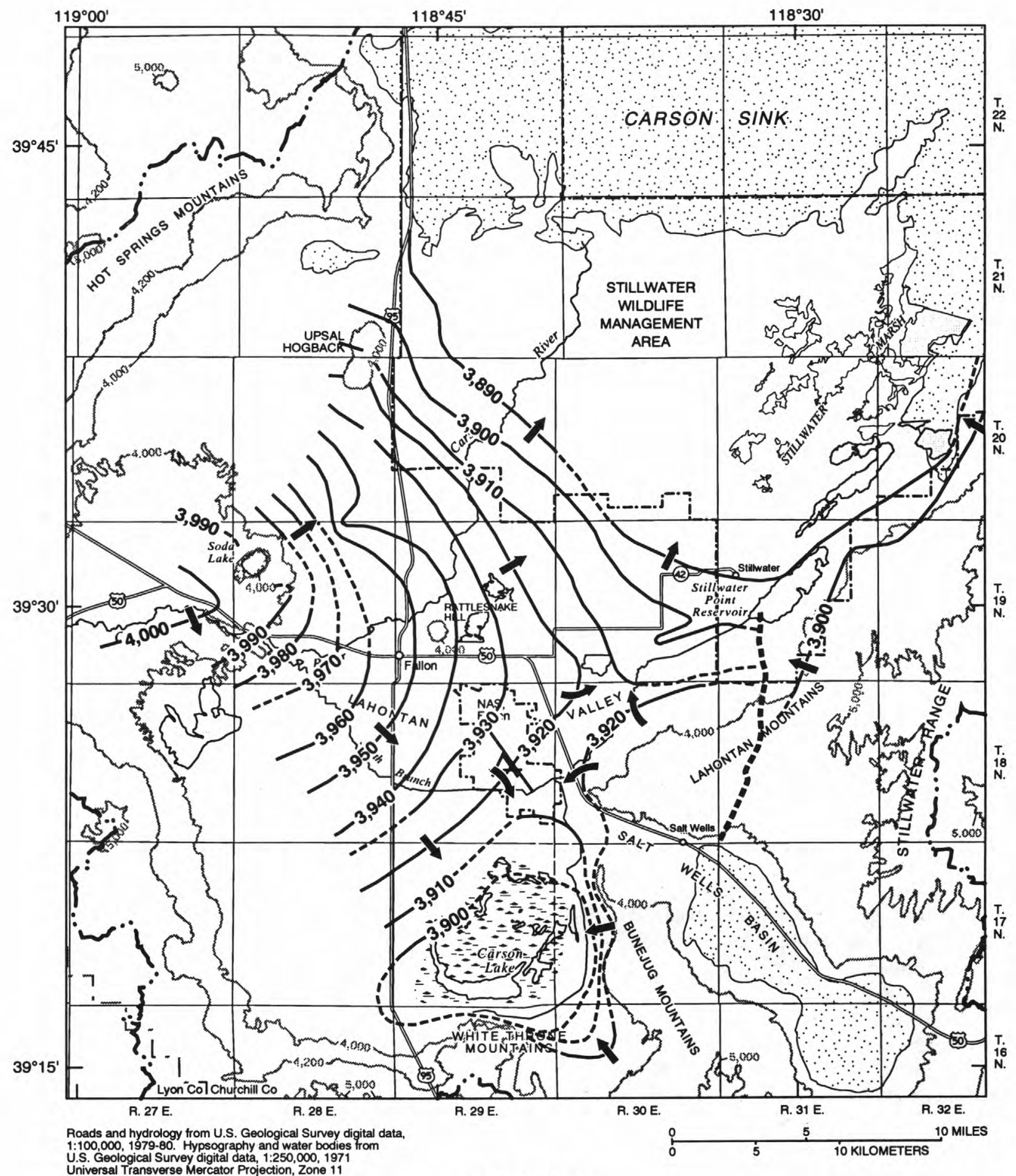

EXPLANATION
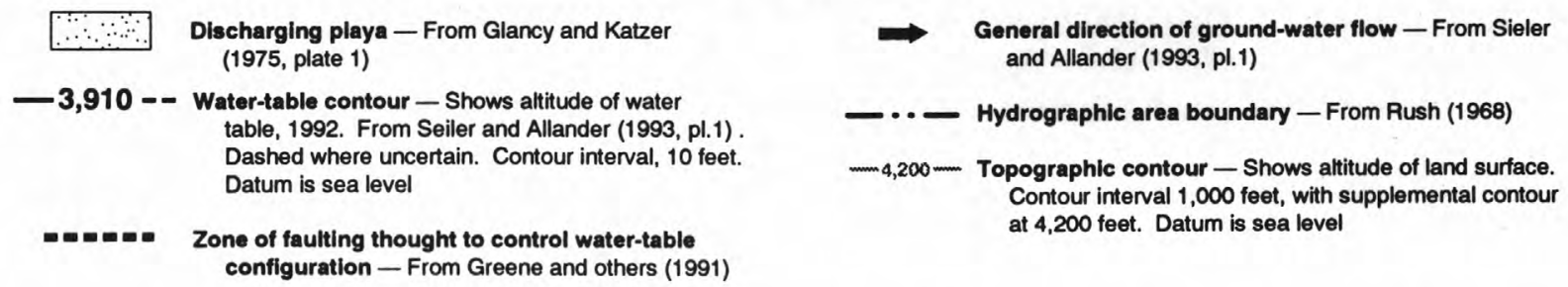

Figure 10. Water-level altitude and general direction of ground-water flow in shallow aquifer. Modified from Seiler and Allander (1993, pl. 1). 
irrigated lands to the southwest and from the Stillwater Range, indicating that the Stillwater Range is a barrier to eastward ground-water flow in the shallow aquifer.

Water-level fluctuations show that the shallow aquifer is recharged by surface-water seepage during the irrigation season. Lico $(1992$, p. 8) states that, even near areas of ground-water discharge, canals and drains recharge the shallow aquifer. Water-level fluctuations in the shallow aquifer closely match the seasonal fluctuation in surface-water flow for irrigation, but decrease in amplitude and lag behind fluctuations in surface-water flow with increasing distance from distribution channels and irrigated lands (Glancy, 1986, figs. 18-21).

Near irrigated lands, seasonal water-level fluctuations are generally greater than $2 \mathrm{ft}$ and as much as 4 to $6 \mathrm{ft}$ in amplitude. However, few measurements of ground-water fluctuations beneath irrigated fields are available, so the timing of seasonal water-level maximums directly beneath irrigated fields is not well known. Near Carson Lake, Lico and others (1986, fig. 4) show that the vertical gradient within the shallow aquifer is downward during the irrigation season, but that the gradient decreases and then reverses to upward during winter months. Waterlevel decline during winter months is generally limited by the depth of drains, which ranges from 4 to $8 \mathrm{ft}$ below land surface over most irrigated areas (Bureau of Reclamation, 1992a, p. 12). During drought years, ground-water levels drop below drain depths and many drains cease to flow. In areas distant from stream channels and irrigated lands, seasonal water levels fluctuate from 0.5 to less than $2 \mathrm{ft}$ (Glancy, 1986, p. 39). Similar ranges of fluctuations were measured in the Carson Desert during 1992 (Seiler and Allander, 1993, p. 14).

A large part of seepage losses from canals and laterals, and percolation to the shallow aquifer beneath irrigated fields could take place through relict channels of the Carson River, locally called "Fernley sand stringer" channels. These channels act as drains and convey water considerable distances (Bureau of Reclamation, 1987b, p. 21). Dollarhide (1975, p. 27, 28) mapped a Fernley Series soil, which consists of sand channels to depths of 60 in. below land surface in the Fallon Formation (pl. 3). The sand stringers produce notable areas of decreased crop production during times of drought, providing evidence that they are zones of low water retention and could act as drains in the near-surface zone of the shallow aquifer.

Relict channels of the Carson River are also found in deeper formations of Quaternary age. Plate 3 shows channels formed during deposition of the Fallon and Sehoo Formations as mapped by Morrison (1964, pl. 11). The channels mapped by Morrison (1964) are generally larger than those mapped by Dollarhide (1975) and thus could extend to greater depths. Buried channels similar to those mapped on the surface are no doubt present beneath the valley floor. The relict channels probably represent preferential zones of shallow ground-water flow.

Seiler and Allander (1993, p. 11-14) noted that water-level changes from the mid-1970's to 1992 have been small in most areas of the Carson Desert. In both the Sierra Nevada and the Carson Desert, 1979 and 1981 had normal or below-normal precipitation. The years of 1982 and 1983 had above-normal precipitation, and, since 1986, runoff from the Sierra Nevada has been below normal. Accordingly, water levels rose slightly more than $2 \mathrm{ft}$ from 1977 to 1984 , followed by water-level declines of about $1 \mathrm{ft}$ in most areas and slightly more than $4 \mathrm{ft}$ in the Stillwater area from 1988 to 1992 . Water levels in 1992 declined less than $1 \mathrm{ft}$ in most areas and more than $2 \mathrm{ft}$ at one location about $5 \mathrm{mi}$ northeast of Fallon compared with 1977 water levels.

Water-level changes have been documented after changes were made in the irrigation distribution system. About $13 \mathrm{mi}$ south of Fallon, water levels were about $4 \mathrm{ft}$ higher in 1992 compared to the 1977 water level, possibly because of increased use of a nearby canal (Seiler and Allander, 1993, p. 14). Water levels declined more than $10 \mathrm{ft}$ from 1984 to 1992 adjacent to the T-Line Canal after a 1.5-mile section was lined with concrete (Seiler and Allander, 1993, p. 15). Thus, changes in the use of irrigation canals can affect water levels in the adjacent shallow aquifer.

\section{Intermediate Aquifer}

The intermediate aquifer is estimated to store about 2.5 million acre-ft of fresh ground water (Glancy, 1986, p. 51), which makes it possibly the largest aquifer containing potable ground water in the Carson Desert. Before the mid-1970's, water from the intermediate aquifer was not generally known to be suitable for domestic use, and therefore, most domestic wells tapped the shallow aquifer. Glancy (1986, p. 51), reports that only about 100 wells tapped the intermediate aquifer in 1979. Data from drillers' logs stored in USGS data bases show that from 1985 to 1993 , more than 500 wells were drilled into the intermediate aquifer. Thus, if 400 wells were drilled into the intermediate aquifer from 1979 to 1985 , as many as 1,000 wells might exist that withdraw water from the intermediate aquifer. 
The boundary between the shallow and intermediate aquifer was based on an observed change from hard ground water in the shallow aquifer to soft ground water in the intermediate aquifer, generally at depths of about $50 \mathrm{ft}$ below land surface (Glancy, 1986). However, Glancy (1986, pl. 2) shows that ground water west of Soda Lake in the intermediate aquifer is almost as hard as that in the shallow aquifer (Glancy, 1986, pl. 1). This suggests that a distinct boundary between the shallow and intermediate aquifers may not exist west of Soda Lake or that it could be deeper than $50 \mathrm{ft}$.

The boundary between the intermediate and deep aquifers is also based on an observed change in water quality. The intermediate aquifer, as defined by Glancy (1986), contains primarily fresh ground water, whereas the deep aquifer contains more saline ground water (Glancy, 1986, p. 51). The boundary between the intermediate and deep aquifers ranges from 500 to $1,000 \mathrm{ft}$ below land surface. The large range given by Glancy (1986) for the lower boundary of the intermediate aquifer is caused by the lack of wells, and, thus, lack of data on water quality, deeper than $500 \mathrm{ft}$. Michael S. Lico and Ralph L. Seiler (written commun., 1993) report that water quality at a depth of $1,700 \mathrm{ft}$ near the Naval Air Station, Fallon, is similar to nearby wells in the intermediate aquifer. Thus, the lower boundary of the intermediate aquifer, as defined by water quality, could be more than $1,000 \mathrm{ft}$ below land surface.

As discussed previously, the boundary between sediments of Quaternary and Tertiary age could also be used to define the bottom of the intermediate aquifer. Because the Tertiary deposits are semiconsolidated to consolidated, effective porosity and permeability of these deposits are lower than those of the unconsolidated Quaternary sediments (Olmsted and others, 1984, p. 25, 26). Thus, ground water could move more slowly through the Tertiary deposits, increasing the time for ground water to react with aquifer materials and increasing the resulting dissolved-solids concentration of the ground water. More data might determine whether water quality changes as lithology and age of the basin-fill deposits change. If water quality depends on the composition and age of basin-fill deposits, the top of the Tertiary basin-fill deposits could be used to define the bottom of the intermediate aquifer and delineate the extent and volume of potable ground water in the basin.

The boundary between Quaternary and Tertiary deposits is difficult to determine. However, it can be distinguished by an increase in induration and amount of reworked tuffaceous volcanic material or by fossils found in drill cuttings. Such information shown on plate 1 is used to generate the geologic sections shown on plate 2 which indicate that the base of Quaternary basin-fill deposits could be about $1,600 \mathrm{ft}$ below land surface near Soda Lake (pl. 2, section A$\mathrm{A}^{\prime}$ ), as deep as 2,500 $\mathrm{ft}$ near the town of Stillwater (pl. 2, section B-B'), and could range in depth from 1,800 to possibly $2,500 \mathrm{ft}$ below land surface near Carson Lake (pl. 2, section D-D').

Glancy (1986, p. 54) suggests that the upper part of the intermediate aquifer correlates with deposits of the Wyemaha Formation. Morrison (1964, p. 117) states that this formation yields large amounts of potable water to wells from sandy gravel near the Carson River west of Fallon. Toward the center of the basin, these deposits become more sandy. Near Carson Lake and Stillwater WMA, they become silty and clayey, and yield small amounts of nonpotable water. Most wells drilled into the intermediate aquifer before 1980 were perforated from 90 to $120 \mathrm{ft}$ in depth (Glancy, 1986, p. 50). Glancy suggests that the consistent interval of perforation indicates a zone of permeable materials in this depth range.

Data from 544 wells drilled into the intermediate aquifer since 1985 show that more than 90 percent have open intervals of less than $10 \mathrm{ft}$. This suggests that drillers attempted to perforate wells near thin permeable zones. Figure 11 shows the locations of wells perforated from 50 to $200 \mathrm{ft}$ in depth since 1985. In general, wells perforated from 50 to $80 \mathrm{ft}$ below land surface are west of Fallon (fig. 11A) and wells perforated from 80 to $200 \mathrm{ft}$ below land surface are located in the western part of the basin along the channel of the Carson River up to $5 \mathrm{mi}$ southeast of Soda Lake (fig. 11B). The majority of wells near the center of the basin are perforated from 80 to $140 \mathrm{ft}$ below land surface. No wells were drilled in the intermediate aquifer near the Stillwater or Carson Lake areas. Zones of high permeability in the intermediate aquifer and, thus, zones of preferential ground-water flow could be present at depths from 50 to $200 \mathrm{ft}$ along the channel of the Carson River west of Fallon and from 80 to $140 \mathrm{ft}$ near the center of the basin.

Glancy $(1986$, p. 54) reports that transmissivities in the intermediate aquifer are generally less than $2,000 \mathrm{ft}^{2} / \mathrm{d}$. The relation between specific capacity of a well and aquifer transmissivity used by Glancy (1986, p. 37) was applied to data from drillers' logs for 132 wells drilled since 1985 . Just as reported by Glancy (1986), aquifer transmissivity was less than $2,000 \mathrm{ft}^{2} / \mathrm{d}$ at more than 90 percent of the wells.

In the intermediate aquifer, water-level altitudes measured by Glancy $(1986$, p. 53) have a configuration similar to that of the shallow aquifer. Thus, ground water in the intermediate aquifer flows in the same general direction as that in the shallow aquifer. 
However, the horizontal gradient is not as steep as in the shallow aquifer (Glancy, 1986, p. 51).

In the intermediate aquifer, water-level fluctuations also were shown by Glancy (1986, p. 43) to closely follow fluctuations in surface-water flow near river channels and major canals. However, the amplitude of the fluctuations was much less than in the shallow aquifer, usually less than $1 \mathrm{ft}$. Few measurements of water levels in the intermediate aquifer have been made since the mid-1970's. Seiler and Allander (1993, Appendixes 1 and 3) measured water levels at several wells tapping the intermediate aquifer during 1992. These measurements show that water-level changes from the mid-1970's to 1992 in the intermediate aquifer also were small. West of Fallon and north of Soda Lake, water levels declined as much as $3 \mathrm{ft}$. In areas distant from irrigation, water levels declined less than $1 \mathrm{ft}$, remained about the same, or rose less than $1 \mathrm{ft}$.

Differences in water-level altitude between potentiometric maps of the two aquifers (Glancy, 1986, p. 54) demonstrate potential for downward ground-water flow from the shallow to the intermediate aquifer in the western part of the basin, and potential for upward ground-water flow from the intermediate aquifer to the shallow aquifer in the remainder of the basin. Areas having potential for upward and downward flow between the shallow and intermediate aquifers are shown on figure 12, although exceptions exist to this general trend. Ground-water ages, calculated by carbon-14 dating, show that water in the intermediate aquifer is on the order of hundreds of years old west of Soda Lake, slightly more than 1,000 years old near Fallon, and several thousand years old more than about $5 \mathrm{mi}$ northeast of Fallon (Michael S. Lico and Ralph L. Seiler, U.S. Geological Survey, written commun., 1993).

Glancy (1986, p. 55) shows that water levels west of Fallon are $10 \mathrm{ft}$ higher in the shallow aquifer than in the intermediate aquifer. However, no value for the gradient was calculated. Vertical gradients near the Soda Lake/Upsal Hogback area range from about 0.01 to $0.07 \mathrm{ft} / \mathrm{ft}$ for downward flow and from 0.02 to $0.2 \mathrm{ft} / \mathrm{ft}$ for upward flow (Olmsted, 1985, table 2). Near the Stillwater WMA, except at one site just north of Stillwater Point Reservoir, vertical gradients reported by Morgan (1982, pl. 3) are upward and range from 0.03 to $0.2 \mathrm{ft} / \mathrm{ft}$. Data presented by Seiler and Allander (1993, Appendixes 1 and 3) allow calculation of vertical gradients in 1992 similar to those calculated by Olmsted (1985) in the Soda Lake/Upsal Hogback area. Vertical gradients in 1992 ranged from 0.1 to $0.09 \mathrm{ft} / \mathrm{ft}$ in the downward direction about $2 \mathrm{mi}$ southwest of Soda Lake and north of Rattlesnake Hill and were about $0.16 \mathrm{ft} / \mathrm{ft}$ in the upward direction near the Naval Air Station, Fallon.

Unpublished data (Frank Olmsted, written commun., 1992) show that the vertical gradient in both the downward and upward directions increases during wet years, suggesting that a direct hydraulic connection exists between the two aquifers. The vertical gradient is thought to increase with depth in the intermediate aquifer near the town of Stillwater (Morgan, 1982, p. 44). Franklin H. Olmsted (U.S. Geological Survey, written commun., 1992) states that both the magnitude and direction of vertical flow in the intermediate aquifer can change with depth.

Areally, few measurements of vertical gradient exist between the area with a downward potential for vertical flow and areas near Upsal Hogback, the town of Stillwater, and Carson Lake where a potential for upward flow has been documented by Olmsted (1985), Morgan (1982), and Seiler and Allander (1993, pl. 1). However, vertical gradients are probably transitional from downward to upward. Additional data would allow more precise determination of the direction and magnitude of the vertical gradient and the location of ground-water flow between the shallow and intermediate aquifer.

\section{Deep Aquifer}

Information about the deep aquifer is limited by the number of deep wells drilled in the basin. Glancy (1986, p. 60) states that it underlies the entire basin at depths greater than 500 to $1,000 \mathrm{ft}$ below land surface and ranges from a few hundred feet to greater than $8,000 \mathrm{ft}$ in thickness. Glancy (1986, p. 60) also states that the deep aquifer contains more than $1,000 \mathrm{mg} / \mathrm{L}$ and locally more than $5,000 \mathrm{mg} / \mathrm{L}$ dissolved solids.

If a sedimentary zone of the deep aquifer correlates with semiconsolidated sediments of Tertiary age, drill-hole data used to develop geologic sections on plate 2 indicate that the depth to the sedimentary zone could range from about a few hundred feet near the Hot Springs Mountains to more than $3,000 \mathrm{ft}$ near Carson Lake. Its thickness could range from 400 to more than $2,000 \mathrm{ft}$. The base of the sedimentary zone of the deep aquifer is poorly defined because the unit is interbedded with underlying volcanic rocks of Tertiary age. The underlying Tertiary volcanic rocks could represent a volcanic zone over 4,000 ft thick at the base of the Tertiary sediments within the deep aquifer. However, additional data are needed to confirm this possibility. 


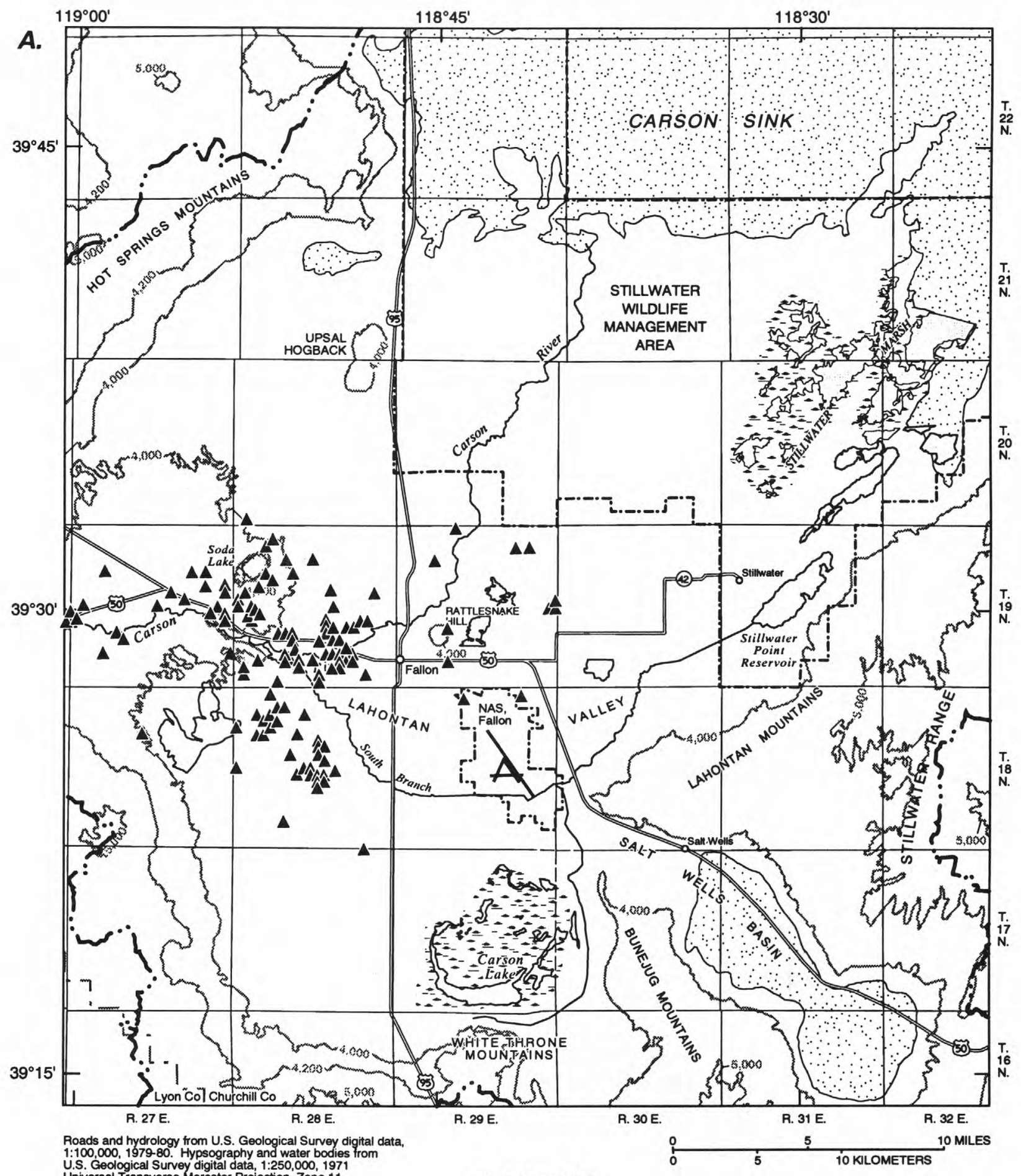

EXPLANATION
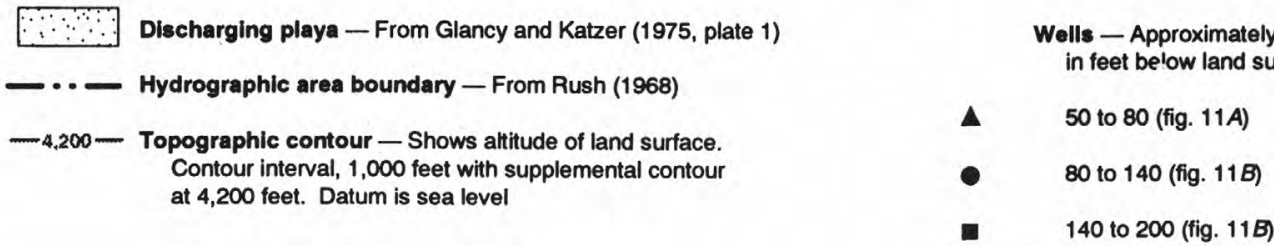

Figure 11. Wells drilled in intermediate aquifer since 1985, grouped on basis of depth of open interval. 


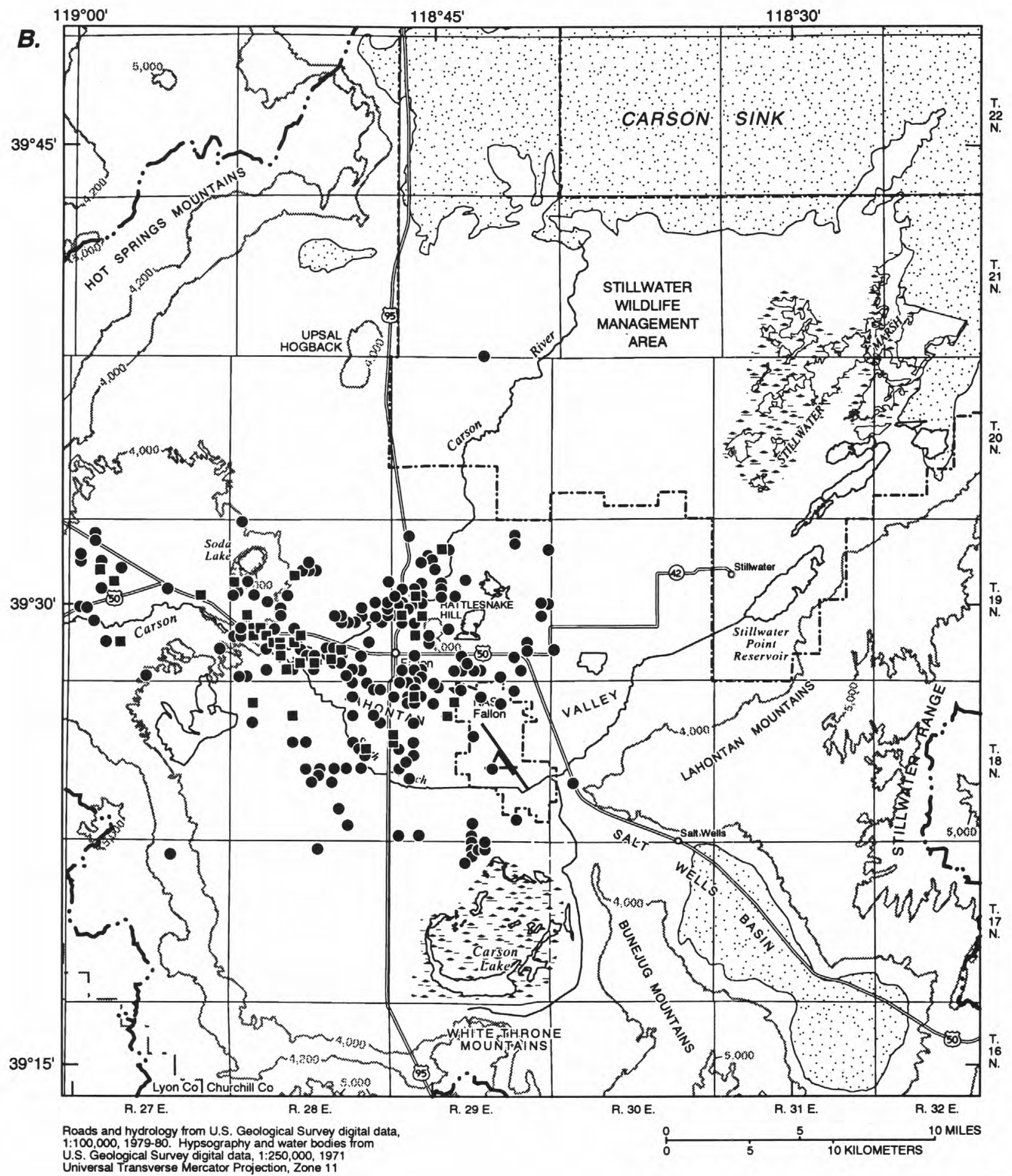

Figure 11.-Continued 


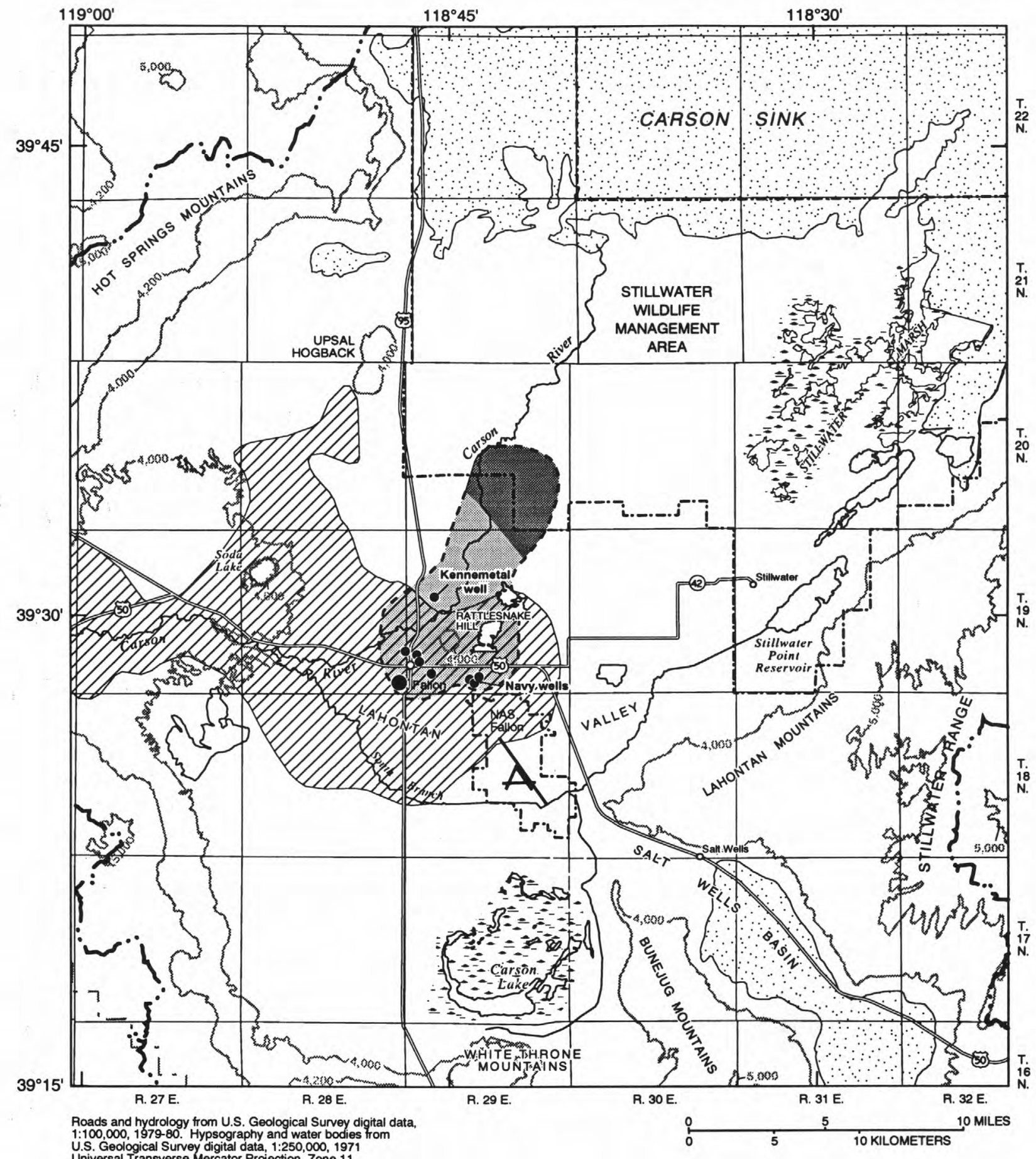

U. $100,000,1979-80$. Hypsography and water bodies from

Universal Transverse Mercator Projection, Zone 11

\section{EXPLANATION}

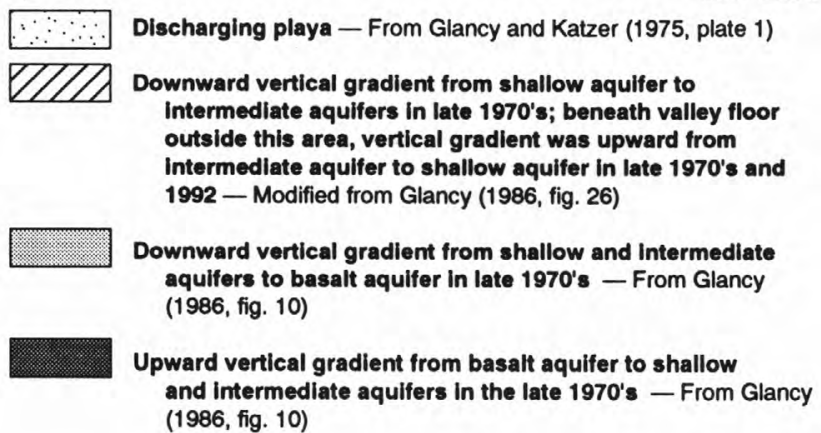

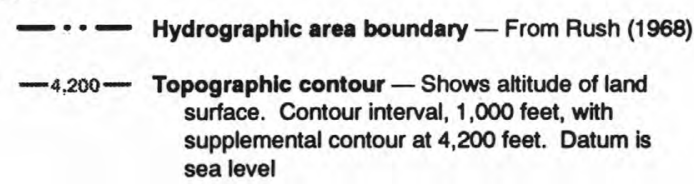

Extent of basalt aquifer at depth of 600 feet From Glancy (1986, fig. 2)

Well in basalt aquifer where water-level fluctuations have been measured from 1971 to 1992 (see fig. 13)

- Well where withdrawals are made from the basalt aquifer for municipal and industrial use

Figure 12. Areal extent of basalt aquifer and directions of vertical gradient among shallow, intermediate, and basalt aquifers. 


\section{Basalt Aquifer}

The basalt aquifer is the main source of water for municipal wells of Fallon and the Naval Air Station, Fallon, and for industrial use by Kennemetal, Incorporated. Glancy (1986, p. 10) showed the approximate three-dimensional limits of the basalt aquifer, using geophysical data and the locations of wells that tap the aquifer (fig. 12). The basalt that forms the aquifer is exposed at Rattlesnake Hill. It is found at depths of 400 to $600 \mathrm{ft}$ to the south, west, and northwest of Rattlesnake Hill, at depths of about 200 to $300 \mathrm{ft} 5 \mathrm{mi}$ northeast of Rattlesnake Hill, but has not been encountered by wells more than $700 \mathrm{ft}$ deep south and east of Rattlesnake Hill (Glancy, 1986 , p. 8, 10). Direct information about the aquifer is limited to only its shallowest part because no wells tap the basalt to depths greater than about $600 \mathrm{ft}$ below land surface. Geophysical data show the approximate lateral extent of the basalt aquifer at $600 \mathrm{ft}$ below land surface; however, the data are uncertain toward the northwest (Glancy, 1986, p. 15). Between 1,000 and 4,000 ft, the basalt decreases in lateral extent to a vertical volcanic neck about $1 \mathrm{mi}$ in diameter.

Basalt forming the aquifer ranges from dense, fractured lava flows to basalt rubble and cinders in zones between the flows. Wells tapping the aquifer produce more than $1,000 \mathrm{gal} / \mathrm{min}$ with about $3 \mathrm{ft}$ of drawdown with little or no measurable drawdown at nearby observation wells. The unit as a whole has a high transmissivity, which ranges from about 4,000 to $170,000 \mathrm{ft}^{2} / \mathrm{d}$ (Glancy, 1986, p. 15, 18).

In the mid-1970's, water levels in the basalt aquifer indicated a nearly flat potentiometric surface at an altitude ranging from 3,920 to $3,922 \mathrm{ft}$ above sea level with possibly a small gradient toward the northeast. Lico and Seiler (written commun., 1993) present carbon-14 data for ground water in the basalt aquifer showing that the estimated age increases from less than 4,000 years to about 8,000 years old toward the northeast. This also indicates flow in that direction. Water levels in both the shallow and intermediate aquifers ranged from $30 \mathrm{ft}$ above to as much as $20 \mathrm{ft}$ below those in the basalt aquifer in the mid1970's. The distribution of these water levels indicates a potential in the southwestern part of the basalt aquifer for recharge from the shallow and intermediate aquifers, and a potential in the northeastern part of the basalt aquifer for discharge to the shallow and intermediate aquifers (fig. 12) (Glancy, 1986, p. 18, 27).

Water-level fluctuations in the basalt aquifer show annual declines caused by pumping in summer months, followed by annual recoveries during winter.
In the mid-1970's, the fluctuations ranged from 1 to $2 \mathrm{ft}$. Seasonal fluctuation also was measured at wells north of Rattlesnake Hill more than $5 \mathrm{mi}$ from heavily pumped wells, indicating the high transmissivity of the basalt. Figure 13 shows a long-term decline of about $10 \mathrm{ft}$, from a pre-pumping altitude of about $3,927 \mathrm{ft}$ (Glancy, 1986, p. 30) to about $3,917 \mathrm{ft}$ in 1992. Thus, the area with downward vertical gradient from the shallow and intermediate aquifer to the basalt aquifer is probably larger than that determined by Glancy (1986) in the mid-1970's, as shown on figure 12 .

Withdrawals from the basalt aquifer have in creased from about 1,700 acre-ft/yr in the 1970's to about 3,000 acre-ft/yr in 1992 (Larry White, City of Fallon, and Richard Fields, Naval Air Station, Fallon, written commun., 1993). A relation developed by Glancy (1986, p. 30) between pumpage and head decline in the basalt aquifer is in agreement with the observed pumpage and water-level decline in 1992 (fig. 14). These data support Glancy's (1986, p. 30) analysis and the relations among pumpage, recharge to the basalt aquifer, pumping-induced recharge, and discharge from the basalt aquifer.

The continued decline of water levels in the basalt aquifer combined with only slight declines in water levels in the shallow and intermediate aquifers have increased the potential for recharge from the shallow and intermediate aquifers to the basalt aquifer.

Basalt forming the aquifer was emplaced contemporaneously with the deposition of basin-fill sediments of Quaternary age. Thus, during high lake stands, deposits directly in contact with the basalt were probably well-sorted beach sands and gravel. These sedimentary deposits could provide conduits for recharge to the basalt aquifer. However, the actual flow paths for recharge to the basalt aquifer remain largely unknown.

\section{Geothermal Aquifers}

Geothermal aquifers in the Carson Desert have been identified in the Soda Lake/Upsal Hogback area (Olmsted and others, 1984), near Stillwater WMA (Morgan, 1982), near Carson Lake (Katzenstein and Bjornstad, 1987), and near Salt Wells (Geothermal Resources Council, 1985). The geothermal flow systems at Soda Lake/Upsal Hogback and Stillwater WMA have been described in detail by Olmsted and others $(1975,1984)$ and Morgan (1982). Total geothermal upflow beneath the floor of the Carson Desert could be as much as 4,000 acre-ft/yr. 


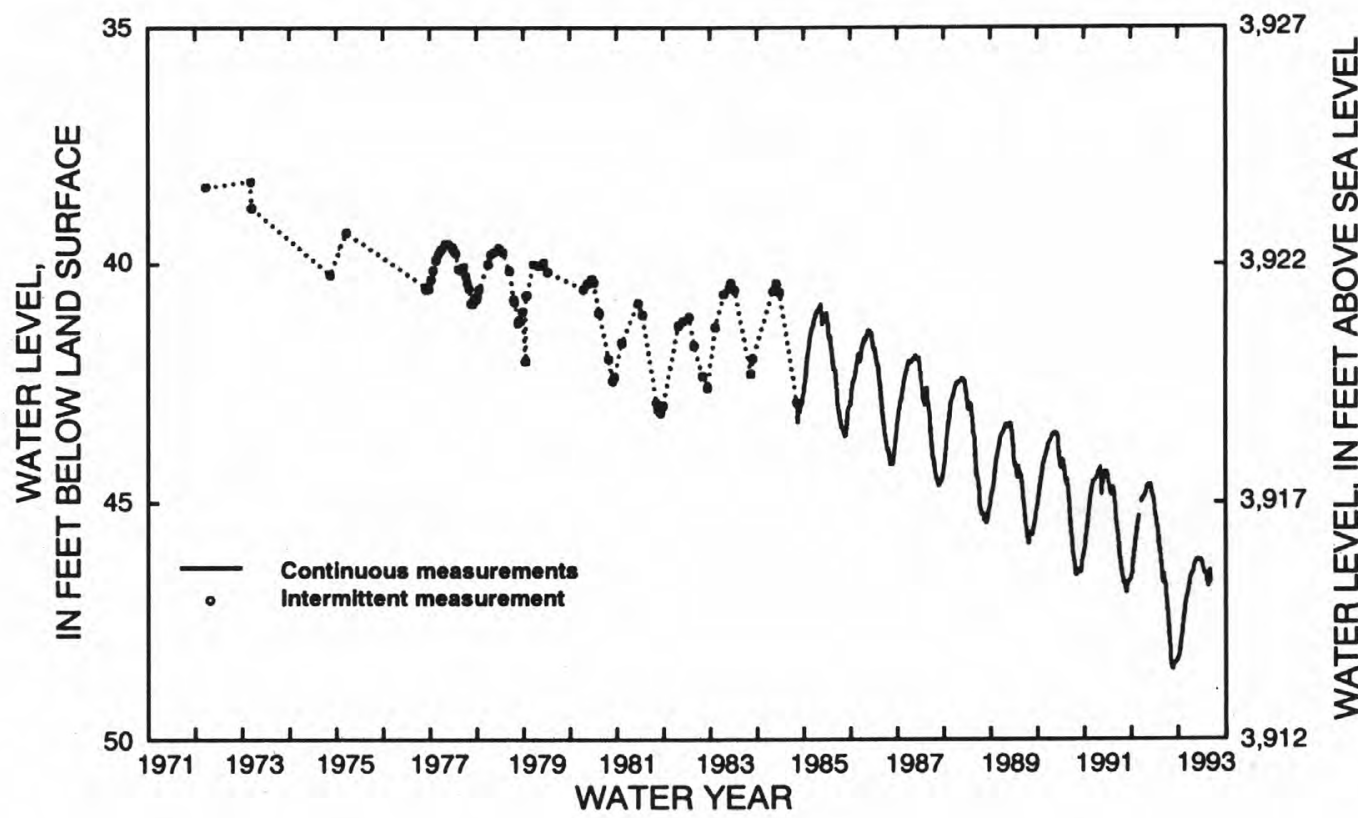

Figure 13. Water-level fluctuations from 1971 to 1992 in well completed in basalt aquifer. Well location shown in figure 12.

Near Soda Lake, geothermal water rises from depths greater than $10,000 \mathrm{ft}$, into the intermediate aquifer to within $65 \mathrm{ft}$ of land surface. Geothermal water is then mixed with nonthermal water of the intermediate aquifer and moves toward the Carson Sink (Olmsted and others, 1984, p. 1). Near Soda Lake, upward flow of geothermal water is an estimated 800 acre-ft/yr (Olmsted and others, 1984, p. 31). Near Upsal Hogback, an estimated 700 acre-ft/yr of geothermal water rises to about $800 \mathrm{ft}$ below land surface, where it then moves laterally through basalt flows associated with Upsal Hogback (Olmsted and others, 1984, p. 2). The source of geothermal water at both areas is ground water that was subjected to considerable evaporation before deep circulation (Olmsted and others, 1984, p. 76). Near Soda Lake the period of circulation is estimated to be from 3,400 to 34,000 years, and geothermal water was dated to be from 25,000 to 35,000 years old at Upsal Hogback (Olmsted and others, 1984, p. 2).
In the Stillwater area, geothermal water also rises from depths of greater than $10,000 \mathrm{ft}$ into both the shallow and intermediate aquifers to depths as shallow as $30 \mathrm{ft}$ below land surface (Morgan, 1982, pl. 2). The source of the geothermal water is probably local precipitation that was recharged along the front of the Stillwater Range and that rises along fault conduits to shallow depths (Morgan, 1982, p. 88-89). Olmsted and others $(1975$, p. 96$)$ estimate geothermal upflow to be about 2,500 acre-ft/yr, whereas Morgan (1982, p. 82) estimates it to be about 1,400 acre-ft/yr.

Much less is known about the geothermal systems near Carson Lake and Salt Wells. Near Carson Lake, geothermal water rises from depths of greater than $8,000 \mathrm{ft}$ upward into the deep and intermediate aquifers along fault planes to $1,000-1,500 \mathrm{ft}$ below land surface (Katzenstein and Bjornstad, 1987, p. 17). Near Salt Wells, a well tapped geothermal water at a depth of $700 \mathrm{ft}$, but little else is known about the system. 

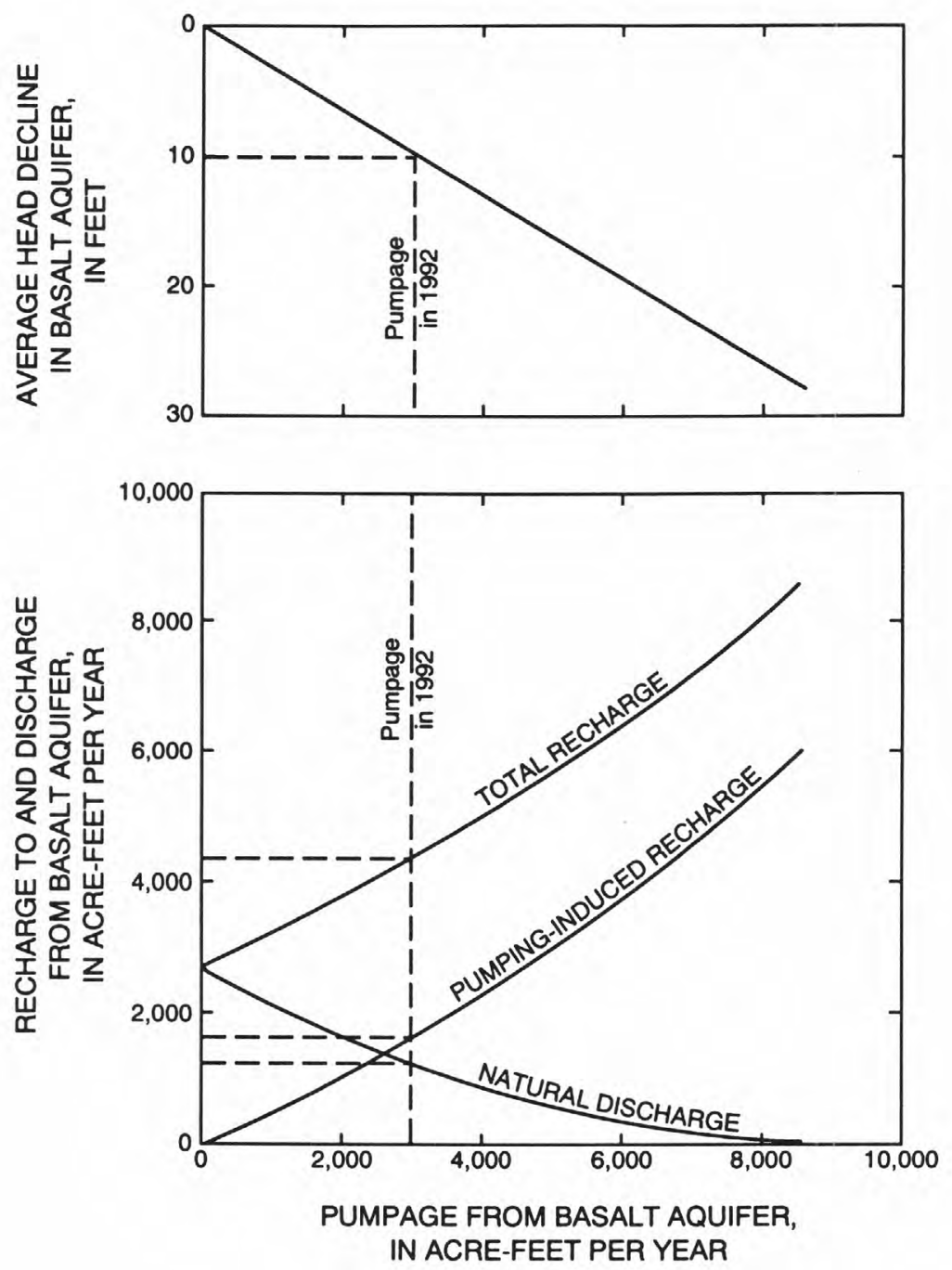

Figure 14. Relations among head decline, total recharge, pumping-induced recharge, natural discharge, and pumpage from basalt aquifer. Modified from Glancy (1986, fig. 12).

\section{WATER QUALITY}

\section{Surface-Water Quality}

The quality of surface water in the irrigation distribution system does not change greatly below Lahontan Dam until drain water enters the canal system (Rollins, 1965, p. 8). The dissolved-solids concentration of water leaving Lahontan Reservoir ranges from 150 to $500 \mathrm{mg} / \mathrm{L}$, generally increasing during lower flows and decreasing during higher flows (Lico, 1992, p. 16; Rollins, 1965, p. 10). Rollins (1965, p. 9) reported no measurable increase in dissolved-solids concentrations in the S-Line Canal as far as 5 mi east of Fallon, and only small increases in dissolved solids in the L-Line Canal until downstream from U.S. Route 95 . Rollins $(1965$, p. 10) also noted that water in drains near the center of irrigated lands was only slightly higher in dissolvedsolids concentration than in canals. However, a rapid increase in dissolved-solids concentration was noted in drains nearer to the Carson Lake, Stillwater WMA, and Carson Sink areas. More recent work by Sertic and others (1988, p. 47) shows a similar distribution of dissolved solids in the L-Line Canal during 1986. Hoffman and others (1990, p. 29) note about a ninefold increase in dissolved solids from Lahontan Reservoir to the Stillwater WMA.

The quality of water in drains near the groundwater discharge areas of the Carson Sink, Stillwater WMA, and Carson Lake is generally poor. Tabaei (1991, p. 46) suggests that the water quality of the nearby shallow aquifer has an effect on the quality of drain water. Hoffman (in press) suggests that deeper 
drains generally intercept a greater proportion of shallow ground water and have higher dissolvedsolids concentration than shallower drains. Newly installed drains are noted to have poor water quality (Bureau of Reclamation, 1987c, p. 19; Rollins, 1965, p. 8; and CH2M Hill, 1989, p. 4 -35). The authors of these reports speculate that water quality will improve over time as irrigation leaches salts from soils and drives poor-quality ground water toward drains.

The Bureau of Reclamation (1987c, fig. 5) reports that the dissolved-solids concentration in drain water on the Fallon Indian Reservation ranges from about 500 to $800 \mathrm{mg} / \mathrm{L}$ in the Paiute Drain and from about $8,000 \mathrm{mg} / \mathrm{L}$ to $16,000 \mathrm{mg} / \mathrm{L}$ in the TJ Drain. Lico (1992, p. 14) reports that drain water entering Stillwater WMA contained from 300 to $120,000 \mathrm{mg} / \mathrm{L}$ dissolved solids and that concentrations of arsenic, boron, and uranium commonly exceeded Nevada drinking-water standards or criteria for agricultural use and beneficial use by wildlife. Hoffman and others (1990, p. 36-37) report selenium concentrations in surface water near Stillwater WMA were below the detection limit; however, the Bureau of Reclamation (1987c, p. 2) report concentrations as high as $24 \mu \mathrm{g} / \mathrm{L}$ near the Fallon Indian Reservation. Dissolved mercury in surface water ranged from less than 0.1 to 1.1 $\mu \mathrm{g} / \mathrm{L}$ near Stillwater WMA (Hoffman and others, 1990, p. 36). Rollins (1965, p. 9) reports a maximum dissolved-solids concentration of $5,000 \mathrm{mg} / \mathrm{L}$ in the Carson River upstream from the Carson Sink. Rowe and others (1991, p. 96-97) report maximum dissolved-solids concentrations of 2,000 to 3,000 mg/L for drains entering Carson Lake.

The quality of water flowing in drains fluctuates seasonally. Rollins (1965, p. 10) notes that the concentration of dissolved solids was low during irrigation months, increasing sharply at the end of irrigation, and continuing to increase until the start of irrigation in the following spring. Similar seasonal fluctuations along with large daily fluctuations in dissolved-solids concentrations have been measured more recently by Rowe and others (1991, p. 16), Lico (1992, p. 15), and Tokunaga and others (1990). Drain flow during the irrigation season contains water from operational spills, irrigation return flow, and groundwater seepage. During the non-irrigation season, ground-water seepage supplies drain flow (Hoffman, in press). Ground water near the discharge areas of the basin is generally high in dissolved solids, increasing the dissolved-solids concentration of drain water during the non-irrigation season. Lico (1992, p. 18) estimates that ground water contributes about 30 percent of the dissolved-solids load in the TJ Drain.
Rollins (1965, p. 14) also noted that during a period of three drought years, dissolved-solids concentration increased markedly after the end of irrigation. He suggested that decreasing drainage flow by changing water use and Project efficiency could produce similar decreases in the water quality in drain flows leaving irrigated lands. Given the large daily fluctuations in dissolved solids noted in drain flow, continuous records at the same location could have determined whether similar increases in dissolved solids took place during the most recent drought. These data do not exist. Continued water-quality monitoring of drain flow would increase the understanding of how quality might change with changes in water use.

The load of dissolved solids leaving irrigated lands of the Carson Division was estimated by ClydeCriddle-Woodward (1971, p. 27) to be about 1 ton/acre during 1966. Recent measurements by Lico (1992, p. 19) showed that the load of dissolved solids from individual drains entering Stillwater WMA ranges from 3 to 50 ton/d with a total of about 122 ton/d in 1989. Hoffman (in press) showed that TJ and Hunter Drains supplied about 28 percent of the total load, although they supplied only about 5 percent of the flow volume.

\section{Ground-Water Quality}

Ground water in the Carson Desert varies greatly in composition and quality, ranging from a dilute calcium bicarbonate type in the western part of the basin and beneath irrigated lands, to a saline, sodium chloride type beneath areas of ground-water discharge near Carson Sink, Stillwater WMA, and Carson Lake (Michael S. Lico and Ralph L. Seiler, written commun., 1993).

Processes controlling ground-water quality in the Carson Desert have been ongoing for many thousands of years. Prior to the Newlands Project, large volumes of fresh water carrying sediments and dissolved solids from the Carson River annually flooded the western part of the basin. Before diversion of this water for irrigation, most surface-water flow was restricted to the main natural channels of the Carson River. Some water was lost to seepage in the western part of the basin, but most probably flowed to the Carson Sink, Carson Lake, and Stillwater areas and was lost to evaporation, leaving behind the dissolved solids. Water lost to seepage was discharged by transpiration and evaporation, resulting in an accumulation of dissolved solids in the soil profile and in the 
shallow aquifer. The distribution of sulfate, chloride, and alkalinity in the shallow aquifer under these conditions was documented by Stabler (1904).

Stabler (1904) documented the distribution of chloride (an indirect measure of the dissolved-solids concentration) in the shallow aquifer. He shows that, in the western part of the basin, near the center of the basin, and along channels of the Carson River, shallow ground water contained less than $1,000 \mathrm{mg} / \mathrm{L}$ of chloride. Between the river channels 5 to $6 \mathrm{mi}$ downgradient from Fallon, concentrations increased to more than $5,000 \mathrm{mg} / \mathrm{L}$ and increased to more than $10,000 \mathrm{mg} / \mathrm{L}$ near Carson Lake, more than $25,000 \mathrm{mg} / \mathrm{L}$ near Stillwater WMA, and more than $50,000 \mathrm{mg} / \mathrm{L}$ near the Carson Sink.

The natural processes controlling water quality were altered by irrigation for the Newlands Project. Today, under normal flow conditions, large volumes of water seep from distribution canals and irrigated fields on the western and central parts of the basin, driving subsurface ground-water flow toward drains installed for the Project and toward ground-water discharge areas in the northern, eastern, and southern parts of the basin.

However, the overall distribution of dissolved solids in ground water shown by Michael S. Lico and Ralph L. Seiler (written commun., 1993) is similar to that shown by Stabler (1904). Dissolved-solids concentrations in the shallow and intermediate aquifers are generally less than $1,000 \mathrm{mg} / \mathrm{L}$ within 5 to 6 mi downgradient from Fallon. More than 5 to $6 \mathrm{mi}$ downgradient from Fallon, concentrations increase to more than $1,000 \mathrm{mg} / \mathrm{L}$ and to more than $10,000 \mathrm{mg} / \mathrm{L}$ near discharge areas.

Water-quality characteristics distinguishing the shallow, intermediate, and deep aquifers have been described in previous sections. Welch and others (1989, figs. 35 a-d) described the general distribution of water quality in comparison with drinking-water standards for the State of Nevada. They show that concentrations of sulfate, chloride, fluoride, and dissolved solids exceed standards near the Upsal Hogback, Stillwater WMA, and Carson Lake areas; north, east, and south of a radius about 9 to $10 \mathrm{mi}$ from Fallon. Standards for arsenic and manganese are exceeded at sites throughout the Carson Desert and standards for iron are exceeded in areas generally west of U.S. Route 95 (Welch and others, 1989, fig. $35 \mathrm{e}-\mathrm{g}$ ). Proposed standards for uranium are exceeded most commonly in the shallow aquifer near groundwater discharge areas (Michael S. Lico and Ralph L. Seiler, written commun., 1993).

The rise in water levels from irrigation has caused previously unsaturated sediments to become saturated, changing the geochemical environment.
Processes associated with saturation of previously unsaturated sediments may be the cause of high concentrations of iron, manganese, and uranium in the Carson Desert (Michael S. Lico and Ralph L. Seiler, written commun., 1993).

The following sections describe water quality of the individual aquifers in greater detail.

\section{Shallow Aquifer}

Water quality changes greatly in the shallow aquifer from west to east. Dissolved-solids concentrations in the shallow aquifer range from less than $250 \mathrm{mg} / \mathrm{L}$ west of Fallon to more than $1,000 \mathrm{mg} / \mathrm{L}$ east of Fallon (Glancy, 1986, pl. 1), more than 40,000 $\mathrm{mg} / \mathrm{L}$ near Carson Lake (Michael S. Lico and Ralph L. Seiler, written commun., 1993), and more than $90,000 \mathrm{mg} / \mathrm{L}$ near Stillwater (Lico, 1992, p. 20).

Lico and Seiler (written commun., 1993) have shown that shallow ground water has a median $\mathrm{Ph}$ of 7.4 and substantiate Glancy's (1986) statement that ground water in the shallow aquifer is generally hard, contrasting with water in the intermediate aquifer that has a higher $\mathrm{pH}$ and is soft. Concentrations of dissolved arsenic generally exceed the drinking-water standard for the State of Nevada, and range from less than $50 \mu \mathrm{g} / \mathrm{L}$ to over $150 \mu \mathrm{g} / \mathrm{L}$ (Glancy, 1986, pl. 1).

Superimposed on these general trends, water quality within the shallow aquifer has been shown to vary dramatically over short distances both laterally and vertically. Glancy (1986, p. 50) attributes this variation to the uneven redistribution of naturally occurring salts in the soil profile that have been flushed laterally and vertically by irrigation. The complex lithology of the shallow aquifer has influenced the redistribution of these salts and produced the present distribution of water quality. Lico and Seiler (written commun., 1993) and Lico and others (1987) note that these abrupt changes are also, in part, controlled by proximity to canals, drains, irrigated fields, and by evapotranspiration.

Water quality of the shallow aquifer near areas of ground-water discharge is generally unacceptable for human consumption, commonly exceeding drinking water standards for the State of Nevada for some constituents. Near Stillwater WMA concentrations of dissolved solids, arsenic, and uranium exceeded drinking-water standards for the State of Nevada and criteria for agricultural use and beneficial use by wildlife: dissolved-solids concentrations ranged from about 13,000 to $70,000 \mathrm{mg} / \mathrm{L}$, arsenic concentrations ranged from 37 to $730 \mu \mathrm{g} / \mathrm{L}$, boron concentrations ranged from 22,000 to $120,000 \mu \mathrm{g} / \mathrm{L}$, uranium 
concentrations ranged from 16 to $950 \mu \mathrm{g} / \mathrm{L}$, and both mercury and selenium concentrations were below detection limits (Hoffman and others, 1990, p. 32-39). Near the Fallon Indian Reservation, dissolved-solids concentrations ranged from 23,000 to $109,000 \mathrm{mg} / \mathrm{L}$ (Tokunaga and others, 1990, p. 13); concentrations of arsenic, boron, and manganese, all exceeded standards for drinking water or recommended standards for agricultural crops (Tidball and others, 1991, p. 18). Near Carson Lake, concentrations of dissolved solids, sulfate, arsenic, boron, manganese, and uranium exceeded existing and proposed standards for drinking water and agricultural use. Measured concentrations were: dissolved solids, 25,000 to $49,000 \mathrm{mg} / \mathrm{L}$; sulfate, 5,600 mg/L; arsenic, $61 \mu \mathrm{g} / \mathrm{L}$; boron, $22,000 \mu \mathrm{g} / \mathrm{L}$; manganese, $1,500 \mu \mathrm{g} / \mathrm{L}$; and uranium, $310 \mu \mathrm{g} / \mathrm{L}$ (Hoffman and others, 1990, p. 116; Michael S. Lico and Ralph L. Seiler, written commun., 1993).

\section{Intermediate and Deep Aquifers}

Ground water in the intermediate aquifer is generally of acceptable quality for human consumption beneath inhabited areas near Fallon. The area where water quality is acceptable extends at least 12 mi west-northwest of Fallon and at least 10 mi northnortheast of Fallon along the Carson River, but perhaps only about $5 \mathrm{mi}$ to the southeast of Fallon (Glancy, 1986, p. 54). Within this area, the concentration of dissolved solids ranges from about 100 up to $1,000 \mathrm{mg} / \mathrm{L}$. In areas distant from Fallon, dissolved-solids concentrations are about $6,000 \mathrm{mg} / \mathrm{L}$ near Soda Lake, from 1,000 to about $5,000 \mathrm{mg} / \mathrm{L}$ near Upsal Hogback, from 4,000 to $8,000 \mathrm{mg} / \mathrm{L}$ near Stillwater WMA, and about $1,000 \mathrm{mg} / \mathrm{L} 2 \mathrm{mi}$ north of Carson Lake (Michael S. Lico and Ralph L. Seiler, written commun., 1993). No samples from the intermediate aquifer directly beneath Carson Lake have been analyzed.

As discussed previously, water in the intermediate aquifer is generally soft except west of Soda Lake. The $\mathrm{pH}$ of the intermediate aquifer is higher than that of the shallow aquifer, with a median value of 9.1 near Fallon (Michael S. Lico and Ralph L. Seiler, written commun., 1993). Concentrations of dissolved arsenic are generally less than $25 \mu \mathrm{g} / \mathrm{L}$ west of Fallon, increasing to more than $150 \mu \mathrm{g} / \mathrm{L}$ beneath and southeast of Fallon, and range from 2 to $1,400 \mu \mathrm{g} / \mathrm{L}$ near Stillwater WMA. (Glancy, 1986, pl. 2; Rowe and others, 1991, p. 190). State of Nevada drinking-water standards for manganese are exceeded at several locations near and west of Fallon, and standards for dissolved solids and chloride are exceeded near Upsal Hogback, Stillwater WMA, and Carson Lake (Michael S. Lico and Ralph L. Seiler, written commun., 1993).

Little is known about the quality of water in the deep aquifer. Glancy (1986, p. 21) infers that it is probably mostly saline, based on its electrical resistivity near the basalt aquifer. He further states that dissolved-solids concentrations are probably greater than $1,000 \mathrm{mg} / \mathrm{L}$ in all parts of the aquifer, may average about $5,000 \mathrm{mg} / \mathrm{L}$, and locally could greatly exceed $5,000 \mathrm{mg} / \mathrm{L}$.

\section{Basalt Aquifer}

Ground-water quality in the basalt aquifer is distinctively different from the sedimentary aquifers and its characteristics vary over a much narrower range. It is a sodium bicarbonate chloride water with concentrations of dissolved solids ranging from about 300 to almost $700 \mathrm{mg} / \mathrm{L}$. It has a median $\mathrm{pH}$ of 9.3 , and is uniformly soft with a hardness from 3 to 11 $\mathrm{mg} / \mathrm{L}$ (Glancy, 1986, table 5). Both of these characteristics are similar to those in the intermediate aquifer. Arsenic concentrations exceed drinking-water standards for the State of Nevada and range from about 70 to over $140 \mu \mathrm{g} / \mathrm{L}$.

Glancy (1986, p. 20) noted that concentrations of dissolved solids, sodium, alkalinity, chloride, and boron increase from the southwest to the northeast in the basalt aquifer. Glancy $(1986$, p. 20$)$ used this as evidence for flow in that direction, as also suggested by water-level data.

Glancy (1986) suggests that ground water in the basalt aquifer represents a blend of fresh and saline water, possibly caused by mixing of saline water from the deep aquifer and fresh water from the intermediate aquifer. If the salinity of the deep aquifer ranges from 1,500 to $10,000 \mathrm{mg} / \mathrm{L}$, ground water in the basalt aquifer could represent a blend of 73 to 96 percent water from the intermediate aquifer and 27 to 4 percent water from the deep aquifer, respectively (Glancy, 1986, p. 21).

Data from 1962-92, which will be discussed later, suggest that chloride and arsenic concentrations in the basalt aquifer are increasing near areas of pumping. The source of chloride and arsenic is assumed to be inflow of water from the surrounding aquifers.

Existing wells in the basalt aquifer and in nearby sedimentary aquifers extend to only 500 to $600 \mathrm{ft}$ below land surface and data on water quality deeper in the aquifer do not exist. Continued use of the basalt aquifer for public supply could be limited if nonpotable water is present at depth within the aquifer. Water-quality data for depths greater than 
$500 \mathrm{ft}$ in and near the basalt aquifer would determine the amount of potable water available in the basalt aquifer and refine the understanding of recharge mechanisms to the basalt aquifer.

\section{Geothermal Aquifers}

Dissolved-solids concentration in geothermal water near the Soda Lake/Upsal Hogback area ranges from 4,000 to $6,000 \mathrm{mg} / \mathrm{L}$ (Olmsted and others, 1984, p. 143). In the Stillwater area, geothermal water is more dilute than ground water in the shallow and intermediate aquifers, having an average dissolvedsolids concentration of about $4,000 \mathrm{mg} / \mathrm{L}$ (Morgan, 1982 , p. 53). In both areas, geothermal water is distinguished by higher concentrations of silica and, at some sites, fluoride when compared with nongeothermal water (Olmsted and others, 1984, table 17; Morgan, 1982, table 7; Michael S. Lico and Ralph L. Seiler, written commun., 1993).

\section{Variation in Quality}

In this section, variations in ground-water quality are statistically analyzed to (1) determine if irrigation has measurably affected ground-water quality, (2) evaluate the existing data set for its usefulness in determining the potential effects of reduced irrigation on ground-water quality, and if possible, (3) estimate the potential effects of reduced irrigation on groundwater quality. Presumably, changes in the quantity of water applied for irrigation would affect water quality in the shallow aquifers to a greater degree and more quickly than water in the deeper aquifers. Because water in the shallow aquifer system is the primary source of recharge to the deeper aquifers, any changes in the shallow ground-water quality may lead to changes in the other aquifers.

To determine the effects of irrigation, the basin was divided into four "hydrologic zones" that are thought to have similar dominant processes controlling ground-water flow and quality. In and near irrigated lands, the shallow ground-water flow system is thought to be dominated by the process of downward and lateral flushing by fresh surface water. Areas of ground-water discharge are thought to have dominantly upward ground-water flow, and processes controlling water quality are thought to be dominated by evaporative concentration. Upgradient from ground-water discharge areas and away from irrigated lands, ground-water flow is thought to be dominantly lateral, although the water quality can nonetheless be affected by evapotranspiration.
The four hydrologic zones are (1) irrigated areas having dominantly lateral ground-water flow (termed lateral-flow/irrigated areas), (2) non-irrigated areas having dominantly lateral flow (lateral-flow/nonirrigated areas), (3) irrigated areas where groundwater discharge dominates (discharge/irrigated areas), and (4) non-irrigated areas where discharge dominates (discharge/non-irrigated areas). The irrigated and non-irrigated areas, and overlapping lateral-flow and discharge areas, are shown in figure 15. Because data on vertical gradients are sparse, marshlands depicted on USGS 1:100,000-scale Fallon and Carson Sink quadrangle maps were used to delineate the groundwater discharge areas. The irrigated areas shown in figure 15 are generalized from digital data obtained from the Bureau of Reclamation (fig. 1), and include small, isolated tracts that are not irrigated but are surrounded by irrigated lands.

Existing water-quality data for wells in each zone were statistically analyzed to determine if significant differences (as defined in following section) in ground-water quality were discernible. Also analyzed were water-quality differences: for depth zones within the shallow aquifer; between the shallow and intermediate aquifers; before and after large-scale Project irrigation began in the early 1900's; and in the basalt aquifer from the early 1960's to 1992 .

Three approaches that might yield useful information about the effects of irrigation on the shallow ground-water quality have been considered. First, shallow water quality within the four hydrologic zones is compared because differences in water quality between irrigated and non-irrigated areas may reflect the effects of irrigation. A second approach would be to compare water quality beneath irrigated land during a period of reduced irrigation-water deliveries with water quality during more typical periods. The number of multiple analyses from individual wells, however, is not sufficient for a statistical comparison using this approach. The third approach is a comparison of water quality in the shallow aquifer before and after widespread Project irrigation began, because the removal of irrigation water presumably would eventually lead to waterquality conditions similar to those present prior to widespread irrigation.

The data set used in this analysis is that stored in the USGS National Water Information System data base, largely assembled by the Carson Basin National Water-Quality Assessment (NAWQA) Program of the USGS (Welch and others, 1989; Whitney, in press). The data include samples analyzed by the USGS, the Nevada State Health Services Laboratory, 


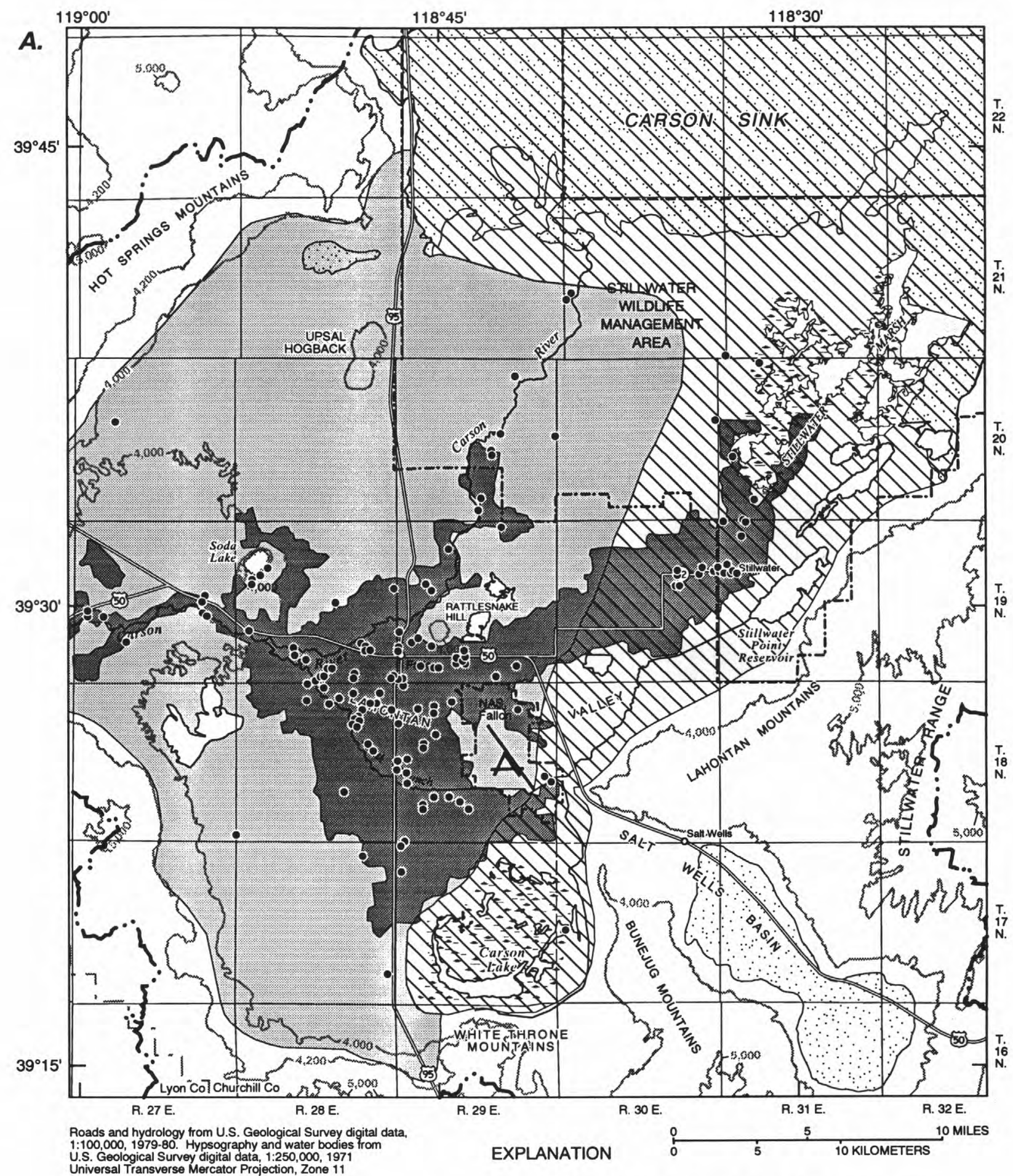

Universal Transverse Mercator Projection, Zone 11

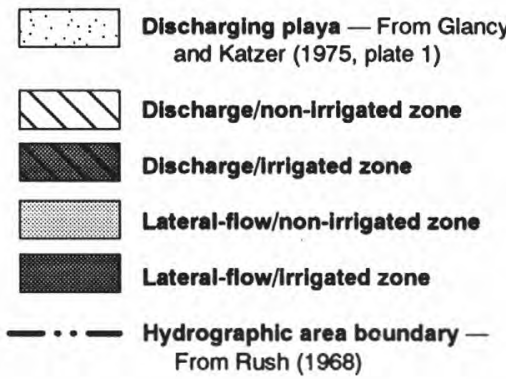
- 4,200 - Topographic contour - Shows altitude of land surface. Contour interval, 1,000 feet, with supplemental contour at 4,200 feet. Datum is sea level

Sampled well and aquifer in which completed

- Shallow aquifer (fig. 15A) - From Stabler (1904)

O Shallow aquifer after about 1975 (fig. 15B) - From Welch and others (1989); Whitney (in press); and National Water Information System data base (U.S. Geological Survey, Carson City, Nev.)

$\Delta \quad$ Intermediate aquifer after about 1975 (fig. 15B) - From Welch and others (1989); Whitney (in press); and National Water Information System data base (U.S. Geological Survey, Carson City, Nev.)

Figure 15. Extent of four hydrologic zones and wells sampled $(\boldsymbol{A})$ in shallow aquifer before widespread irrigation began, and $(B)$ in shallow and intermediate aquifers after about 1975. 


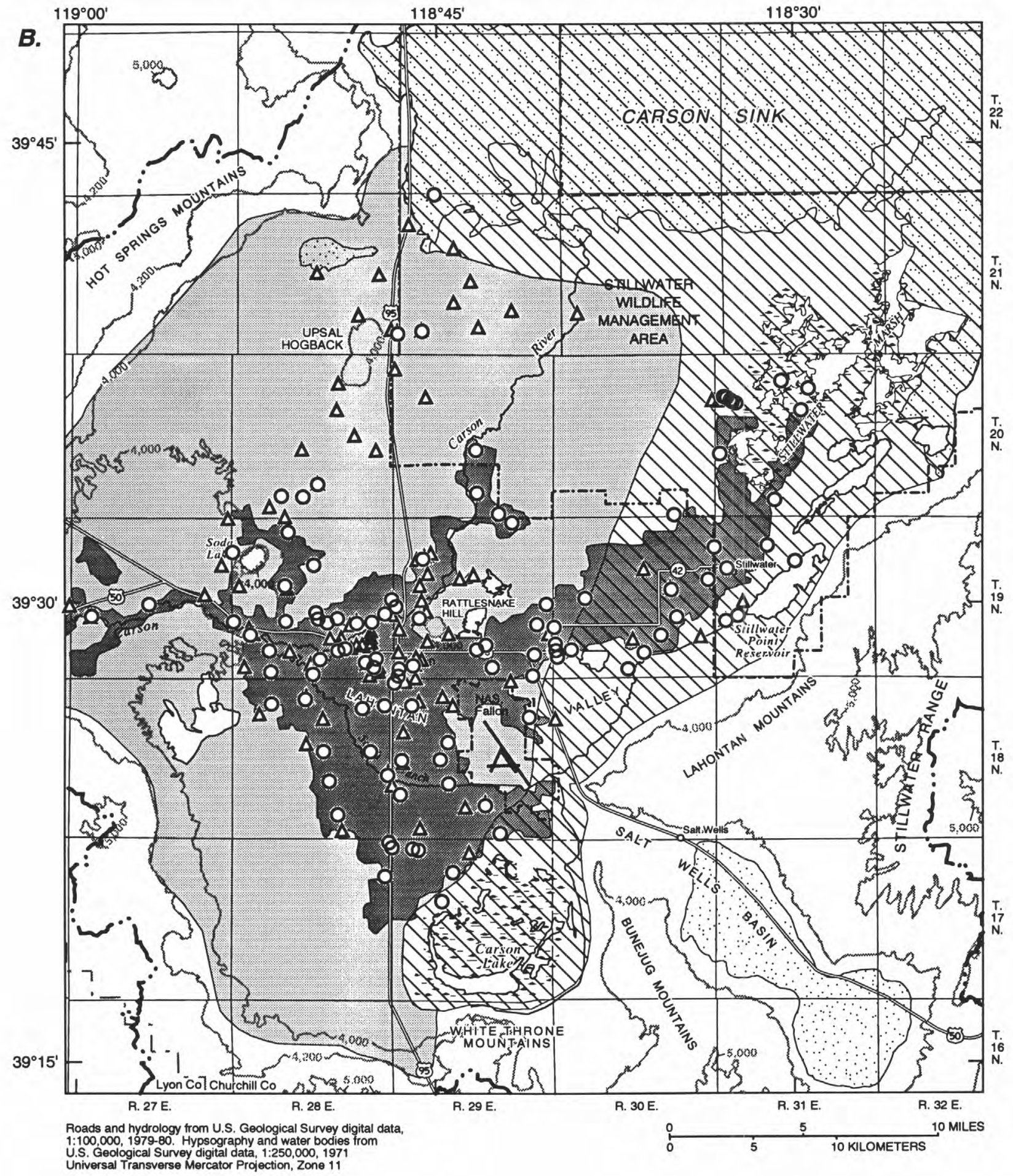

Figure 15.-Continued 
and private laboratories since about 1975 , and data collected and analyzed by Stabler (1904) prior to widespread Project irrigation.

Constituents selected for comparison are calcium, sodium, sulfate, chloride, arsenic, iron, and manganese, along with dissolved-solids content. Concentrations of these constituents and of dissolved solids can be used to delineate the effects of evapotranspiration and oxidation-reduction reactions on ground-water quality in the Carson Desert.

The major constituents-sodium, calcium, sulfate, and chloride - dominate the dissolved solids in the shallow aquifers and are largely affected by evaporative concentration (Michael S. Lico and Ralph L. Seiler, written commun, 1993). The other constituents discussed, which are present at much lower concentrations, are included because they are important in relation to Nevada drinking-water standards and are in solution primarily as a result of oxidationreduction reactions rather than evaporative concentration. Oxidation-reduction, or redox, reactions occur when one or more electrons move from one atom to another, and the reactions are affected by the amount of oxygen dissolved in ground water. The resulting change in oxidation state of some elements, such as iron and manganese, greatly affects their solubility in water. Iron and manganese are only sparingly soluble in water containing oxygen, whereas higher concentrations are common in water containing little or no oxygen. The presence of moderate to high concentrations of these two metals can be taken as evidence of chemically reduced conditions. Oxides of these metals, which are commonly present as coatings on aquifer sediments can act as a host for sorbed arsenic. The arsenic can be released to ground water either through dissolution of the oxides or by desorption (Welch and Lico, 1988).

\section{Display of Water-Quality Data and Statistical Analysis}

Boxplots are used to display the large number of data points included in this analysis. Boxplots, like those in figure 16 , display summary statistics regarding the distribution of reported concentrations (Tukey, 1977, p. 39-41). The statistical components are represented visually by features known as "boxes" and "whiskers," which can be described as follows. The box defines the spread of the middle 50 percent of the data (concentrations that lie between the 25 th and 75 th percentiles). The median value (the 50 th percentile) is shown by a horizontal line within the box. Vertical lines, which extend from the ends of the box to the maximum and minimum values, are called whiskers.
Nonparametric rather than parametric statistics are presented because water quality and other environmental data commonly do not, or cannot, be proved to fit some known and common numerical distribution. Additionally, extreme values are common in water-quality data. Extreme values can greatly affect estimates using parametric statistics. Nonparametric approaches use data ranks rather than actual values and do not require any assumptions regarding the numerical distribution of the data. Nonparametric approaches also avoid problems with extreme values that can greatly influence estimates of central tendency. Nonparametric tests are only slightly less efficient than parametric approaches when the data are normally distributed, and are more efficient when the data are not normally distributed (Hollander and Wolfe, 1973, p. 1).

For a comparison of medians, or central tendency, the Mann-Whitney $U$-test (Conover, 1980) is used. The Mann-Whitney test yields a test statistic called a "p-value." For the purposes of this report, the difference between median values is considered to be statistically significant only if the p-value is less than 0.1 . The confidence level is equal to one minus the p-value, expressed as a percentage. Accordingly, a $\mathrm{p}$-value of 0.1 is equal to a 90 -percent confidence level. Comparisons of groups of data are reported only when five or more values are present for each group.

The Mann-Whitney test allows comparison of medians (1) among the four hydrologic zones for the shallow and intermediate aquifers, (2) between the shallow and intermediate aquifers, and (3) for the shallow aquifer before and after widespread irrigation began in the early 1900's.

Results of the Mann-Whitney $U$-tests are displayed using schematic diagrams that are map and cross-sectional views of the hydrologic zones and aquifers delineated in the Carson Desert. In the mapview diagrams (such as fig. 17), arrows indicate constituents having median concentrations that are significantly higher in the zone where they are listed than in the zone from which the arrow originates. In the cross-sectional diagrams (fig. 22), comparisons are made between the shallow and intermediate aquifers, with constituents having significantly higher median concentrations in the aquifer where they are listed than in the other aquifer.

The data include multiple analyses for some wells. To avoid statistical bias toward such wells, only the most recent analyses are used in comparisons of the hydrologic zones. Similarly, in areas with closely spaced wells, the analytical results for only one of the wells are included in comparisons among aquifers and 

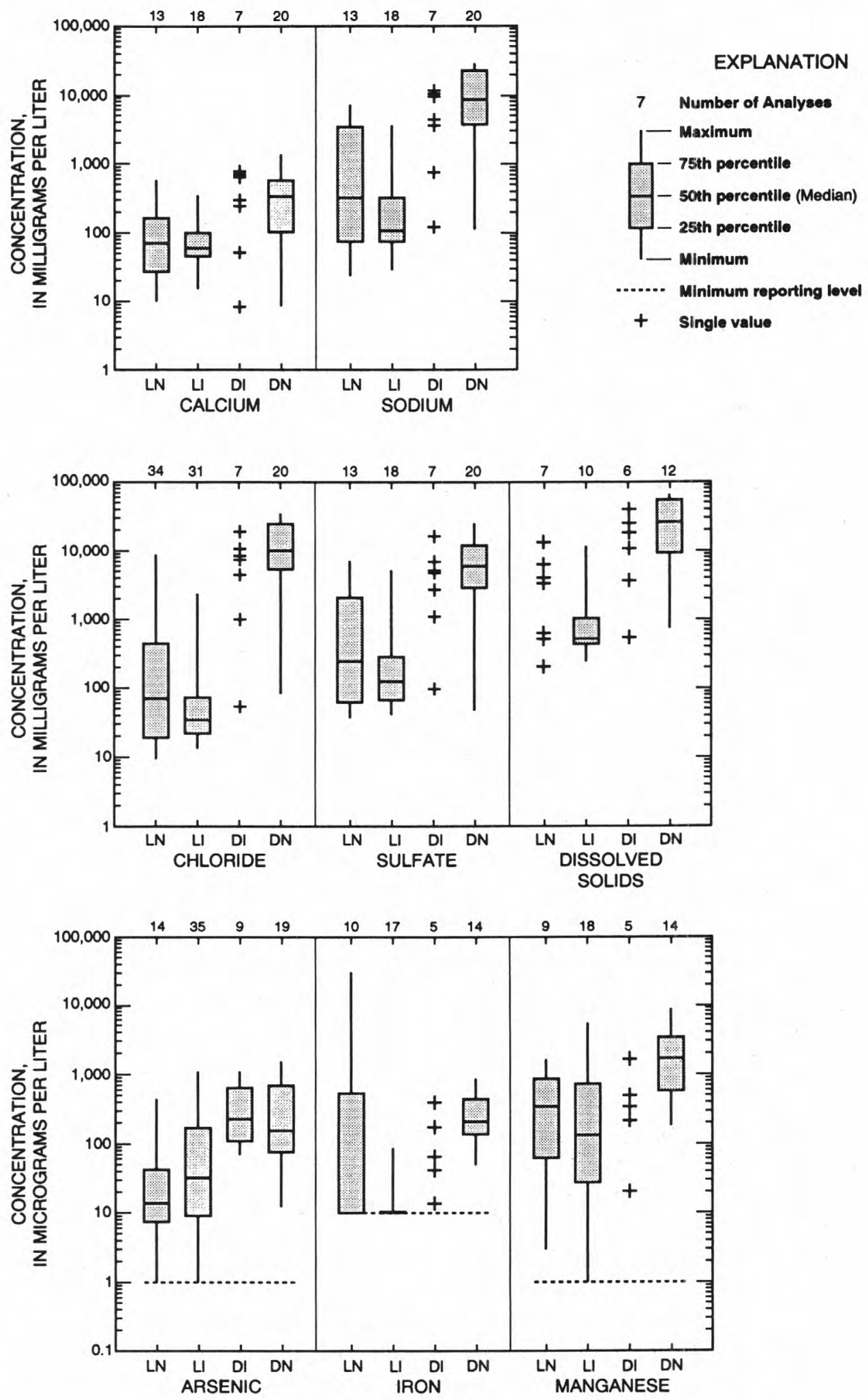

Figure 16. Summary statistics for concentrations of dissolved solids and constituents in ground water of shallow aquifer beneath four hydrologic zones after about 1975. Abbreviations: LI, lateral-flow/irrigated zone; LN, lateral-flow/nonirrigated zone; $\mathrm{DI}$, discharge/irrigated zone; DN, discharge/non-irrigated zone. 


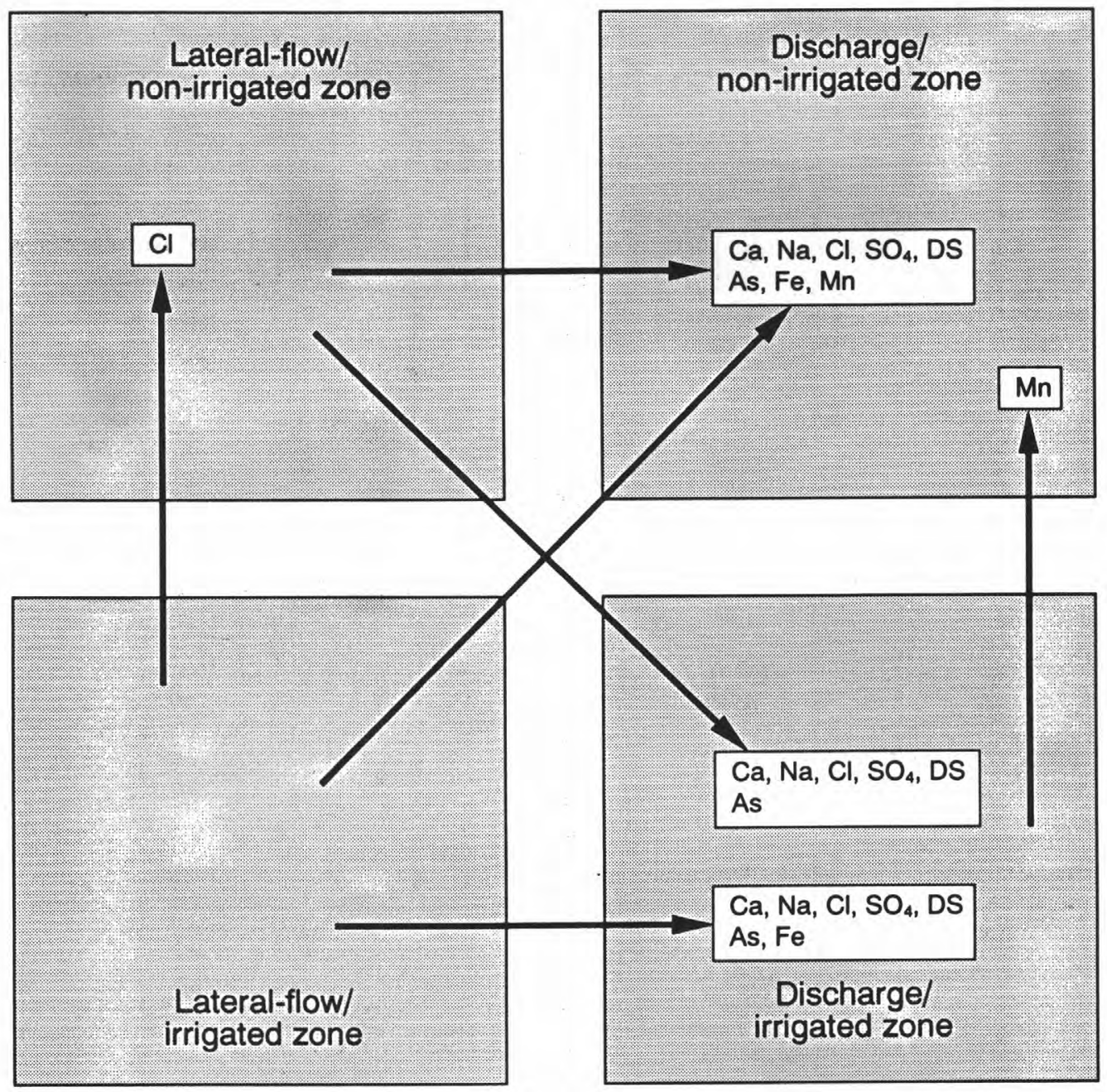

Figure 17. Differences in ground-water quality in shallow aquifer beneath four hydrologic zones after about 1975. Median concentrations of dissolved solids and indicated constituents are significantly higher statistically in labeled zones than in zones from which arrow points. As, arsenic; $\mathrm{Ca}$, calcium; $\mathrm{Cl}$, chloride; $\mathrm{DS}$, dissolved solids; $\mathrm{Fe}$, iron; $\mathrm{Mn}$, manganese; $\mathrm{Na}$, sodium; $\mathrm{SO}_{4}$, sulfate.

hydrologic zones. The most recent analysis since 1975 is used because analytical precision and accuracy generally have improved. Major-ion analyses were not used if the absolute value of the difference between the milliequivalents per liter of the cations and anions, divided by the sum of the two, is greater than 10 percent.

Statistical evaluation of water-quality data for time trends used the program ESTREND (Schertz and others, 1991), which produces a p-value for the Mann-Kendall test (Kendall, 1975). This method is a nonparametric approach. The data for the basalt aquifer include results of analyses for samples collected from about 1962 through 1992. For the few sites where more than one analysis is available for a single year, the median value was used.

\section{Comparison of Present-Day Water Quality in the Hydrologic Zones}

The comparison of ground-water quality in the shallow aquifer beneath the four hydrologic zones is based on the assumption that ground water in the uppermost $50 \mathrm{ft}$ beneath the irrigated land was recharged by irrigation. To test this assumption, comparisons were made of water quality from wells tapping different depth ranges within $50 \mathrm{ft}$ of the land surface beneath the lateral-flow/irrigated zone. The comparisons suggest that water from wells tapping the upper $20 \mathrm{ft}$ below land surface has median concentrations similar to water from wells tapping depths from 20 to $50 \mathrm{ft}$ below land surface. An exception is arsenic concentrations, which are significantly higher 
in the uppermost $20 \mathrm{ft}$. Thus, the water from land surface to depths of $50 \mathrm{ft}$ has probably had a similar genesis and is presumably a product of recharge by irrigation water.

Median concentrations of most of the selected constituents are generally higher in the discharge zones than in the lateral-flow zones (figs. 16 and 17). Higher concentrations are expected because water in the discharge zones is affected to a greater degree by evaporative concentration (Michael S. Lico and Ralph L. Seiler, written commun., 1993). Additionally, upflow from the intermediate aquifers beneath the discharge zones contributes water with higher dissolved-solids concentrations than the irrigation water. The higher arsenic, iron, and manganese concentrations are likely a result of low dissolvedoxygen concentrations, causing dissolution of iron and manganese oxides.

Of the selected constituents, only chloride has significantly different median concentrations within the two lateral-flow zones of the shallow aquifer, with higher medians in the non-irrigated areas (fig. 17). Otherwise, water quality in the lateral-flow/nonirrigated zone appears similar to that in the lateralflow/irrigated zone. This suggests that irrigation has lowered chloride concentrations in the irrigated zone, possibly due to dilution. If this conclusion is correct, then irrigation has had only a minor effect on the overall water quality in the shallow aquifer.

Among data for the two discharge zones, only manganese has significantly different median concentrations (fig. 17). However, only five analyses are available for the discharge/irrigated zone, making any conclusions based on this comparison tenuous. The higher manganese concentrations in the discharge/nonirrigated zone may reflect a greater influence of upflow from the intermediate aquifer that contains little or no oxygen. More samples obtained from the discharge/irrigated zone would provide a firm basis for this conclusion.

The conclusion that irrigation has had only a minor effect on water in the shallow aquifer could be complicated by differences between the two lateralflow zones. The lateral-flow/irrigated zone is generally closer to surface-water sources of recharge, and soils with extremely low permeabilities may have been unsuitable for crop production. Thus, recharge within the irrigated zone may be associated with more permeable deposits to a greater degree than within the non-irrigated zone.

To evaluate the possible associations of water quality with permeability, data for areas with high and low permeability in the Fallon Formation (pl. 3) were compared in all four hydrologic zones. The median arsenic concentration in wells located where less permeable sediments are exposed is higher than in wells located where more permeable sediments are exposed. No other selected constituent has statistically different median concentrations in the two groups of analyses.

Near-surface channel deposits mapped by Morrison (1964) also indicate the presence of sediments with relatively high permeabilities. Median concentrations of selected constituents in ground water less than $30 \mathrm{ft}$ below land surface were grouped by determining whether a well is underlain by a mapped channel deposit. The 30 -ft depth was arbitrarily chosen as an estimate of a reasonable limit for the thickness of channel deposits. In the lateralflow/irrigated zone, however, less than five sampled wells are at locations underlain by channel deposits. Additional samples obtained from channel deposits would provide a means to evaluate their effect on the distribution of water quality.

\section{Water Quality Before and After Widespread Project Irrigation Began}

A complicating factor in the comparison of water quality before and after widespread Project irrigation began is that the same wells were not sampled before and after the onset of irrigation (fig. 15). The statistical effect of the two sets of sample locations cannot be determined. Nonetheless, a few differences in the distribution of the sampled wells may be pertinent. First, a greater proportion of the pre-irrigation sites were near the Carson River in the lateral-flow zones. Because the dilute water of Carson River was a major source of recharge to the shallow aquifer prior to irrigation, the older data might be expected to represent samples with lower concentrations than the more recent data. Second, many of the wells sampled before Newlands Project irrigation in the discharge/irrigated zone are near the town of Stillwater (fig. 15A), compared with a more evenly distributed set of wells sampled in that zone after the onset of irrigation (fig. 15B). Third, at the time the Newlands Project began, about 1903, approximately 14,000 acres were already under cultivation (Lee and Clark, 1916, p. 670). Therefore, some of the water sampled by Stabler (1904) may have already been affected by irrigation. Samples collected prior to widespread irrigation were analyzed for sulfate, chloride, and dissolved solids (Stabler, 1904).

A comparison of median concentrations of sulfate, chloride, and dissolved solids prior to Project irrigation indicates differences between the four zones at that time (figs. 18 and 19). Among differences are 
higher sulfate and dissolved-solids concentrations in the lateral-flow/irrigated zone compared to the lateralflow/non-irrigated zone. In contrast, post-irrigation data are not significantly different, except for chloride (fig. 17). Higher concentrations prior to widespread irrigation imply that sulfate and dissolved solids in the lateral-flow zone decreased in response to irrigation practices (fig. 20A).

The median sulfate, chloride, and dissolvedsolids concentrations prior to widespread irrigation are greater in both discharge zones than in the two lateral-flow zones (fig. 19). Data collected after widespread irrigation began generally indicate the same relations.

The comparisons suggesting that sulfate has decreased since the onset of irrigation have the complicating factor that the sampling and analysis techniques reported by Stabler (1904) might not be directly comparable to those presently used. Of particular concern is that most samples used for evaluation of current conditions were filtered prior to analysis, whereas the pre-irrigation samples almost certainly were not. Unfiltered samples may produce greater values if samples contain suspended material.
Therefore, even if the analytical techniques produce comparable results, the earlier samples could contain material that would not pass through the filters currently being used.

On the basis of only six to seven samples (fig. 20B), median concentrations of sulfate, chloride, and dissolved solids in the shallow aquifer of the discharge/irrigated zone appear to have increased since the beginning of irrigation. As noted above, the clustering of pre-irrigation sample sites around the town of Stillwater makes this comparison problematic.

\section{Water Quality in the Shallow and Intermediate Aquifers}

Most of the measured constituents and dissolved solids have higher median concentrations in the shallow aquifer than in the intermediate aquifer (figs. 21 and 22). These higher concentrations are consistent with a greater influence of evapotranspiration in the shallow aquifer. One notable exception is that of iron in both lateral-flow zones, where the median concentrations are greater in the intermediate aquifer than in the shallow aquifer (figs. 21 and 22).

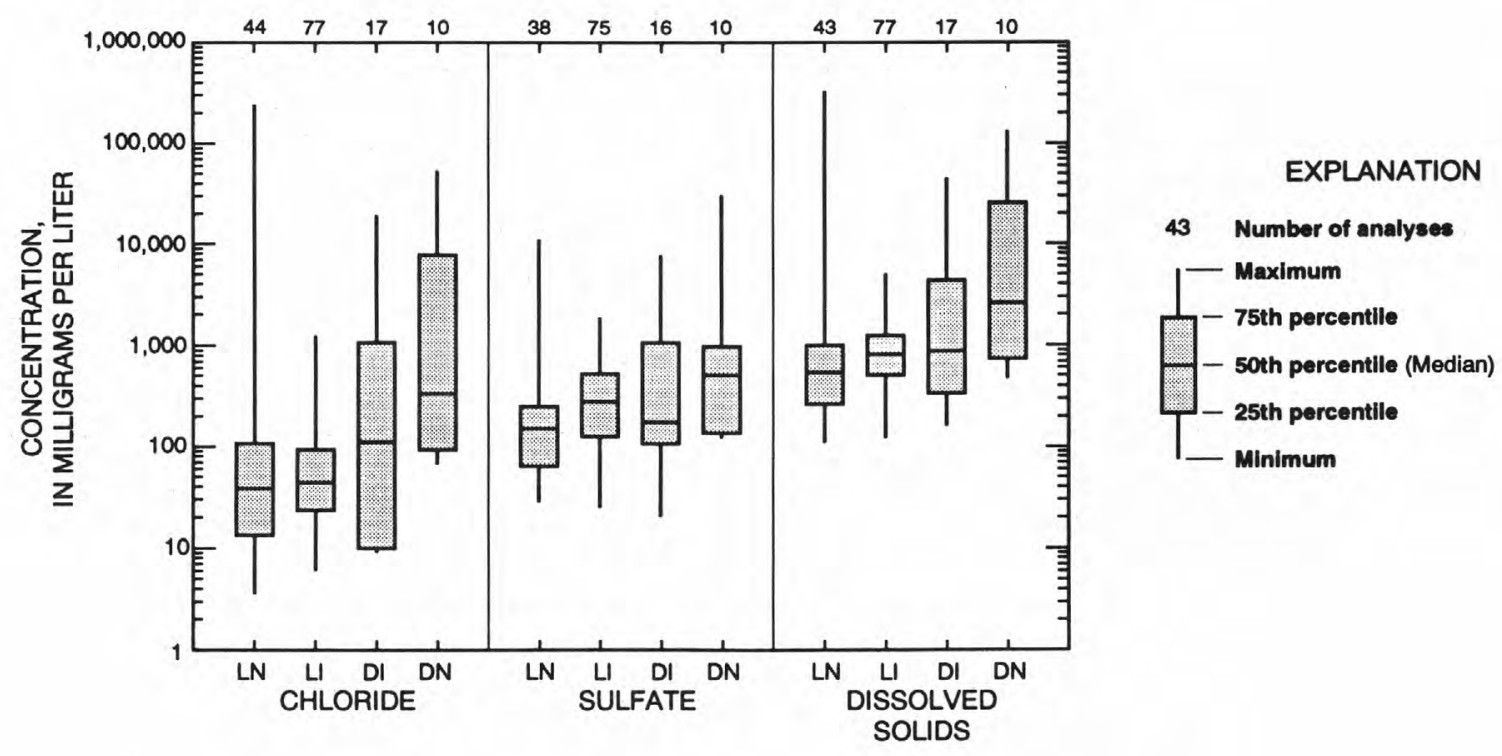

Figure 18. Summary statistics for concentrations of chloride, sulfate, and dissolved solids in ground water of shallow aquifer beneath four hydrologic zones before widespread irrigation began. Abbreviations: LI, lateralflow/irrigated zone; LN, lateral-flow/non-irrigated zone; DI, discharge/irrigated zone; DN, discharge/non-irrigated zone. 


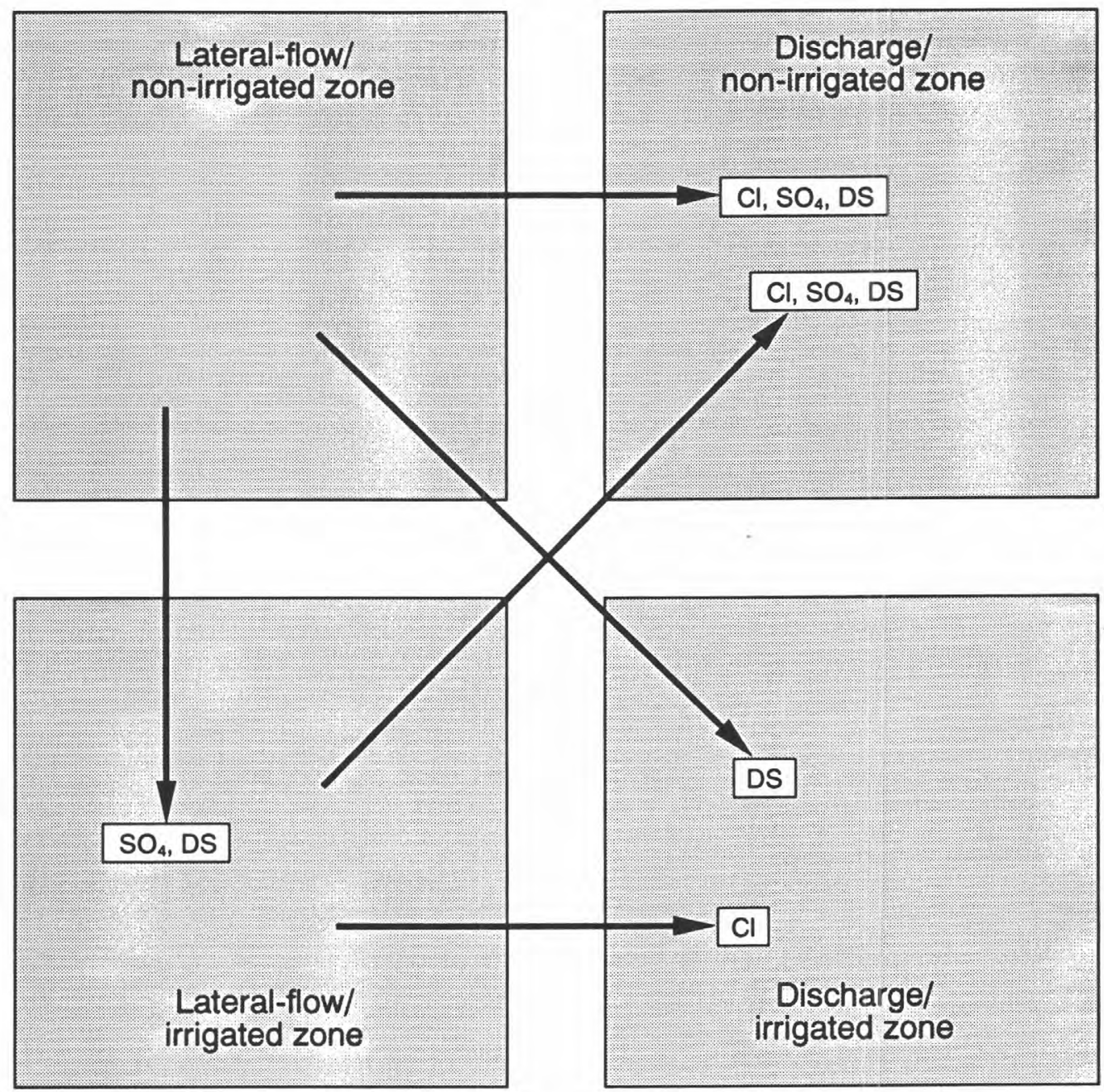

Figure 19. Differences in ground-water quality within shallow aquifer beneath four hydrologic zones before widespread irrigation began. Median concentrations of dissolved solids and indicated constituents are significantly higher statistically in labeled zones than in zones from which arrow points. $\mathrm{Cl}$, chloride; DS, dissolved solids; $\mathrm{SO}_{4}$, sulfate.

The higher iron concentrations imply low dissolvedoxygen concentrations (more reduced conditions) in the intermediate aquifer in these two zones. Generally higher concentrations of other constituents in the shallow aquifers than in the intermediate aquifers suggest recharge of the intermediate aquifers by relatively dilute surface water moving downward along preferential flow paths - either on the west side of the basin or through relict channel deposits near the center of the basin, rather than by diffuse downward flow from the shallow aquifer.

Median concentrations of sodium and chloride in the intermediate aquifer are greater in the discharge/non-irrigated zone than in either lateral-flow zone (fig. 23). Discharge-zone ground water probably has a greater residence time than water in the lateralflow zones resulting in higher dissolved-solids concentrations. Similarly, water in the lateral-flow/nonirrigated zone is farther away from the probable recharge areas than water in the lateral-flow/irrigated zone, which may contribute to the higher concentrations of calcium, sodium, chloride, and dissolved solids in the non-irrigated zone.

Among the three zones having more than five sampled sites in the intermediate aquifer, the lateralflow/irrigated zone has water with the highest median arsenic concentration (fig. 23). Additionally, the median iron concentration is higher in the 
A.

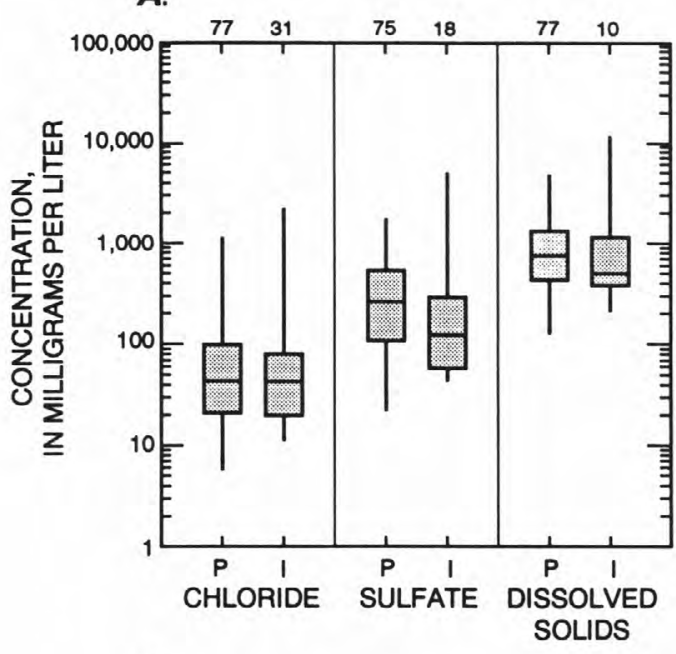

B.
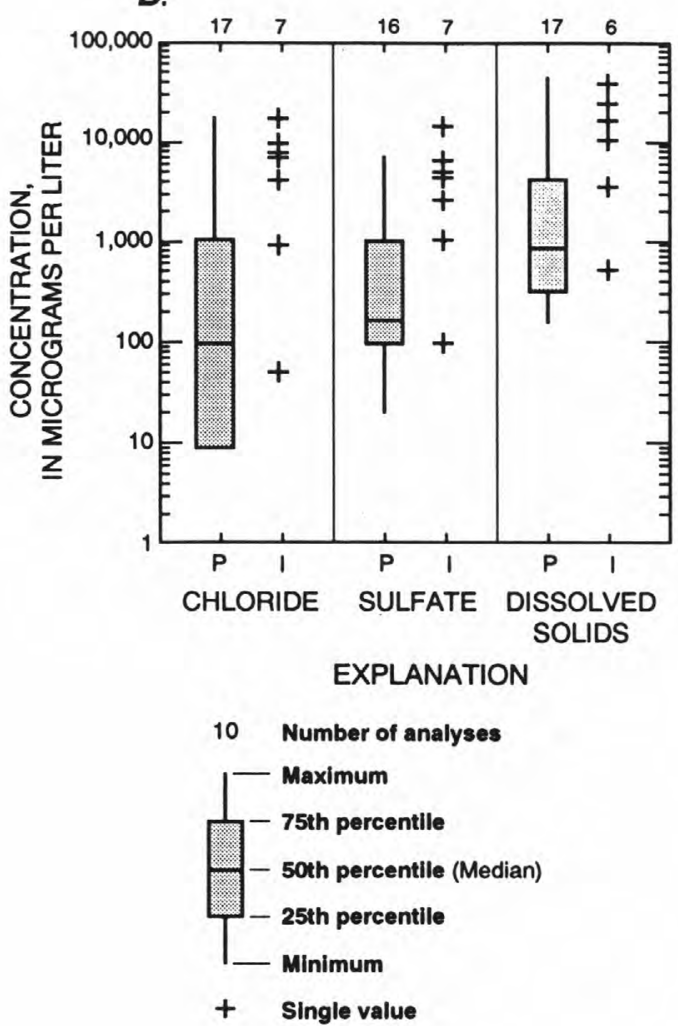

Figure 20. Summary statistics for concentrations of chloride, sulfate, and dissolved solids in ground water of shallow aquifer beneath $(A)$ lateral-flow/irrigated zone and $(B)$ discharge/irrigated zone before and after widespread irrigation began. Abbreviations: $\mathrm{P}$, preirrigation; I, during irrigation. lateral-flow/irrigated zone than in the lateral-flow/nonirrigated zone. The higher arsenic in the lateralflow/irrigated zone may be a result of release from iron oxides.

\section{Analysis of Time-Trend Data}

The only wells that have been repetitively sampled over a period greater than a few years are those completed in the basalt aquifer. Among these wells, three have chloride concentrations, determined by several different laboratories, that show a statistically significant increase between about 1962 and 1992 (fig. 24). Chloride concentrations at these three closely spaced wells (Navy wells 1-3, fig. 12) increased from about $90 \mathrm{mg} / \mathrm{L}$ in the early 1960's to about $110 \mathrm{mg} / \mathrm{L}$ in 1992 , a range greater than the analytical uncertainty. Taken together, the same general range in concentration, the proximity of these three wells, and the relatively low statistical p-values combine to strongly suggest that the increase truly reflects increasing chloride concentrations in the basalt aquifer.

The cause of the chloride increase in the vicinity of the Navy wells is not known. Considering the lengthy period of increase (about 30 years), the cause is unlikely to be the short-term decrease in delivered irrigation water during the drought years from 198892. A more likely cause is a decrease in the hydraulic head (fig. 13) which could in turn cause increased flow from adjacent aquifers in which water contains higher chloride concentrations. The Navy wells are more likely to be affected by flow from adjacent aquifers than other public-supply wells because they tap the basalt aquifer near its edge. Available data from surrounding wells in the intermediate aquifer show that water in most of the wells has chloride concentrations of less than $15 \mathrm{mg} / \mathrm{L}$. This suggests that the intermediate aquifer is not the source of chloride. Aquifers that underlie the basalt are a possible source of the chloride. Because the distribution of water quality at depths greater than about 600 $\mathrm{ft}$ within the basalt aquifer is not known, the chloride source could also be within the basalt aquifer itself.

Concentrations of calcium in water from the Navy wells may have decreased during the same period that chloride increased, although the statistical evidence is weak. At all three wells, the initially reported concentrations were $2.2 \mathrm{mg} / \mathrm{L}$. Since 1977 , nearly all calcium analyses indicate a concentration of $1.0 \mathrm{mg} / \mathrm{L}$ in all three wells. The cause of the calcium decrease may be related to the inflow of water from intermediate or deeper aquifers.

Reported arsenic concentrations in the Kennemetal well (fig. 12) near the west-central edge of the basalt aquifer were $95 \mu \mathrm{g} / \mathrm{L}$ in 1974 compared to $112 \mu \mathrm{g} / \mathrm{L}$ 

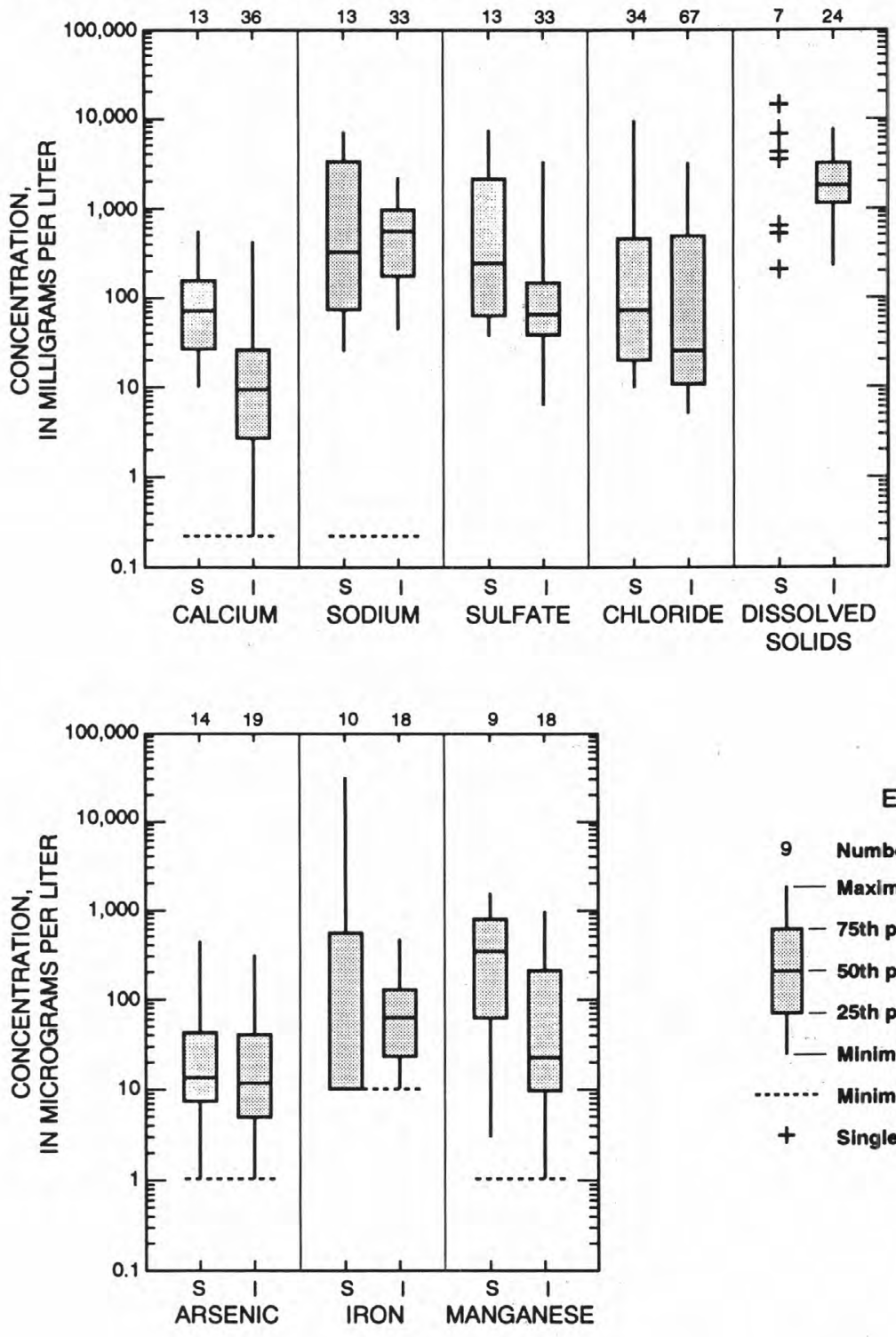

EXPLANATION

9 Number of analyses

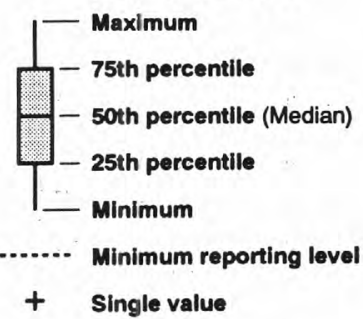

Figure 21. Summary statistics for concentrations of dissolved solids and constituents in ground water of shallow and intermediate aquifers beneath $(A)$ lateral-flow/non-irrigated zone, $(B)$ lateral-flow/irrigated zone, and $(C)$ discharge/non-irrigated zone after about 1975. Abbreviations: S, shallow aquifer; I, intermediate aquifer.

aquifer were $95 \mu \mathrm{g} / \mathrm{L}$ in 1974 compared to $112 \mu \mathrm{g} / \mathrm{L}$ in 1992. Arsenic concentrations for twelve samples collected from the Kennemetal well over this same period yield a p-value of about 0.04 . This p-value suggests that the increase is statistically significant. As for chloride in the water from the Navy wells, the cause of the difference is not known but may be the inflow of water into the basalt aquifer in response to pumping.

\section{Discussion of Statistical Comparisons}

The statistical comparisons of water quality in the four hydrologic zones and before and after Project irrigation began must be interpreted with caution because of the complicating factors discussed above. The separation into the four hydrologic zones may, in fact, be more useful as a guide for the design of future investigations than as definitive evidence of 
B. Lateral-flow/irrigated zone
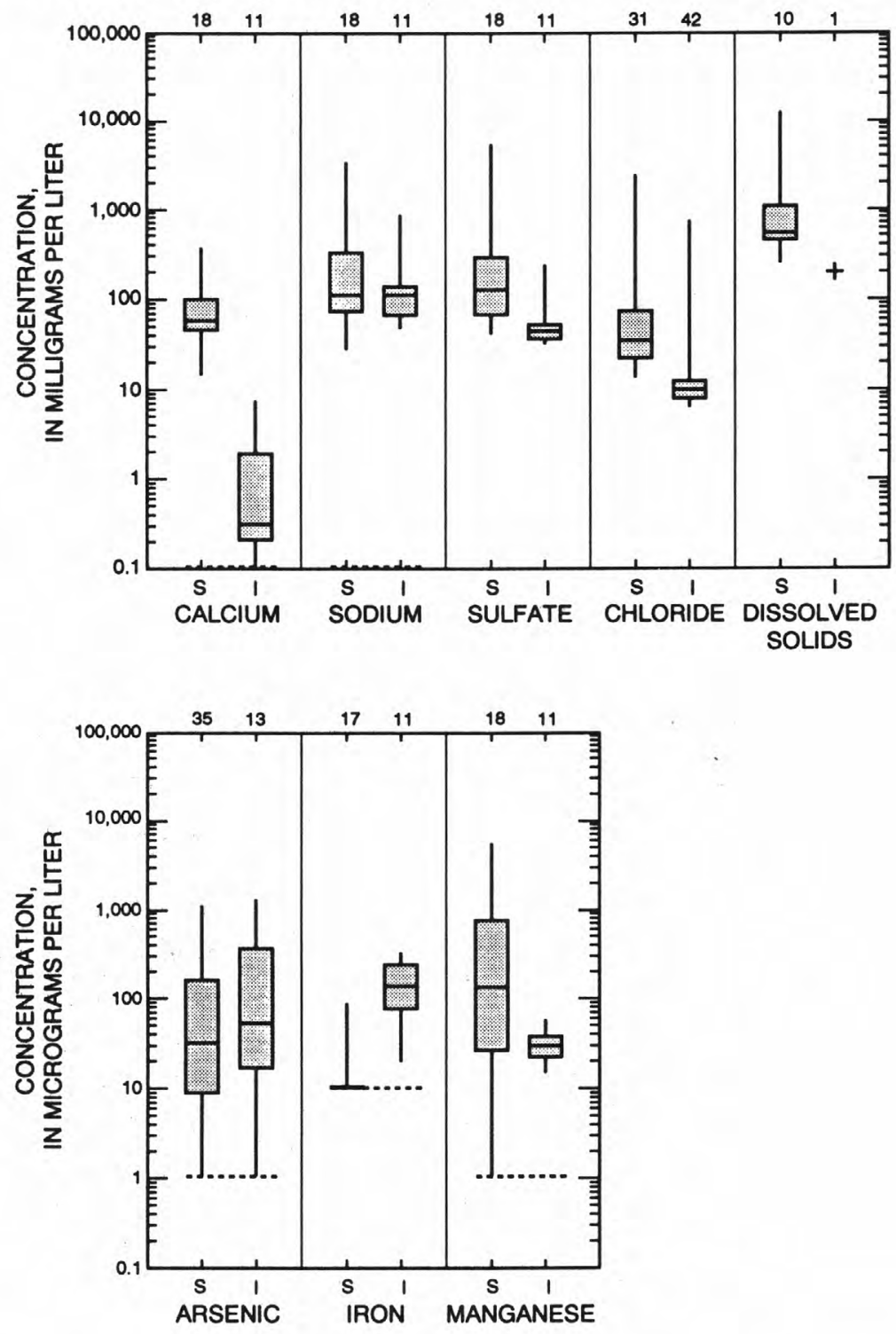

Figure 21.-Continued.

changes in water quality due to irrigation. Despite the limitations imposed by the availability of data, the variations in concentrations seem to be statistically important and hydrologically reasonable.

A reduction in irrigation could potentially increase or decrease concentrations of dissolved constituents in the shallow aquifer. Since widespread irrigation began, the relatively dilute irrigation water may have caused a decrease in the concentrations of dissolved constituents in the shallow aquifers through flushing or dilution of more saline water. Application of irrigation water also has raised the water table, which can increase rates of evapotranspiration and thereby increase concentrations. The available data do not provide a definitive indication of which process is more important, although the statistical evidence suggests that irrigation has led to lower concentrations of sulfate, chloride, and dissolved solids in the lateral-flow zone.

Concentrations of arsenic are higher in the upper $20 \mathrm{ft}$ of the shallow aquifer than from 20 to $50 \mathrm{ft}$ below land surface in the lateral-flow/irrigated zone, 
C. Discharge/non-irrgated zone
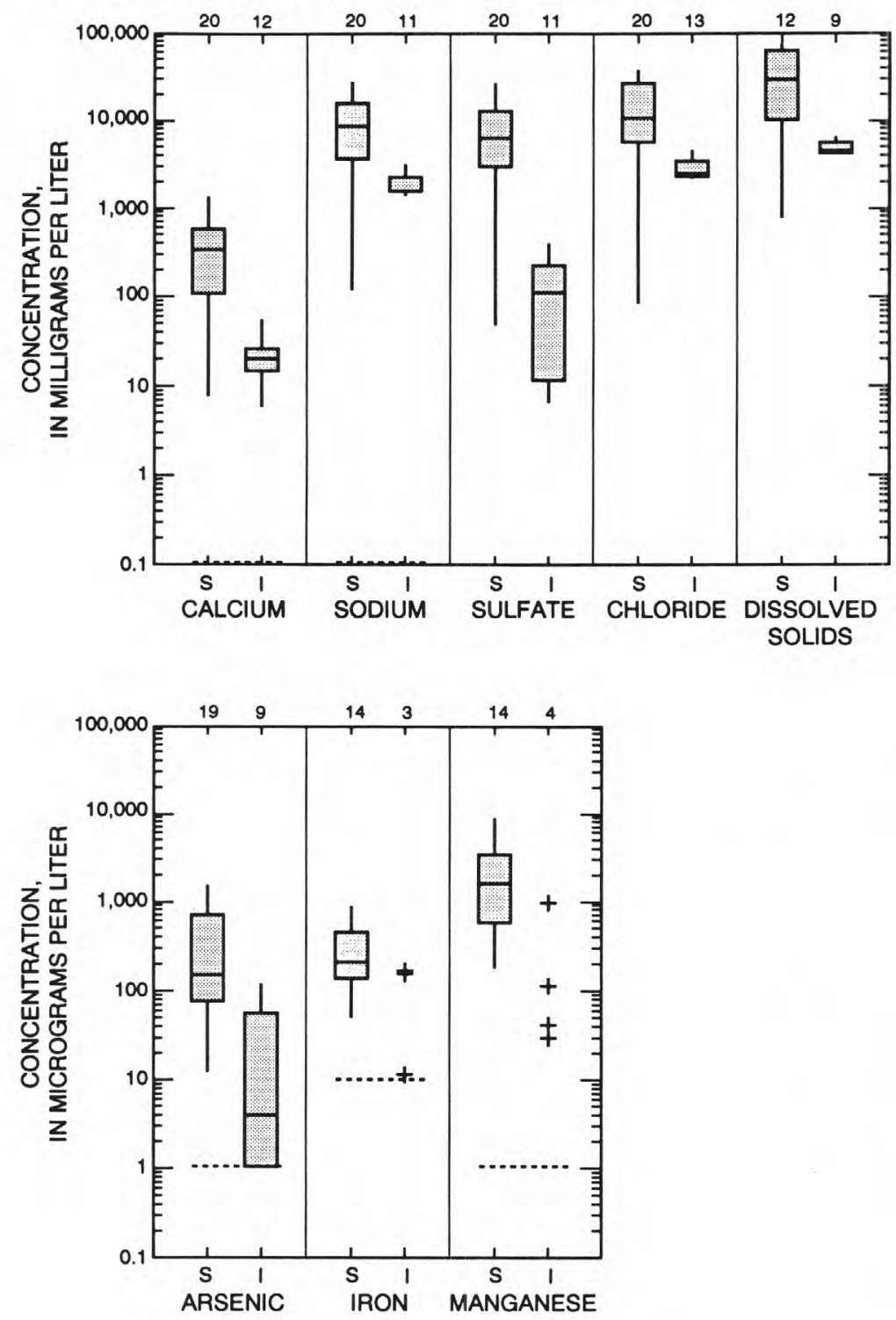

Figure 21.-Continued.

and are higher in less permeable deposits than permeable deposits. The statistical comparisons do not indicate that irrigation has affected median concentrations of arsenic, iron, and manganese in the shallow aquifer in the lateral-flow zones. These results appear to conflict with conclusions of other geochemical studies (Welch and Lico, 1988; and Lico and others, 1986). These studies concluded that these constituents are mobilized by water applied for irrigation.
The apparent conflict may be because the data sets used in these comparisons are not truly representative of ground water unaffected by irrigation. A direct comparison of water quality before and after the onset of irrigation cannot be made because of a lack of data for these trace constituents. Consequently, the effects of irrigation on arsenic, iron, and manganese concentrations cannot be addressed with certainty. 
Lateral-flow/

non-irrigated zone

non-irrigated zone

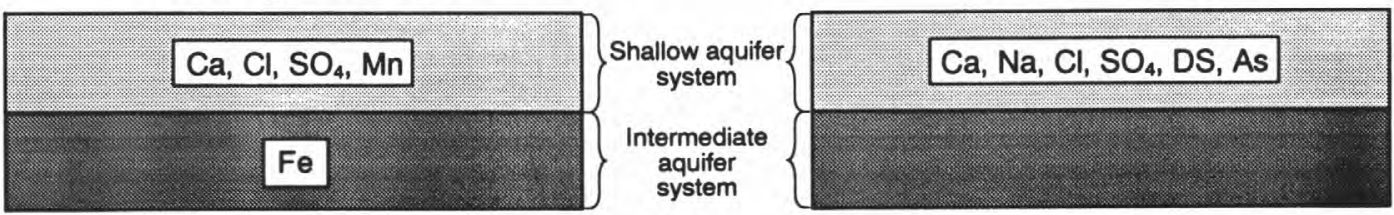

Lateral-flow/

irrigated zone

Discharge/

irrigated zone

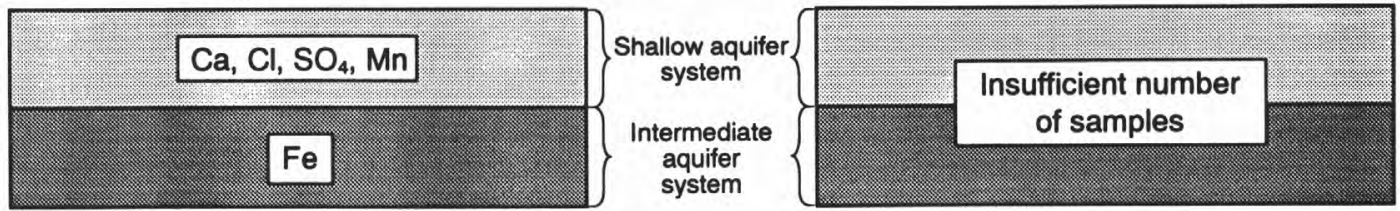

Figure 22. Differences in ground-water quality between shallow and intermediate aquifers beneath four hydrologic zones after about 1975. Within each cross section, median concentrations of dissolved solids and indicated constituents are significantly higher statistically in the aquifer system where they are listed than in the other aquifer. As, arsenic; $\mathrm{Ca}$, calcium; Cl, chloride; DS, dissolved solids; $\mathrm{Fe}$, iron; $\mathrm{Mn}$, manganese; $\mathrm{Na}$, sodium; $\mathrm{SO}_{4}$, sulfate.

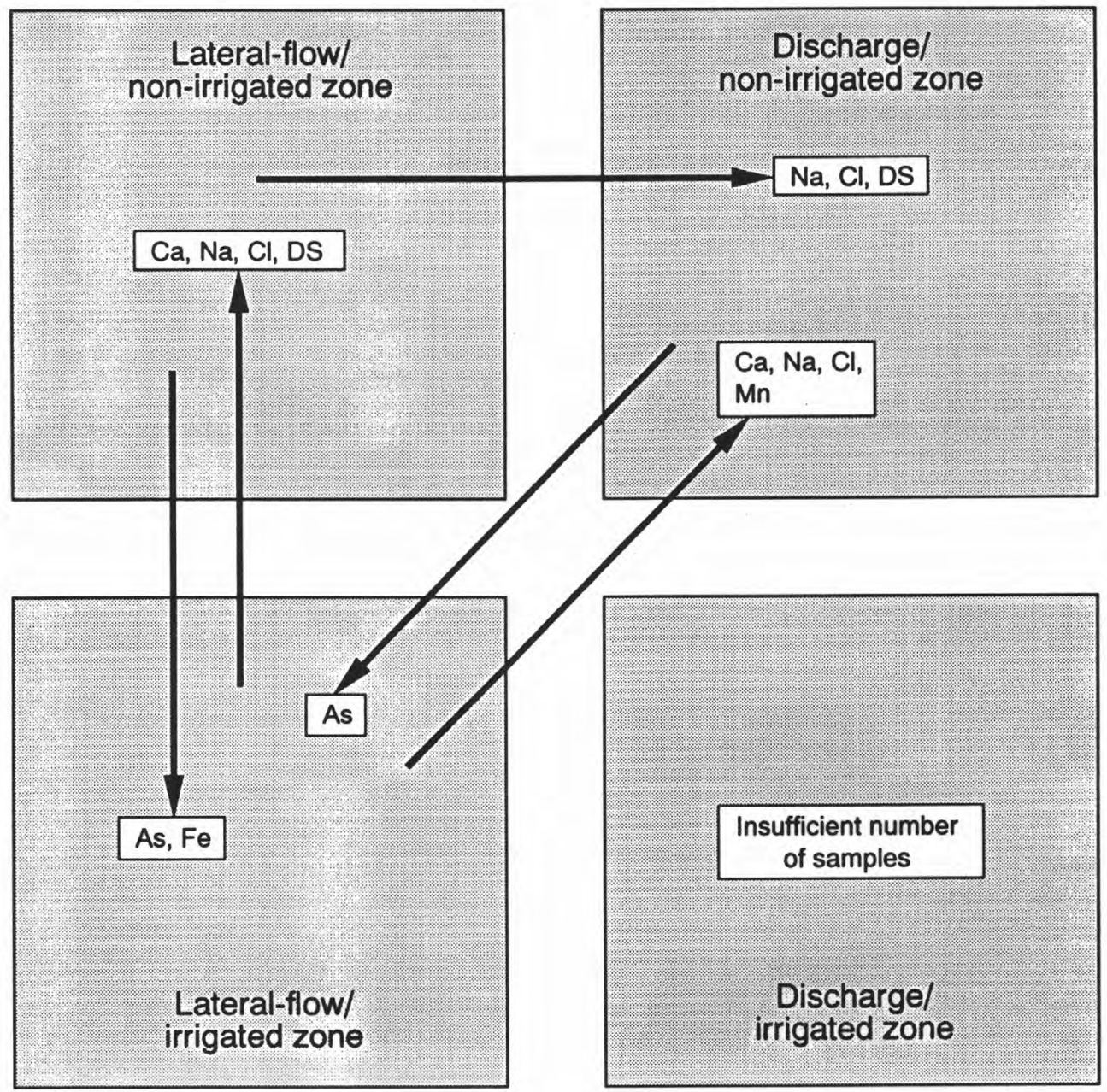

Figure 23. Differences in ground-water quality within intermediate aquifer beneath four hydrologic zones after about 1975 . Median concentrations of dissolved solids and indicated constituents are significantly higher statistically in zones where they are listed than in zones from which arrow points. As, arsenic; $\mathrm{Ca}$, calcium; $\mathrm{Cl}$, chloride; $\mathrm{DS}$, dissolved solids; $\mathrm{Fe}$, iron; $\mathrm{Mn}$, manganese; $\mathrm{Na}$, sodium. 

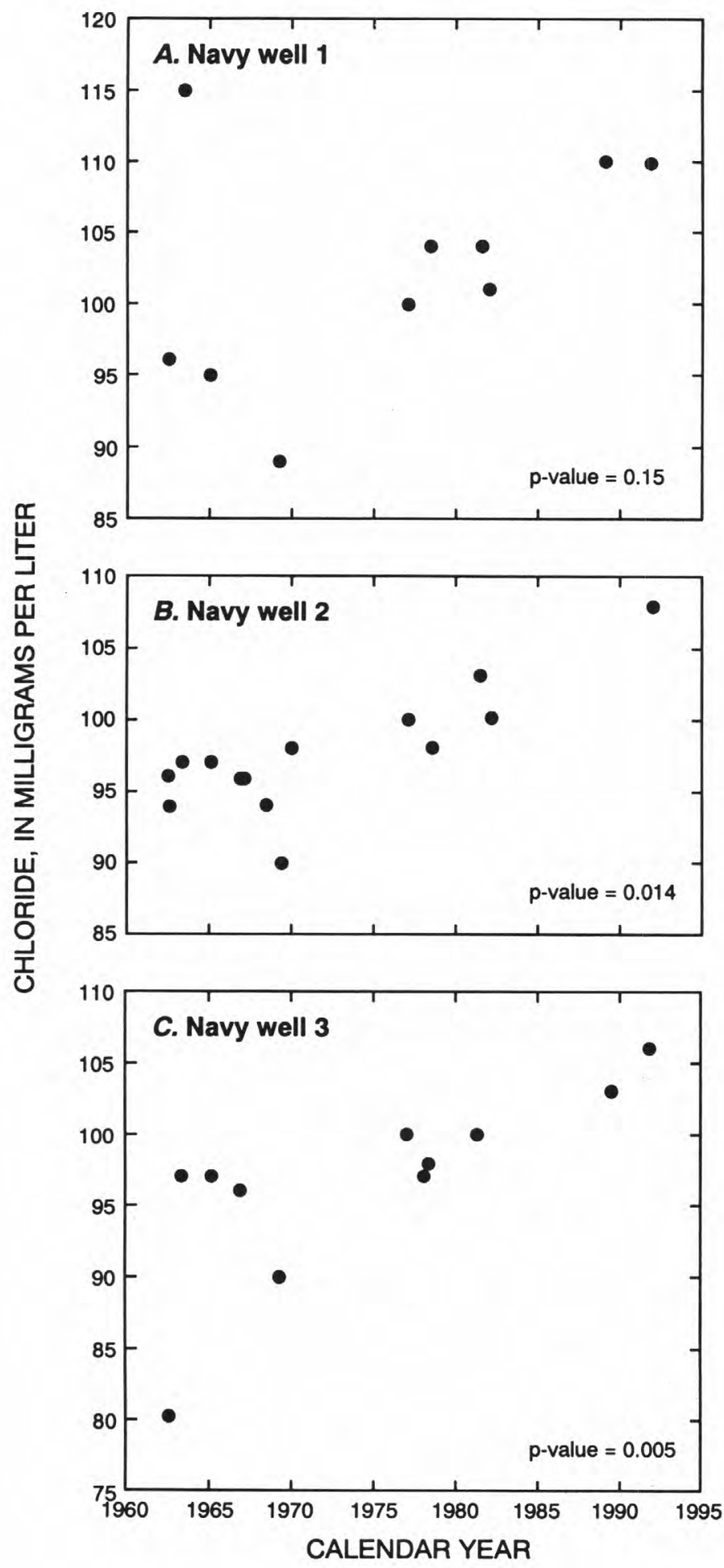

Figure 24. Chloride concentrations in ground water from three wells tapping basalt aquifer. Statistical p-values (Conover, 1980) were calculated by computer program ESTREND (Schertz and others, 1991). 
Table 3. Estimates of inflow to and outflow from Carson Desert

\begin{tabular}{lr}
\hline Flow component & Acre-feet per year \\
\hline INFLOW: & 370,000 \\
Surface-water releases from Lahontan Reservoir & minor \\
Seepage from Lahontan Reservoir & $2,000-25,000$ \\
Seepage from Truckee Canal and Swingle Bench irrigation & 20,000 \\
Recharge from precipitation & unknown \\
Recharge from precipitation on areas of sand dunes & $3 \mathbf{4}_{4,200}$ \\
Recharge from precipitation on areas where water table is shallow & \\
Inflow from adjacent basins & $\mathbf{4 0 0 , 0 0 0 - 4 2 0 , 0 0 0}$ \\
Total estimated inflow (rounded) & 198,000 \\
OUTFLOW: & ${ }_{58,000}$ \\
Evaporation from open-water bodies within surface-water distribution & 80,000 \\
$\quad$ system and evapotranspiration on irrigated lands & 113,000 \\
Evaporation from open-water bodies within wetlands & unknown \\
Evapotranspiration from wetlands & $27,000-8000$ \\
Evaporation from open-water bodies on playas & \\
Evapotranspiration from phreatophytes & $\mathbf{6 3 0 , 0 0 0 - 6 8 0 , 0 0 0}$ \\
Evaporation from discharging playa surface & \\
Outflow to adjacent basins & \\
Total estimated outflow (rounded) &
\end{tabular}

\footnotetext{
Estimates not otherwise noted are made by authors of this report.

2 From Glancy and Katzer (1975, p. 66).

3 From Glancy and Katzer (1975, p. 66), Van Denburgh and Arteaga (1985, p. 12), and this report.

4 From Clyde-Criddle-Woodward (1971, p. D-8).
}

Irrigation losses from about 900 acres of land along the Truckee Canal and seepage losses along the canal between Hazen and Lahontan Reservoir provide recharge to the Carson Desert. A total of about 8,000 acre-ft/yr is diverted from the Truckee Canal for irrigation of land within the Carson Desert along the Truckee Canal (Willis Hyde, Truckee-Carson Irrigation District, written and oral commun., 1993). CH2M Hill (1973, p. 4-16) estimate that 64 percent of water diverted in this area is lost to seepage, spill, and on-farm loss. Thus, about 5,000 acre-ft/yr from Truckee Canal diversions to irrigated land within Carson Desert could be available for recharge.

Estimates of seepage losses on the Truckee Canal range from about $0.8\left(\mathrm{ft}^{3} / \mathrm{s}\right) / \mathrm{mi}$ (Clyde-CriddleWoodward, 1971, p. 70) to about $4\left(\mathrm{ft}^{3} / \mathrm{s}\right) / \mathrm{mi}$ (Jon O. Nowlin, U.S. Geological Survey, written commun., 1981) between gaging stations above Fernley and near Hazen on the Truckee Canal. The reach between the hydrologic boundary of the Carson Desert and Lahontan Reservoir is about $7 \mathrm{mi}$. Thus, 5.6 to $28 \mathrm{ft}^{3} / \mathrm{s}$ could be lost through this reach. If this loss takes place throughout the year, as much as 4,000 to 20,000 acre-ft/yr could be lost to seepage along the reach.
Thus, total losses from the Truckee Canal between the hydrologic boundary of the Carson Desert and Lahontan Dam that are available to recharge the Carson Desert could range from 9,000 to about $25,000 \mathrm{acre}-\mathrm{ft} / \mathrm{yr}$ (table 3). More detailed data on losses through the Truckee Canal in the Carson Desert are required to refine this estimate.

The proximity of Mahala Slough and possibly Massie Slough to the Truckee Canal and irrigated lands of the Truckee Division suggests that water lost to seepage supports these wetland areas (pl. 1). Some recharge to the Carson Desert from the Truckee Canal probably also supports phreatophytes along the western margin of the basin.

Recharge from precipitation on the entire hydrographic area is estimated by Glancy and Katzer (1975, p. 48) to be 1,300 acre-ft/yr (table 3 ) on the basis of calculations using a method developed by Eakin (1951, p. 79-81). This method assumes that potential recharge is equal to varying percentages of the precipitation assumed to fall in different altitude zones. More detailed precipitation data in the area would permit refinement of the precipitation-altitude relations used by Glancy and Katzer (1975). For areas having altitudes less than $6,000 \mathrm{ft}$, annual 
Table 4. Estimated annual precipitation and potential ground-water recharge in the Carson Desert (Glancy and Katzer, 1975, p. 55)

\begin{tabular}{|c|c|c|c|c|c|c|}
\hline \multirow{3}{*}{$\begin{array}{l}\text { Altitude zone } \\
\text { (feet above } \\
\text { sea level) }\end{array}$} & \multirow[b]{3}{*}{$\begin{array}{l}\text { Area } \\
\text { (acres) }\end{array}$} & \multicolumn{3}{|c|}{ Estimated annual precipitation } & \multicolumn{2}{|c|}{ Estimated potential recharge } \\
\hline & & \multirow[b]{2}{*}{$\begin{array}{c}\text { Range } \\
\text { (inches) }\end{array}$} & \multicolumn{2}{|c|}{ Average } & \multirow[b]{2}{*}{$\begin{array}{l}\text { Percent of total } \\
\text { precipitation }\end{array}$} & \multirow[b]{2}{*}{$\begin{array}{l}\text { Acre-fee } \\
\text { per year }\end{array}$} \\
\hline & & & Feet & Acre-feet & & \\
\hline $8,000-8,790$ & 450 & $>15$ & 1.5 & 680 & 15 & 100 \\
\hline $7,000-8,000$ & 6,980 & $12-15$ & 1.1 & 7,700 & 7 & 540 \\
\hline $6,000-7,000$ & 26,800 & $8-12$ & 8 & 21,000 & 3 & 630 \\
\hline $3,845-6,000$ & $1,260,000$ & $<8$ & .5 & 630,000 & minor & minor \\
\hline Total (rounded) & $\overline{1,290,000}$ & -- & -- & $\overline{660,000}$ & -- & $\overline{1,300}$ \\
\hline
\end{tabular}

precipitation was assumed to be less than $8 \mathrm{in} / \mathrm{yr}$, and precipitation totaled about 630,000 acre-ft/yr for the entire Carson Desert. However, recharge from precipitation was assumed to be minor (table 4). The Stillwater Range is the only major mountain block higher than $6,000 \mathrm{ft}$ and, thus, is probably the source for most of the estimated 1,300 acre- $\mathrm{ft} / \mathrm{yr}$ of recharge.

Glancy and Katzer (1975, p. 67) recognized that potential discharge by evaporation and evapotranspiration from the basin is considerably greater than their estimates for inflow. In table 3, 1,300 acre-ft/yr is listed as one component of recharge to the Carson Desert from precipitation. Recent studies suggest that more recharge from precipitation than that estimated by Glancy and Katzer (1975) takes place.

Olmsted (1985, p. 15) suggests that, in areas of the Carson Desert having low annual precipitation, recharge can take place where the water table is near land surface or in areas where soil moisture is increased by seepage from the irrigation system. These conditions are present over large areas of the Carson Desert. Olmsted (1985, p. 15-19) also shows that, when low-lying areas were flooded during the wet years of 1982-83, water level rose several $\mathrm{ft}$ nearby in the shallow aquifer. He estimates that recharge of about 2,000 acre- $\mathrm{ft}$ took place in an area covering about $9 \mathrm{mi}^{2}$. Although the frequency of such flooding is low, hundreds of square miles in the Carson Desert have potential for recharge during these periods of ponding. More study could determine the magnitude of recharge from this source (table 3).

Recent studies estimate that, in areas of sand dunes lacking vegetation, recharge can range from 17 to 20 percent of the average annual precipitation (Berger, 1992, p. 964; Stephens and Knowlton, 1986, p. 888). Using land-use data from 1973 (U.S. Geological Survey, 1976), sand-covered areas in the
Carson Desert total about 277,000 acres. As much as 20,000 acre-ft/yr could potentially recharge the Carson Desert through sand dunes, assuming that average annual precipitation is $5 \mathrm{in}$. and 17 percent of this becomes recharge from sand-dune areas (table 3).

Previous estimates of surface-water and groundwater inflow to the basin from adjacent valleys total about 2,200 acre-ft/yr, with surface-water inflow of 1,400 acre- $\mathrm{ft} / \mathrm{yr}$-including 1,000 acre-ft/yr from the Humboldt River Basin (Glancy and Katzer, 1975, p. 66) - and ground-water inflow of 800 acre- $\mathrm{ft} / \mathrm{yr}$ (Glancy and Katzer, 1975, p. 66; Van Denburgh and Arteaga, 1985, p. 12). Since the work of Glancy and Katzer (1975), inflow to the Carson Sink from the Humboldt River totaled more than 1,000,000 acre-ft from 1983-85 (U.S. Geological Survey, 1986, p. 324). If flow of this magnitude takes place only once every 100 years, the average inflow would be over 3,000 acre-ft/yr, or an additional 2,000 acre- $\mathrm{ft} / \mathrm{yr}$. This value will be used as most representative of long-term inflow from the Humboldt River Basin, increasing the estimate for total inflow from adjacent basins to 4,200 acre-ft/yr.

\section{Components of Outflow}

Outflow from the basin takes place by evaporation from open-water bodies, bare soil, and evapotranspiration from crops, phreatophytes, and non-crop vegetation.

Glancy and Katzer (1975, p. 64) estimated that $220,000 \mathrm{acre}-\mathrm{ft} / \mathrm{yr}$ is lost to evaporation from openwater bodies in the Carson Desert, including evaporation from 45,000 acres of perennial lakes and ponds, and from 20,000 acres of water ponded intermittently 
on playas. They also report a total of 170,000 acre$\mathrm{ft} / \mathrm{yr}$ lost to irrigated crops, phreatophytes on nonirrigated lands, and discharging playa surfaces. Glancy and Katzer acknowledge that this value probably is low, but is required to balance their basinwide water budget. Reports discussed below allow refined estimates for components of outflow from the ground-water basin.

As reported in the surface-water section of this report, average historical losses of surface water released from Lahontan Reservoir were 198,000 acre$\mathrm{ft} / \mathrm{yr}$ (table 1, column 8, nonrounded average) upstream from the wetland areas (table 3). Also, water lost to evaporation from open-water bodies and evapotranspiration near wetland areas was estimated to be 58,000 and 155,000 acre-ft/yr, respectively (table 3). Surface-water losses upstream from wetland areas represent evaporation from open-water bodies within the distribution system and evapotranspiration from irrigated land. As shown by Seiler and Allander (1993), long-term shallow water levels and, thus, ground-water storage has not changed greatly from the mid-1970's to 1992. Therefore, seepage losses that do not supply consumptive use on irrigated lands are accounted for by measured surfacewater outflow, evaporation from playas, and evapotranspiration by phreatophytes.

Glancy and Katzer (1975, p. 64) estimated that evaporation from 20,000 acres of ponded playa surfaces totaled 40,000 acre- $\mathrm{ft} / \mathrm{yr}$. They used an evaporation rate of $2 \mathrm{ft} / \mathrm{yr}$, because ponding is present during less than half of each year. Because the relative contributions of ponded water from the Carson River compared with those from the Humboldt River are not known, the additional average inflow of 2,000 acre-ft/yr from the Humboldt River during flood years might increase the area of ponding by 20,000 acres. This assumes that the average depth of ponding is $0.1 \mathrm{ft}$. Thus, evaporation from water ponded on playas could average 80,000 acre-ft/yr from 40,000 acres of ponded water.

Discharge by phreatophytes outside irrigated areas of the Carson Desert can be estimated from reported rates of evapotranspiration and the extent of phreatophytes (fig. 1) as delineated by Glancy and Katzer (1975, pl. 1). However, the distribution of the types of phreatophytes and their density is highly variable in the Carson Desert. The type and density of phreatophytes have not been mapped for the entire Carson Desert, and changes in the distribution of phreatophytes, bare soil, and open water for years with varying amounts of annual precipitation and runoff have not been documented. These additional data would allow refinement of estimates of discharge for the Carson Desert.
Estimates for the rate of evapotranspiration by phreatophytes in the Carson Desert vary considerably and are based on limited data. Morgan (1982, p. 36) used a rate of $0.6 \mathrm{ft} / \mathrm{yr}$ for stands of saltgrass and greasewood or rabbitbrush, and $0.4 \mathrm{ft} / \mathrm{yr}$ for sparsely vegetated areas near the town of Stillwater. Olmsted and others $(1975$, p. 115) used a rate of $0.2 \mathrm{ft} / \mathrm{yr}$ for discharge by evapotranspiration near the Soda Lake/Upsal Hogback area. Carman (1994) measured an evapotranspiration rate of about $0.6 \mathrm{ft} / \mathrm{yr}$ in a stand of greasewood, shadscale, and saltcedar north of Soda Lake where depth to water was about $25 \mathrm{ft}$ below land surface. Much higher rates, ranging from 1.5 to $2.5 \mathrm{ft} / \mathrm{yr}$ were used by Clyde-Criddle-Woodward (1971, p. D-7) for varying densities of greasewood.

Evapotranspiration rates of generally less than $1 \mathrm{ft} / \mathrm{yr}$ for various types of phreatophytes were used in reconnaissance investigations by the USGS to obtain reasonable water budgets for many basins in Nevada. William D. Nichols (U.S. Geological Survey, written commun., 1993) measured evapotranspiration rates for phreatophyte stands in several basins in Nevada. These rates vary from 0.08 to $1.01 \mathrm{ft} / \mathrm{yr}$, depending upon the plant type, density, leaf area, and depth to water.

For this study, an evapotranspiration rate of 0.3 $\mathrm{ft} / \mathrm{yr}$ is used to obtain a conservative estimate of discharge by phreatophytes outside of irrigated lands in the Carson Desert. The extent of phreatophytes and irrigated lands as mapped by Glancy and Katzer (1975, pl. 1) covers an area of 435,000 acres. Subtracting 57,000 acres, the average area of irrigated lands from 1984 to 1990 , phreatophytes outside of irrigated lands cover about 378,000 acres in the Carson Desert. Applying an evapotranspiration rate of $0.3 \mathrm{ft} / \mathrm{yr}$ results in a discharge of about 113,000 acre-ft/yr (table 3). This value is less than an estimate by Clyde-Criddle-Woodward (1971, p. C-2 and D-8) of about 165,000 acre-ft/yr lost to evapotranspiration from phreatophytes near both the Truckee and Carson Divisions. However, maps showing the distribution of phreatophytes, as used by ClydeCriddle-Woodward (1971), are not available to derive an estimate for only the Carson Division or for comparison with the distribution mapped by Glancy and Katzer (1975, pl. 1). Collection of evapotranspiration data in the Carson Desert for different plant types, densities, leaf areas, and depths to water, combined with data on the distribution of phreatophytes, would allow refinement of the estimate for discharge from the Carson Desert. 
Discharging playa in the Carson Desert covers about 268,000 acres as delineated by Glancy and Katzer (1975, pl. 1). Estimates for the rate of ground-water discharge from playas range from $0.1 \mathrm{ft} / \mathrm{yr}$ in the Smoke Creek Desert (Glancy and Rush, 1968, p. 32) to $0.3 \mathrm{ft} / \mathrm{yr}$ near geothermal areas in Nevada (Olmsted and others, 1975, p. 72). As noted by Olmsted and others $(1975$, p. 73$)$, the rate of discharge from playas depends on depth to water table, salinity of ground water, temperature, and presence of a surficial salt crust. Variations in wind patterns probably also effect the rate of playa discharge. Because these characteristics vary greatly in the Carson Desert, application of a constant rate will provide only an approximate volume. Using rates of 0.1 and $0.3 \mathrm{ft} / \mathrm{yr}$ and an area of 268,000 acres, 27,000 to 80,000 acre-ft/yr could be lost to discharge from playas in the Carson Desert (table 3). More data on rates of discharge from playa surfaces would permit refinement of this estimate.

Because the floor of Dixie Valley to the east is about $500 \mathrm{ft}$ lower in altitude than the floor of the Carson Desert, a potential for flow, or discharge, from the Carson Desert to Dixie Valley exists. However, because intervening rocks beneath the Stillwater range are consolidated, this volume of flow is presently thought to be minimal.

As shown by table 3, the water budget for the Carson Desert does not balance. Total discharge $(630,000-680,000 \mathrm{acre}-\mathrm{ft} / \mathrm{yr})$ is much greater than the amount estimated to recharge the basin $(400,000$ 420,000 acre-ft/yr). Recharge from areas where the water table is shallow could account for some of the difference. Further study of recharge from precipitation in sand-dune areas and areas where the depth to water is shallow, and of discharge from playa surfaces, phreatophytes, and wetland areas could resolve uncertainties for components of the basin-wide water budget.

\section{Flow Through Individual Aquifers}

The following sections discuss (1) evidence showing the location of ground-water flow between aquifers in the Carson Desert, and (2) estimates of the volumes of water that flow between the surface-water system and the aquifers and between individual aquifers. The processes of recharge to and discharge from the entire Carson Desert were discussed in the previous section. In this section, estimates of recharge to the shallow aquifer near irrigated land are discussed, along with estimates for the volumes of ground-water flow between the shallow, intermediate, and basalt aquifers.

\section{Qualitative Evidence}

Glancy (1986, p. 27, 55) presented evidence showing where water could flow between the shallow, intermediate, and basalt aquifers (fig. 12). Waterquality data can be used to evaluate whether groundwater flow actually takes place in areas where the potential for flow has been reported.

The shallow aquifer overlies all other aquifer systems in the Carson Desert except near Rattlesnake Hill, where the basalt aquifer crops out. Thus, processes that control recharge to and discharge from the shallow aquifer also affect recharge to and discharge from the intermediate, deep, and basalt aquifers. A large part of the recharge to and discharge from the ground-water system in the basin could take place through a near-surface zone in the shallow aquifer, as discussed in the section "Description of Aquifers" (p. 32). However, defined boundaries for the nearsurface zone are unknown, thus limiting the ability to estimate recharge and discharge through this zone. Therefore, the shallow aquifer, as defined by Glancy (1986), is used in this section as the uppermost aquifer through which most recharge and discharge takes place.

The shallow aquifer is potentially recharged by surface-water flow throughout the basin and by the intermediate aquifer near ground-water discharge areas. Lico and Seiler (written commun., 1993) give supporting evidence that this flow takes place by using stable isotopes and tritium activities. They show that water in the shallow aquifer is derived from (1) surface water released from Lahontan Reservoir of the Carson River and Truckee Canal beneath irrigated areas, and from (2) ground water of the intermediate aquifer in discharge areas at Stillwater WMA and Carson Lake. The water-quality analysis discussed previously also suggests that irrigation has affected water quality in the shallow aquifer and that, near ground-water discharge areas, the shallow aquifer is recharged by the intermediate aquifer. The volume of recharge, areas where surface-water recharges the shallow aquifer, and where the intermediate aquifer recharges the shallow aquifer cannot be delineated without additional data.

The shallow aquifer also discharges water to surface-water flow through the network of drains in the Carson Division. On the basis of water-quality data, the shallow aquifer is reported to be the source for drain flow near Stillwater WMA, the Fallon Indian Reservation, and the Newlands Field Laboratory (Tokunaga and Benson, 1991, p. xiv; Hoffman and others, 1990, p. 31; Lico, 1992, p. 18; Tabaei, 1991, p. 46). Additional data on water levels that show potential for flow from the shallow aquifer 
to the drain system, on surface-water flow that shows where flow increases in drains, and on water quality could more precisely delineate the volume and location of shallow-aquifer discharge to drains.

Water-level data show the potential for the shallow aquifer to recharge the intermediate aquifer in the west and central parts of the basin. Water-quality data show that the hardness of water in the western part of the intermediate aquifer is similar to that in the shallow aquifer, although dissolved-solids and arsenic concentrations are not similar in each aquifer in that area. The observed differences between water quality in the two aquifers indicate that recharge from dilute surface water to the intermediate aquifer takes place preferentially through zones of high permeability.

Lico and Seiler (written commun., 1993) note that, west of Soda Lake, the stable-isotope composition and tritium activities in ground water from the intermediate aquifer indicate recent recharge either from the surface-water system or from the shallow aquifer. East of Soda Lake however, these indicators show that ground water from the intermediate aquifer has, at least in part, been recharged by other sources. Lico and Seiler (written commun., 1993) suggest that the most likely sources are recharge from surrounding mountain blocks or recharge from surface-water several hundred years in the past.

Water levels indicate the potential for recharge from the shallow and intermediate aquifers in the southwestern part of the basalt aquifer and discharge from the basalt aquifer to the shallow and intermediate aquifers in the northeastern part. Glancy (1986, p. 21,31 ) presents data on dissolved solids, stable isotopes, and tritium activities showing that ground water in the basalt aquifer is a blend of water from the intermediate and deep aquifers and that, near areas of pumping, water from either the shallow aquifer or the surface-water system has recharged the basalt aquifer. Lico and Seiler (written commun., 1993) report similar conclusions using water-quality data from additional sites. They also note that ground water in the intermediate aquifer southeast of and downgradient from the basalt aquifer is chemically similar to that of the basalt aquifer. This indicates that the basalt aquifer recharges the intermediate aquifer (Michael S. Lico and Ralph L. Seiler, written commun., 1993).

The shallow aquifer is in contact with the basalt aquifer only near Rattlesnake Hill. This area is also near the wells that pump water from the basalt aquifer so that flow is induced from the shallow aquifer to the basalt aquifer. Thus, the basalt aquifer probably does not directly supply significant flow to the shallow aquifer. However, because the intermediate aquifer does receive flow from the basalt aquifer downgradient from the basalt, and the intermediate aquifer is shown to supply water to the shallow aquifer in this area, an indirect connection for discharge from the basalt to the shallow aquifer is present.

Water also discharges from the shallow aquifer by evapotranspiration and by bare-soil evaporation. This is supported by data on ground-water quality as discussed earlier in this report.

\section{Quantitative Estimates}

Few quantitative estimates of flow between aquifers in the Carson Desert have been made. This section summarizes estimates reported in the literature and made during this study. Figure 25 summarizes estimates for the volumes of flow between the surface- and ground-water systems and between individual aquifers. Inflow to and outflow from the shallow, intermediate, and basalt aquifers are totaled to summarize the components of flow. However, unknown components of flow exist, and no attempt was made in this report to balance inflow and outflow. Using available data and Darcy's Law, estimates are made for components of inflow, outflow, and lateral flow within the aquifers to approximately determine the relative magnitude of flow possible within and between the aquifers. The volumes of flow are based on reported aquifer properties at isolated sites within the Carson Desert that are assumed to represent larger areas. This assumption may not be valid, possibly resulting in errors in the calculated volumes of flow by an order of magnitude or more.

Recharge to the shallow aquifer was estimated by Olmsted and others $(1975$, p. 80$)$ to be more than half of the surface water released from Lahontan Reservoir. Using the representative estimate for releases from the reservoir from 1975-92, this amounts to more than 190,000 acre-ft/yr.

Using observed water-level changes, Glancy (1986, p. 39) calculated a volume of 26,000 to 27,000 acre-ft/yr for both recharge to and discharge from the shallow aquifer during 1977-78 in an area generally corresponding to irrigated lands. This volume is much less than other estimates of shallow ground-water recharge, however it is based on measured water-level changes and an assumed specific yield of 10 percent.

No data are available describing the specific yield of aquifer materials in the Carson Desert and the value of 10 percent used by Glancy (1986, p. 39), is the only reported estimate. Estimates of the specific yield for sediments in the Humboldt River Basin 
Total in (rounded); 126,000

Total out (rounded): 129,000

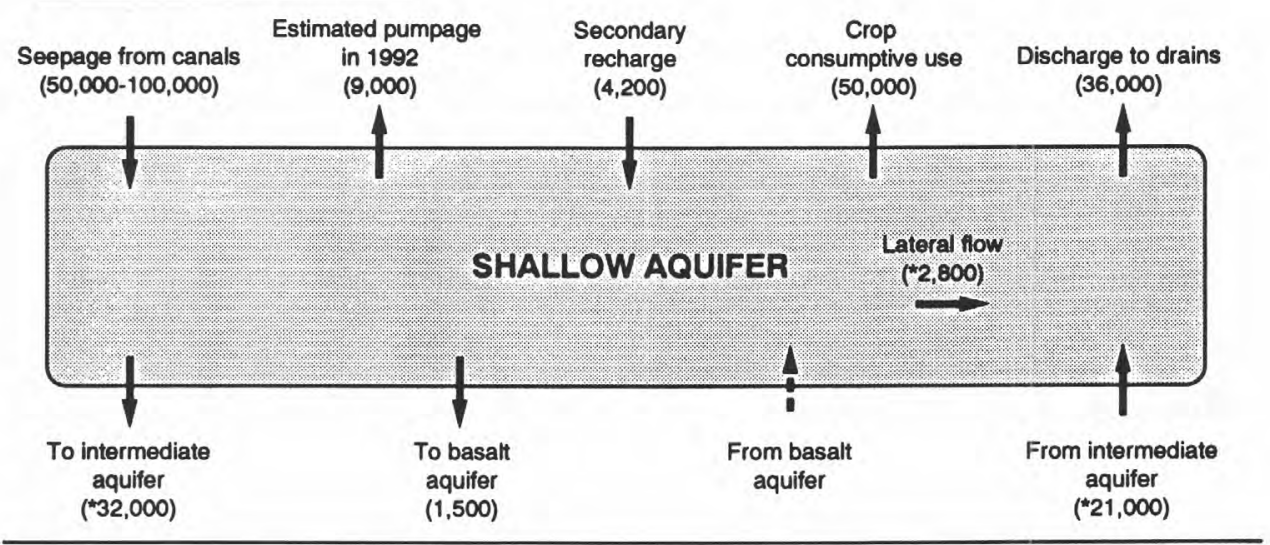

Total in (rounded): $\mathbf{3 3 , 0 0 0}$

Total out (rounded): 25,000

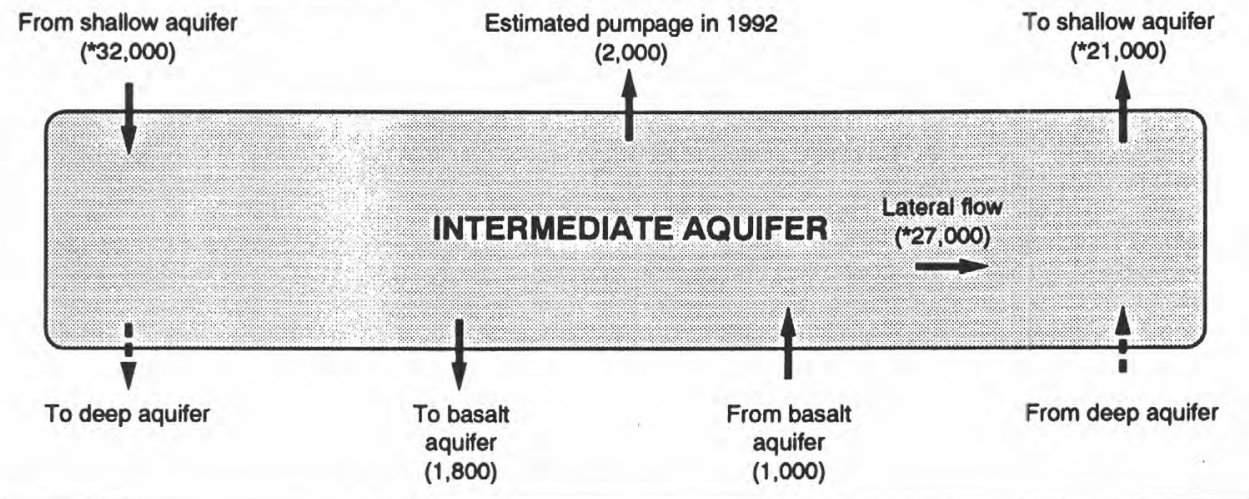

Total in (rounded): 4,000

Total out (rounded): 4,000

Pumpage in 1992

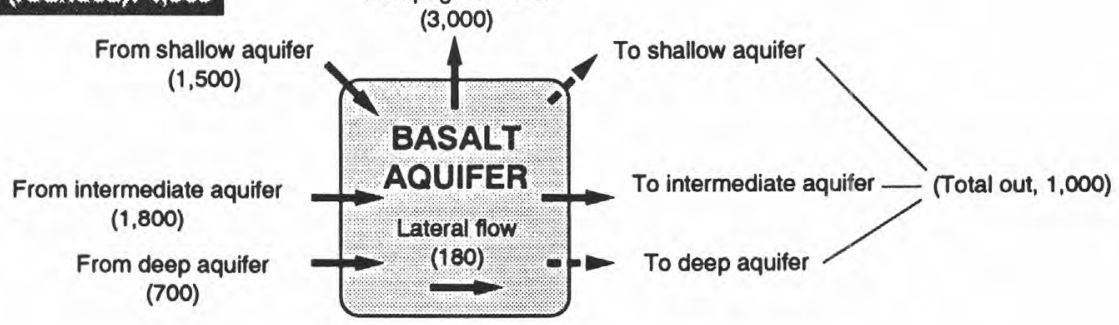

Figure 25. Estimated recharge to, discharge from, and lateral flow within shallow, intermediate, and basalt aquifers, in acre-feet per year. Asterisks indicate volumes estimated using assumed values for aquifer properties; these volumes could be in error by an order of magnitude or more. Volumes from basalt aquifer are estimated from pumpage in 1992 and relation of Glancy (1986, fig. 12); all others are estimated in this report. Dashed arrow indicates occurrence uncertain. 
(Cohen, 1963, table 27) are less than 1 percent for clay, 19 percent for silt, 20 to 28 percent for sand, and 18 to 19 percent for gravel. Other estimates of specific yield based on grain size show that sand and silt can have specific yields as high as 40 and 30 percent, respectively, depending sorting in the sediment (Davis and DeWiest, 1966, p. 375 and 377). Thus, the specific yield of aquifer materials probably varies greatly.

The area where water levels were used by Glancy (1986, p. 47) to estimate recharge includes a wide range in depositional environments. Thus the deposits forming the shallow aquifer have a wide range in grain size and sorting. If the average specific yield of the shallow aquifer is as much as 20 percent, Glancy's (1986) estimate of recharge would double to more than 50,000 acre- $\mathrm{ft} / \mathrm{yr}$. Studies to determine the range and distribution of specific yield in the Carson Desert are essential to estimate (1) recharge from observed changes in water levels and (2) the potential change in water levels from changes in irrigation practices.

Available estimates of surface water lost to seepage range from about 50,000 to $100,000 \mathrm{acre}-\mathrm{ft} / \mathrm{yr}$ (table 2). Comparing magnitudes of releases from Lahontan Reservoir with outflow from irrigated lands suggests that minimum releases of about 70,000 acre$\mathrm{ft} / \mathrm{yr}$ are required to recharge the shallow aquifer before outflow takes place. Thus recharge to the shallow aquifer from seepage is probably 50,000 100,000 acre-ft/yr (fig. 25).

Discharge from the shallow aquifer to consumptive use on irrigated land is estimated to be about 50,000 acre- $\mathrm{ft} / \mathrm{yr}$ (table 2, fig. 25). Water is also discharged from the shallow aquifer by pumpage and by flow to drains.

Available data show that as many as 4,500 wells could currently pump water from the shallow aquifer. Assuming that if about 2 acre-ft from every well (the maximum volume allowed by State law from a domestic well) is pumped annually, as much as 9,000 acre-ft/yr could be withdrawn from the shallow aquifer (fig. 25).

Because most domestic water users have septic systems and use water for lawn or garden supply, a large part of the pumped water probably returns to the shallow aquifer as what is often called secondary recharge (Harrill, 1973, p. 62). If secondary recharge is about 30 percent of pumpage (Harrill, 1973, p. 64) the net withdrawal is about 6,000 acre- $\mathrm{ft} / \mathrm{yr}$ and secondary recharge of pumped water is about 3,000 acre-ft/yr. Also, secondary recharge to the shallow aquifer from water pumped from the intermediate aquifer could be about 600 acre-ft/yr. Lawn watering that uses pumpage from the basalt aquifer probably also supplies secondary recharge to the shallow aquifer. Harrill (1973, p. 62) estimates that about 20 percent of domestic water use recharges the water table from lawn watering. Thus, lawn watering from basalt pumpage could supply an additional 600 acre$\mathrm{ft} / \mathrm{yr}$ of recharge to the shallow aquifer. Secondary recharge from pumpage for irrigation probably is minimal. Secondary recharge to the shallow aquifer from domestic and municipal pumping could total about 4,200 acre-ft/yr (fig. 25).

An estimate for the minimum volume of water discharged from the shallow aquifer to drains can be made from the total outflow from irrigated lands during non-irrigation months when releases from Lahontan Reservoir are minimal. To obtain this estimate, gaged releases from Lahontan Reservoir for years of minimal precautionary drawdown are subtracted from the total of flow measured on the Carson River above Carson Sink and the flow measured and estimated in drains from 1975-92 for December and January. The resulting monthly average is about 3,000 acre-ft using data from the U.S. Geological Survey (1975-92) and the U.S. Fish and Wildlife Service (Norman A. Saake, written commun., 1993). During winter months, outflow from irrigated lands could contain some flow derived from precipitation runoff and, during irrigation months, the volume moving from the shallow aquifer to drains is probably larger. An accurate estimate of seepage from the shallow aquifer to drains cannot be calculated, because outflow during irrigation months is a mixture of operational spill, runoff from irrigated fields, and seepage from the shallow aquifer. If $3,000 \mathrm{acre}-\mathrm{ft} / \mathrm{mo}$ is the minimum volume of baseflow in drains throughout the year, a volume of 36,000 acre-ft/yr represents a minimum value for discharge from the shallow aquifer to the surface-water system (fig. 25).

Using the above estimates, inflow to and outflow from the shallow aquifer could be over 120,000 acre-ft/yr (fig. 25). However, uncertainties in components of inflow and outflow of more than an order of magnitude make these values approximate.

Glancy (1986, p. 58) used a mathematical method to estimate the relation between recharge, pumpage, and discharge from the basalt aquifer (fig. 14). $\mathrm{He}$ found that recharge to the basalt aquifer prior to pumping was about 2,500 acre-ft/yr, and that recharge induced by pumping at about 1,700 acre-ft/yr during 1976-78 was about 900 acre-ft/yr. He also found that all discharge from the basalt aquifer would cease at a pumping rate of about $8,500 \mathrm{acre}-\mathrm{ft} / \mathrm{yr}$. The method assumed that flow through the aquifer is controlled by the hydraulic conductivity of sediments bounding the aquifer on the discharge (northeast) side and that only 
vertical flow was recharging the aquifer. Glancy (1986, p. 33) also estimated that lateral flow through the basalt aquifer was about $180 \mathrm{acre}-\mathrm{ft} / \mathrm{yr}$, supporting the assumption that the aquifer is recharged mainly by vertical flow.

As mentioned in the section describing the aquifers, Glancy's (1986, p. 30) relation between pumping and recharge to and discharge from the basalt aquifer is supported by observed water-level declines and estimates of pumpage in 1992 . Using the relation in figure 14 , and the present pumping rate of about $3,000 \mathrm{acre}-\mathrm{ft} / \mathrm{yr}$ from the basalt aquifer, recharge to the basalt aquifer is slightly more than 4,000 acre$\mathrm{ft} / \mathrm{yr}$ and discharge to the shallow and intermediate aquifers downgradient from the basalt aquifer is about 1,000 acre-ft/yr (fig. 25).

Recharge induced by pumping makes up about $1,500 \mathrm{acre}-\mathrm{ft} / \mathrm{yr}$ of the total 4,000 acre-ft/yr recharge. Because the shallow aquifer is in contact with the basalt aquifer only near the area of the pumping from the basalt aquifer, much of the induced recharge to the basalt aquifer could come from the shallow aquifer as shown by water-quality data (fig. 25). This leaves recharge of 2,500 acre-ft/yr from both the intermediate and deep aquifers. Glancy $(1986$, p. 21) calculated that, if the dissolved-solids concentration in the deep aquifer is $1,500 \mathrm{mg} / \mathrm{L}, 73$ percent of the recharge to the basalt aquifer is derived from the intermediate aquifer and 27 percent is derived from the deep aquifer. The proportion of recharge derived from the intermediate aquifer would increase to 96 percent if the dissolved-solids concentration is as high as $10,000 \mathrm{mg} / \mathrm{L}$ in the deep aquifer. Lico and Seiler (written commun., 1993) report that the dissolvedsolids concentration in ground water near the basalt aquifer at a depth of $1,700 \mathrm{ft}$ is about $1,000 \mathrm{mg} / \mathrm{L}$. Thus, the dissolved-solids concentration in the deep aquifer probably is closer to $1,500 \mathrm{mg} / \mathrm{L}$. Using Glancy's (1986) proportions, about 1,800 acre-ft/yr could be derived from the intermediate aquifer and about 700 acre-ft/yr could be derived from the deep aquifer (fig. 25).

Water-quality data show that flow takes place from the basalt aquifer to the intermediate aquifer, and that the shallow aquifer recharges the basalt aquifer. For these reasons, most of the 1,000 acre$\mathrm{ft} / \mathrm{yr}$ discharging from the basalt aquifer probably recharges the intermediate aquifer. Inflow to and outflow from the basalt aquifer totals about 4,000 acre-ft/yr (fig. 25).

No quantitative estimates for recharge to or discharge from the intermediate or deep aquifers have been reported. An approximate estimate of recharge to the intermediate aquifer from the shallow aquifer can be calculated from the area of potential downward flow (fig. 12) and reported values for the vertical gradient and vertical hydraulic conductivity. Flow is calculated using Darcy's law:

$$
Q=K I A,
$$

where $Q$ is the rate of recharge, $K$ is the vertical hydraulic conductivity, $I$ is the vertical gradient, and $A$ is the area shown in figure 12 .

The area shown with a downward potential for flow from the shallow aquifer to the intermediate aquifer covers about 90,000 acres (fig. 12). Reported downward gradients, as previously discussed, range from 0.07 to $0.1 \mathrm{ft} / \mathrm{ft}$. Vertical hydraulic conductivities reported by Olmsted $(1985$, p. 42-44) near the Soda Lake/Upsal Hogback area average about $9.84 \times 10^{-3} \mathrm{ft} / \mathrm{d}$. Near the town of Stillwater, Morgan $(1982$, p. 50$)$ used a value of $0.3 \mathrm{ft} / \mathrm{d}$ for the vertical hydraulic conductivity of what was called a "fairly impermeable" boundary. Thus, estimates of hydraulic conductivity in the Carson Desert vary by two or more orders of magnitude. The vertical hydraulic conductivity is probably highly variable throughout the Carson Desert. However, on the western side of the basin where there is a potential for downward flow, vertical conductivity is probably higher than on the eastern side of the basin where basin-fill deposits are finer grained. Because the value reported by Olmsted and others (1984) is an average of more than 40 estimates from wells in the western part of the basin, it will be used to estimate the volume of downward flow.

Using the value of $9.84 \times 10^{-3} \mathrm{ft} / \mathrm{d}$ for vertical hydraulic conductivity, a value of $0.1 \mathrm{ft} / \mathrm{ft}$ for the downward gradient, and 90,000 acres for the area, a volume of about 32,000 acre- $\mathrm{ft} / \mathrm{yr}$ is obtained for downward flow from the shallow aquifer to the intermediate aquifer (fig. 25). If the vertical hydraulic conductivity used to calculate vertical flow is increased or decreased by an order of magnitude, the resulting volume of flow will also increase or decrease by an order of magnitude.

In a similar manner, an estimate for upward flow from the intermediate aquifer to the shallow aquifer can be calculated by assuming that upward flow is uniform in the basin outside the area with potential for downward flow. This area totals about 605,000 acres (fig. 12). Upward gradients near the town of Stillwater as reported by Morgan (1982, pl. 3) range from $0.03 \mathrm{ft} / \mathrm{ft}$ to as much as $0.2 \mathrm{ft} / \mathrm{ft}$ and average about $0.1 \mathrm{ft} / \mathrm{ft}$. Using an upward vertical gradient of $0.1 \mathrm{ft} / \mathrm{ft}$ and decreasing the vertical hydraulic conductivity to $9.84 \times 10^{-4} \mathrm{ft} /$ day because sediments are finer in the eastern part of the basin, a volume of about 21,000 acre-ft/yr is obtained for upward flow from the intermediate aquifer to the shallow aquifer 
(fig. 25). Again, this value could easily be adjusted by an order of magnitude in either direction by using a different value for the vertical hydraulic conductivity. Additional measurements of vertical hydraulic conductivity could permit a more accurate determination of the volumes of water moving between the shallow and intermediate aquifers.

Using Darcy's law and gradients measured by Glancy (1986) and Seiler and Allander (1993, Appendixes 1 and 3 ) below irrigated lands, lateral flow from recharge to ground-water discharge areas through both the shallow and intermediate aquifers can be estimated. Glancy (1986, p. 38) reports an average gradient in the shallow aquifer of about $7.5 \mathrm{ft} / \mathrm{mi}$ or about 1.4 $x 10^{-3} \mathrm{ft} / \mathrm{ft}$, supported by the more recent measurements by Seiler and Allander (1993, p. 17). The lateral hydraulic conductivity reported by both Olmsted and others (1984, p. 38) and Morgan (1982, p. 47) in the upper $150 \mathrm{ft}$ of aquifer material is about $40 \mathrm{ft} / \mathrm{d}$.

Using a cross-sectional length of $25 \mathrm{mi}$ along the $3,950-\mathrm{ft}$ line of equal water-table altitude in the shallow aquifer (fig. 10) and a saturated thickness of $45 \mathrm{ft}$, the estimated lateral flow through the shallow aquifer would be about 2,800 acre- $\mathrm{ft} / \mathrm{yr}$. This volume is applicable only to the approximate center of the lateral-flow zone, as shown in figure 12; vertical components of ground-water flow also exist within this zone. However, the calculation shows that most interchange of flow through the shallow aquifer probably is in the vertical direction.

For the intermediate aquifer, Glancy (1986, p. 51) reports an average gradient of $6.5 \mathrm{ft} / \mathrm{mi}$ or about $1.2 \times 10^{-3} \mathrm{ft} / \mathrm{ft}$. Using the same hydraulic conductivity and cross-sectional length, and an aquifer thickness of $500 \mathrm{ft}$, the estimated lateral flow through the intermediate aquifer would be 27,000 acre-ft/yr (fig. 25). As in the calculations for vertical flow, the estimates for lateral flow could be higher or lower by an order of magnitude or more.

As many as 1,000 wells may yield water from the intermediate aquifer. If about 2 acre- $\mathrm{ft}$ from every well is pumped annually, more than 2,000 acre$\mathrm{ft} / \mathrm{yr}$ could be withdrawn from the intermediate aquifer (fig. 25). As stated previously, $600 \mathrm{acre}-\mathrm{ft} / \mathrm{yr}$ of this water could return to the shallow aquifer as secondary recharge.

Using the above estimates, inflow to and outflow from the intermediate aquifer totals from 25,000 to more than 30,000 acre-ft/yr (fig. 25). This suggests that flow through the intermediate aquifer could have a large horizontal component. Again, uncertainties in the estimates for inflow and outflow components of more than an order of magnitude make this value very approximate.

Upflow of as much as 4,000 acre-ft of geothermal water as old as 35,000 years to the intermediate and shallow aquifers could be considered recharge to the present ground-water flow system. Because the geothermal water is thought to have originated from the Carson Desert (Olmsted and others, 1984, p. 76; Morgan, 1982, p. 88, 89), an equal volume probably flows from the shallow, intermediate, and deep aquifers to the geothermal aquifer.

\section{CONCEPTUAL MODELS OF GROUND- WATER FLOW}

The hydrologic system in the Carson Desert is complex and remains poorly understood despite many years of data collection and study of the area. Despite the complexities, generalizations about how ground water moves in the Carson Desert are possible. The following section presents conceptual diagrams and descriptions of processes that are important in controlling ground-water flow at different locations in the Carson Desert. Because of the complexity and incomplete understanding of the hydrologic systems, these diagrams are both idealized and hypothetical. Also, the conceptual diagrams depict ground-water movement at different scales. Limitations of the conceptual models are discussed in the following section.

Ground-water flow systems of many different scales are present in the basin. The flow systems range in scale from geothermal systems with periods of circulation as great as 35,000 years, flow paths with lengths of more than $4 \mathrm{mi}$, and flow depths as great as $10,000 \mathrm{ft}$ below land surface, to shallow ground-water systems that interact with the surfacewater system and have periods of circulation probably on the order of days, flow paths with lengths measured in tens to hundreds of feet, and flow depths of less than $20 \mathrm{ft}$ below land surface. The volume of water moving through these flow systems is inversely proportional to their scale. A large volume of water moves through the near-surface systems, and proportionally smaller volumes move through the flow systems as they increase in scale, length of flow path, and depth of flow. 


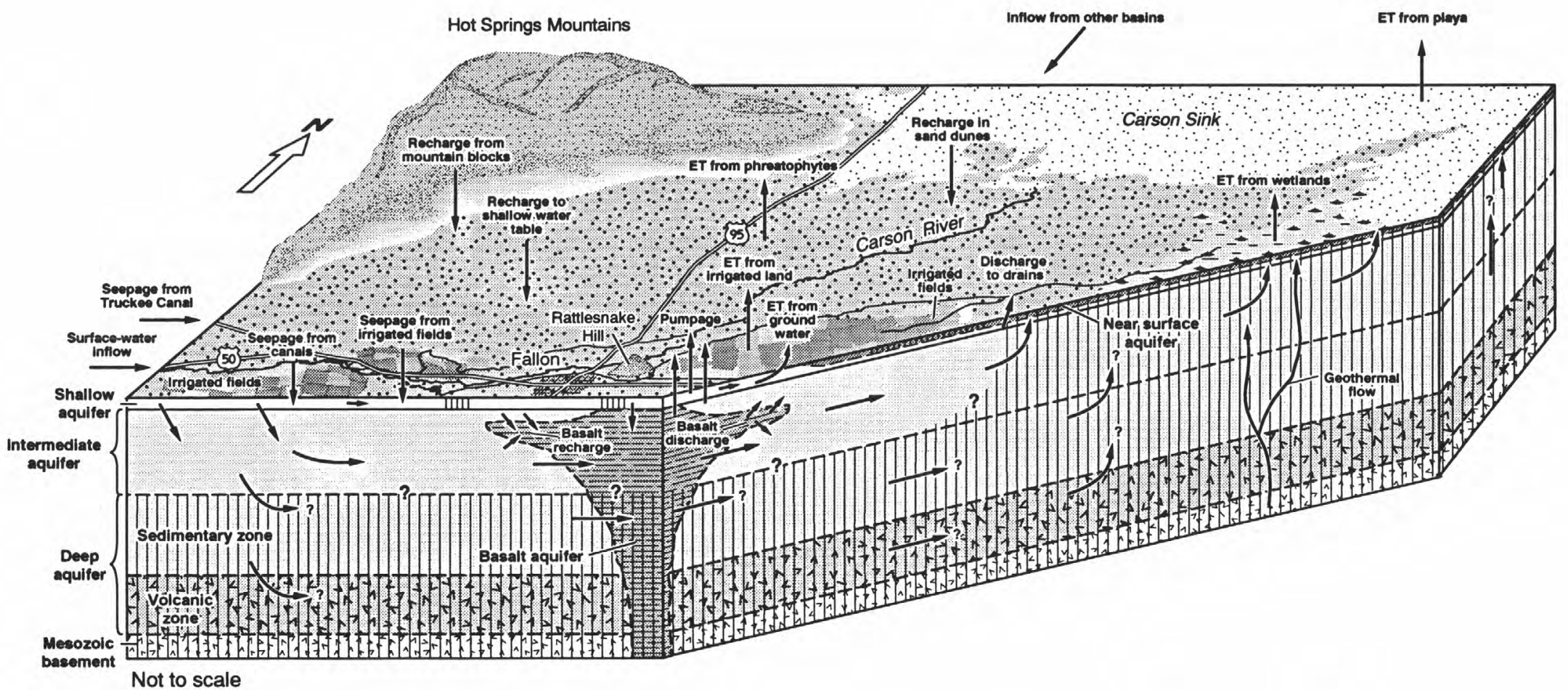

Figure 26. Conceptualized ground-water flow paths and sources of inflow to and outflow from aquifers in Carson Desert. ET, evapotranspiration. Boundaries between aquifers are dashed where uncertain; arrows depicting ground-water flow paths are queried where uncertain. Vertical line pattern indicates possible extent of nonpotable water. 


\section{Description of Conceptual Models}

\section{General Overview}

Figure 26 shows the general location and direction of flow between surface-water and groundwater systems and between individual aquifers in the Carson Desert.

Inflow from surface sources to the groundwater flow system comes from Lahontan Reservoir releases; seepage along the Truckee Canal; precipitation on mountain blocks, sand dunes, and areas where the depth to water is shallow; and adjacent basins. Evapotranspiration from irrigated lands, wetland areas, and phreatophytes, and evaporation from open-water bodies, bare soil, and playa surfaces are sources of discharge from the ground-water system.

Ground water flows between the shallow, intermediate, and deep aquifers and the basalt aquifer. Recharge from surface water in the western and central parts of the basin drives flow in the shallow and intermediate aquifers toward ground-water discharge areas in the northern, eastern, and southern parts of the basin. A near-surface zone could exist at the top of the shallow aquifer near the central and eastern parts of the basin, where permeable sediments overlie impermeable clay beds. Although little is known about flow in the deep aquifer that underlies the intermediate aquifer, the deep aquifer could be divided into a sedimentary zone underlain by a volcanic zone. Geothermal water probably flows through Mesozoic rocks underlying the entire basin.

\section{Shallow Aquifer}

Ground-water flow and quality in the shallow aquifer are controlled by ground-water/surface-water interactions and evapotranspiration. Analysis of water-quality data discussed previously suggests that application of surface water for irrigation has had relatively little effect on water quality except for possibly decreasing concentrations of sulfate, chloride, and dissolved solids.

The volume of water moving between the surface-water and ground-water systems in the basin is an important component of the water budget for the basin. Water moves between the systems (1) beneath the surface-water distribution system, and (2) beneath irrigated fields. The relative magnitude of the volumes of water interchanged beneath the distribution system compared with that beneath irrigated fields cannot be determined from existing data.
The volume of water that moves between the surface-water distribution system and the shallow aquifer is controlled by (1) the altitude of the water surface in the distribution system relative to the water table of the shallow aquifer, (2) the initial moisture content and hydraulic conductivity of the zone between the bed of the distribution system and the water table, and (3) the frequency and duration of periods of flow through the distribution system.

On the Swingle Bench, near Soda Lake, and in areas that are not irrigated, the seasonal high water table is generally more than $5 \mathrm{ft}$ below land surface and deeper than the surface-water stage in canals and laterals, thus producing a potential for seepage from the land surface to the water table. Near irrigated land, the seasonal high water table is generally less than $5 \mathrm{ft}$ deep. However, seepage loss is high during the first part of the irrigation season when groundwater levels begin to rise in response to seepage from canals and percolation from irrigated fields; groundwater levels reach a maximum near the end of the irrigation season. As saturation increases and groundwater levels rise, the potential for seepage loss decreases and the potential for ground-water discharge to drains increases.

As shown in figure 28, the direction of flow between the surface-water and ground-water systems can change from one side of an irrigated field to the other, with canals providing recharge to the shallow aquifer on one side and drains allowing ground-water discharge from the shallow aquifer on the other side. Because surface water enters the basin from the west and is discharged in the eastern part, the potential is greater for seepage loss in the western part of the basin and for ground-water discharge to drains in the eastern part. But, even near discharge areas, canals can recharge the shallow aquifer (Lico, 1992, p. 8). Also, drains exist in the western part of the basin where the surface-water system can gain flow from the shallow aquifer.

The hydraulic conductivity of canal and drain beds is unknown. Flow velocity in main canals is sufficient to maintain a sand-covered bed, presumably with a relatively high hydraulic conductivity (Michael S. Lico, U.S. Geological Survey, oral commun., 1993). However, near the ends of smaller canals and laterals, and in drains, flow velocities are lower, allowing deposition of fine-grained sediments and accumulation of organic material, which probably decreases the hydraulic conductivity of channel beds.

The hydraulic conductivity of aquifer materials is controlled by their lithology and has been estimated at only a few locations. Relict sand-filled channels of the Carson River probably have higher hydraulic conductivities than the surrounding finer sediments. 
Flow between the surface-water and ground-water systems probably is greatest where unlined canals and drains cross relict sand channels of the Carson River.

Large amounts of water lost from the surfacewater distribution system in dry years (table 2) indicate that the initial moisture content of the beds of canals and laterals can affect the amount of water lost to seepage or wetting of the distribution system. Ponding tests show that the initial wetting of a canal can require large amounts of water (Carol Grenier, Bureau of Reclamation, written commun., 1993). The total amount lost to seepage from the distribution system is a complex function of the seepage rate beneath the canals, the length of time canals and laterals are used, and number of times a canal or lateral is wetted during the irrigation season. The V-, T-, S-, L-, and A-Line Canals and main lateral canals are filled during most of the irrigation season, generally about 216 days (Darren Knuteson, Bureau of Reclamation, written commun., 1993). Small lateral canals carry ground flow for only part of the irrigation season. Thus, the loss through laterals that are not used for the entire irrigation season could be large. Data on the volume of water held in secondary canals and laterals, and the length of time and number of times they are wetted, are needed to estimate the loss in these channels relative to the main canals.

Data on surface-water flow at the boundary of irrigation subdistricts have been collected by the Fallon office of the Bureau of Reclamation (Roger LaSueur, oral commun., 1993). Detailed analysis of these data and continued collection of data on surfacewater flow through the Carson Division could show the location of seepage losses from canals and laterals and ground-water discharge to drains.

The net volume of water percolating to the shallow aquifer beneath irrigated fields is controlled by: (1) the rate of field application, (2) the waterholding capacity and moisture content of soils in the unsaturated zone beneath irrigated fields, (3) the rate of evapotranspiration, and (4) the rate at which ground-water supplies evapotranspiration.

Actual measurements of the volume of surface water applied to irrigated fields and the volume of runoff from fields have been made at relatively few sites. Where measurements have been made, the amount of runoff has been shown to range from 0 to 48 percent of applied water (CH2M Hill, 1973, p. 4-16 to 4-18; Bureau of Reclamation, 1971, p. 9-19). The flow that does not run off irrigated fields can (1) increase soil-moisture storage to supply consumptive use, or (2) recharge the shallow aquifer and supply consumptive use, discharge to drains, or move downgradient where it can supply consumptive use by crops or phreatophytes, or be lost to evaporation from bare soils.

Guitjens and Mahannah (1973, p. 6) and the Bureau of Reclamation (1971) have shown that in some areas application of surface water exceeds crop consumptive use, but in other areas application of surface water is less than crop consumptive use. Where application exceeds consumptive use, the shallow aquifer is recharged. Where application is less than consumptive use, the shallow aquifer could supply the water to meet consumptive-use demands.

The bench/bottom-land designation of the Bureau of Reclamation (1992a) provides an approximation for delineating where irrigation could recharge the shallow aquifer (bench lands) and where the shallow aquifer could supply consumptive use (bottom lands). However, as shown by Guitjens and Mahannah (1973, p. 6) and the Bureau of Reclamation (1971), actual application rates sometimes differ from the designated rates and exceptions to the above approximations are probably numerous. A second approximation available from the bench/bottom-land designation is the water-holding capacity of bottom land. Areas of bottom-land soil with an available water-holding capacity of less than $8 \mathrm{in}$. are more likely to provide recharge to the shallow aquifer than where the available water-holding capacity is greater than 8 in. (fig. 9). Bottom-land soils with greater water-holding capacity are finer and require longer periods of surface-water application causing greater runoff (Bureau of Reclamation, 1971, p. 19). Also on bottom lands, applied water can readily move to the shallow aquifer along relict sand channels of the Carson River (pl. 3). The initial soil-moisture content could also partly control the amount of loss from irrigated fields to the water table.

The rate of evapotranspiration has been accurately measured for maximum crop production at the Newlands Field Laboratory. However, the rate could be highly variable, depending on irrigation practices, soil type, and depth to water on individual fields. The existence and amount of ground-water supply to crop consumptive use is uncertain but probably depends on depth to water and soil properties beneath irrigated fields. Consumptive use could be supplied by ground water recharged upgradient from irrigated fields, over-application of surface water, ground-water recharge during the irrigation season, or some combination of these mechanisms. The mechanism supplying ground water for consumptive use probably 


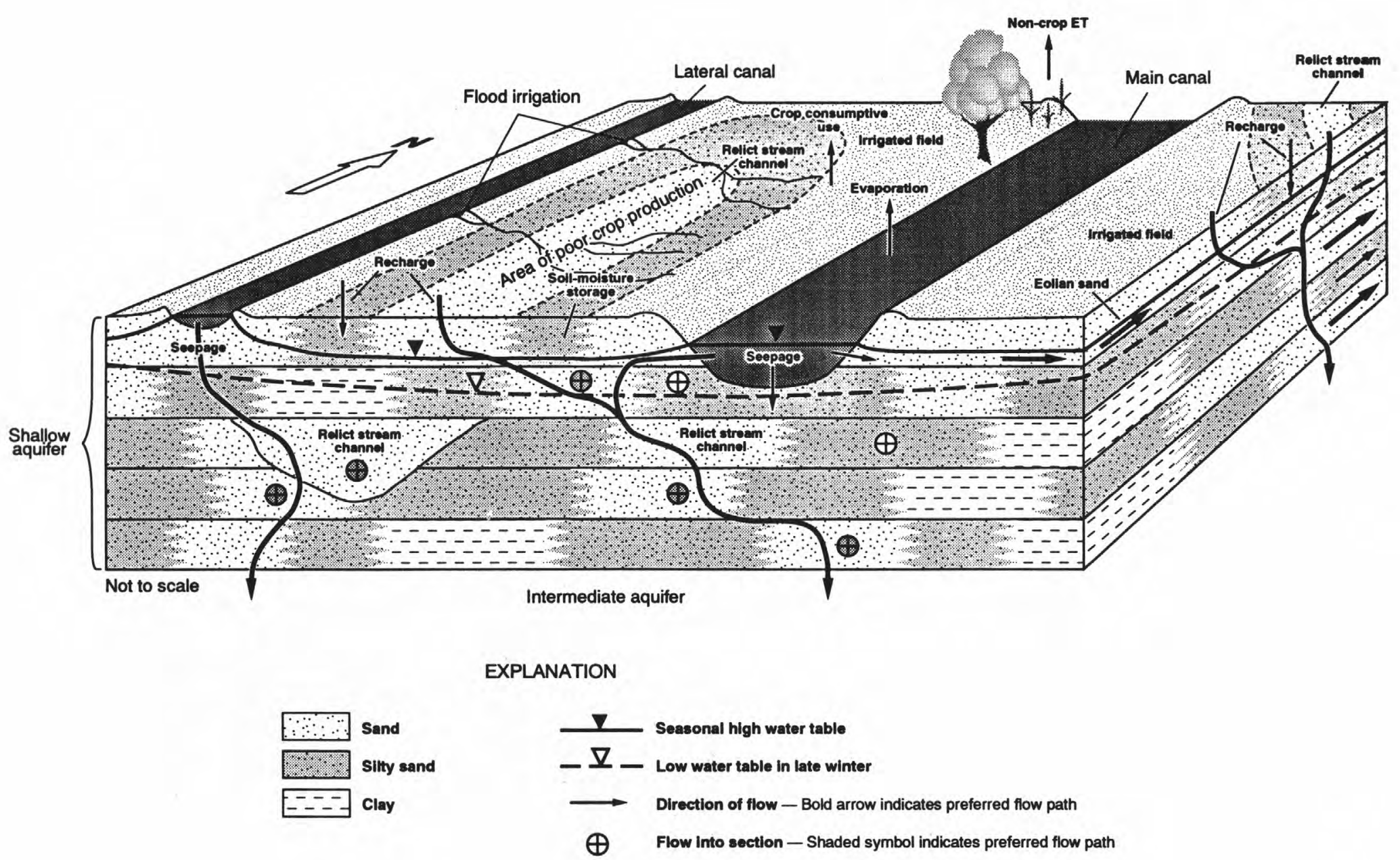

Figure 27. Conceptualized ground-water flow paths in shallow aquifer in western part of Carson Desert. ET, evapotranspiration. 
changes with location in the basin. However, the rate of ground-water supply for consumptive use probably is greater on bottom lands where the water table is shallow than on bench lands.

The net loss of surface water to the shallow aquifer from both the distribution system and irrigated land apparently exceeds the consumptive use by crops and non-crop vegetation. Otherwise, drains would not be required for the Project. Data showing the distribution of this recharge do not exist and processes controlling recharge are a complex function of many factors, as discussed above.

Figure 27 shows hypothetical ground-water flow paths in the western part of the basin. On that side of the basin, sediments forming the shallow aquifer are coarser than those toward the central and eastern parts of the basin. Also, in the western part of the basin the Carson River formed either deltaic or flood-plain sequences, depending on the stage of ancient Lake Lahontan when sediments forming the shallow aquifer were deposited. In both environments, the deposits probably consist of sandy lenses near old channels, grading into beds of silt and clay as distance from the relict channels increases (Reading, 1979, p. 53 and 101). During deposition of the uppermost part of the shallow aquifer, the western part of the basin was higher than the lake levels during deposition of the Fallon Formation and large areas were covered with eolian sand.

Water-level and water-quality data indicate downward flow through the shallow aquifer to the intermediate aquifer on the westernmost side of the basin. Differences in water quality between the shallow and intermediate aquifer suggest the latter is recharged along preferential flow paths either on the western part of the basin or through permeable relict channels of the Carson River near Fallon, and not by diffuse downward flow from the shallow aquifer. Sheets of eolian sand overlie deltaic and fluvial sequences in the western part of the basin forming an upper zone within the shallow aquifer where lateral ground-water flow is possible.

Figure 27 shows hypothesized sand-silt-clay sequences on either side of sand-filled channels. The actual width of the silt deposits is unknown and is no doubt highly variable. Ground water probably moves preferentially along the sand channels in both the horizontal and vertical directions. The vertical component of flow could be greater than the horizontal component. Because clay beds that would inhibit vertical flow are discontinuous, downward flow is possible. The channels mapped by Morrison (1964, p. 11) show that near-surface channels overlie older channels, providing conduits for downward flow.
Where sand channels overlie silt or clay deposits, downward flow is slower, and flow paths could be tortuous. This could partly explain the abrupt variations in water quality noted by previous studies of the shallow aquifer (Glancy, 1986).

In the west-central part of the basin, the potential for flow is downward. Beneath the irrigated land in the center of the basin where Glancy (1986) showed upward potential for flow, vertical gradients are not well known but probably are transitional from downward to upward near ground-water discharge areas. In these transition zones, application of surface water could create a seasonal potential for downward flow.

Saturated sediments of the Fallon Formation near the center of the basin could represent a near-surface zone of the shallow aquifer (fig. 28). Water-level data suggest that a potential exists for downward flow from the shallow to the intermediate aquifer near the center of the basin. However, water-quality data suggest that downward flow is limited. Beneath the near-surface zone and within the shallow aquifer, downward flow could be increasingly inhibited as the content and thickness of clay in the Sehoo Formation increases toward the east. Deposits of both the Fallon Formation and the upper part of the Sehoo Formation represent Glancy's (1986) shallow aquifer. Beds of eolian and river-channel sand in the Fallon Formation could provide preferential flow paths for horizontal flow toward buried river channels and surface-water drains. Ground water can move downward along old channels of the Carson River where the clay is breached.

Near the center of the basin, seepage from canals and from beneath irrigated fields provides recharge to the shallow aquifer. Drains allow ground-water discharge to the surface-water system. Because downward flow is limited, the location of canals and drains and irrigation practices are important in controlling localized ground-water flow. Evapotranspiration and crop consumptive use of ground water increases the concentration of dissolved solids in isolated zones near the surface of the shallow aquifer.

The Fallon Formation is underlain by clay of the Sehoo Formation in the eastern part of the basin (fig. 29). Detailed studies in the area have provided information on lithology to depths of $200 \mathrm{ft}$ below land surface (Morgan, 1982; Tokunga and Benson, 1991; Morrison, 1959). In this part of the basin, ground-water flow is upward from the intermediate to the shallow aquifer and discharges by evapotranspiration or evaporation from bare soil, thus increasing dissolved-solids concentrations. Laterally, continuous confining beds inhibit upward flow except where faulting has offset permeable beds or where clay beds 


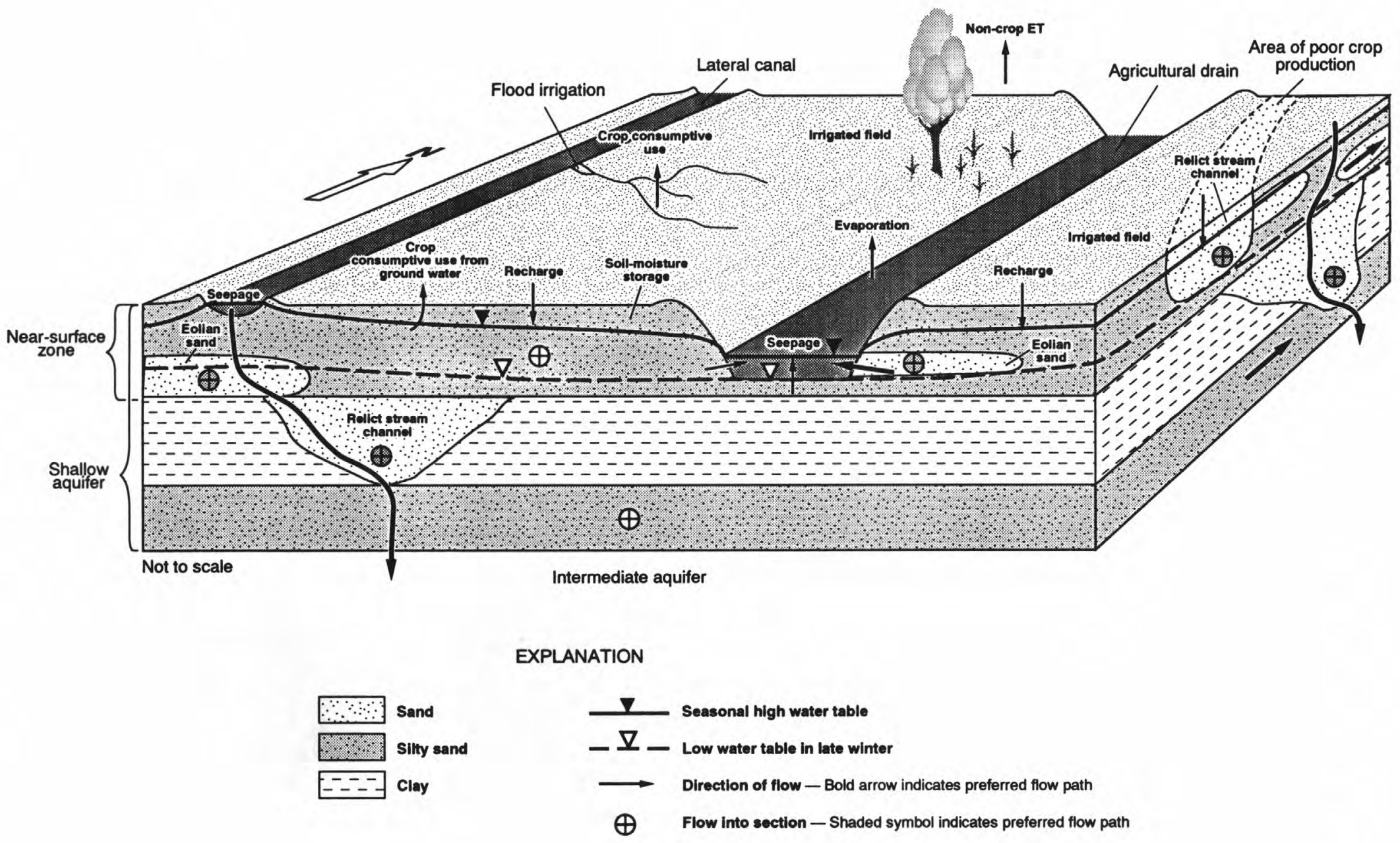

Figure 28. Conceptualized ground-water flow paths in shallow aquifer in central part of Carson Desert. ET, evapotranspiration. 


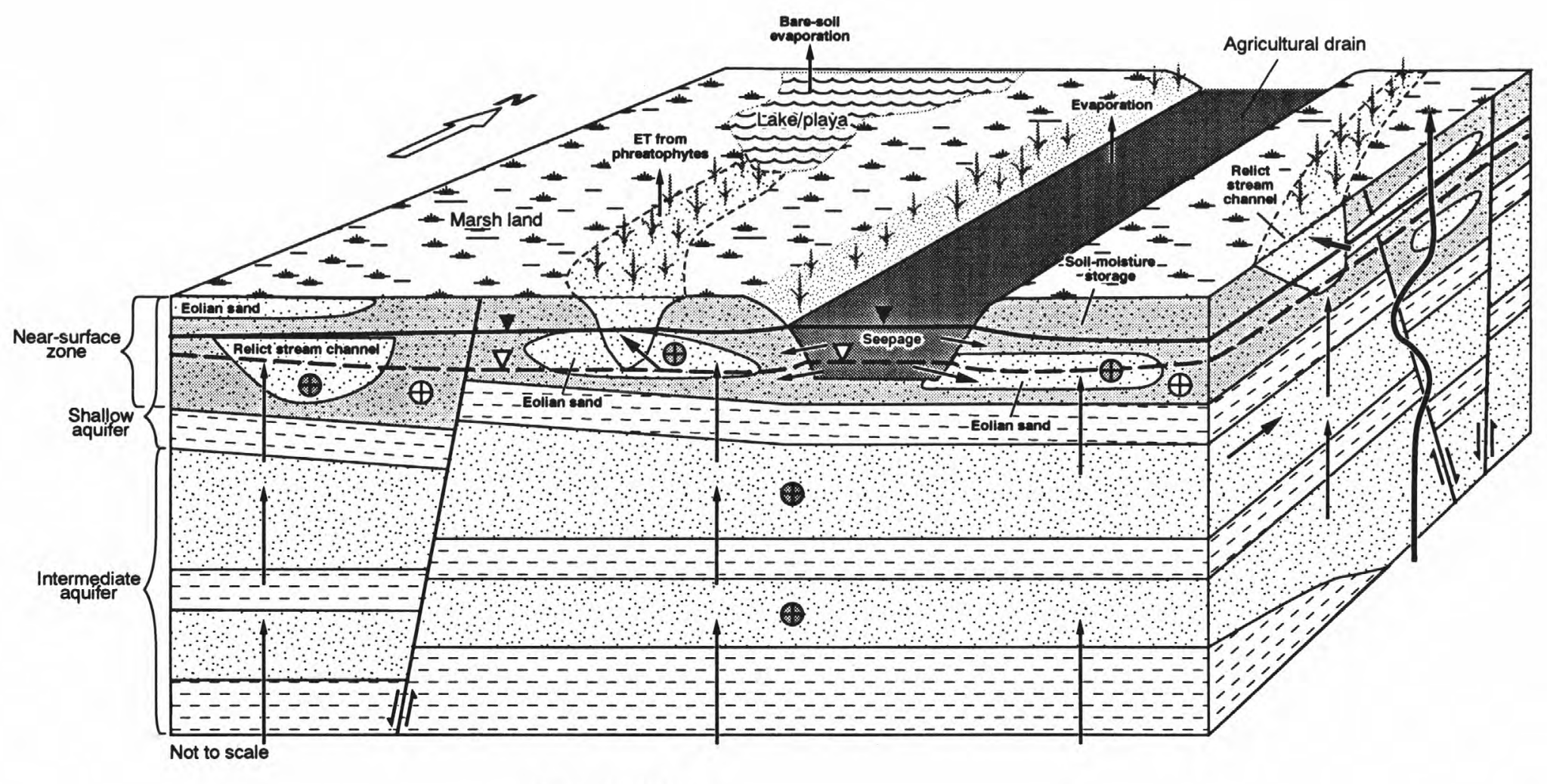

EXPLANATION
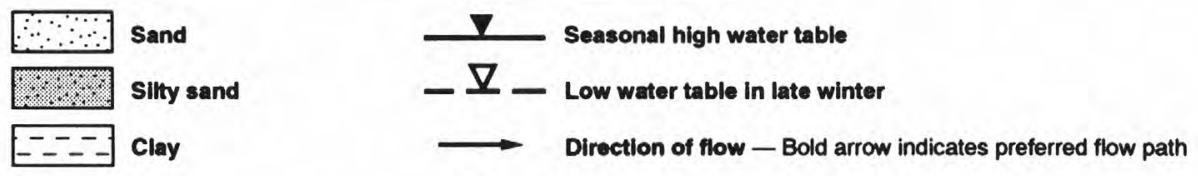

$\bigoplus \quad$ Flow Into section - Shaded symbol indicates preferred flow path

ב Fault - Arrows show direction of relative movement

Figure 29. Conceptualized ground-water flow paths in shallow and intermediate aquifers in eastern part of Carson Desert. 
are breached by relict channels providing an upward flow path. Otherwise, ground water could flow upward, probably at a slow rate by leakage across confining beds. Canals, drains, and lakes generally recharge the shallow aquifer. Eolian sand of the Fallon Formation could provide preferential flow paths for lateral and vertical flow. The vertical component of flow is probably greater than the horizontal component.

\section{Deeper Aquifers}

Much less is known about ground-water flow in the intermediate aquifer. Near the center of the basin, deposits of the Wyemaha Formation probably represent at least the upper part of the intermediate aquifer. West of Soda Lake intermediate aquifer is recharged by the shallow aquifer.

Water-level data show that flow in the intermediate aquifer is from west to east (fig. 26), and the perforated intervals in wells suggest that permeable zones exist from 50 to $200 \mathrm{ft}$ deep west of Fallon and from 80 to $140 \mathrm{ft}$ deep east of Fallon. Few wells penetrate the intermediate aquifer to depths greater than 200 to $300 \mathrm{ft}$ and the distribution of lithology and water quality with depth are largely unknown. The intermediate aquifer provides recharge to the basalt aquifer from the west. East of the basalt aquifer, the intermediate aquifer is recharged by flow out of the basalt aquifer. Near ground-water discharge areas the intermediate aquifer recharges the shallow aquifer.

Little is known about flow paths from the shallow, intermediate, and deep aquifers to the basalt aquifer. Analysis of water-quality data shows that the basalt aquifer is recharged by the shallow, intermediate, and deep aquifers. Additional recharge from the shallow aquifer is probably induced by municipal pumping of the basalt aquifer. However, details of how water moves from the shallow aquifer to the basalt aquifer are not known. Permeable deposits surrounding the basalt aquifer could provide preferential flow paths near the basalt/alluvial contact. Water quality with depth in the basalt aquifer is not known and changes in water quality with depth could have a great effect on continued use of the aquifer as a source of public supply.

Ground-water flow through the deep aquifer is not well understood. Gradients driving flow through this aquifer could be less than those driving the geothermal systems and if the deep aquifer represents ground water in semiconsolidated deposits of Tertiary age, flow through these mostly fine-grained, semiconsolidated sediments is probably very slow. A deep volcanic zone could exist at the base of the deep aquifer. However, the boundary between sedimentary and volcanic zones of the deep aquifer probably is indistinct where sediments and volcanic rocks of Tertiary age are interbedded. Glancy (1986, p. 21) suggests that ground water from the deep aquifer could supply some recharge to the basalt aquifer (fig. 26).

As described by Olmsted and others (1984) and Morgan (1982), the geothermal flow systems circulate ground water from the perimeter of the basin to depths as great as $10,000 \mathrm{ft}$ below land surface, where heating causes the water to rise, contributing as much as 4,000 acre- $\mathrm{ft} / \mathrm{yr}$ to the intermediate and shallow aquifers in the Soda Lake/Upsal Hogback and Stillwater geothermal areas. Geothermal flow near Carson Lake rises from depths of more than $8,000 \mathrm{ft}$ and contributes an unknown amount of flow to the deep aquifer in that area.

\section{Limitations of Conceptual Models}

The accuracy of conceptual models of groundwater flow in the Carson Desert and how representative they might be of actual conditions is limited by processes and controls that remain unknown or poorly understood. The distribution of permeable and impermeable basin-fill sediments, which controls groundwater movement, changes drastically both vertically and horizontally over small distances. Although soil types and geologic units at the surface have been mapped in detail, the distribution of permeable and impermeable sediments at depth and the flowpaths by which ground water moves through the sediments remain unknown for large areas of the Carson Desert.

The shallow depth to water beneath much of the valley floor, combined with the extensive canal and drain system, allows interaction between the groundwater and surface-water systems. Data are lacking on ground-water levels compared with stream stage in canals and drains, and on drain depths that would allow calculation or estimation of where and how much water moves between the ground-water and surface-water systems.

Data are lacking on surface-water flow through the system that would allow calculation or estimation of (1) where seepage is lost from the distribution system, (2) the amount of surface water that is operationally spilled, (3) the amount of water applied to fields that is lost to runoff, percolates to the water table, or is discharged to drains, and (4) how these amounts change with location. The accuracy of data for surface-water flow through the distribution system is uncertain at many sites. Even where measurements 
are most accurate, the large volumes of flow moving through the system cause the uncertainty in measured volumes to partly mask the amounts lost to seepage, evaporation, and evapotranspiration.

Consumptive use by irrigated crops could be supplied in part by ground water. The mechanisms that supply ground water for consumptive use are poorly understood and probably vary with location.

The Carson Desert covers such a large area that small uncertainties in estimates of the rates of groundwater recharge and discharge cause large imbalances in the overall water budget. The mechanisms for recharge to the basalt aquifer are poorly understood because of the lack of data at depth within the aquifer itself and within the shallow, intermediate, and deep aquifers surrounding it.

\section{POTENTIAL EFFECTS OF CHANGES IN AGRICULTURAL WATER USE}

Changes in agricultural water use proposed for the Carson Division of the Newlands Project consist of (1) those mandated by 1988 Operating Criteria and Procedures (OCAP), (2) surface-water flows that will be transferred to wetland areas from irrigated lands by the water-rights acquisition program of the U.S. Fish and Wildlife Service (1992, p. 1), and (3) the potential effects of increasing Project efficiency to 75 percent. Because many of these changes will take place in areas that are not yet delineated, quantitative estimates of the effects on components of the water budget are difficult to ascertain. Also, because many components of the water budget are estimates based on few data, quantitative estimates of the effects in a particular area will be tenuous.

\section{Changes from 1988 Operating Criteria and Procedures}

Details of the 1988 OCAP are listed in the Record of Decision issued by the U.S. Department of Interior (1988). Changes in water-management practices outlined in 1988 OCAP consist of mandatory regulations on water diversion, storage, and delivery, combined with discretionary methods used to achieve a mandated Project efficiency.

Mandatory regulations are (1) an end-of-month storage target for Lahontan Reservoir from January through June of 215,000 acre-ft, and upper and lower limits for Lahontan storage from July through December; (2) the diversion of water from the Truckee River to Lahontan Reservoir only when required to meet the storage targets; (3) delivery of water only to water-righted, irrigable lands; (4) maximum annual headgate deliveries rates of 3.5 acre-ft/acre for bottom land and 4.5 acre-ft/acre for bench land; and (5) a maximum allowable diversion of water for irrigation on the Carson Division (U.S. Department of the Interior, 1988, p. 3-9).

A forecasting technique using predicted Carson River runoff and evaporation and seepage losses from Lahontan Reservoir is to be used to achieve the storage targets and plan diversions from the Truckee River. The volume of water released is determined each year by the amount of eligible land to be irrigated on the Carson Division, water duties allowed on those lands, and a mandated Project efficiency. The final designation of bench and bottom land will be based on bench/bottom-land maps that are subject to approval by the Nevada Federal District court. The Project efficiency was to be increased over a period of 5 years with a target of 68.4 percent for 100 -percent delivery on the project by 1992 . Water conservation methods required to achieve the 68.4-percent efficiency are left to the discretion of local water managers.

Discretionary methods of water conservation include: (1) ordering of water in advance to allow easier adjustment of releases, (2) more frequent adjusting of releases, (3) increasing the accuracy of delivery measurements, (4) changing operation of the regulating reservoirs, (5) shortening the irrigation season, (6) increasing control of the delivery system to eliminate spills and to allow better scheduling and group deliveries, (7) improving delivery control structures, (8) diking regulating reservoirs, (9) lining canals and regulating reservoirs, and (10) re-using drain water blended with prime water for irrigation use (U.S. Department of the Interior, 1988, p. 10).

The potential changes in the surface-water distribution caused by implementing 1988 OCAP regulations have been estimated in the final Environmental Impact Statement produced by the Bureau of Reclamation (1987a), by the Record of Decision from the U.S. Department of the Interior (1988), and by a surface-water routing model developed by Yardas and Robertson (1991).

Headgate deliveries under 1988 OCAP will remain about the same as those prior to 1988 OCAP except for decreases caused by enforcement of water delivery only to water-righted land and changes in bench/bottom-land designation. The major effect of 1988 OCAP is a decrease in outflow from irrigated lands to wetland areas caused by (1) lower storage levels in Lahontan Reservoir, thereby reducing precautionary releases; (2) reduced operational spills from the distribution system; and (3) decreased 
seepage losses that would otherwise supply drain flow to the wetlands. Estimates of the decrease in flow to wetlands range from 24 percent (U.S. Department of the Interior, 1988, p. 20) to 37 percent (Yardas and Robertson, 1991, p. VI-9; David Yardas, Environmental Defense Fund, written commun., 1993) and 55 percent (U.S. Fish and Wildlife Service, 1992, p. 7). Differences in the reported estimates are caused by the use of different assumptions and different irrigated acreage in the calculations.

The effects of mandatory changes on surfacewater flow in the Carson Desert will include (1) a reduction in flow through the Truckee Canal, (2) decreased areas of irrigated land where non-waterrighted lands cease to be irrigated, and (3) decreased amounts of water applied on lands affected by the change in bench/bottom-land designation, and decreased releases from Lahontan Reservoir. The effects of discretionary methods are reduced operational spills from the distribution system and reduced seepage and evaporation losses.

Decreased flow through the Truckee Canal will decrease seepage losses and potential recharge to the Carson Desert. The Bureau of Reclamation (1987a, p. 1-8) estimated that flow in the Truckee Canal near Hazen would decrease by about 40 percent under the final Project efficiencies of the 1988 OCAP. As estimated in the section "Components of Inflow," 4,000 to 20,000 acre- $\mathrm{ft} / \mathrm{yr}$ is lost to seepage along the Truckee Canal in the Carson Desert. If the decrease in canal flow is a function of both decreased flow rate and the length of time flow is present in the canal, seepage losses could be reduced by an amount similar to the decrease in canal flow. Thus, potential recharge to the Carson Desert could decrease from 1,600 to about 8,000 acre- $\mathrm{ft} / \mathrm{yr}$. The reduction in potential recharge along the canal would cause water levels downgradient from the canal to decline, which in turn could reduce consumption of ground water by phreatophytes on the western margin of the Carson Desert, and decrease the size of wetland areas near Mahala Slough and possibly near Massie Slough.

Data compiled by the BOR shows that from 1984 to 1990 , about 56,600 acres on the Carson Division were irrigated, whereas only about 51,000 acres of the irrigated lands held water rights-a difference of about 5,600 acres or about 9 percent of the irrigated land (Bureau of Reclamation, written commun., 1992). The effect of removing 5,600 acres from production would depend greatly on where the irrigated land is located. If the areas not receiving water are isolated and near land where irrigation will continue, seepage losses from nearby land would probably tend to keep water levels from declining where land is removed from production. If large blocks of land will no longer receive irrigation water, water levels could decline, depending on (1) the distance to canals supplying recharge to the shallow aquifer, and (2) the current rate of irrigation application compared to crop consumptive use, as will be discussed in the following section.

About 9,000 acres in the Carson Division will be redesignated from bench land to bottom land (Lyman McConnell, Truckee-Carson Irrigation District, oral commun., 1993). The land affected will receive 1 acre-ft/acre less water annually after the change in designation-a decrease of about 9,000 acre-ft/yr in water applied to irrigated land.

Calculations by the Bureau of Reclamation (1992a, p. 33-35) show that the water table may drop about $1 \mathrm{ft}$ beneath irrigated fields when bottom-land diversion rates are applied to a field compared to bench-land rates. These calculations use the same assumption as Glancy (1986) that specific yield is about 10 percent. Seepage from canals and laterals might be sufficient to maintain water levels in the shallow aquifer when the volume of water applied to irrigated fields decreases.

If water levels in the shallow aquifer decline about $1 \mathrm{ft}$ as a result of the decrease in applied water, and most of the change in bench/bottom-land designation is in the westernmost part of the basin, recharge to the shallow, intermediate, and basalt aquifers could potentially decrease. If the water level in the shallow aquifer uniformly drops about $1 \mathrm{ft}$ and water levels in the intermediate aquifer stay about the same, the vertical gradient would decrease to about $0.08 \mathrm{ft} / \mathrm{ft}$. Applying Darcy's Law to an area of 9,000 acres, and assuming a vertical hydraulic conductivity of $9.84 \times 10^{-3} \mathrm{ft} /$ day, recharge from the shallow to the intermediate aquifer under a gradient of $0.1 \mathrm{ft} / \mathrm{ft}$, as used previously, would be about 3,200 acre-ft/yr. Using the same assumptions and a gradient of 0.08 $\mathrm{ft} / \mathrm{ft}$, recharge would be about 2,600 acre- $\mathrm{ft} / \mathrm{yr}$--a decrease of $600 \mathrm{acre}-\mathrm{ft} / \mathrm{yr}$. This amount is about 2 percent of the total volume estimated for recharge from the shallow to the intermediate aquifer; thus, the effect would probably not be measurable. Eventually, the decrease in recharge to the intermediate aquifer would lower water levels in the intermediate aquifer a small amount, and a new equilibrium would be reached.

Similarly, decreasing recharge to the intermediate aquifer in the western part of the basin could decrease the potential for recharge to the basalt aquifer. However, given the small amount of estimated change in recharge to the intermediate aquifer, the decrease in recharge to the basalt aquifer from the change in bench/bottom-land designation would probably not be measurable. 


\section{Changes From Water-Rights Acquisitions Program and 75-Percent Project Efficiency}

Public Law 101-618 authorizes and directs the USFWS to obtain water rights sufficient to maintain 25,000 acres of wetlands within Lahontan Valley. The law also directs the BOR to study the effects of increasing Newlands Project efficiency to 75 percent. Methods used to achieve 75-percent efficiency include continuation of the discretionary methods used to achieve OCAP efficiency, lining major canals or reservoirs, or lining lateral canals. Because Project efficiency directly affects the amount of water flowing to wetlands, the water-rights acquisition program is based on the amount of flow that might reach the wetlands when the Project achieves 75-percent efficiency. Also, the water-rights acquisition program will continue during the Project efficiency efforts. Thus, the effects of both programs may be cumulative if their goals are achieved.

To maintain 25,000 acres of wetlands in Lahontan Valley under 1988 OCAP, the USFWS estimates that about 125,000 acre-ft/yr will need to be obtained from willing sellers (U.S. Fish and Wildlife Service, 1992, p. 6). This volume of water could be obtained by acquiring water rights from about 28,000 acres of irrigated land, and removing the land from production (Gary Shellhorn, written commun., 1993). Because this water would be delivered directly to wetland areas, the Project efficiency is estimated to increase to about 71 percent without implementation of further efficiency measures. If Project efficiency is increased to 75 percent, about 147,000 acre-ft/yr might be required for the wetlands from about 41,000 acres of irrigated land, depending on whether existing water rights could be transferred (Gary Shellhorn, written commun., 1993). Because the methods used to achieve 75-percent efficiency and the proportion of existing water rights that would be allowed for transfer are not known, the amount of water that needs to be obtained is speculative.

The possible effects on the hydrologic system in the Carson Desert expected under the water-rights acquisition program by the USFWS depend on several factors: (1) the bench/bottom-land designation of acquired water rights, (2) location of land where water rights will be obtained, (3) whether water rights will be obtained from large blocks of land or scattered, individual parcels, (4) changes in the operation of the distribution system necessary to deliver the water to wetland areas, (5) the type of land use that will take place on lands removed from production, and (6) concurrent changes in Project efficiency. All of these factors are unknown.
As discussed previously, hydrologic controls on surface-water and ground-water flow vary greatly from place to place in the Carson Desert. For this reason and reasons listed above, quantitative estimation of the potential effects of changes in water use is difficult and tenuous. The conceptual models for the western, central, and eastern parts of the basin can be used to qualitatively discuss potential effects of greatly decreasing seepage losses from the distribution system and removing large tracts of irrigated land from production.

West of Fallon, losses from the surface-water system recharge the shallow, intermediate, and basalt aquifers. Losses from irrigated lands west of Fallon probably also recharge these aquifers. In this area, the shallow aquifer recharges the intermediate aquifer. Whether the intermediate aquifer recharges the deep aquifer west of Fallon is not known, but all three aquifers are thought to recharge the basalt aquifer. Changes in irrigation practices that would decrease seepage losses or the area of irrigated land west of Fallon have the potential to decrease recharge to the shallow, intermediate, and basalt aquifers in that area.

Near the center of the basin, the surface-water system recharges the shallow aquifer. However, recharge from the shallow aquifer to the intermediate aquifer is limited by clay beds that separate the two aquifers except where the clay beds are breached by relict channels of the Carson River. The shallow and intermediate aquifers recharge the basalt aquifer in the area where a downward potential for flow to the basalt aquifer exists (fig. 12). Changes in irrigation practices that decrease either seepage losses or the amount of irrigated land near the area with a downward flow potential could affect water levels in the shallow and basalt aquifers, but might have less effect on water levels in the intermediate aquifer.

Near the eastern part of the basin, the surfacewater system also recharges the shallow aquifer, and water levels in the shallow aquifer could be affected by decreases in seepage losses or in the area of irrigated land. However, the vertical gradient is upward from the intermediate to the shallow aquifer so that the intermediate and basalt aquifers would probably not be directly affected.

Water levels would decline in response to decreases in seepage from the distribution system caused by canal lining. As shown by Seiler and Allander (1993, p. 15), water levels in the shallow aquifer near the T-Line Canal declined more than $10 \mathrm{ft}$ over a period of about 9 years adjacent to a section of the canal that was lined with concrete. The amount of decrease in recharge to the shallow aquifer from lining individual 
canals is equal to their total seepage rates, which range from 12,000 acre-ft/yr to 19,000 acre-ft/yr for the L-, T-, S-, V-, and A-Line Canals (Bureau of Reclamation, written commun., 1993). The magnitude of water-level decline from a decrease in seepage depends on the specific yield of the adjacent aquifer and on the distance that recharge moves from the canals, which are not known. However, data from Stabler (1904) show that prior to widespread irrigation the depth to water increased to more than $10 \mathrm{ft}$ below land surface within 1 to $2 \mathrm{mi}$ of existing river channels. When major canals are lined within areas taken out of production, water levels could decline similarly to more than $10 \mathrm{ft}$ below land surface within 1 to 2 $\mathrm{mi}$ of the lined canals. Near areas where irrigation continues, lining canals might cause smaller declines because water levels would be maintained if application to nearby fields is in excess of consumptive use.

The relative magnitude of changes caused by lining major canals compared with changes caused by lining only secondary canals and laterals cannot be determined, because the amount of water lost to seepage from the two sources is not known. Also, the relative amounts of recharge to the shallow aquifer from the surface-water distribution system, compared with recharge beneath irrigated fields, are not known. Thus, the relative magnitude of changes caused by canal lining compared with those caused by removing land from production cannot be determined without additional data.

The effects of lining canals and removing land from production could be preferentially propagated downgradient through relict sand channels. Removing the source of seepage to a relict sand channel in upgradient areas could cause water-level declines downgradient along the course of the channel.

Water-level changes in the shallow aquifer from decreasing the area of irrigated land depend on (1) the current net recharge to the shallow aquifer from irrigated fields, and (2) the amount of ground water that currently supplies consumptive use.

If the amount of water applied to irrigated fields exactly equals the amount consumed by crops, the net effect of removing land from production would be zero. However, because seepage from the distribution system supplying the fields might be decreased, water levels beneath fields could decline. The amount of decline depends on the distance from lined and unlined supply canals in the distribution system.

The amount of water applied to irrigated fields compared with the amount consumed by crops has been shown to vary greatly in the Carson Division. The shallow aquifer is recharged beneath irrigated fields where the amount of water applied exceeds consumptive use. If these fields are removed from production, recharge to the shallow aquifer would decrease, and water levels in the shallow aquifer would decline. The amount of decline depends on the distance from lined and unlined supply canals in the distribution system.

Beneath fields where the amount of water applied does not meet consumptive-use demands, the shallow aquifer supplies part of the consumptive-use demand. If these fields are removed from production, discharge from the shallow aquifer would decrease, and water levels in the shallow aquifer could temporarily rise, depending on the distance from drains.

Because the existence of, rates of, and mechanisms for crop consumptive use from ground water are all uncertain, a rise in water levels caused by removing land from production is hypothetical. If vegetation becomes established in areas removed from production, water levels would decline as the established vegetation draws water from the shallow water table. Declining water levels in the shallow aquifer could cause an increase in the drawdown in pumped wells. Rising water levels in the shallow aquifer would increase flow to existing drains.

The effect of removing land from irrigation also depends on the mechanism that supplies water from the shallow aquifer for crop consumptive use. If ground water is supplied to consumptive use by flow from upgradient areas, changes in the distribution of irrigation could cause ground-water levels to temporarily rise in areas removed from production, or decline in areas downgradient from the change, depending upon the historical rate of application compared with consumptive use. The changes in water level would tend to decrease with time as the ground-water system reaches a new equilibrium. If ground water is supplied to consumptive use from water applied to fields early in the irrigation season, change in the distribution of irrigation might have little effect on water levels downgradient from areas of change. However, changes in irrigation practices early in the season that decrease the amount of water applied to fields could decrease the amount of ground water available for consumptive use later in the season and" cause net water-level declines in areas of change.

Estimates listed in the section "Water Budget for Carson Desert" indicate that recharge to the shallow aquifer from the surface-water system could range from 50,000 to 100,000 acre- $\mathrm{ft} / \mathrm{yr}$. A hypothetical example can be used to estimate the magnitude of water level declines that might be expected from changes in water use. If (1) the amount of seepage 
from the distribution system and recharge from irrigated land is reduced in direct proportion to the amount of land removed from production, and (2) the reduction is 50 percent, recharge to the shallow aquifer could decrease by 25,000 to 50,000 acre-ft/yr beneath about 30,000 acres of land removed from production. If specific yield in the shallow aquifer is 10 percent, water levels in the shallow aquifer could decline from about $8 \mathrm{ft}$ to as much as $17 \mathrm{ft}$. If the average specific yield in the shallow aquifer is closer to 20 percent, the estimate of water-level declines would range from about 4 to $8 \mathrm{ft}$.

Application of the Thiem equation can provide an estimate of the effect of water-level declines on pumping wells. The Thiem equation can be used to determine the head at any two points on the cone of depression around a pumping well (Lohman, 1972, p. 11). In thin, unconfined aquifers where the drawdown is a large part of the aquifer thickness, Jacob (1963) showed how to correct drawdown to what would have occurred had there been no reduction in aquifer thickness caused by pumping. Trescott and others (1976, p. 10, eq. 16) presented a version of this equation written in terms of aquifer thickness as:

$$
H_{\mathrm{w}}=\sqrt{H_{r}^{2}-Q_{\frac{\mathrm{w}}{\pi \mathrm{K}}} \ln \frac{R_{r}}{R_{\mathrm{w}}}}
$$

where $H_{\mathrm{w}}=$ saturated thickness at radius of pumped well, $\mathrm{R}_{\mathrm{w}}$;

$H_{r}=$ saturated thickness of aquifer at radius of $R_{r}$;

$Q_{\mathrm{w}}=$ pumping rate of well;

$K=$ horizontal hydraulic conductivity of aquifer;

$R_{r}=$ radius to point on cone of depression that is far enough away from pumped well for drawdown to be small compared with $H_{r}$ (examples used in this report meet this criterion); and

$R_{\mathrm{W}}=$ radius of pumped well.

If $H_{r}$ represents the general saturated thickness of the aquifer prior to pumping and the drawdown at radius $R_{r}$ is considered small enough compared to $H_{r}$ to be negligible, this equation can be used to calculate an estimate of the saturated thickness of the aquifer at the pumped well. Included in this equation are assumptions that (1) the well fully penetrates the aquifer and (2) there is no head loss associated with well construction.
The equation can be applied to a hypothetical example near the center of the Carson Desert where wells are pumping from a relatively thin near-surface zone overlying a clay bed in the shallow aquifer. Using values of:

$$
\begin{aligned}
& H_{r}=30 \mathrm{ft}, \\
& Q_{\mathrm{w}}=20 \mathrm{gal} / \min \left(3,850 \mathrm{ft}^{3} / \mathrm{d}\right), \\
& K=40 \mathrm{ft} / \mathrm{d}, \\
& R_{r}=300 \mathrm{ft}, \text { and } \\
& R_{\mathrm{w}}=0.25 \mathrm{ft},
\end{aligned}
$$

the saturated thickness at the pumped well is about $26 \mathrm{ft}$. If water levels decline uniformly by $5 \mathrm{ft}$, the thickness of the aquifer $H_{r}$ would decrease to $25 \mathrm{ft}$. The saturated thickness at the pumped well calculated using an $H_{r}$ of $25 \mathrm{ft}$ is about $20 \mathrm{ft}$, a difference of about $6 \mathrm{ft}$. The resulting value for aquifer thickness at the pumped well depends mostly on the values used for pumping rate, hydraulic conductivity, and aquifer thickness. Hydraulic conductivity and aquifer thickness are not well known in most parts of the Carson Desert. Because $R_{r} / R_{\mathrm{W}}$ is a natural-logarithm function, changes in either $R_{r}$ or $R_{\mathrm{w}}$ values do not greatly affect results of the calculation.

Using the values listed above for $Q_{\mathrm{w}}, K, R_{r}$, and $R_{\mathrm{W}}$, the following values for saturated thickness at the pumped well $\left(H_{\mathrm{w}}\right)$, rounded to the nearest foot, are obtained for the following aquifer thicknesses $\left(H_{r}\right)$ shown:

when $H_{r}=20 \mathrm{ft}, H_{\mathrm{w}}=14 \mathrm{ft}$; when $H_{r}=15 \mathrm{ft}, H_{\mathrm{w}}=3 \mathrm{ft}$; and when $H_{r}=14 \mathrm{ft}, H_{\mathrm{w}}=0$.

The calculations show that the effect of declining water levels on drawdown in pumped wells increases as the thickness of the near-surface zone decreases. For the values used in the calculations above, when $H_{r}$ approaches $14 \mathrm{ft}, H_{\mathrm{w}}$ decreases to zero. However, if pumped wells do not completely penetrate the nearsurface zone or have loss associated with improper well construction, drawdown in these wells would be greater than that calculated by the equation given above. Also, because the values used in the calculations are assumptions based on sparse data and probably vary greatly from place to place in the Carson Desert, the resulting values for $H_{\mathrm{w}}$ are only hypothetical. However, a generalization can be made. Where the near-surface zone in the shallow aquifer is thickest, wells that are properly constructed and that fully penetrate the entire thickness of the near-surface zone might not be greatly affected by water-level 
declines in the shallow aquifer. Where the nearsurface zone is thin, shallow or poorly constructed pumped wells could go dry.

Water-quality data indicate that irrigation has resulted in decreased concentrations of sulfate, chloride, and dissolved solids beneath irrigated lands. Thus, removing land from irrigation could cause a change in the concentration of these constituents. However, additional water-quality data showing the change in water quality from changes in irrigation practices could determine if concentrations would increase or decrease. Additional water-quality data in affected areas are needed to determine whether changes in irrigation practices would effect water quality.

\section{SUGGESTIONS FOR FUTURE STUDY}

Present understanding of existing water resources, movement of water, and potential effects of changes in water use in the Carson Desert could be improved by detailed study. References to additional data that would improve understanding of these factors have been made throughout this report. The following sections present suggestions for additional study.

\section{Existing Water Resources and Ground- Water Movement}

- The intermediate aquifer is potentially the largest source of potable water in the Carson Desert. The vertical and lateral extent of potable ground water in the intermediate aquifer remain unknown. A program of exploratory drilling would help refine the limits of this resource.

- Mechanisms for recharge to the basalt aquifer and the volume of potable water available in the basalt aquifer remain poorly understood, because available data are limited to the uppermost part of the aquifer. In the basalt aquifer and in adjacent aquifers both above and below the basalt, more data on water levels and water quality could allow determination of the volume of potable water available in the basalt and the mechanisms for recharge.

- Continued measurements of water levels in the shallow, intermediate, and basalt aquifers would show how gradients driving flow between the aquifers have changed from those measured by Glancy (1986) in the mid-1970's. Additional measurements of the vertical gradients between the shallow, intermediate, and basalt aquifers west of Fallon, and between the shallow and intermediate aquifers east of Fallon, would more precisely delineate flow paths between the aquifers.

- Additional water-quality data can be used to show the locations of recharge and discharge between aquifers in the Carson Desert. The area southeast of Soda Lake is one of transition for water quality in the intermediate aquifer. More detailed water-quality data in this area would increase the understanding of recharge flow paths from the shallow to the intermediate aquifer and, in turn, from the intermediate to the basalt aquifer. Data on tritium activity and stable-isotope composition for water in the shallow, intermediate, and basalt aquifers have shown that these constituents could be used to trace ground-water flow between the three aquifers. A sampling program that targets relict channels of the Carson River could provide data to aid analysis of how water moves through these permeable zones that are probably preferential ground-water flow paths.

- The movement of ground water in the shallow aquifer and between the shallow and intermediate aquifers is controlled by changes in lithology in the upper $50 \mathrm{ft}$ of Quaternary basin-fill deposits. Detailed analysis of all available lithologic logs would allow further delineation of areas with high and low potential for vertical flow, and delineation of areas where changes in water use might have the greatest effects.

- Detailed study of the rates of recharge to and discharge from the basin would allow refinement of the overall water budget of the basin. Topics for study include more closely measuring the rate of recharge from precipitation in areas covered with sand dunes and where the depth to water is shallow, the rate of discharge from playas, and the rate of discharge by phreatophytes and other non-crop vegetation in the Carson Desert.

- Further refinement of estimates for water-budget components could be made by using remote imagery. Classification of remote images would provide more accurate estimates for the variation of areas covered by sand dunes, playas, openwater bodies, areas where the water table is shallow, and the distribution and density of phreatophytes in the basin and non-crop vegetation near irrigated lands. 


\section{Potential Effects of Changes in Water Use}

- Accurate maps showing the location of canals, laterals, and drains combined with data on the direction and depth of flow, wetted perimeter, and altitude of the channel bed would permit the design of detailed data-collection networks.

- A compilation of monthly surface-water flow data for the longest period of record available would allow a detailed analysis of flow through the distribution system and provide the basis to design a data-collection program.

- Accurate measurements of surface-water application, runoff, and crop consumptive use on irrigated fields throughout the Carson Division could allow estimation of the effects of changes in water use.

- Detailed measurements of flow at numerous points along canals, laterals, and drains would allow closer estimation of the magnitude of seepage losses, the amount of operational spill, and the ground-water contribution to drain flow. Targeting locations where canals and drains intersect relict channels of the Carson River for measurements would show their effect on seepage rates. Synoptic surface-water measurements made along three to four arcs of increasing radius perpendicular to the direction of surface-water flow could show the amount of loss as flow moves from west to east across the basin. Test releases during the non-irrigation season would allow more accurate measurements of seepage from the distribution system.

- Establishing a surveyed network of sites where the water-level altitude in the shallow aquifer can be compared with the altitude of stream stage in canals, laterals, and drains could show the locations of recharge to and discharge from the shallow aquifer.

- Estimates of recharge and discharge from observed water-level changes and estimates of the potential changes in water levels that might accompany changes in water use require knowledge of the range and distribution of specific yield. After analysis of existing lithologic data, a program of exploratory drilling would provide additional lithologic data, samples of aquifer material that could be tested to determine the distribution of specific yield, and monitoring wells.

- As the processes of increasing Project efficiency and transferring water rights to wetlands proceed, the opportunity exists for directly monitoring the effects on the hydrologic system.
This would allow closer evaluation of continued changes in water use in the Carson Desert. Monitoring surface-water quality and flow and ground-water quality and levels at increasing distances from (1) reservoirs removed from use, (2) canals that are lined, (3) drains taken out of operation, or (4) land removed from production would document the effects of such future activity. Water-quality data collected using consistent, reproducible sampling and analytical methods are essential for comparative analyses.

\section{SUMMARY AND CONCLUSIONS}

Operating Criteria and Procedures (OCAP) established for the Newlands Project in 1988 and the directives of Public Law 101-618 could result in reduction of water used for agriculture by about 125,000 acre-ft/yr. Such a reduction could potentially affect ground-water supplies in the Carson Desert. Existing studies were compiled to determine: (1) how the aquifer systems are recharged, (2) what controls ground-water flow through the systems, (3) how changes in water use might affect the systems, and (4) data collection and studies that would refine estimates of the potential effects.

Rocks of Mesozoic age exposed in the eastern part of the Carson Desert underlie the valley floor at depths as great as $12,000 \mathrm{ft}$. Thick sequences of volcanic flows, tuffs, and sedimentary rocks overlie the Mesozoic basement beneath the valley floor. Volcanic rocks of Quaternary age form isolated cones exposed at land surface. In the subsurface, basalt of Rattlesnake Hill extends over $30 \mathrm{mi}^{2}$ and is enclosed by basin-fill deposits.

Sediments of Quaternary age are important aquifers in the Carson Desert, and differences in their lithology provide an important control on groundwater flow in the basin. Depositional environments in the basin during the Quaternary Period were controlled by dramatic changes in the level of ancient Lake Lahontan, from deep-lake intervals to intervals of complete desiccation. Inflow of the Carson River deposited coarse-grained sediments in the western part of the basin, and thick clay beds were formed beneath lakes in the center and in the eastern part of the basin. Changes in lake levels produced laterally extensive beds of beach and eolian sand, interbedded with clay beds near the center of the basin and deltaic deposits in the western part. Relict sand-filled channels of the Carson River exist over much of the western and central parts of the basin. 
Lahontan Reservoir stores flow from the mainstem of the Carson River and from the Truckee River through the Truckee Canal. Flow released from the reservoir is distributed through about $340 \mathrm{mi}$ of canals and laterals to an estimated 1,500 farm headgates. About $350 \mathrm{mi}$ of open drains direct return flow and shallow ground water to wetlands covering about 45,000 acres in wet years and about 7,000 acres in dry years.

Uncertainties in the estimates of surface-water flow volumes through the distribution system do not allow precise determination of the fate of surface water released from Lahontan Reservoir. Historically, about 370,000 acre-ft/yr has been released from the reservoir. Of that volume, about $200,000 \mathrm{acre}-\mathrm{ft} / \mathrm{yr}$ has been lost to operational spill, seepage to shallow ground water, and evaporation from the distribution system before delivery of about 170,000 acre- $\mathrm{ft} / \mathrm{yr}$ to farm headgates. The on-farm loss of the delivered water is poorly known but could be about 60,000 acre-ft/yr. Consumptive use by crops and non-crop vegetation on irrigated land is about 180,000 acre$\mathrm{ft} / \mathrm{yr}$, and precipitation and shallow ground water could supply about 20,000 acre-ft/yr and 50,000 acre$\mathrm{ft} / \mathrm{yr}$, respectively, to consumptive use. Outflow from irrigated land of 170,000 to 190,000 acre-ft/yr supplies flow to wetland areas and the Carson Sink, where more than 210,000 acre-ft/yr is lost to evaporation and evapotranspiration.

Annual variations in surface-water flow show linear relations for years when releases from Lahontan Reservoir were less than about 350,000 acre-ft/yr between: (1) headgate delivery, losses above farm headgates, and total loss from irrigated land, compared with releases from Lahontan, and (2) losses above farm headgates, compared with outflow from irrigated lands. For years when releases are greater than 350,000 acre-ft, a large part of the water flows directly to wetlands at or near Carson Lake, Stillwater WMA, and the Carson Sink during winter and early spring. Because outflow from irrigated land is a mixture of operational spill from the distribution system, on-farm losses, and ground-water seepage to drains, conclusions about the magnitude of these losses compared with releases from the reservoir are limited. Headgate deliveries and the amount lost above farm headgates vary with precipitation in Fallon, implying that soil-moisture conditions have some control on seepage losses and on-farm use.

Surface water generally has low dissolved-solids concentrations except in drains near areas of groundwater discharge where dissolved-solids concentrations are as much as nine times greater than those found in Lahontan Reservoir. The concentrations range from 2,000 $\mathrm{mg} / \mathrm{L}$ near Carson Lake to as much as
$120,000 \mathrm{mg} / \mathrm{L}$ near Stillwater WMA. Near areas of ground-water discharge, drain flow is representative of water quality in the adjacent shallow aquifer during the non-irrigation season. The total dissolved-solids load to Stillwater WMA in 1989 was about 122 ton/d.

Ground-water flow in the Carson Desert is found mainly in unconsolidated sediments and volcanic rocks beneath the floor of the valley. Mesozoic rocks in the Stillwater and Sand Springs Ranges form a barrier to most ground-water flow to the east and below the unconsolidated and volcanic deposits of the basin. Volcanic rocks forming the topographic divides on the south and west sides of the basin could be permeable to ground-water flow. Water in basinfill sediments ranges in depth from more than $400 \mathrm{ft}$ near mountain blocks, to less than $10 \mathrm{ft}$ below irrigated land.

Surface-water irrigation has caused a rise in water levels beneath irrigated land over large areas of the Carson Desert. The result of this rise in the water table was an increase in the gradient driving flow toward the north, east, and south from the point where the Carson River enters the basin.

Glancy (1986) defined a basalt aquifer and three alluvial aquifers-shallow, intermediate, and deep-on the basis of water quality and depth. Other studies describe aquifer systems in slightly different ways, but Glancy's definitions are common to most.

The shallow aquifer extends to a depth of $50 \mathrm{ft}$ below land surface and is characterized by hard water and abrupt changes in lithology and water quality in both the horizontal and vertical directions. Near the center of the basin, sediments of the Fallon Formation and the upper part of Sehoo Formation form the shallow aquifer. A near-surface zone could exist in the upper part of Glancy's shallow aquifer where vertical flow is impeded by clay beds of the Sehoo Formation. Water levels in the shallow aquifer show that flow moves from west to east, although locally, flow direction in the shallow aquifer is highly variable. Measurements in 1992 show that declines caused by drought conditions prior to 1992 were generally less than $1 \mathrm{ft}$ and more than $2 \mathrm{ft}$ at one location compared with water levels in the mid1970 's, which also were drought years. Water levels in 1992 declined from $1 \mathrm{ft}$ to slightly more than $4 \mathrm{ft}$ compared with those measured in the mid-1980's, which were extremely wet years.

Water-level fluctuations show that the shallow aquifer is recharged by surface-water seepage during the irrigation season. Drains provide a conduit for discharge from the shallow aquifer to the surfacewater system. Major components of discharge from the shallow aquifer are evapotranspiration and baresoil evaporation from playas. Water-level changes in 
the shallow aquifer have been noted after changes were made in the irrigation system. Ground water in the shallow aquifer has a median $\mathrm{pH}$ of 7.4 , is hard, and has dissolved-solids concentrations ranging from less than $100 \mathrm{mg} / \mathrm{L}$ near recharge areas to more than $100,000 \mathrm{mg} / \mathrm{L}$ near ground-water discharge areas.

The intermediate aquifer could be the largest resource of potable ground water in the Carson Desert. It extends from $50 \mathrm{ft}$ below land surface to 500 to $1,000 \mathrm{ft}$ in depth and is characterized by generally soft, fresh water. Near the center of the basin, the Wyemaha Formation represents at least the upper part of the intermediate aquifer. The base of the intermediate aquifer, as defined by water quality, could be deeper than $1,000 \mathrm{ft}$ and might correspond with the boundary between basin-fill deposits of Quaternary and Tertiary age. Prior to the mid-1970's, it was not recognized that the intermediate aquifer contained potable water. Since 1985 , more than 500 wells have been drilled to depths of 50 to $200 \mathrm{ft}$ west of Fallon along the channel of the Carson River and 80 to $140 \mathrm{ft}$ near the center of the basin, suggesting that permeable zones exist at these depths.

Water-level altitudes in the intermediate aquifer have the same general configuration as those in the shallow aquifer. However, the water-level gradient is not as steep as in the shallow aquifer, creating a potential for downward flow from the shallow to the intermediate aquifer west of Fallon, and a potential for upward flow from the intermediate to the shallow aquifer in the remainder of the basin. Vertical gradients between the shallow and intermediate aquifers and within the intermediate aquifer increase during wet years, decrease during dry years, and can change in magnitude and direction with depth at some locations. Ground water in the intermediate aquifer is hundreds of years old west of Fallon, thousands of years old near Fallon, and several thousand years old more than about $5 \mathrm{mi}$ northeast from Fallon. The intermediate aquifer is also distinguished from the shallow aquifer by a median $\mathrm{pH}$ of 9.1 and generally soft water, although hard water is found on the western margin of the basin. The concentration of dissolved solids ranges from about 100 to $1,000 \mathrm{mg} / \mathrm{L}$ within 5 to $12 \mathrm{mi}$ of Fallon and increases to as much as $8,000 \mathrm{mg} / \mathrm{L}$ near Stillwater WMA.

The deep aquifer as defined by Glancy (1986) is characterized by water containing high dissolvedsolids concentrations and could range in depth from 1,000 to greater than $8,000 \mathrm{ft}$. The deep aquifer may consist of a deep sedimentary zone and a deeper volcanic zone. Dissolved-solids concentrations could range from 1,000 to greater than $5,000 \mathrm{mg} / \mathrm{L}$. Very little is known about the deep aquifer.
The basalt aquifer is the main source of supply for public use in Fallon and at the Naval Air Station. The aquifer is a mushroom-shaped volcanic plug enclosed by basin-fill sediments. The basalt is exposed at Rattlesnake Hill and encountered nearby at depths from 200 to $600 \mathrm{ft}$. The aquifer has a high transmissivity and water levels indicate a slight gradient to the northeast. Water levels in the shallow and intermediate aquifers are $30 \mathrm{ft}$ above and $20 \mathrm{ft}$ below those of the basalt aquifer in the southwestern and northeastern parts of its extent, respectively. Present withdrawals from the basalt aquifer total about 3,000 acre- $\mathrm{ft} / \mathrm{yr}$, causing drawdown of about 10 feet compared with reported pre-pumping levels. Pumping has been shown to induce recharge from the shallow aquifer, and the intermediate and deep aquifers are thought to also recharge the basalt aquifer.

Water quality of the basalt aquifer varies over a much narrower range than the alluvial aquifers. It has a median $\mathrm{pH}$ of 9.3 , is soft, and has dissolved-solids concentrations from 300 to $700 \mathrm{mg} / \mathrm{L}$. The carbon- 14 age of the water ranges from about 1,000 to 4,000 years near the southwestern part of its extent, and as much as 8,000 years near the northeastern part of its extent. Interpretation of water-quality data shows an increasing trend of chloride and arsenic concentrations and decreasing calcium concentrations from 1962 to 1992 in the basalt aquifer. The source of chloride and arsenic could be inflow from the surrounding aquifers or from deeper in the basalt aquifer itself.

Geothermal aquifer systems have been described in the Soda Lake/Upsal Hogback, Stillwater, Carson Lake, and Salt Wells areas. Both the Soda Lake/Upsal Hogback and Stillwater geothermal systems are thought to be recharged by shallow ground water from within the basin that has circulated to depths greater than $10,000 \mathrm{ft}$. The geothermal fluids rise into the shallow and intermediate aquifers along faults. Geothermal flow near Carson Lake rises from depths of over $8,000 \mathrm{ft}$ and contributes an unknown amount of flow to the deep and intermediate aquifers in that area. Little is known about the geothermal system near Salt Wells. Geothermal water at Soda Lakes/Upsal Hogback and Stillwater areas has dissolved-solids concentrations ranging from 4,000 to $6,000 \mathrm{mg} / \mathrm{L}$ and is distinguished from non-thermal water by higher concentrations of dissolved silica. Upflow from geothermal aquifers is estimated to be about 4,000 acre-ft/yr.

Ground-water quality in the Carson Desert varies greatly from a dilute calcium bicarbonate type in the western part, to a saline sodium chloride type near ground-water discharge areas. Rising water levels caused by irrigation have probably mobilized ions 
adsorbed on sediment grains in previously unsaturated sediments, causing increased concentrations of dissolved iron, manganese, and uranium. Drinking-water standards for the State of Nevada are exceeded as follows: for arsenic, almost everywhere in the basin; for sulfate, chloride, dissolved solids, and fluoride, near Upsal Hogback, Stillwater WMA, Carson Lake (downgradient along an arc about 9 to $10 \mathrm{mi}$ from Fallon); for iron, generally west of U.S. Route 95; and for manganese, at many locations throughout the Carson Desert.

Interpretation of water-quality data suggests that irrigation may have caused a decrease in sulfate, chloride, and dissolved-solids concentrations. Concentrations of arsenic are greater in the upper $20 \mathrm{ft}$ than from 20 to $50 \mathrm{ft}$ below land surface and are greater in nonpermeable than permeable deposits. Data are not available that would allow determination of whether concentrations of dissolved constituents would increase or decrease from a change in the amount of water applied for irrigation.

The water budget calculated for the basin does not balance because of uncertainties in estimated rates for components of inflow and outflow and should be considered preliminary. Inflow consists of surface water released from Lahontan Reservoir; seepage from the Truckee Canal and irrigated land along the Truckee Canal; recharge from precipitation on surrounding mountain blocks, in areas of sand dunes, and areas of where depth to water is shallow; and groundwater and surface-water inflow from adjacent basins. Outflow from the basin consists of evaporation and evapotranspiration from open-water bodies, crops, and non-crop vegetation on irrigated lands; open-water bodies and vegetation near wetland areas; discharging playas; and phreatophytes outside irrigated land and wetland areas. Estimates for inflow range from 400,000 to 420,000 acre-ft/yr, whereas estimates for outflow range from 630,000 to $680,000 \mathrm{acre}-\mathrm{ft} / \mathrm{yr}$.

Estimates of inflow to and outflow from the surface-water system and the shallow aquifer and between individual aquifers show that inflow to and outflow from the shallow aquifer could be greater than 120,000 acre-ft/yr with most taking place in the vertical direction. Flow through the basalt aquifer is estimated to be about 4,000 acre-ft/yr, again mostly in the vertical direction. Flow through the intermediate aquifer could be from 25,000 to over 30,000 acre-ft/yr with a large component of horizontal flow. These estimates were determined to obtain an approximate idea of the amount of flow that could take place through the aquifers and could be greater or less by an order of magnitude or more. Upflow from geothermal aquifers is estimated to be about 4,000 acre-ft/yr.
Conceptual models of how water moves through the Carson Desert show idealized and hypothetical directions of flow based on the existing understanding of recharge mechanisms and flow paths through the system. Although flow between the surface-water and ground-water systems takes place in all parts of the basin, the potential is probably greater for recharge to the shallow aquifer from surface-water sources in the western part of the basin, and discharge from the shallow aquifer to surface-water sources in the eastern part of the basin. Recharge in the western and central parts of the basin drives flow toward the northern, eastern, and southern parts of the basin, where ground-water discharges. The distribution of lithology in the shallow, intermediate, and deep aquifers controls the movement of ground water.

Because the Carson River entered the basin from the west during deposition of Quaternary basin fill, sediments are coarser there and decrease in grain size and permeability toward the eastern half of the basin. West of Fallon, the shallow aquifer supplies recharge to the intermediate aquifer. In this area, permeable sediments in the upper $50 \mathrm{ft}$ of basin-fill deposits allow lateral flow in the shallow aquifer and downward flow from the shallow to the intermediate aquifer. Near the center of the basin, where the potential for ground-water flow is downward, recharge from the shallow aquifer to the intermediate aquifer could be limited by the presence of laterally extensive clay beds of the Sehoo Formation, except where they are breached by relict channels of the Carson River. In the eastern part of the basin, the vertical gradient is upward, but clay beds of the Sehoo Formation restrict vertical flow except where they are breached by relict channels. Extensive sand beds of the Fallon Formation allow lateral flow over most of the basin to and from points of recharge and discharge and vertical flow.

Deposits of the Wyemaha Formation form at least the upper part of the intermediate aquifer near the center of the basin. The intermediate aquifer provides recharge to the basalt aquifer from the west, and east of the basalt aquifer the intermediate aquifer is recharged by flow out of the basalt. Near groundwater discharge areas, the intermediate aquifer recharges the shallow aquifer.

Little is known about flow paths from the shallow, intermediate, and deep aquifers to the basalt aquifer. However, interpretation of water-quality data shows that the basalt aquifer is recharged by all three. Recharge from the shallow aquifer probably is induced by municipal pumping of the basalt aquifer. Although details of how water moves from the surface-water system to the shallow, intermediate, and 
deep aquifers and then to the basalt aquifer are not known. The direction and volume of ground-water flow through the deep aquifer are largely unknown.

Conceptual models of the ground-water systems in the Carson Desert are limited by the lack of detailed analysis of changes in lithology in basin-fill deposits of Quaternary age, data showing where and how much water moves between the surface-water and ground-water systems, and uncertainties in estimates for rates of recharge and discharge.

Potential changes in water use in the Carson Division include those from 1988 OCAP and Public Law 101-618. Changes from 1988 OCAP include mandatory regulations and discretionary methods to increase Project efficiency. These regulations would decrease flow through the Truckee Canal, decrease releases from Lahontan Reservoir, reduce operational spills and seepage, reduce evaporation losses from the distribution system, and decrease the area of irrigated land and amount of water applied for irrigation. The effects of the changes include reduction of (1) flow to wetland areas by as much as 55 percent; (2) recharge to the Carson Desert from Truckee Canal seepage by as much as 8,000 acre- $\mathrm{ft} / \mathrm{yr}$; and (3) recharge to the shallow aquifer of possibly $600 \mathrm{acre}-\mathrm{ft} / \mathrm{yr}$ with consequent reduction in recharge to the intermediate and basalt aquifers that would probably not be measurable. Also about 5,600 acres of land without water rights will no longer be irrigated under 1988 OCAP regulations. The effect of this change depends on the location of that land.

Possible changes because of Public Law 101-618 include (1) removal of land from production under the water-rights acquisition program, and (2) decreases in seepage from the distribution system associated with increasing Project efficiency to 75 percent. These changes could potentially affect the hydrologic system in the Carson Desert. Many factors regarding implementation of these programs are unknown. These factors include: (1) the bench/bottom-land designation of acquired water rights, (2) where the acquired water rights will be obtained, (3) if they will be obtained in large blocks of land or scattered, individual parcels, (4) changes in the operation of the distribution system necessary to deliver the water to wetland areas, (5) the type of alternative land use in areas removed from production, and (6) concurrent changes in Project efficiency. Because hydrologic controls on surface water and ground water vary greatly in the Carson Desert and are not completely understood, the quantitative estimates of the effects of the programs are difficult to make with certainty.
West of Fallon, changes in irrigation practices that decrease seepage or the area of irrigated land have the potential to decrease recharge to the shallow, intermediate, and basalt aquifers. Near the center of the basin, changes could affect water levels in the shallow and basalt aquifers, but might have less effect on water levels in the intermediate aquifer. Near the eastern part of the basin, changes could affect water levels in the shallow aquifer but probably not in the intermediate and basalt aquifers.

Decreasing the seepage by lining canals could cause ground-water levels to decline, especially where canals are distant from ongoing irrigation. In areas where irrigation is removed, the amount of decline could be about $10 \mathrm{ft}$ at a distance of 1 to $2 \mathrm{mi}$ from lined canals.

The decline or rise of water levels in the shallow aquifer as a result of removing land from irrigation depends on whether surface-water applications have historically been greater or less than consumptive use by irrigated crops. Water levels would decline if applications historically have been greater than consumptive use and could rise temporarily if applications have been less than consumptive use. As vegetation becomes established on land removed from production, water levels would again decline to a new equilibrium.

The decline or rise of water levels as a result of removing land from irrigation also depends upon how consumptive use is supplied from the shallow aquifer. If the consumptive use historically had been supplied by ground water upgradient from fields removed from production, water levels could temporarily rise where land is removed from production or decline in areas downgradient from the change. However, if consumptive use historically had been supplied to fields by surface water applied early in the season, removing land from production might have little effect on water levels. However, decreasing the time and frequency of irrigation early in the season could cause water levels to decline.

A hypothetical example shows that if seepage from the surface-water system is decreased in proportion to the amount of land removed from production, water levels beneath about 30,000 acres of land could decline from 8 to $17 \mathrm{ft}$ if the average specific yield is 10 percent, and from 4 to $8 \mathrm{ft}$ if the average specific yield is 20 percent. The effect of water-level changes on pumped wells depends on the thickness of the near-surface zone in the shallow aquifer from which they are pumped, and the condition of the pumped well. 
Understanding of the water resources and ground-water movement in the Carson Desert can be refined by study of the extent of potable water in the intermediate and basalt aquifers, collection of waterlevel and water-quality data from the basalt and surrounding sedimentary aquifers, compilation of all available lithologic data, and study of the rates of recharge to and discharge from the basin.

Evaluation of the potential effects of changes in water use can be improved by developing maps showing the location and altitude of canals, laterals, and drains, compared with the altitude of adjacent ground-water levels. The maps could also be used to design networks for the collection of data showing the direction and rate of flow through the distribution system, the rate of surface-water application and runoff from fields, and the specific yield of aquifer materials. The effects of changes in water use can be documented by monitoring surface-water quality and flow and ground-water quality and levels as the changes take place.

\section{REFERENCES CITED}

American Geological Institute, 1976, Dictionary of geological terms: Garden City, N.J., Anchor Press/Doubleday, 472, p.

Axelrod, D.I., 1956, Mid-Pliocene floras from westcentral Nevada: University of California, Publications in Geological Sciences, v. 33, 322 p. 1957, Late Tertiary floras and the Sierra Nevadan uplift: Geological Society of America Bulletin, v. 68, no. 1, p. 19-45.

1962, Post-Pliocene uplift of the Sierra Nevada, California: Geological Society of America Bulletin, v. 73, p. 183-198.

Barnes, S.M., and Jorgenson, G.A., 1987, Report on recommended improvements for operations of the Truckee-Carson Irrigation District to increase efficiency and conserve water: SMBCE, Inc., draft report (Aug. 7), 87 p., 5 appendices.

Bates, R.L., and Jackson, J.A., eds., 1984, Dictionary of geologic terms: Garden City, N.Y., Anchor Press/Doubleday, $571 \mathrm{p}$.

1987, Glossary of Geology (3d ed.): New York, American Geological Institute, 788 p.

Bell, E.J., Fultz, L.A., and Trexler, D.T., 1984, K-Ar isotopic ages of volcanic rocks in the Reno 1 by 2 degree AMS sheet, western Nevada: Isochron/West, no. 40, p. 13-15.

Bell, J.W., 1984, Quaternary fault map of Nevada-Reno sheet: Nevada Bureau of Mines and Geology Map 79, scale 1:250,000.
Benoit, W.R., Hiner, J.E., and Forest, R.T., 1982, Discovery and geology of the Desert Peak geothermal field-A case history: Nevada Bureau of Mines and Geology Bulletin 97, $81 \mathrm{p}$.

Benson, L.V., 1978, Fluctuation in the level of pluvial Lake Lahontan during the last 40,000 years: Quaternary Research, v. 9, p. 300-318. 1991, Timing of the last high stand of Lake Lahontan: Journal of Paleolimnology, v. 5, p. 115-126.

Benson, L.V., Currey, D.R., Dorn, R.I., Lajoie, K.R., Oviatt, C.G., Robinson, S.W., Smith, G.I., and Stine, S., 1990, Chronology of expansion and contraction of four Great Basin lake systems during the past 35,000 years: Paleogeography, Paleoclimatology, and Paleoecology, v. 78, p. 241-286.

Benson, L.V., and Thompson, R.S., 1987, Lake-level variation in the Lahontan Basin for the past 50,000 years: Quaternary Research, v. 28, p. 6985.

Berger, D.L., 1992, Ground-water recharge through active sand dunes in northwestern Nevada: Water Resources Bulletin, v. 28, no. 5, p. 959-965.

Berggren, W.A., Kent, D.V., Flynn, J.J., and Van Couvering, J.A., 1985, Cenozoic geochronology: Geological Society of America Bulletin, v. 96, p. 1407-1418.

Birkeland, P.W., 1968, Correlation of Quaternary stratigraphy of the Sierra Nevada with that of the Lake Lahontan area, in Morrison, R.B., and Wright, H.E., Jr., eds., Means of correlation in Quaternary successions [7th Congress, International Association of Quaternary Research]: Salt Lake City, University of Utah Press, v. 8, p. 469500.

Broecker, W.S., and Orr, P.C., 1958, Radiocarbon chronology of Lake Lahontan and Lake Bonneville: Geological Society of America Bulletin, v. 69, p. 1009-1032.

Brown, W.M., III, Nowlin, J.O., Smith, L.H., and Flint, M.R., 1986, River-quality assessment of the Truckee and Carson River system, California, and Nevada-Hydrologic characteristics: U.S. Geological Survey Open-File Report 84-576, 201 p.

Bruce, J.L., 1981, Southern Carson Sink study area, in Trexler, D.T., Koenig, B.A., Flynn, T. Bruce, J.L., and Ghusn, G., Jr., Area specific geothermal assessment, Nevada: University of Nevada, Reno, Final Report DOE/NV/10039-3, p. 160-189.

Bureau of Land Management, 1975, Regional Environmental Analysis Record, geothermal leasing in Fort Churchill-Clan Alpine area: Carson City District, Nevada, 256 p. 
Bureau of Reclamation, [1951?], Newlands Project drain appendix: Bureau of Reclamation, $36 \mathrm{p}$. 1971, Irrigation study, Newlands Project, Nevada: Carson City, Nev., Bureau of Reclamation, Lahontan Basin Project Office, 80 p.

1986, Draft environmental impact statement for the Newlands Project proposed operating criteria and procedures: Bureau of Reclamation, 5 numbered sections, technical appendices.

1987a, Final environmental impact statement for the Newlands Project proposed operating criteria and procedures: Washington, D.C., $332 \mathrm{p}$.

1987b, Supplemental irrigation suitability land classification, final report, Newlands Project, Fallon, Nevada, Truckee and Carson Divisions: Sacramento, Calif., Water Operations and Management Branch, Irrigation Section, 75 p., 10 appendices.

1987c, Fallon Indian Reservation water quality report: Sacramento, Calif., Bureau of Reclamation, $62 \mathrm{p}$.

1989, Newlands Project water measurement, management, and conservation program-1988 annual report: Bureau of Reclamation, $41 \mathrm{p}$.

1990, Newlands Project water measurement, management, and conservation program -1989 annual report: Bureau of Reclamation, $60 \mathrm{p}$.

1992a, Initial bench and bottom land criteria, Newlands Project, Fallon, Nevada: 5 sections, 8 appendices.

-1992b, Newlands Project water measurement, management, and conservation program-1991 annual report: Bureau of Reclamation, 43 p.

1992c, Composite of irrigated project lands, Newlands Project: Provisional map, January 1992, scale 1:100,000.

Burke, D.B., and McKee, E.H., 1979, Mid-Cenozoic volcano-tectonic troughs in central Nevada: Geological Society of America Bulletin, v. 90, p. $181-184$.

Carman, R.L., (1994), Data on evapotranspiration in phyreatophyte areas, Smith Creek Valley and Carson Desert, west-central Nevada: U.S. Geological Survey Water-Resources Investigations Report 89-4118, 18 p.

CH2M Hill, 1973, Newlands Project water useimprovement study. Objective 1-Water utilization, Truckee-Carson Irrigation District: Redding, Calif., CH2M Hill preliminary report, $89 \mathrm{p}$.

1989, Fallon Indian Reservation land classification: Redding, Calif., CH2M Hill preliminary report, 89 p., 4 appendices.
1984, First quarterly report, Desert Peak Environmental Baseline Study: prepared for Phillips Geothermal Desert Peak Geothermal Project, July.

Chevron Geophysical Company, 1977, Reflection seismic survey, Soda Lake, Nevada: Salt Lake City, University of Utah Research Institute, openfile item NV/SL/CRC-5.

Chevron Resources Company, 1979a, Chevron well \#1-29-Drilling and completion history, flow test data, production record, static temp mud log, report of analysis: Salt Lake City, University of Utah Research Institute, open-file item NV/SL/CRC-9.

1979b, Test hole data for Chevron 44-5 well, Soda Lake, Nevada: Salt Lake City, University of Utah Research Institute, open-file item NV/SL/CRC-8.

1987, Environmental assessment for Soda Lake geothermal power plant project, Churchill Co., Nevada, submitted to Bureau of Land Management, Carson City, Nevada, 256 p.

Clyde-Criddle-Woodward, 1971, Report on water-use improvement study of Truckee-Carson River basin: Salt Lake City, Clyde-Criddle-Woodward report, $111 \mathrm{p}$.

1974, Report on soil and ground water studies, Newlands Project, Nevada: Salt Lake City, Clyde-Criddle-Woodward report.

Cohen, Philip, 1963, Specific yield and particle-size relations of Quaternary alluvium, Humboldt River Valley Nevada: U.S. Geological Survey WaterSupply Paper 1669-M, p. 20-23.

Conover, W.J., 1980, Practical nonparametric statistics (2d ed.): New York, John Wiley, 493 p.

Curry, R.R., 1969, Holocene climatic and glacial history of the central Sierra Nevada, California, in Schumm, S.A., and Bradley, W.C., eds., United States contributions to Quaternary research: Geological Society of America Special Paper 123, p. 1-47.

Dames \& Moore, 1988, Preliminary assessment/site inspection (PA/SI), Naval Air Station, Fallon, Nevada: Santa Barbara, Calif., Dames \& Moore report.

Davis, J.O., 1978, Quaternary tephrochronology of the Lake Lahontan area, Nevada and California: University of Nevada, Reno, Nevada Archeological Survey Research Paper 7, 137 p.

1982, The last 35,000 years in the Lahontan area, in Madsen, D.B., and O'Connell, J.F., eds., Man and environment in the Great Basin: Society for American Archeology Paper 2, p. 53-75. 
1990, Giant meanders on Humboldt River near Rye Patch, Nevada, due to catastrophic flooding (abs.): Geological Society of America Abstracts with Programs, v. 22, no. 7, p. A309.

Davis, S.N., and DeWiest, R.J., 1966, Hydrogeology: New York, John Wiley, $463 \mathrm{p}$.

Davis, J.O., Elston, R., and Townsend, G., 1986, Coastal geomorphology of the south shore of Lake Tahoe-Suggestion of an altithermal lowstand, in Elston, R., ed., Holocene environmental change in the Great Basin: Reno, University of Nevada Archeological Survey Research Paper 6, 40-65 p.

Dollarhide, W.E., 1975, Soil survey Fallon-Fernley area, [and] parts of Churchill, Lyon, Storey, and Washoe Counties: Washington, D.C., U.S. Department of Agriculture, $112 \mathrm{p}$.

Eakin, T.E., 1951, Contributions to the hydrology of eastern Nevada: Nevada State Engineer, Water Resources Bulletin 12, 171 p.

Erwin, J.W., and Berg, J.C., 1977, Bouguer gravity map of Nevada, Reno Sheet: Nevada Bureau of Mines and Geology Map 58, scale 1:250,000.

Evans, S.H., Jr., 1980, Summary of potassium/argon age dating-1979: Salt Lake City, University of Utah, Department of Geology and Geophysics Topical Report, 23 p.

Evernden, J.F., and James, G.T., 1964, Potassiumargon dates and the Tertiary floras of North America: American Journal of Science, v. 262, p. 945-974.

Frisbie, H.R., LaCamera, R.J., Riek, M.M., and Wood, D.W., 1985, Water Resources Data, Nevada, water year 1985: U.S. Geological Survey Water-Data Report NV-85-1, 255 p.

Gable, D.J., and Hatton, Tom, 1983, Maps of vertical crustal movements in the conterminous United States over the last ten million years: U.S. Geological Survey Miscellaneous Investigations Map I-1315, scale 1:5,000,000.

Gale, H.S., 1913, The search for potash in the desert basin region, in Contributions to economic geology-Part I, Metals and nonmetals except fuels: U.S. Geological Survey Bulletin 530, p. 295-311.

Garcia, K.T., Gortsema, G.C., Pennington, R.N., and Preissler, A.M., 1992, Water resources data, Nevada, water year 1991: U.S. Geological Survey Water-Data Report NV-91-1, 481 p.

Garside, L.J., Hess, R.H., Fleming, C.L., and Weimer, B.P., 1988, Oil and gas development in Nevada: Nevada Bureau of Mines and Geology Bulletin $104,136 \mathrm{p}$.
Garside, L.J., and Schilling, J.H., 1979, Thermal waters of Nevada: Nevada Bureau of Mines and Geology Bulletin 91, 163 p.

Geothermal Resources Council, 1985, The state scene in Nevada: Geothermal Resources Council Bulletin, v. 14, no. 11, p. 18.

Glancy, P.A., 1986, Geohydrology of the basalt and unconsolidated sedimentary aquifers in the Fallon area, Churchill County, Nevada: U.S. Geological Survey Water-Supply Paper 2263, 62 p.

Glancy, P.A., and Katzer, T.L., 1975, Water-resources appraisal of the Carson River Basin, western Nevada, Nevada and California: Nevada Division of Water Resources, Reconnaissance Report 59, $126 \mathrm{p}$.

Glancy, P.A., and Rush, F.E., 1968, Water-resources appraisal of Smoke Creek-San Emidio Desert area, Nevada and California: Nevada Department of Conservation and Natural Resources, Water Resources-Reconnaissance Report 44, 57 p.

Green, R.G., Gallagher, J.E., and Bianchi, M.W., 1976, Water distribution on the Newlands project, Nevada: Bureau of Reclamation, Lahontan Basin Projects Office, $17 \mathrm{p}$.

Greene, R.C., Stewart, J.H., John, D.A., Hardyman, R.F., Silberling, N.J., and Sorensen, M.L., 1991, Geologic map of the Reno 1 degree by 2 degree quadrangle, Nevada and California: U.S. Geological Survey Miscellaneous Field Studies Map MF-2154-A, scale 1:250,000.

Guitjens, J.C., and Mahannah, C.N., 1973, Newlands Project water study, water year 1972: University of Nevada, Reno, Cooperative Extension Service Report 97, $11 \mathrm{p}$.

Guitjens, J.C., and Mahannah, C.N., 1976, Newlands Project water study, summary: University of Nevada, Reno, Cooperative Extension Service Bulletin 40, 12 p.

Hallock, R.J., and Hallock, L.L., eds., 1993, Detailed study of irrigation drainage in and near wildlife management areas, west-central Nevada, 1987-90. Part B-Effect on biota in Stillwater and Fernley Wildlife Management Areas and other nearby wetlands: U.S. Geological Survey, Water-Resources Investigations Report 92-4024B, 84 p.

Harrill, J.R., 1973, Evaluation of the water resources of Lemmon Valley, Washoe County, Nevada, with emphasis on effects of ground-water development to 1971: Nevada Department of Conservation and Natural Resources Bulletin 42, $130 \mathrm{p}$.

Harris, E.E., 1970, Reconnaissance bathymetry of Pyramid Lake, Washoe County, Nevada: U.S. Geological Survey Hydrologic Investigations Atlas HA-379, 1:62,500. 
Hastings, D.D., 1979, Results of exploratory drilling, northern Fallon basin, western Nevada, in Newman, G.W., and Goode, H.D., eds., Basin and Range Symposium and Great Basin Field Conference: Denver, Colo., Rocky Mountain Association of Geologists and Utah Geological Association, p. 513-522.

Hess, D.L., Mello, K.A., Sexton, R.J., and Young, R.L., 1993, Water-resources data, Nevada, water year 1992: U.S. Geological Survey Water-Data Report NV-92-1, 511 p.

Hill, D.G., 1979, Intermediate depth geothermal temperature study, gradient holes $11-33$ and 6333, Soda Lake, NV: Salt Lake City, University of Utah Research Institute open-file item NV/SL/CRC-10, 37 p..

Hillel, Daniel, 1980, Applications of soil physics: New York, Academic Press, 385 p.

Hoffman, R.J., in press, Detailed study of irrigation drainage in and near wildlife management areas, west-central Nevada, 1987-90. Part C-Summary of irrigation-drainage effects on water quality, bottom sediment, and biota: U.S. Geological Survey Water-Resources Investigations Report 92-4024C.

Hoffman, R.J., Hallock, R.J., Rowe, T.G., Lico, M.S., Burge, H.L., and Thompson, S.P., 1990, Reconnaissance investigation of water quality, bottom sediment, and biota associated with irrigation drainage in and near Stillwater Wildlife Management Area, Churchill County, Nevada, 1986-87: U.S. Geological Survey Water-Resources Investigations Report 89-4105, $150 \mathrm{p}$.

Hollander, Miles, and Wolfe, D.A., 1973, Nonparametric statistical methods: New York, John Wiley, $503 \mathrm{p}$.

Holmes, Arthur, 1960, A revised geological time scale: Edinburgh Geological Society Transactions, v. 17 , p. $183-216$.

Horton, R.C., 1978, Lithologic log and interpretation of instrument logs, NURE project, Carson Sink, Nevada, borehole: Bendix Field Engineering Corporation, GJBX-53(78), $36 \mathrm{p}$.

Huber, N.K., 1981, Amount and timing of late Cenozoic uplift and tilt of the central Sierra Nevada, California-Evidence from the Upper San Joaquin River basin: U.S. Geological Society Professional Paper 1197, 28 p.

Iman, R.L., and Conover, W.J., 1983, A modern approach to statistics: New York, John Wiley, 497 p.
Jacob, C.E., 1963, Correction of drawdowns caused by a pumped well tapping less than the full thickness of an aquifer, in Bentall, Ray, compiler, Methods of determining permeability, transmissibility, and drawdown: U.S. Geological Survey Water-Supply Paper 1536-I, p. 272-292.

Johnson, A.G., 1988, Statistics: San Diego, Harcourt Brace Jovanovich, $433 \mathrm{p}$

Johnson, M.G., 1977, Geology and mineral deposits of Pershing County, Nevada: Nevada Bureau of Mines and Geology Bulletin 89, 115 p.

Jones, J.C., 1933, Itinerary, Reno to Pyramid Lake and return, in Jenkins, O.P., ed., Guidebook 16, Excursion C-1, Middle California and western Nevada: Washington D.C., XVI International Geological Congress, p. 102-108.

Katzenstein, A.M., and Bjornstad, S.C., 1987, Geothermal resource evaluation at Naval Air Station, Fallon, Nevada: China Lake, Calif., Naval Weapons Center, NWC TP 6808, 53 p.

Kendall, M.B., 1975, Rank correlation methods (4th ed.): London, Charles Griffin, 202 p.

King, Clarence, 1878, Systematic geology: U.S. Geological Exploration, 40th Parallel, v. 1, 803 p.

Kulp, J.L., 1961, Geological time scale: Science, v. 133 , p. $1105-1114$.

Lao, Yong, and Benson, L.V., 1988, Uranium-series age estimates and paleoclimatic significance of Pleistocene tufas from the Lahontan Basin, California and Nevada: Quaternary Research, v. 30, p. 165-176.

Lee, C.H., and Clark, W.O., 1916, Report on Soda Lakes investigation, Truckee-Carson Project, near Fallon, Nevada: U.S. Geological Survey report, p. 656-706.

Lico, M.S., 1992, Detailed study of irrigation drainage in and near wildlife management areas, westcentral Nevada, 1987-90. Part A-Water quality, sediment composition and hydrogeochemical processes in stillwater and Fernley Wildlife Management Areas: U.S. Geological Survey Water-Resources Investigations Report 92-4024A, $65 \mathrm{p}$.

Lico, M.S., Welch, A.H., and Hughes, J.L., 1986, Hydrologic, lithologic, and chemical data for sediments in the shallow aquifer at two sites near Fallon, Churchill County, Nevada, 1984-85: U.S. Geological Survey Open-File Report 86-250, $43 \mathrm{p}$. 
Lico, M.S., Welch, A.H., and Hughes, J.L., 1987, Geochemistry of ground water in the shallow alluvial aquifer, Carson Desert, western Nevada, in Averett, R.C., and McKnight, D.M., eds., Chemical quality of water and the hydrologic cycle: Chelsea, Mich., Lewis Publishers, p. 89109.

Locke, A., Billingsley, P.R., and Mayo, E.B., 1940, Sierra Nevada tectonic patterns: Geological Society of America Bulletin, v. 51, p. 513-540.

Lohman, S.W., 1972, Ground-water hydraulics: U.S. Geological Survey Professional Paper 708, 70 p.

Lohman, S.W., and others, 1972, Definitions of selected ground-water terms-Revisions and conceptual refinements: U.S. Geological Survey Water-Supply Paper 1988, 21 p.

Lyford, G.R., and Townsend, M.A., 1985, Review of the proposed and historical bench and bottom land designations in the Newlands Project, Fallon, Nevada: Sacramento, Calif., Bureau of Reclamation, $78 \mathrm{p}$.

MacDiarmid, T.R., 1988, An economic analysis of the efficiency target policy for the Carson Division of the Newlands Project: University of Nevada, Reno, M.S. Thesis, 122 p.

Mahannah, C.N., Guitjens, J.C., and York, C.R., 1975, Western Nevada water controversy: University of Nevada Reno, Max C. Fleischmann College of Agriculture Report 29$\mathrm{UN} 3 \mathrm{~A} / 5: 34,27 \mathrm{p}$.

Marston, K.L., 1989, Alfalfa yield response to shallow groundwater in Fallon, Nevada: University of Nevada, Reno, unpublished M.S. Thesis, $90 \mathrm{p}$.

Melhorn, W.N., [1974?], Analysis of the StandardAmoco S.P. Land Co. Well \#1 (Carson Sink), Churchill County, Nevada: Available at the Nevada Bureau of Mines and Geology oil and gas files, $7 \mathrm{p}$., with summary $\log$ and deviation record.

Mifflin, M.D., and Wheat, M.M., 1971, Isostatic rebound in the Lahontan basin, northwestern Great Basin (abs.): Geological Society of America Abstracts with Programs, p. 647.

1979, Pluvial lakes and estimated pluvial climates of Nevada: Nevada Bureau of Mines and Geology Bulletin 94, 57 p.

Morgan, D.S., 1982, Hydrogeology of the Stillwater geothermal area, Churchill County, Nevada: U.S. Geological Survey Open-File Report 82$345,95 \mathrm{p}$.

Morrison, R.B., 1959, Stratigraphic sections, well logs, and soil-profile sections in the southern Carson Desert, near Fallon, Nevada: U.S. Geological Survey Open-File Report, 160 p.
1964, Lake Lahontan-Geology of southern Carson Desert, Nevada: U.S. Geological Survey Professional Paper 401, 156 p.

-1991, Quaternary stratigraphic, hydrologic, and climatic history of the Great Basin, with emphasis on Lakes Lahontan, Bonneville, and Tecopa, in Morrison, R.B., ed., The Geology of North America, Quaternary Nonglacial Geology-Conterminous U.S.: Geological Society of America, v. K2, p. 283-320.

Morrison, R.B., and Davis, J.O., 1984a, Quaternary stratigraphy and archeoogy of the Lake Lahontan area-A re-assessment, in Lintz, Joseph, Jr., ed., Western geological excursions: University of Nevada, Reno, Mackay School of Mines, v. 1, p. 252-281.

-1984b, Supplemental guidebook for Geological Society of America field trip 13, Quatenary stratigraphy and archeology of the Lake Lahontan area-A re-assessment: University of Nevada, Desert Research Institute Technical Report 42041, $50 \mathrm{p}$.

Morrison, R.B., and Frye, J.C., 1965, Correlation of the Quarternary successions of the Lake Lahontan, Lake Bonneville, Rocky Mountain, southern Great Plains, and eastern Midwest areas: Nevada Bureau of Mines Report 9, 45 p.

National Oceanic and Atmospheric Administration, 1986, Climatological data, Annual summary, Nevada, 1986: v. 101, no. 13.

National Oceanic and Atmospheric Administration, 1990, Climatological data, annual summary, Nevada 1990: v. 105 , no. 12.

Nevada Bureau of Consumer health Protection Services, 1980, Water supply regulations-Part 1, water-quality standards-Monitoring, recordkeeping, and reporting: Nevada Division of Health, 16 p., appendix A, 11 p.

Nevada Division of Water Resources, 1971, Average annual precipitation, in Hydrologic Atlas Map S-3: Nevada Division of Water Resources, Water for Nevada Series.

Olmsted, F.H., 1985, Ground-water discharge and recharge in the Soda Lake and Upsal Hogback geothermal areas, Churchill County, Nevada: U.S. Geological Survey Water-Resources Investigations Report 85-4033, 27 p.

Olmsted, F.H., Glancy, P.A., Harrill, J.R., Rush, F.E., and Van Denburgh, A.S., 1975, Preliminary hydrogeologic appraisal of selected hydrothermal systems in northern and central Nevada: U.S. Geological Survey Open-File Report 75-56, $267 \mathrm{p}$. 
Olmsted, F.H., Welch, A.H., Van Denburgh, A.S., and Ingebritsen, S.E., 1984, Geohydrology, aqueous geochemistry, and thermal regime of the Soda Lakes and Upsal Hogback geothermal systems, Churchill County, Nevada: U.S. Geological Survey Water-Resources Investigations Report 84-4054, 166 p.

Page, B.M., 1965, Preliminary geologic map of a part of the Stillwater Range, Churchill County, Nevada: Nevada Bureau of Mines and Geology Map 28, scale 1:125,000.

Pahl, Randy, 1992, Lahontan Valley wetlands water rights acquisition evaluation of 1972-91 data: Nevada Division of Water Planning, $4 \mathrm{p}$.

Phillips Petroleum Company, 1973, Ground magnetics and gravity maps, Carson Sink area, Desert Peak, Nevada: Salt Lake City, University of Utah Research Institute, open-file item NV/DP/PPC-2, 4 maps.

Pupacko, Alex, LaCamera, R.J., Riek, M.M., and Wood, D.B., 1988, Water resources data, Nevada, water year 1986: U.S. Geological Survey Water-Data Report NV-86-1, 263 p.

Reading, H.G., ed., 1979, Sedimentary environments and facies: New York, Elsevier, 557 p.

Reynolds, C.B., and associates, 1975, Reflection seismic survey of the Soda Lake area, Nevada (24 line miles) done for Chevron: Salt Lake City, University of Utah Research Institute, open-file item NV/SL/CRC-4, 4 p.

Rollins, M.B., 1965, Water quality of the Newlands Reclamation Project: Reno, Nev., U.S. Department of Agriculture, Agricultural Research Service, $44 \mathrm{p}$.

Rowan, L.C., and Wetlaufer, P.H., 1973, Structural analysis of Nevada using ERTS-1 images-A preliminary report: Symposium of significant results obtained from ERTS-1, March 5-9, 1973, NASA/Goddard Space Flight Center, p. 413-423.

Rowe, T.G., and Hoffman, R.J., 1990, Wildlife kills in the Carson Sink, western Nevada, winter 1986-87, in Carr, J.E., Chase, E.B., Paulsin, R.W., and Moody, D.W., compilers, National water summary 1987-Hydrologic events and water supply and use: U.S. Geological Survey Water-Supply Paper 2350, p. 37-40.

Rowe, T.G., Lico, M.S., Hallock, R.J., Maest, A.S., and Hoffman, R.J., 1991, Physical, chemical, and biological data for detailed study of irrigation drainage in and near Stillwater, Fernley, and Humboldt Wildlife Management Areas and Carson Lake, west-central Nevada, 1987-89: U.S. Geological Survey Open-File Report 91-185, $199 \mathrm{p}$.
Rush, F.E., 1968, Index of hydrographic areas in Nevada: Nevada Division of Water Resources Information Report 6, 38 p.

-1974, Static ground water levels of Nevada: Nevada Division of Water Resources Map, scale 1:750,000.

Ryall, A.S., 1977, Earthquake hazard in the Nevada region: Seismological Society of America Bulletin, v. 67, no. 2, p. 517-532.

Sarna-Wojcicki, A.M., and Davis, J.O., 1991, Quaternary tephrochronology, in Morrison, R.B., ed., Quaternary nonglacial geology-Conterminous U.S.: The Geology of North America, Geological Society of America, v. K-2, p. 93-116.

Sarna-Wojcicki, A.M., Lajoie, K.R., Meyer, C.E., Adam, D.P., and Rieck, H.J., 1991, Tephrochronological correlation of upper Neogene sediments along the Pacific margin, conterminous United States, in Morrison, R.B., ed., Quaternary nonglacial geology-Conterminous U.S.: The geology of North America, Geological Society of America, v. K-2, p. 117-140.

Schertz, T.L., Alexander, R.B., and Ohe, D.J., 1991, The computer program EStimate Trend, a system for detection of trends in water-quality data: U.S. Geological Survey Water-Resources Investigations Report 91-4040, 63 p.

Seiler, R.L., and Allander, K.K., 1993, Water-level changes and directions of ground-water movement in the shallow aquifer, Fallon area, Churchill County, Nevada: U.S. Geological Survey WaterResources Investigations Report 93-4118, 74 p.

Sertic, Kathy, Zimmermann, Doug, and Gross, Dan, 1988, Reconnaissance survey of ground-water quality in the Carson River basin: Nevada Division of Environmental Protection Report, 60 p.

Sibbett, B.S., 1979, Geology of the Soda Lake geothermal area: Salt Lake City, University of Utah Research Institute, Report DOE/ET/28392-34, $27 \mathrm{p}$.

Sibbett, B.S., and Blackett, R.E., 1982, Lithologic interpretation of the DeBraga \#2 and Richard Weishaupt \#1 geothermal wells, Stillwater project, Churchill County, Nevada: Salt Lake City, University of Utah Research Institute, Report DOE/ID/12079-57, $10 \mathrm{p}$.

Speed, R.C., 1966, Time and geometry of Mesozoic orogeny, Dixie Valley-Carson Sink region, Nevada, Geological Society of America (abs.): Special Paper 101, p. 336-337.

Stabler, Herman, 1904, Report on ground waters of Carson Sink: U.S. Geological Survey Reclamation Service, 49 p. 
Stephens, D.B., and Knowlton, R., Jr., 1986, Soil water movement and recharge through sand at a semiarid site in New Mexico: Water Resources Research. v. 22, no. 6, p. 881-889.

Stewart, J.H., 1978, Basin-range structure in western North America-A review, in Smith, R.B., and Eaton, G.P., eds., Cenozoic tectonics and regional geophysics of the western Cordillera: Geological Society of America Memoir 152, p. 1-31. -1980, Geology of Nevada-A discussion to accompany the geologic map of Nevada: Nevada Bureau of Mines and Geology Special Publication 4, $136 \mathrm{p}$.

Tabaei, H.A., 1991, Water quality of shallow groundwater reused for irrigation: M.S. Thesis, University of Nevada, Reno, 83 p.

Thompson, R.S., Benson, L.V., and Hattori, E.M., 1986, A revised chronology for the last Pleistocene lake cycle in the central Lahontan basin: Quaternary Research, v. 25, no. 1, p. 1-9.

Tidball, R.R., Wilson, S.A., and Cappellucci, Anthony J., 1991, The composition of soils, plants, and waters in the TJ drain catchment area, Newlands Irrigation Project, Churchill County, Nevada: U.S. Geological Survey Open-File Report 91$371,81 \mathrm{p}$.

Tokunaga, Tetsu, and Benson, S.M., 1991, Evaluation of management options for disposal of salt and trace element laden agricultural drainage water from the Fallon Indian Reservation, Fallon, Nevada: Berkeley, University of California, Lawrence Berkeley Laboratory Final Report LBL-30473, 62 p.

Tokunga, Tetsu, Benson, S.M., and Yee, A., 1990, Evaluation of options for disposal of TJ drainage water, Stillwater, Nevada, progress report 1: Berkeley, University of California, Lawrence Berkeley Laboratory, LBID-1607, 54 p.

Tovey, Rhys, 1963, Consumptive use and yield of alfalfa grown in the presence of static water tables: University of Nevada, Reno, Agricultural Experiment Station Bulletin 232, $44 \mathrm{p}$.

Trescott, P.C., Pinder, G.F., and Larson, S.P., 1976, Finite-difference model for aquifer simulations in two dimensions with results of numerical experiments: U.S. Geological Survey Techniques of Water-Resources Investigations, Book 7, Chapter C1, $16 \mathrm{p}$.

Tukey, J.W., 1977, Exploratory data analysis: Menlo Park, Calif., Addison-Wesley Publishing Co., $688 \mathrm{p}$.

Tuteur, L.F., 1976, Alfalfa water use as determined by lysimeters at Fallon, Nevada: University of Nevada, Reno, M.S. Thesis, 71 p.
Union Oil Company of California, 1981, Technical report, well Richard Weishaupt No. 1, Stillwater prospect, Churchill County, Nevada: Salt Lake City, University of Utah Research Institute, openfile item NV/STR/UOC-4, 64 p.

Union 76 Geothermal Division, [1979?], Technical report on DeBraga no. 2, Churchill County, Nevada: Salt Lake City, University of Utah openfile item NV/STR/UOC-2, 10 chap.

U.S. Department of the Interior, Draft environmental statement of the proposed operating criteria for the Lower Truckee-Lower Carson River Basins: Reno, Nev., Special Projects Office, 9 sections, 11 appendices.

1988, Final operating criteria and procedures, record of decision, Newlands Project, NevadaCalifornia: Washington, D.C., 1988, 22 p., 5 numbered appendices.

U.S. Environmental Protection Agency, 1976, Quality criteria for water: Washington D.C., $256 \mathrm{p}$.

1986a, Maximum contaminant levels (subpart B of part 141, National Interim Primary DrinkingWater Regulations): U.S. Code of Federal Regulations, Title 40 , Parts 100 to 149 , revised July 1 , 1986, p. $524-528$.

1986b, Water pollution control; national primary drinking water regulations; radionuclides; advanced notice of proposed rulemaking: Federal Register, v. 51 , no. 189 , p. $34836-34862$.

1986c, Secondary maximum contaminent levels (section 143.3, of part 143, National secondary drinking-water regulations): U.S. Code of Federal Regulations, Title 40, parts 100 to 149, revised as of July 1,1986, p. 587-590.

U.S. Fish and Wildlife Service, 1992, Scoping report, proposed water acquisition program for Lahontan Valley wetlands under Public Law 101-618: Portland, Oreg., U.S. Fish and Wildlife Service Report, $24 \mathrm{p}$.

U.S. Geological Survey, 1968-75, Water-resources data for Nevada, 1967-74: U.S. Geological Survey water-data reports (published annually).

1976, Land use report, Reno sheet: U.S. Geological Survey Open-File Report 76-123-1, scale $1: 250,000$.

1976-93, Water resources data, Nevada, water years 1975-92: U.S. Geological Survey WaterData Reports NV-75-1 to NV-92-1 (published annually).

1986, National water summary 1985Hydrologic events and surface-water resources: U.S. Geological Survey Water-Supply Paper 2300, $506 \mathrm{p}$. 
Van Denburgh, A.S., and Arteaga, F.E., 1985, Revised water budget for the Fernley area, westcentral Nevada, 1979: U.S. Geological Survey Open-File Report 84-712, 17 p.

Welch, A.H., and Lico, M.S., 1988, Aqueous geochemistry of ground water with high concentrations of arsenic and uranium, Carson River Basin, Nevada (abs.): Chemical Geology, v. 70, no. $1 / 2$, p. 19.

Welch, A.H., and Plume, R.W., 1987, Water-quality assessment of the Carson River ground-water basin, Nevada and California-Project description: U.S. Geological Survey Open-File Report 87-104, $27 \mathrm{p}$.

Welch, A.H., Plume, R.W., Frick, E.A., and Hughes, J.L., 1989, Ground-water-quality assessment of the Carson River basin, Nevada and California-Analysis of available water-quality data through 1987: U.S. Geological Survey Open-File Report 89-382, 115 p.
Westec Services, 1987, Soda Lake geothermal injection well and waste discharge permit application and supplemental information: Ventura, Calif., Westec Services report, 3 sections and appendix.

Whitney, Rita, in press, Data on ground-water quality in the Carson River Basin, western Nevada and Eastern California, 1987-90: U.S. Geological Survey Open-File Report 94-39.

Willden, Ronald, and Speed, R.C., 1974, Geology and mineral deposits of Churchill County, Nevada: Nevada Bureau of Mines and Geology Bulletin $83,95 \mathrm{p}$.

Winograd, I.J., Szabo, B.J., Coplen, T.B., Riggs, A.C., and Kolesar, P.T., 1985, Two-million-year record of deuterium depletion in Great Basin ground waters: Science, v. 227, p. 519-522.

Yardas, David, and Robertson, David, 1991, BelowLahontan Reservoir model, documentation and user guide, version 3.2: Environmental Defense Fund, 7 sections, 3 appendices. 
